\title{
Consequences of rainforest conversion to smallholder rubber and oil palm plantations on soil trace gas fluxes from highly weathered soils in Sumatra, Indonesia
}

\author{
Dissertation zur Erlangung des Doktorgrades \\ der Fakultät für Forstwissenschaften und Waldökologie \\ der Georg-August-Universität Göttingen \\ vorgelegt von \\ Evelyn Hassler \\ geboren in Freiburg im Breisgau
}

Göttingen, Oktober 2016 
1. Gutachter: Prof. Dr. Edzo Veldkamp

2. Gutachter: Prof. Dr. Alexander Knohl

Betreuer: Prof. Dr. Edzo Veldkamp \& Dr. Marife D. Corre

Abteilung Ökopedologie der Tropen und Subtropen,

Georg-August-Universität Göttingen

Tag der mündlichen Prüfung: 20. Dezember 2016

Prüfer: Prof. Dr. Edzo Veldkamp, Prof. Dr. Alexander Knohl, Dr. Marife D. Corre 


\section{Table of Contents}

$\begin{array}{ll}\text { Summary } & 5\end{array}$

$\begin{array}{ll}\text { Zusammenfassung } & 7\end{array}$

$\begin{array}{ll}\text { Chapter 1. General Introduction } & 10\end{array}$

$\begin{array}{ll}\text { 1.1 Land-use change in Sumatra, Indonesia } & 10\end{array}$

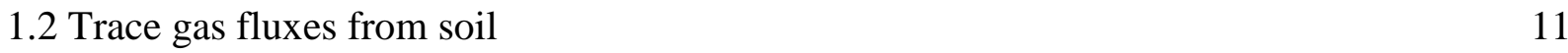

1.3 Land-use change effects on soil trace gas fluxes 12

1.4 The EEFForTs project 13

1.5 Aims and hypotheses 14

Chapter 2. Soil fertility controls soil-atmosphere carbon dioxide and methane fluxes in a tropical landscape converted from lowland forest to rubber and oil palm plantations

$\begin{array}{ll}2.1 \text { Introduction } & 24\end{array}$

2.2 Material and methods 28

$\begin{array}{ll}2.3 \text { Results } & 34\end{array}$

2.4 Discussion

2.5 Consequences of land-use change for soil trace gas fluxes $\quad 50$

$\begin{array}{ll}\text { Appendix } & 52\end{array}$

Chapter 3. Soil nitrogen oxide fluxes from lowland forests converted to smallholder rubber and oil palm plantations in Sumatra, Indonesia $\quad 64$

$\begin{array}{ll}3.1 \text { Introduction } & 65\end{array}$

3.2 Material and methods $\quad 67$ 
$\begin{array}{ll}3.4 \text { Discussion } & 83\end{array}$

$\begin{array}{ll}3.5 \text { Conclusions } & 89\end{array}$

$\begin{array}{ll}\text { Appendix } & 92\end{array}$

Chapter 4. Canopy soil of oil palm plantations emits methane $\begin{array}{ll}\text { and nitrous oxide } & 100\end{array}$

$\begin{array}{ll}4.1 \text { Introduction } & 101\end{array}$

4.2 Material and methods 103

$\begin{array}{ll}4.3 \text { Results } & 109\end{array}$

$\begin{array}{ll}\text { 4.4 Discussion } & 111\end{array}$

4.5 Relevance of canopy soil $\mathrm{N}_{2} \mathrm{O}$ and $\mathrm{CH}_{4}$ fluxes 113

$\begin{array}{ll}\text { Chapter 5. Synthesis } & 121\end{array}$

5.1 Key findings of this thesis $\quad 121$

5.2 Implications for the carbon budget $\quad 122$

$\begin{array}{ll}5.3 \text { Implications for the nitrogen budget } & 127\end{array}$

$\begin{array}{ll}\text { Danksagung } & 134\end{array}$

$\begin{array}{ll}\text { Curriculum Vitae } & 135\end{array}$ 


\section{Summary}

In Sumatra, Indonesia, the establishment of oil palm and rubber plantations is widespread. However, it occurs at the expense of forest area. Since global demand for palm oil and rubber is increasing, forest conversion is expected to continue. Furthermore, studies have shown that forest destruction and the establishment of agricultural land uses influence the soil-atmosphere exchange of the climate-relevant trace gases carbon dioxide $\left(\mathrm{CO}_{2}\right)$, methane $\left(\mathrm{CH}_{4}\right)$, nitrous oxide $\left(\mathrm{N}_{2} \mathrm{O}\right)$ and nitric oxide $(\mathrm{NO})$. Nevertheless, trace gas measurements from oil palm and rubber plantations are scarce. Additionally, researchers have so far not considered oil palm canopy soils as a possible source or sink of trace gases. The present thesis consists of three studies, which assess the impact of forest conversion into smallholder oil palm and rubber plantations on soil $\mathrm{CO}_{2}$ and $\mathrm{CH}_{4}$ fluxes, as well as on soil $\mathrm{N}_{2} \mathrm{O}$ and $\mathrm{NO}$ fluxes, and which investigate the importance of oil palm canopy soil for $\mathrm{N}_{2} \mathrm{O}$ and $\mathrm{CH}_{4}$ fluxes. We conducted the studies on highly weathered tropical soils in Jambi Province, Sumatra, Indonesia and selected two soil landscapes which mainly differ in texture (clay and loam Acrisol). To examine the impact of land-use change on soil trace gas fluxes we investigated four different land uses per landscape: lowland forest and jungle rubber (rubber trees interspersed in secondary forest), as reference land uses, as well as smallholder rubber (7-17 years old) and oil palm plantations (9-16 years old), as converted land uses. Each land use was replicated four times in both landscapes.

The first study investigated changes in soil $\mathrm{CO}_{2}$ and $\mathrm{CH}_{4}$ fluxes with forest conversion to smallholder oil palm and rubber plantations. We determined soil $\mathrm{CO}_{2}$ and $\mathrm{CH}_{4}$ fluxes monthly from December 2012 to December 2013, using static vented chambers. Our findings show that soil $\mathrm{CO}_{2}$ fluxes in oil palm plantations were reduced and that fluxes from the other three land uses were comparable among each other in both landscapes. We attributed this decrease to strongly decomposed soil organic matter, reduced soil carbon (C) stocks as well as to phosphorus fertilization and liming, which led to a lower $\mathrm{C}$ allocation to roots. Due to reduced nitrogen $(\mathrm{N})$ availability in the converted land uses $\mathrm{CH}_{4}$ uptake was lower in oil palm and rubber when compared to the reference land uses in both landscapes. Thus, soil fertility appeared to be an important controller of soil $\mathrm{CO}_{2}$ and $\mathrm{CH}_{4}$ fluxes in this tropical landscape.

The second study focused on the impact of forest conversion into smallholder oil palm and rubber plantations on soil $\mathrm{N}_{2} \mathrm{O}$ and $\mathrm{NO}$ fluxes. Additionally, we compared soil $\mathrm{N}_{2} \mathrm{O}$ fluxes 
from smallholder oil palm plantations with fluxes from a large-scale oil palm plantation. We determined soil $\mathrm{N}_{2} \mathrm{O}$ fluxes monthly from December 2012 to December 2013 in the two landscapes and weekly to bi-weekly from July 2014 to July 2015 in the large-scale oil palm plantation, using static vented chambers. Using open dynamic chambers, we measured soil NO fluxes four times in all land uses of both landscapes between March and September 2013. Our results show that land-use change did not affect soil $\mathrm{N}_{2} \mathrm{O}$ and $\mathrm{NO}$ fluxes because of low initial $\mathrm{N}$ availability in the reference land uses, so that $\mathrm{N}_{2} \mathrm{O}$ and $\mathrm{NO}$ fluxes were also low, and any changes due to conversion might have been too small to identify. However, the large-scale oil palm plantation, although not significantly different, showed, because of their higher fertilizer input, on average 3.5 times higher soil $\mathrm{N}_{2} \mathrm{O}$ fluxes than the smallholder oil palm plantations.

The aim of the third study was to quantify $\mathrm{N}_{2} \mathrm{O}$ and $\mathrm{CH}_{4}$ fluxes from oil palm canopy soils. We measured soil $\mathrm{N}_{2} \mathrm{O}$ and $\mathrm{CH}_{4}$ from three different stem heights in eight smallholder oil palm plantations across the two landscapes from February 2013 to May 2014, on a bi-weekly to monthly basis, using in-situ incubation. Oil palm canopy soil emitted $\mathrm{N}_{2} \mathrm{O}$ and $\mathrm{CH}_{4}$ from all stem heights. However, fluxes were low compared to ground soil fluxes. This was due to a low amount of canopy soil on a hectare basis and due to high nitrate contents, which might have suppressed $\mathrm{CH}_{4}$ production.

In the synthesis of this dissertation, data on soil trace gas fluxes were embedded into a broader context to gain information on changes of the net biome exchange (NBE) and on partial $\mathrm{N}$ budgets with land-use change. Soil $\mathrm{CO}_{2}$ and $\mathrm{CH}_{4}$ fluxes were combined with an ancillary study on net primary production and harvest as well as with estimations on the contribution of heterotrophic soil respiration to total soil respiration. Soil $\mathrm{N}_{2} \mathrm{O}$ and $\mathrm{NO}$ fluxes were combined with ancillary studies on $\mathrm{N}$ inputs and outputs via fertilization, bulk precipitation, leaching and harvest. The results revealed that the NBE of oil palm plantations was higher compared to forest. Nevertheless, implications for climate change are negative since forest conversion itself results in a huge $\mathrm{C}$ loss, which cannot be compensated over time by oil palm plantations. The lowest partial $\mathrm{N}$ budget was detected in oil palm, indicating that $\mathrm{N}$ inputs via precipitation and fertilization were smaller than the huge $\mathrm{N}$ loss via harvest. Overall, these results illustrate that land-use change has negative effects on the $\mathrm{C}$ and $\mathrm{N}$ budgets of tropical ecosystems. 


\section{Zusammenfassung}

In Sumatra, Indonesien, ist der Anbau von Palmöl- und Kautschukplantagen weit verbreitet und geschieht auf Kosten des Regenwaldes. Da die Nachfrage für Palmöl und Kautschuk wächst, ist davon auszugehen, dass dieser Trend anhalten wird. Bekanntermaßen beeinflussen Waldzerstörung und darauf folgende landwirtschaftliche Nutzung den Gasaustausch der klimarelevanten Spurengase Kohlenstoffdioxid $\left(\mathrm{CO}_{2}\right)$, Methan $\left(\mathrm{CH}_{4}\right)$, Distickstoffoxid $\left(\mathrm{N}_{2} \mathrm{O}\right)$ und Stickstoffmonoxid (NO) zwischen dem Boden und der Atmosphäre. Dennoch wurden bisher nur wenig Messungen von Spurengasflüssen in Palmöl- und Kautschukplantagen durchgeführt. Auch Ölpalm-Kronendachböden, welche potenzielle Spurengasquellen bzw. -senken darstellen, sind bisher gänzlich unbeachtet geblieben. Die vorliegende Dissertation stellt drei Studien vor, welche den Einfluss von Regenwaldumwandlung in kleinbäuerliche Palmöl- und Kautschukplantagen auf $\mathrm{CO}_{2}$ - und $\mathrm{CH}_{4}$-Flüsse, sowie auf $\mathrm{N}_{2} \mathrm{O}$ - und NO-Flüsse des Bodens diskutieren und die Bedeutung von Ölpalm-Kronendachböden für $\mathrm{N}_{2} \mathrm{O}$ - und $\mathrm{CH}_{4}$-Flüsse untersuchen. Die Studien wurden auf intensiv verwitterten tropischen Böden in der Provinz Jambi (Sumatra, Indonesien) durchgeführt. Zwei Bodenlandschaften, welche sich hauptsächlich in ihrer Bodentextur unterscheiden, wurden ausgewählt (lehm- bzw. tonhaltiger Acrisol) und jeweils vier Landnutzungen untersucht: Tieflandregenwald und Sekundärwald durchsetzt mit Kautschukbäumen, welche als Referenzflächen dienten, und kleinbäuerliche Kautschuk- (7-17 Jahre alt) und Palmölplantagen (9-16 Jahre alt), welche die umgewandelten Landnutzungen darstellen. Jede Landnutzung innerhalb beider Landschaften wurde durch vier Replikate repräsentiert.

Die erste Studie untersucht Veränderungen von $\mathrm{CO}_{2}$ - und $\mathrm{CH}_{4}$-Flüssen des Bodens, welche mit der Umwandlung von Regenwald $\mathrm{zu}$ kleinbäuerlichen Palmöl- und Kautschukplantagen einhergehen. Diese Flüsse wurden monatlich von Dezember 2012 bis Dezember 2013 mit Hilfe von belüfteten statischen Hauben bestimmt. Unsere Ergebnisse zeigen, dass die $\mathrm{CO}_{2}$-Flüsse in beiden Landschaften innerhalb der Palmölplantagen vermindert, sowie vergleichbar zwischen den anderen drei Landnutzungen waren. Dies lag sowohl an intensiv zersetztem organischem Material und reduzierten Kohlenstoffbeständen des Bodens als auch an

Phosphor-Düngung und Kalkung (was wiederum $\mathrm{zu}$ einer geringeren Bereitstellung von Kohlenstoff zu den Pflanzenwurzeln geführt hat). Aufgrund einer geringeren 
Stickstoffverfügbarkeit in den Palmöl- und Kautschukplantagen war die $\mathrm{CH}_{4}$-Aufnahme des Bodens innerhalb beider Landschaften niedriger als auf den Referenzflächen. Damit zeigt sich, dass in dieser tropischen Landschaft $\mathrm{CO}_{2^{-}}$und $\mathrm{CH}_{4}$-Flüsse des Bodens durch die Bodenfruchtbarkeit regulieret werden.

Die zweite Studie widmet sich dem Einfluss von Regenwaldumwandlung in kleinbäuerliche Palmöl- und Kautschukplantagen auf $\mathrm{N}_{2} \mathrm{O}$ - und NO-Flüsse des Bodens. Weiterhin wurden $\mathrm{N}_{2} \mathrm{O}$-Flüsse zwischen kleinbäuerlichen und einer großflächig angelegten Palmölplantage verglichen. Innerhalb der beiden Landschaften wurden die $\mathrm{N}_{2} \mathrm{O}$-Flüsse monatlich von Dezember 2012 bis Dezember 2013 und wöchentlich bis zweiwöchentlich zwischen Juli 2014 und Juli 2015 in der großflächig angelegten Palmölplantage bestimmt. Die Messungen wurden mit Hilfe von belüfteten statischen Hauben durchgeführt. NO-Flüsse wurden mittels der offenen, dynamischen Haubenmethode, vier mal in allen Landnutzungen, innerhalb beider Landschaften, zwischen März und September 2013 gemessen. Aufgrund einer geringen Stickstoffverfügbarkeit und damit verbundenen niedrigen $\mathrm{N}_{2} \mathrm{O}$ - und NO-Flüssen auf den Referenzflächen, hatte die Landnutzungsänderung keinen Einfluss auf $\mathrm{N}_{2} \mathrm{O}$ - und NO-Flüsse. Mögliche Fluss-Veränderungen waren aufgrund ihres geringen Ausmaßes nicht bestimmbar. Allerdings emittierte die großflächig angelegte Palmölplantage, wenn auch nicht signifikant, aufgrund höherer Düngereinträge, im Vergleich zu den kleinbäuerlichen Palmölplantagen, durchschnittlich 3,5 mal mehr $\mathrm{N}_{2} \mathrm{O}$.

Das Ziel der dritten Studie war es, $\mathrm{N}_{2} \mathrm{O}$ - und $\mathrm{CH}_{4}$-Flüsse von Ölpalm-Kronendachböden $\mathrm{zu}$ quantifizieren. Flüsse wurden von drei Palmstammbereichen in acht kleinbäuerlichen Palmölplantagen innerhalb der beiden Landschaften gemessen. Die Probenentnahme wurde auf zweiwöchentlicher bis monatlicher Basis zwischen Februar 2013 und Mai 2014 duchgeführt und Spurengasflüsse durch in situ-Inkubierung des Bodens bestimmt. Ölpalm-Kronendachböden emittierten von allen Stammbereichen $\mathrm{N}_{2} \mathrm{O}$ und $\mathrm{CH}_{4}$. Jedoch waren die Flüsse im Vergleich zu jenen des Plantagenbodens gering. Dies lässt sich durch eine geringe Menge Kronendachboden pro Hektar und den hohen Nitratgehalt der Ölpalm-Kronendachböden erklären, welcher die Entstehung von $\mathrm{CH}_{4}$ hemmen kann.

In der Synthese der vorliegenden Arbeit, wurden Daten zu Spurengasflüssen in einen größeren Kontext gesetzt, um Informationen zu Veränderungen des Nettobiomaustausches und 
des partiellen Stickstoffhaushalts durch Landnutzungsänderungen zu erlangen. $\mathrm{CO}_{2}-$ und $\mathrm{CH}_{4}$ Flüsse des Bodens wurden dazu sowohl mit Daten zur Nettoprimärproduktion und Ernte als auch mit Angaben zum Anteil heterotropher Bodenrespiration zur Gesamt-Bodenrespiration kombiniert. $\mathrm{N}_{2} \mathrm{O}$ - und NO-Flüsse des Bodens wurden mit Informationen zu Stickstoffeinträgen sowie -austrägen in Form von Düngung, Niederschlag, Auswaschung und Ernte verbunden. Obwohl der Nettobiomaustausch von Palmölplantagen größer als im Regenwald war, wirkt sich Regenwaldumwandlung in Palmölplantagen negativ auf den Klimawandel aus. Die Umwandlung an sich hat bereits zu so hohen $\mathrm{C}$ Verlusten geführt, dass diese auch über die Zeit nicht durch die Palmölplantagen kompensiert werden können. Das kleinste Stickstoffteilbudget wiesen die Palmölplantagen auf. Dies verdeutlicht, dass Stickstoffinputs in Form von Niederschlag und Düngung die hohen Ernteverluste nicht auszugleichen vermochten. Zusammenfassend veranschaulicht dieser Ansatz, dass Landnutzungsänderungen in tropischen Ökosystemen sowohl den Kohlenstoff- als auch den Stickstoffhaushalt negativ beeinflusst. 


\section{Chapter 1}

\section{General Introduction}

\subsection{Land-use change in Sumatra, Indonesia}

Until the 1950s around $80 \%$ of Sumatra was still covered by forest (Hannibal 1950 as reported by FWI/GFW, 2002). However, with demographic, economic and socio-political pressure this picture soon changed: in the 1970s, intensified clearing of Sumatran rainforest started (Fearnside, 1997; FWI/GFW, 2002) and between 1990 and 2010 alone, Sumatra experienced forest loss of about $36 \%$ (Margono et al., 2012). At the same time, the area under oil palm, timber, rubber and pulp plantations increased (Margono et al., 2012). While forest cover loss in the 1950s-1970s was dominated by the establishment of rubber and agricultural crops (such as rice and coffee), the establishment of pulp, timber and especially oil palm plantations boomed in the 1990s (Margono et al., 2012). Currently, Indonesia is the most important producer of palm oil and the second-largest producer of rubber worldwide (FAO, 2016), with Sumatra contributing around $70 \%$ to Indonesian production (BPS, 2016). For both crops - rubber and oil palm - there is currently high demand. Rubber is mainly used for the production of tires (Clay, 2013), while the rising demand for vegetable oils and biofuels is increasing the popularity of palm oil (McCarthy, 2010).

Tropical forest conversion is known to have negative impacts on the environment; undisturbed tropical forests are important carbon sinks (Pan et al., 2011) and hotspots of biodiversity (e.g., Myers et al., 2000). Forest conversion leads to a decrease in above- and belowground biomass (Adachi et al., 2011; Kotowska et al., 2015; van Straaten et al., 2015), increased carbon dioxide $\left(\mathrm{CO}_{2}\right)$ emissions due to burning or decomposition of cut down biomass (Houghton, 2005; Malhi and Grace, 2000), and a loss of biodiversity (Aratrakorn et al., 2006; Barnes et al., 2014; Wilcove et al., 2013). Land-use change also influences the soil-atmosphere exchange of the trace gases $\mathrm{CO}_{2}$, methane $\left(\mathrm{CH}_{4}\right)$, nitrous oxide $\left(\mathrm{N}_{2} \mathrm{O}\right)$ and nitric oxide (NO) (e.g., Keller et al., 1993; Sheng et al., 2010; Veldkamp et al., 2008). Since all of these gases are climate relevant, it is of importance to quantify changes in trace gas fluxes as a result of forest conversion to rubber and oil palm. 


\subsection{Trace gas fluxes from soil}

Human activities such as fossil fuel combustion, biomass and biofuel burning or agriculture have added large quantities of the greenhouse gases (GHG) $\mathrm{CO}_{2}, \mathrm{CH}_{4}$ and $\mathrm{N}_{2} \mathrm{O}$ as well as of the tropospheric ozone precursor NO to the atmosphere (IPCC, 2013). Soils, on the other hand, are natural controllers of these gases, which are all produced and/or consumed in soil by microbes (see below).

Soils are the largest natural source of $\mathrm{CO}_{2}$ (IPCC, 2013), produced in soil by microbial respiration (heterotrophic) and root respiration (autotrophic) (Luo and Zhou, 2006). Tropical moist forests have the highest soil respiration rates among any other vegetation biome (Raich and Schlesinger, 1992). However, although $\mathrm{CO}_{2}$ is released from soils - forests usually act as $\mathrm{CO}_{2}$ sinks, since plants fix $\mathrm{CO}_{2}$ via photosynthesis (Dalal and Allen, 2008; Pan et al., 2011). Soil $\mathrm{CO}_{2}$ fluxes are primarily driven by soil temperature and moisture, but are also influenced by distal factors such as vegetation type, texture or nutrient status (Luo and Zhou, 2006; Raich and Schlesinger, 1992; Singh and Gupta, 1977).

$\mathrm{CH}_{4}$ is a greenhouse gas with a global warming potential (GWP) 34 times that of $\mathrm{CO}_{2}$ over a 100-year period (IPCC, 2013). Soils can be both, sinks and sources of $\mathrm{CH}_{4}$. While wetlands represent the largest natural $\mathrm{CH}_{4}$ source (IPCC, 2013), well-drained mineral soils generally act as sinks for $\mathrm{CH}_{4}$ (e.g., Luo et al., 2013); thereby tropical forest soils consume considerable amounts of $\mathrm{CH}_{4}$ (Curry, 2007). $\mathrm{CH}_{4}$ is produced during anaerobic decomposition by methanogenic archaea and consumed by methanotrophic bacteria, which are able to utilize $\mathrm{CH}_{4}$ as an energy source via oxidation (Le Mer and Roger, 2001). The main controlling factors of soil $\mathrm{CH}_{4}$ fluxes are soil moisture, gas diffusivity and temperature (Butterbach-Bahl and Papen, 2002; Chen et al., 2010; Verchot et al., 2000), but it has been shown that distal factors such as microbial activity or $\mathrm{N}$ availability also play a role (Veldkamp et al., 2013; Verchot et al., 2000).

$\mathrm{N}_{2} \mathrm{O}$ is a long-lived trace gas with a GWP 298 times higher than that of $\mathrm{CO}_{2}$ over a 100-year period (IPCC, 2013). $\mathrm{N}_{2} \mathrm{O}$ is not only a highly active trace gas but also plays an important role in the depletion of the stratospheric ozone layer (Ravishankara et al., 2009). Globally, soils are the most important source of $\mathrm{N}_{2} \mathrm{O}$ (IPCC, 2013), with tropical soils being a major contributor to the global emissions (Zhuang et al., 2012). NO is a short-lived trace gas 
which is not a greenhouse gas itself but has climate relevance since it plays an important role in the formation of tropospheric ozone (Lammel and Graß1, 1995). Considerable amounts of NO are emitted by soils (Davidson and Kingerlee, 1997), although oxidation of NO into $\mathrm{NO}_{2}$ and subsequent absorption by leaves might limit the amount of NO within the troposphere in biomes with an existing canopy (Jacob and Bakwin, 1991; Sparks et al., 2001). $\mathrm{N}_{2} \mathrm{O}$ and NO are byproducts of nitrification and denitrification, two processes within the nitrogen (N)-cycle of terrestrial ecosystems driven by nitrifying and denitrifying bacteria (Davidson et al., 2000). Nitrogen availability and soil moisture are the most important controllers of N-oxide emissions from soil, whereby the former regulates the total amount of produced $\mathrm{N}_{2} \mathrm{O}$ and $\mathrm{NO}$ and the latter their relative proportion (Davidson et al., 2000; Firestone and Davidson, 1989). Besides these two primary factors, other factors such as soil temperature, soil $\mathrm{pH}$ and the vegetation type have also been identified as influencing factors (Kesik et al., 2006; Kiese and Butterbach-Bahl, 2002; Pilegaard et al., 2006).

\subsection{Land-use change effects on soil trace gas fluxes}

Conversion of tropical rainforest into alternate land uses has been shown to alter the soilatmosphere exchange of $\mathrm{CO}_{2}, \mathrm{CH}_{4}, \mathrm{~N}_{2} \mathrm{O}$ and $\mathrm{NO}$ due to changes in physical, chemical and biological properties of the soils (e.g., Keller and Reiners, 1994; Veldkamp et al., 2008; Werner et al., 2006). Changes in soil $\mathrm{CO}_{2}$ fluxes following forest conversion can often be related to the new established vegetation and its influence on e.g., litter input (Sheng et al., 2010), carbon quality (Werner et al., 2006) or root mass (Melling et al., 2005). Changes in soil $\mathrm{CH}_{4}$ fluxes due to land-use change are mainly related to soil compaction (Keller et al., 1993; Veldkamp et al., 2008) but can also be related to a modified $\mathrm{N}$ status of the soil (Werner et al., 2006). Changes in soil $\mathrm{N}_{2} \mathrm{O}$ and $\mathrm{NO}$ fluxes are primarily controlled by alterations in the soil $\mathrm{N}$ availability and the soil aeration status (Davidson et al., 2000). Increases in soil N-oxide fluxes are especially evident when management practices include the application of $\mathrm{N}$-containing fertilizers (e.g., Palm et al., 2002; Veldkamp et al., 1998).

Land-use change may also affect trace gas fluxes by introducing new accumulations of soil. In oil palm plantations, trees create soil compartments along their stem section; stem and 
leaf bases form unique spaces in which water and considerable amounts of organic material (i.e., decomposed epiphytes and leaf bases) can be trapped. This newly-formed soil, although easily overseen, is a potential source and/ or sink of trace gases. In forest systems, accumulation of epiphytic material, bark and tree litter intercepted by branches leads to the formation of arboreal soils (Enloe et al., 2006) and it has been shown that these soils can release and consume $\mathrm{CO}_{2}$, $\mathrm{CH}_{4}$ and $\mathrm{N}_{2} \mathrm{O}$ (Matson et al., in press). Hitherto research on "oil palm canopy soils", especially on trace gas emissions, has not been conducted.

\subsection{The EEFForTs project}

The EEFForTs project (Ecological and Socioeconomic Functions of Tropical Lowland Rainforest Transformation Systems) is a Collaborative Research Center (CRC 990) funded by the Deutsche Forschungsgemeinschaft (DFG). It is a consortium of the Georg-August University of Göttingen and four Indonesian Universities: the Agricultural University Bogor (IPB), the University of Jambi (UNJA), the University of Tadulako Palu (UNTAD) and the University of Brawijaya Malang (UB), investigating the impact of rainforest transformation into rubber and oil palm plantations on environmental processes, biota, ecosystem services and socioeconomic aspects. The aim is to provide scientific knowledge focused on how to protect and improve the ecosystem functioning of lowland rainforests, rubber and oil palm plantations, thereby enhancing human welfare.

Project sites were located in the lowlands of Jambi Province, Sumatra, Indonesia where conversion of rainforest into rubber and oil palm plantations is common (Fig. 1.1). To investigate land-use change effects on different environmental and socio-cultural aspects, four land uses in two distinct soil landscapes were selected around and within Bukit Duabelas National Park and the Harapan Forest Reserve: forest, rubber trees interspersed in secondary forest (hereafter referred to as jungle rubber), monoculture rubber plantations and monoculture oil palm plantations, each represented by four replicate plots (Fig. 1.1). 


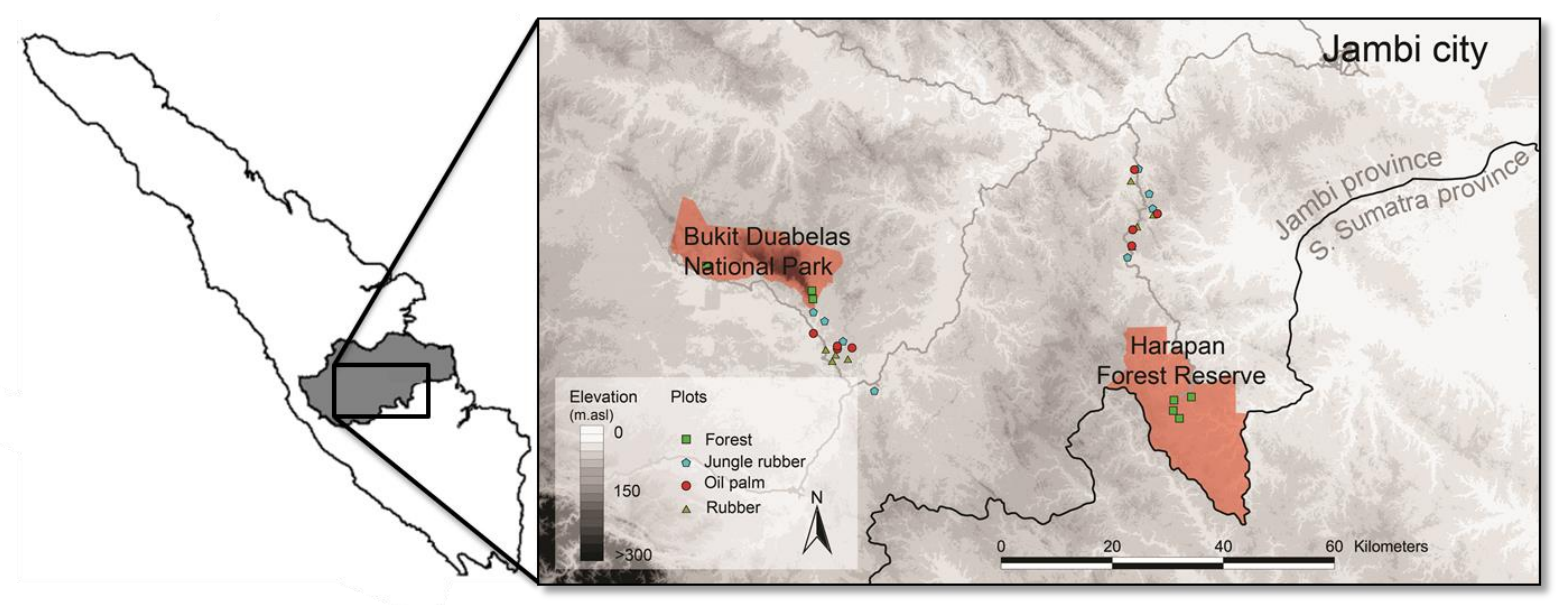

Figure 1.1. Map of Sumatra, Indonesia with the Province of Jambi highlighted (left) and the study area (right) which was delineated into two different landscapes, differing in soil texture: the clay Acrisol landscape within and around the Bukit Duabelas National Park and the loam Acrisol landscape within and around the Harapan Forest Reserve (both protected areas are shaded in orange). Each land use (i.e., forest, jungle rubber, rubber and oil palm) was represented by four replicate plots. Map adapted from (Drescher et al., 2016) (left) and created by Oliver van Straaten (right).

\subsection{Aims and hypotheses}

This thesis consists of three studies which were carried out in Jambi Province, Sumatra, Indonesia within the framework of the EEFForTs project as part of the subproject A05: "Trace gas fluxes and soil $\mathrm{N}$ cycling in heavily weathered soils under rainforest transformation systems". The focus of the first two studies was to assess the effect of rainforest conversion into smallholder rubber and oil palm plantations on soil-atmosphere fluxes of $\mathrm{CO}_{2}$ and $\mathrm{CH}_{4}$ (Study 1), as well as $\mathrm{N}_{2} \mathrm{O}$ and NO (Study 2). The third study focused on determining whether oil palm canopy soils are a source of $\mathrm{N}_{2} \mathrm{O}$ and $\mathrm{CH}_{4}$ (Study 3).

\section{Study 1: Soil fertility controls soil-atmosphere carbon dioxide and methane fluxes in a tropical landscape converted from lowland forest to rubber and oil palm plantations}

The aim of the first study was to quantify changes in soil-atmosphere fluxes of $\mathrm{CO}_{2}$ and $\mathrm{CH}_{4}$ with land-use change and to determine their controlling factors in a lowland landscape in Sumatra, Indonesia. 
Hypotheses:

1. Soil $\mathrm{CO}_{2}$ emissions and $\mathrm{CH}_{4}$ uptake from the reference land uses (forest and jungle rubber) will be higher in the loam than in clay Acrisol landscape.

2. Soil $\mathrm{CO}_{2}$ fluxes and $\mathrm{CH}_{4}$ uptake rates will be higher in the reference land uses (forest and jungle rubber) than in the converted land uses (rubber and oil palm plantations).

\section{Study 2: Soil nitrogen oxide fluxes from lowland forests converted to smallholder rubber and oil palm plantations in Sumatra, Indonesia}

The aim of the second study was to quantify changes in soil-atmosphere fluxes of $\mathrm{N}$-oxides with forest conversion to smallholder oil palm and rubber plantations, to determine the temporal controls of soil $\mathrm{N}$-oxide fluxes measured within one year, and to assess landscape-scale controlling factors of annual soil $\mathrm{N}_{2} \mathrm{O}$ fluxes from converted lowland landscapes in Sumatra, Indonesia

Hypotheses:

1. Soil $\mathrm{N}_{2} \mathrm{O}$ and $\mathrm{NO}$ fluxes from the reference land uses (forest and jungle rubber) will be higher in the clay than the loam Acrisol landscape.

2. The reference land uses (forest and jungle rubber) will have the highest soil $\mathrm{N}_{2} \mathrm{O}$ and $\mathrm{NO}$ fluxes, followed by the fertilized oil palm plantations (fertilized at low to moderate rates), and with lowest fluxes from the unfertilized rubber plantations.

\section{Study 3: Canopy soil of oil palm plantations emits methane and nitrous oxide}

The aim of the third study was to quantify $\mathrm{N}_{2} \mathrm{O}$ and $\mathrm{CH}_{4}$ fluxes from oil palm canopy soil, and to determine the factors that control these greenhouse gas fluxes from oil palm canopy soil in Sumatra, Indonesia.

Hypotheses:

1. Canopy soil from the uppermost stem section (which will be wetter than the lowermost stem section) will have higher $\mathrm{N}_{2} \mathrm{O}$ and $\mathrm{CH}_{4}$ fluxes than the lowermost stem section. 
2. Soil moisture and mineral $\mathrm{N}$ contents will strongly influence these greenhouse gas fluxes from oil palm canopy soil. 


\section{References}

Adachi, M., Ito, A., Ishida, A., Kadir, W. R., Ladpala, P., and Yamagata, Y.: Carbon budget of tropical forests in Southeast Asia and the effects of deforestation: an approach using a processbased model and field measurements, Biogeosciences, 8, 2635-2647, 2011.

Aratrakorn, S., Thunhikorn, S., and Donald, P. F.: Changes in bird communities following conversion of lowland forest to oil palm and rubber plantations in southern Thailand, Bird Conserv. Int., 16, 71-82, 2006.

Barnes, A. D., Jochum, M., Mumme, S., Haneda, N. F., Farajallah, A., Widarto, T. H. and, Brose, U.: Consequences of tropical land use for multitrophic biodiversity and ecosystem functioning, Nat. Commun., 5, 5351, 2014.

BPS (Badan Pusat Statistik): Production of plantation crops by province and crops, Indonesia, 2012-2014, available at: http://www.bps.go.id/linkTableDinamis/view/id/839 (last access: 17 August 2016), 2016.

Butterbach-Bahl, K. and Papen, H.: Four years continuous record of $\mathrm{CH}_{4}$-exchange between the atmosphere and untreated and limed soil of a N-saturated spruce and beech forest ecosystem in Germany, Plant Soil, 240, 77-90, 2002.

Chen, W., Wolf, B., Yao, Z., Brüggemann, N., Butterbach-Bahl, K., Liu, C., Han, S., Han, X., and Zheng, X.: Annual methane uptake by typical semiarid steppe in Inner Mongolia, J. Geophys. Res.-Atmos., 115, D15108, 2010.

Clay, J.: World agriculture and the environment: a commodity-by-commodity guide to impacts and practices, Island Press, Washington, DC, USA, 2013.

Curry, C. L.: Modeling the soil consumption of atmospheric methane at the global scale, Global Biogeochem. Cy., 21, GB4012, 2007.

Dalal, R. C. and Allen, D. E.: Greenhouse gas fluxes from natural ecosystems, Aust. J. Bot., 56, 369-407, 2008.

Davidson, E. A. and Kingerlee, W.: A global inventory of nitric oxide emissions from soils, 
Nutr. Cycl. Agroecosys., 48, 37-50, 1997.

Davidson, E. A., Keller, M., Erickson, H. E., Verchot, L. V., and Veldkamp, E.: Testing a conceptual model of soil emissions of nitrous and nitric oxides, Bioscience, 50, 667-680, 2000.

Drescher, J., Rembold, K., Allen, K., Beckschäfer, P., Buchori, D., Clough, Y., Faust, H., Fauzi, A. M., Gunawan, D., Hertel, D., Irawan, B., et al.: Ecological and socio-economic functions across tropical land use systems after rainforest conversion, Philos. T. Roy. Soc. B., 371, 20150275, 2016.

Enloe, H. A., Graham, R. C., and Sillett, S. C.: Arboreal histosols in old growth redwood forest canopies, Northern California, Soil Sci. Soc. Am. J., 70, 408-418, 2006.

FAO (Food and Agricultural Organization): FAOSTAT database, available at: http://faostat3.fao.org/browse/Q/QC/E (last access 22 March 2016), 2016.

Fearnside, P. M.: Transmigration in Indonesia: lessons from its environmental and social impacts, Environ. Manage., 21, 553-570, 1997.

Firestone, M. K. and Davidson, E. A.: Microbiological basis of $\mathrm{NO}$ and $\mathrm{N}_{2} \mathrm{O}$ production and consumption in soil, in: Exchange of trace gases between terrestrial ecosystems and the atmosphere, edited by: Andreae, M. O. and Schimel, D. S., John Wiley \& Sons Ltd, New York, USA, 7-21, 1989.

FWI/GFW (Forest Watch Indonesia/Global Forest Watch): The state of the forest: Indonesia, FWI/GFW, Bogor, Indonesia, Washington, DC, USA, 2002.

Houghton, R. A.: Tropical deforestation as a source of greenhouse gas emissions, in: Tropical deforestation and climate change, edited by: Mutinho, P. and Schwartzman, S., Instituto de Pesquisa Ambiental da Amazonia, Belém, Brazil, 13-22, 2005.

IPCC: Climate Change 2013: The physical science basis, contribution of working group I to the fifth assessment report of the intergovernmental panel on climate change, Cambridge University Press, Cambridge, UK, New York, USA, 2013.

Jacob, D. and Bakwin, P.: Cycling of NOx in tropical forest canopies, in: Microbial production 
and consumption of greenhouse gases: methane, nitrogen oxides and halomethanes, edited by: Rogers, J. E. and Whitman, W. B., American Society for Microbiology, Washington, DC, USA, 237-253, 1991.

Keller, M. and Reiners, W. A.: Soil-atmosphere exchange of nitrous oxide, nitric oxide, and methane under secondary succession of pasture to forest in the Atlantic lowlands of Costa Rica, Global Biogeochem. Cy., 8, 399-409, 1994.

Keller, M., Veldkamp, E., Weitz, A. M., and Reiners, W. A.: Effect of pasture age on soil tracegas emissions from a deforested area of Costa Rica, Nature, 365, 244-246, 1993.

Kesik, M., Blagodatsky, S., Papen, H., and Butterbach-Bahl, K.: Effect of pH, temperature and substrate on $\mathrm{N}_{2} \mathrm{O}$, NO and $\mathrm{CO}_{2}$ production by Alcaligenes faecalis p., J. Appl. Microbiol., 101, 655-667, 2006.

Kiese, R. and Butterbach-Bahl, K.: $\mathrm{N}_{2} \mathrm{O}$ and $\mathrm{CO}_{2}$ emissions from three different tropical forest sites in the wet tropics of Queensland, Australia, Soil Biol. Biochem., 34, 975-987, 2002.

Kotowska, M. M., Leuschner, C., Triadiati, T., Meriem, S., and Hertel, D.: Quantifying above and belowground biomass carbon loss with forest conversion in tropical lowlands of Sumatra (Indonesia), Glob. Change Biol., 21, 3620-3634, 2015.

Lammel, G. and Graß1, H.: Greenhouse effect of NOx., Environ. Sci. Pollut. R., 2, 40-45, 1995.

Le Mer, J. and Roger, P.: Production, oxidation, emission and consumption of methane by soils: A review, Eur. J. Soil Biol., 37, 25-50, 2001.

Luo, Y. and Zhou, Z.: Soil respiration and the environment, Academic Press, Amsterdam, Netherlands, 2006.

Luo, G. J., Kiese, R., Wolf, B., and Butterbach-Bahl, K.: Effects of soil temperature and moisture on methane uptake and nitrous oxide emissions across three different ecosystem types, Biogeosciences, 10, 3205-3219, 2013.

Malhi, Y. and Grace, J.: Tropical forests and atmospheric carbon dioxide, Trends Ecol. Evol., 15, $332-337,2000$. 
Margono, B. A., Turubanova, S., Zhuravleva, I., Potapov, P., Tyukavina, A., Baccini, A., Goetz, S., and Hansen, M. C.: Mapping and monitoring deforestation and forest degradation in Sumatra (Indonesia) using Landsat time series data sets from 1990 to 2010, Environ. Res. Lett., 7, $034010,2012$.

Matson, A. L., Corre, M. D., and Veldkamp, E.: Canopy soil greenhouse gas dynamics in response to indirect fertilization across an elevation gradient of tropical montane forests, Biotropica, in press.

McCarthy, J.: Processes of inclusion and adverse incorporation: oil palm and agrarian change in Sumatra, Indonesia, J. Peasant Stud., 37, 821-850, 2010.

Melling, L., Hatano, R., and Goh, K. J.: Soil $\mathrm{CO}_{2}$ flux from three ecosystems in tropical peatland of Sarawak, Malaysia, Tellus B, 57, 1-11, 2005.

Myers, N., Mittermeier, R. A., Mittermeier, C. G., da Fonseca, G. B. A., and Kent, J.: Biodiversity hotspots for conservation priorities, Nature, 403, 853-858, 2000.

Palm, C. A., Alegre, J. C., Arevalo, L., Mutuo, P. K., Mosier, A. R., and Coe, R.: Nitrous oxide and methane fluxes in six different land use systems in the Peruvian Amazon, Global Biogeochem. Cy., 16, 21-1-21-13, 2002.

Pan, Y., Birdsey, R. A., Fang, J., Houghton, R., Kauppi, P. E., Kurz, W. A., Phillips, O. L., Shvidenko, A., Lewis, S. L., Canadell, J. G., Ciais, P., et al.: A large and persistent carbon sink in the world's forests, Science, 333, 988-993, 2011.

Pilegaard, K., Skiba, U., Ambus, P., Beier, C., Brüggemann, N., Butterbach-Bahl, K., Dick, J., Dorsey, J., Duyzer, J., Gallagher, M., Gasche, R., et al.: Factors controlling regional differences in forest soil emission of nitrogen oxides ( $\mathrm{NO}$ and $\mathrm{N}_{2} \mathrm{O}$ ), Biogeosciences, 3, 651-661, 2006.

Raich, J. W. and Schlesinger, W. H.: The global carbon dioxide flux in soil respiration and its relationship to vegetation and climate, Tellus B, 44, 81-99, 1992.

Ravishankara, A. R., Daniel, J. S., and Portmann, R. W.: Nitrous oxide $\left(\mathrm{N}_{2} \mathrm{O}\right)$ : the dominant ozone-depleting substance emitted in the 21st century, Science, 326, 123-125, 2009. 
Sheng, H., Yang, Y., Yang, Z., Chen, G., Xie, J., Guo, J., and Zou, S.: The dynamic response of soil respiration to land-use changes in subtropical China, Glob. Change Biol., 16, 1107-1121, 2010.

Singh, J. S. and Gupta, S. R.: Plant decomposition and soil respiration in terrestrial ecosystems, Bot. Rev., 43, 449-528, 1977.

Sparks, J. P., Monson, R. K., Sparks, K. L., and Lerdau, M.: Leaf uptake of nitrogen dioxide $\left(\mathrm{NO}_{2}\right)$ in a tropical wet forest: implications for tropospheric chemistry, Oecologia, 127, 214-221, 2001.

van Straaten, O., Corre, M. D., Wolf, K., Tchienkoua, M., Cuellar, E., Matthews, R. B., and Veldkamp, E.: Conversion of lowland tropical forests to tree cash crop plantations loses up to one-half of stored soil organic carbon, P. Natl. Acad. Sci. USA, 112, 9956-9960, 2015.

Veldkamp, E., Keller, M., and Nuñez, M.: Effects of pasture management on $\mathrm{N}_{2} \mathrm{O}$ and $\mathrm{NO}$ emissions from soils in the humid tropics of Costa Rica, Global Biogeochem. Cy., 12, 71-79, 1998.

Veldkamp, E., Purbopuspito, J., Corre, M. D., Brumme, R., and Murdiyarso, D.: Land use change effects on trace gas fluxes in the forest margins of Central Sulawesi, Indonesia, J. Geophys. Res., 113, G02003, 2008.

Veldkamp, E., Koehler, B., and Corre, M. D.: Indications of nitrogen-limited methane uptake in tropical forest soils, Biogeosciences, 10, 5367-5379, 2013.

Verchot, L. V., Davidson, E. A., Cattânio, J. H., and Ackerman, I. L.: Land-use change and biogeochemical controls of methane fluxes in soils of eastern Amazonia, Ecosystems, 3, 41-56, 2000.

Werner, C., Zheng, X., Tang, J., Xie, B., Liu, C., Kiese, R., and Butterbach-Bahl, K.: $\mathrm{N}_{2} \mathrm{O}, \mathrm{CH}_{4}$ and $\mathrm{CO}_{2}$ emissions from seasonal tropical rainforests and a rubber plantation in Southwest China, Plant Soil, 289, 335-353, 2006.

Wilcove, D. S., Giam, X., Edwards, D. P., Fisher, B., and Koh, L. P.: Navjot's nightmare revisited: logging, agriculture, and biodiversity in Southeast Asia, Trends Ecol. Evol., 28, 531- 
540, 2013.

Zhuang, Q., Lu, Y., and Chen, M.: An inventory of global $\mathrm{N}_{2} \mathrm{O}$ emissions from the soils of natural terrestrial ecosystems, Atmos. Environ., 47, 66-75, 2012. 


\title{
Chapter 2
}

\section{Soil fertility controls soil-atmosphere carbon dioxide and methane fluxes in a tropical landscape converted from lowland forest to rubber and oil palm plantations}

\author{
Evelyn Hassler, Marife D. Corre, Aiyen Tjoa, Muhammad Damris, Sri Rahayu Utami, \\ Edzo Veldkamp
}

Published in Biogeosciences; doi: 10.5194/bg-12-5831-2015

\begin{abstract}
Expansion of palm oil and rubber production, for which global demand is increasing, causes rapid deforestation in Sumatra, Indonesia, and is expected to continue in the next decades. Our study aimed to (1) quantify changes in soil $\mathrm{CO}_{2}$ and $\mathrm{CH}_{4}$ fluxes with land-use change and (2) determine their controlling factors. In Jambi Province, Sumatra, we selected two landscapes on heavily weathered soils that differ mainly in texture: loam and clay Acrisol soils. In each landscape, we investigated the reference land-use types (forest and secondary forest with regenerating rubber) and the converted land-use types (rubber, 7-17 years old, and oil palm plantations, 9-16 years old). We measured soil $\mathrm{CO}_{2}$ and $\mathrm{CH}_{4}$ fluxes monthly from December 2012 to December 2013. Annual soil $\mathrm{CO}_{2}$ fluxes from the reference land-use types were correlated with soil fertility: low extractable phosphorus $(\mathrm{P})$ coincided with high annual $\mathrm{CO}_{2}$ fluxes from the loam Acrisol soil that had lower fertility than the clay Acrisol soil $(P<0.05)$. Soil $\mathrm{CO}_{2}$ fluxes from the oil palm (107.2 to $115.7 \mathrm{mg} \mathrm{C} \mathrm{m}^{-2} \mathrm{~h}^{-1}$ ) decreased compared to the other land-use types (between 178.7 and $195.9 \mathrm{mg} \mathrm{C} \mathrm{m}^{-2} \mathrm{~h}^{-1} ; P<0.01$ ). Across land-use types, annual $\mathrm{CO}_{2}$ fluxes were positively correlated with soil organic carbon (C) and negatively correlated with ${ }^{15} \mathrm{~N}$ signatures, extractable $\mathrm{P}$ and base saturation. This suggests that the reduced soil $\mathrm{CO}_{2}$ fluxes from oil palm were the result of strongly decomposed soil organic matter and reduced soil $\mathrm{C}$ stocks due to reduced litter input as well as being due to a possible reduction in $\mathrm{C}$ allocation to roots due to improved soil fertility from liming and $\mathrm{P}$ fertilization in these plantations. Soil $\mathrm{CH}_{4}$ uptake in the reference land-use types was negatively correlated with net nitrogen $(\mathrm{N})$ mineralization and soil mineral $\mathrm{N}$, suggesting $\mathrm{N}$ limitation of $\mathrm{CH}_{4}$ uptake, and positively correlated with exchangeable aluminum ( $\mathrm{Al}$ ), indicating a decrease in methanotrophic activity at
\end{abstract}


high $\mathrm{Al}$ saturation. Reduction in soil $\mathrm{CH}_{4}$ uptake in the converted land-use types (ranging from -3.0 to $-14.9 \mu \mathrm{g} \mathrm{C} \mathrm{m}^{-2} \mathrm{~h}^{-1}$ ) compared to the reference land-use types (ranging from -20.8 to $-40.3 \mu \mathrm{g} \mathrm{C} \mathrm{m}^{-2} \mathrm{~h}^{-1} ; P<0.01$ ) was due to a decrease in soil $\mathrm{N}$ availability in the converted landuse types. Our study shows for the first time that differences in soil fertility control the soilatmosphere exchange of $\mathrm{CO}_{2}$ and $\mathrm{CH}_{4}$ in a tropical landscape, a mechanism that we were able to detect by conducting this study on the landscape scale.

\subsection{Introduction}

Oil palm (Elaeis guineensis) and rubber (Hevea brasiliensis) are two of the fastest-expanding tree cash crops in the tropics (Clay, 2013). Global oil palm production has quintupled from 1990 to 2013 and is currently grown on an estimated area of 17 million hectare (Mha) (Food and Agricultural Organization, 2014). Indonesia contributes nearly half of the global palm oil production (Food and Agricultural Organization, 2014) and is planning to double its production in the coming decade (Carlson et al., 2013). Similarly, rubber is grown on around 10 Mha globally, and Indonesia is the second largest rubber producer (Food and Agricultural Organization, 2014). Most Indonesian oil palm and rubber production is located in Sumatra (Indonesian Ministry of Agriculture, 2014), where the conversion of lowland rainforest to plantations has been widespread (Laumonier et al., 2010). It has been estimated that plantation establishment has caused a loss of 7.5 Mha of Sumatran natural forest in the last 2 decades (1990-2010) (Margono et al., 2012), and future expansion will probably be at the expense of large areas of tropical forest, unless a properly planned and spatially explicit development strategy is implemented (Koh and Ghazoul, 2010).

Although the majority of remaining lowland tropical forests are located on nutrient-poor, heavily weathered soils, these ecosystems are among the most productive worldwide and contain globally significant above- and belowground carbon stocks. The high ecosystem

productivity is possible despite the nutrient-poor soils because of efficient cycling of rock-derived nutrients (phosphorus $(\mathrm{P})$ and base cations) between vegetation and soil and also high soil nitrogen $(\mathrm{N})$ availability caused by biological $\mathrm{N}$ fixation (Hedin et al., 2009). Conversion of tropical forest to agricultural land-use systems does not only decrease biodiversity and contribute to climate change (Danielsen et al., 2009) but also alters soil fertility 
and soil physical properties in the newly established land-use systems (Dechert et al., 2004; Klinge et al., 2004). Burning of slashed vegetation is typically part of forest conversion, releasing large amounts of nutrients previously bound in the vegetation. A considerable part of these nutrients ends up in the soil but is susceptible to losses (through leaching and gaseous emission), which are especially high in the earlier years of crop establishment and decrease with time (Klinge et al., 2004). Furthermore, forest conversion is often associated with increases in soil bulk density. These dynamic changes in soil fertility and soil bulk density following forest conversion do not only affect agricultural production but also the soil-atmosphere exchange of trace gases like carbon dioxide $\left(\mathrm{CO}_{2}\right)$ and methane $\left(\mathrm{CH}_{4}\right)$ since their production, consumption and exchange are directly related to soil fertility and soil bulk density (Keller et al., 1993; Veldkamp et al., 2008).

Globally, soils are the largest natural source of $\mathrm{CO}_{2}$ (IPCC, 2007), which is released during respiration processes of microbial communities and roots (Raich and Schlesinger, 1992). While the important proximal controllers of soil $\mathrm{CO}_{2}$ fluxes are soil temperature and moisture, it has been demonstrated that other distal regulators such as vegetation type and soil physical and biochemical properties (e.g., bulk density, texture, $\mathrm{pH}$, carbon stocks) also affect soil $\mathrm{CO}_{2}$ fluxes (Raich and Schlesinger, 1992). Soils also play a dominant role in the production and consumption of $\mathrm{CH}_{4}$, a greenhouse gas with a global warming potential 23 times that of $\mathrm{CO}_{2}$ over a 100-year time period (IPCC, 2007). In soils, $\mathrm{CH}_{4}$ can be produced during anaerobic decomposition by methanogenic archaea, while $\mathrm{CH}_{4}$ can also be consumed by methanotrophic bacteria which are able to utilize $\mathrm{CH}_{4}$ as an energy source. Whether net consumption or net emission of $\mathrm{CH}_{4}$ occurs at the soil surface depends on the balance between production and consumption in the soil. For soil $\mathrm{CH}_{4}$ fluxes, the proximal controllers are soil moisture, gas diffusivity and temperature, while other distal regulators include microbial activity, $\mathrm{N}$ availability and aluminum toxicity (Bodelier and Laanbroek, 2004; Tamai et al., 2003; Veldkamp et al., 2013; Verchot et al., 2000).

In tropical lowland forest landscapes with heavily weathered soils, much of the spatial variability in trace gas fluxes appears to be related to soil texture (Sotta et al., 2006). In the Brazilian Amazon, lowland forests on Acrisol and Ferralsol soils display high soil $\mathrm{CO}_{2}$ emissions with large variations among sites that relate to soil texture: soils with sandy loam 
to sandy clay loam texture had 21-36\% higher $\mathrm{CO}_{2}$ emissions than soils with clay texture (Keller et al., 2005; Sotta et al., 2006). Moreover, although well-drained soils in tropical lowland forests generally act as a sink for $\mathrm{CH}_{4}$ (Keller and Reiners, 1994; Veldkamp et al., 2013; Verchot et al., 2000), their differences in $\mathrm{CH}_{4}$ uptake are explicable by their differences in soil texture. In a review of 16 tropical lowland forests, the only factor correlating annual $\mathrm{CH}_{4}$ fluxes with site characteristics was a significant positive correlation with clay contents, indicating that the higher the clay content the lower the $\mathrm{CH}_{4}$ uptake (Veldkamp et al., 2013).

Since much of the original forest in our study area have been converted to oil palm and rubber plantations, the management practices in these land-use types added important factors that influence soil $\mathrm{CO}_{2}$ and $\mathrm{CH}_{4}$ fluxes from these converted landscapes. Earlier studies have shown that forest conversion to agricultural land-use types in the tropics lead to considerable changes in soil $\mathrm{CO}_{2}$ fluxes, which were related to changes in belowground $\mathrm{C}$ allocation (Davidson et al., 2000; Salimon et al., 2004), carbon quality (Werner et al., 2006), living fine-root biomass and litter input (Ishizuka et al., 2002; Sheng et al., 2010). Conversion of tropical forest to agricultural land use causes a reduction in soil $\mathrm{CH}_{4}$ uptake or even turns the soil into a source of $\mathrm{CH}_{4}$. Often this trend is explained by soil compaction, which leads to reduced gas diffusivity and accordingly limits aerobic $\mathrm{CH}_{4}$ oxidation while enhancing anaerobic $\mathrm{CH}_{4}$ production (Keller et al., 1993; Veldkamp et al., 2008). Changes in $\mathrm{N}$ availability may also play a role since $\mathrm{CH}_{4}$ uptake may be N limited (Bodelier and Laanbroek, 2004; Veldkamp et al., 2013) and high concentrations of ammonium $\left(\mathrm{NH}_{4}^{+}\right.$, e.g., from fertilization) can inhibit $\mathrm{CH}_{4}$ oxidation (Veldkamp et al., 2001; Werner et al., 2006). Finally, termites are known to produce $\mathrm{CH}_{4}$, and their presence may also affect the balance between production and consumption of $\mathrm{CH}_{4}($ Seiler et al., 1984).

Although Sumatra, Indonesia, represents a hot spot of land-use change, especially for the establishment of rubber and oil palm plantations, how this affects soil $\mathrm{CO}_{2}$ and $\mathrm{CH}_{4}$ fluxes remains highly uncertain for the following reasons: (1) most studies relating land-use change to trace gas emissions have been conducted in South and Central America (Davidson et al., 2000; Keller and Reiners, 1994; Salimon et al., 2004; Veldkamp et al., 2001; Verchot et al., 2000) and only few studies were conducted in southeast Asia (Ishizuka et al., 2002; Veldkamp et al., 2008); (2) most studies have focused on forest conversion to traditional land-use types, such as maize, 
pastures, slash-and-burn agriculture, cacao and coffee, and less on the rapidly expanding tree cash crops such as rubber and oil palm; (3) the few studies that reported $\mathrm{CO}_{2}$ and $\mathrm{CH}_{4}$ fluxes from oil palm plantations were conducted on peat soils (Melling et al., 2005a, b), whereas the studies conducted on mineral soils, where most of the rubber and oil palm plantations are located, were either conducted without spatial replication, covered only short periods of measurements (Adachi et al., 2005; Ishizuka et al., 2002; Werner et al., 2006) or measured only once (Ishizuka et al., 2005). It is imperative that better information becomes available on trace gas fluxes from these economically important and rapidly expanding rubber and oil palm plantations. Whether palmoil-based biofuel does indeed have environmental advantages compared to fossil fuel depends, among many factors, on the greenhouse gas balance during oil palm fruit production.

In the present study, our aims were to (1) quantify changes in soil-atmosphere fluxes of $\mathrm{CO}_{2}$ and $\mathrm{CH}_{4}$ with land-use change and (2) determine their controlling factors in a converted lowland landscape in Sumatra, Indonesia. Soil-atmosphere fluxes of $\mathrm{CO}_{2}$ and $\mathrm{CH}_{4}$ were measured in forest and secondary forest with regenerating rubber (hereafter called jungle rubber, which is a more traditional rubber agroforestry system; Gouyon et al., 1993) as reference landuse types and the converted land-use types of monoculture rubber and oil palm plantations. Our study was designed to cover these four land-use types in each of the two landscapes on highly weathered soils that differed mainly in texture: clay and loam Acrisol soils. We tested the following hypotheses: (1) soil $\mathrm{CO}_{2}$ emissions and $\mathrm{CH}_{4}$ uptake will be higher in loam than in clay Acrisol soils, and (2) soil $\mathrm{CO}_{2}$ fluxes and $\mathrm{CH}_{4}$ uptake rates will be higher in the reference landuse types (forest and jungle rubber) than in the converted land-use types (rubber and oil palm plantations). Here, we present the first spatially replicated study with a full year of measurements that investigates soil $\mathrm{CO}_{2}$ and $\mathrm{CH}_{4}$ fluxes from conversion of forest or jungle rubber to rubber and oil palm plantations on mineral soils. We also evaluate the effect of management intensity since we compare rubber plantations without fertilizer inputs with fertilized oil palm plantations. Our results will be a critical contribution to trace gas lifecycle assessment of rubber and palm oil at the production stage. 


\subsection{Material and methods}

\section{Study area and experimental design}

The study area is located in the lowlands (35-95 m above sea level) of Jambi Province, Sumatra, Indonesia. In the past 2 decades, forest cover in Jambi Province decreased by 1.14 Mha, which was about $40 \%$ of the forest cover in 1990 (Margono et al., 2012). The climate is humid tropical with a mean annual air temperature of $26.7 \pm 0.1{ }^{\circ} \mathrm{C}$ and a mean annual precipitation of $2235 \pm$ $385 \mathrm{~mm}$ (1991-2011; data relating to Jambi Sultan Thaha Airport from the Indonesian Meteorological, Climatological and Geophysical Agency). The dry season is usually from May to September and the rainy season occurs from October to April. In 2013, during our study period, the wet season lasted slightly longer, while a drier period was detected between mid-June and the end of October. During this dry period, rainfall was reduced by $35-57 \%$ compared to the wetter months during which rainfall was 333-362 mm per month.

We selected two landscapes on heavily weathered soils that differed mainly in texture: loam Acrisol soil ( $36 \pm 6 \%$ sand, $32 \pm 4 \%$ silt and $32 \pm 2 \%$ clay in the top $0.5 \mathrm{~m}$ ) and clay Acrisol soil ( $26 \pm 6 \%$ sand, $29 \pm 3 \%$ silt and $45 \pm 4 \%$ clay in the top $0.5 \mathrm{~m}$ ). This textural difference led to differences in soil fertility: forest sites in the clay Acrisol soil had a higher base saturation, Bray-extractable P and lower Al saturation compared to those in the loam Acrisol soil $(P \leq 0.01$ to 0.04; Appendix Table A2.1; Allen et al., 2015). Detailed soil physical and biochemical characteristics from our study sites were measured by Allen et al. (2015) and are summarized in Table A2.1. Acrisol soils cover about $50 \%$ of the land area in Sumatra and about one third of Indonesia (FAO et al., 2009). The clay Acrisol landscape was located about $160 \mathrm{~km}$ southwest of Jambi City between $01.94^{\circ} \mathrm{S}, 102.58^{\circ} \mathrm{E}$ and $02.14^{\circ} \mathrm{S}, 102.85^{\circ} \mathrm{E}$. Forest sites in this landscape were established within the Bukit Duabelas National Park (administered by the Ministry of Forestry, PHKA). The loam Acrisol landscape was located about $80 \mathrm{~km}$ southwest of Jambi City between $01.79^{\circ} \mathrm{S}, 103.24^{\circ} \mathrm{E}$ and $2.19^{\circ} \mathrm{S}, 103.36^{\circ} \mathrm{E}$. The forest sites in this landscape were established within the Harapan Forest Reserve and had been partially logged in the past (administered by the Restoration Ecosystem Indonesia Harapan, PT REKI).

In each landscape, we studied four land-use types: lowland forest, jungle rubber, and smallholder monoculture plantations of rubber and oil palm. In Jambi Province, the smallholder rubber and oil palm plantations were established after clearing and burning either the forest 
(often partially logged) or jungle rubber (based on interviews conducted by Euler et al.; unpublished data). Thus, in our study the lowland forest and jungle rubber served as the reference land-use types, representing the baseline conditions with which we compared the rubber and oil palm plantations.

For each of the four land-use types within each landscape, we selected four replicate plots $(50 \mathrm{~m} \times 50 \mathrm{~m}$ each with a minimum distance of $200 \mathrm{~m}$ between plots), totalling 32 plots that were all located on relatively flat, well-drained positions in the landscape. Additional information on tree species composition, tree density, tree height, basal area, and plantation age of these plots is reported in Table A2.2. Within each plot, we established a $10 \times 10$ grid which was used to select four randomly nested subplots $(5 \mathrm{~m} \times 5 \mathrm{~m}$ each) that were at least $5 \mathrm{~m}$ from the plot's border. In each subplot, we placed one permanent chamber base at random to measure soil trace gas fluxes.

This approach of comparing soil $\mathrm{CO}_{2}$ and $\mathrm{CH}_{4}$ fluxes from the converted land-use types to that from the reference land-use types in order to assess the effects of land-cover change has the implicit assumption that before land-use conversion, soil characteristics were comparable. We tested this assumption by comparing the land-use-independent soil characteristics, i.e., clay content in 0.50-2.00 m depth, among land-use types within each landscape. Since there were no significant differences in clay contents between the reference and converted land-use types at these depths (Table A2.1; Allen et al., 2015), we deduced that the sites within each landscape had previously similar soil characteristics and that differences in trace gas fluxes can be attributed to the changes in land-use type and its associated management practices.

Since all the plantations were managed by smallholders, management practices of rubber and oil palm were diverse. The following information on management practices was based on our interviews of the smallholders. In 2013, oil palm and rubber plantations were weeded once or twice a year either manually or using herbicide (most commonly 2-5 L Gramaxone ${ }^{\circledR}$ or Roundup ${ }^{\circledR} \mathrm{ha}^{-1} \mathrm{yr}^{-1}$ ). Oil palm plantations were fertilized, whereas rubber plantations were not. Oil palm plantations in the clay Acrisol landscape were fertilized only once during the rainy season, whereas those in the loam Acrisol landscape had a second fertilizer application in the dry season. The most commonly used fertilizers were NPK complete fertilizer (i.e., Phonska, Mahkota), potassium chloride $(\mathrm{KCl})$ and urea. Plantations fertilized once received about $300 \mathrm{~kg}$ 
NPK fertilizer $\mathrm{ha}^{-1} \mathrm{yr}^{-1}$ and plantations fertilized twice received about $550 \mathrm{~kg}$ NPK fertilizer $\mathrm{ha}^{-1} \mathrm{yr}^{-1}$. In terms of nutrient elements added, these rates were equivalent to $48-88 \mathrm{~kg} \mathrm{~N} \mathrm{ha}^{-1} \mathrm{yr}^{-1}$, 21-38 $\mathrm{kg} \mathrm{Pha}^{-1} \mathrm{yr}^{-1}$ and 40-73 $\mathrm{kg} \mathrm{K} \mathrm{ha}^{-1} \mathrm{yr}^{-1}$. Additionally, three of the smallholders applied 157 and $143 \mathrm{~kg} \mathrm{KCl}-\mathrm{K} \mathrm{ha}^{-1} \mathrm{yr}^{-1}$ and two of the smallholders applied $138 \mathrm{~kg}^{-}$urea-N ha ${ }^{-1} \mathrm{yr}^{-1}$. One of the smallholders also applied lime in 2013 at about $200 \mathrm{~kg}$ dolomite $\mathrm{ha}^{-1} \mathrm{yr}^{-1}$. Smallholders typically applied the fertilizer around the oil palm tree at about $0.8-1 \mathrm{~m}$ distance from the tree base. Additionally, senescing fronds were regularly cut and piled on the interrows of an oil palm plantation, typically in the middle of the $9 \mathrm{~m}$ distance between rows of oil palms. Oil palm fruits were harvested every 2 weeks, whereas the latex of the rubber and jungle rubber was collected weekly.

In addition to the monthly flux measurements conducted at the smallholder farms described above, we simulated fertilizations and conducted more frequent measurements (6 to 11 times) during 3 to 8 weeks following fertilization as the monthly sampling may have missed the short-term effect of fertilization on soil $\mathrm{CO}_{2}$ and $\mathrm{CH}_{4}$ fluxes. We chose three plots of oil palm plantations in each of the two landscapes, and in each plot we selected three trees separated by an interrow distance of $9 \mathrm{~m}$ (in total, 18 oil palm trees). At $0.8 \mathrm{~m}$ distance from the base of each tree, we applied the fertilizer manually to the area within $0.2 \mathrm{~m}$ around the tree using the same rate that smallholders applied to these oil palm plantations (i.e., equivalent to $2 \mathrm{~kg}$ fertilizer per tree, based on $300 \mathrm{~kg}$ NPK fertilizer ha ${ }^{-1}$ divided by 134-140 trees ha ${ }^{-1}$; Table A2.2). We used the same fertilizer forms that smallholders applied, i.e., NPK complete fertilizer in the clay Acrisol landscape and a combination of $\mathrm{KCl}$, ammonium sulfate and NPK complete fertilizer in the loam Acrisol landscape. One chamber base was placed at $0.3 \mathrm{~m}$ distance from the tree base (chamber location a); another chamber base, to which fertilizer was applied, was placed at $0.8 \mathrm{~m}$ distance from the tree (chamber location $\mathrm{b}$ ); and a third chamber was placed at 4-4.5 m distance from the tree and served as a reference chamber without direct fertilizer application (chamber location c). In the clay Acrisol landscape, measurements in the three oil palm plots were done from mid-October to mid-December 2013, mid-February to mid-March 2014, and mid-February to mid-April 2013. In the loam Acrisol landscape, measurements were done from the end of October 2013 to mid-December 2013, mid-January to mid-March 2014, and mid-March to the start of April 2014. Shorter intervals of sampling days (Appendix Fig. A2.1) were conducted right after the fertilizer application. 


\section{$\mathrm{CO}_{2}$ and $\mathrm{CH}_{4}$ flux measurement}

Soil $\mathrm{CO}_{2}$ and $\mathrm{CH}_{4}$ fluxes were measured monthly from December 2012 to December 2013, using static vented chambers. We are aware that the use of static vented chambers for $\mathrm{CO}_{2}$ and $\mathrm{CH}_{4}$ flux measurements could have possible sources of error due to changes in diffusion gradients during chamber closure. We have however adapted the design of our chambers and the flux calculation to minimize, if not avoid, these possible errors (see below). A clear advantage of the static vented chamber method compared to other methods is that it remains the only operational method that can be used to measure trace gas fluxes at a large number of plots (in our case 32) spread over a large area with regular measurements within a year. Furthermore, it also yields information on short-distance spatial variability of trace gas fluxes, which cannot be quantified by more integrative tower-based methods. Our chamber bases were made of polyvinyl chloride $\left(0.05 \mathrm{~m}^{2}\right.$ area) and inserted $\sim 0.03 \mathrm{~m}$ into the soil. We placed a permanent chamber base at random in each of the four subplots per replicate plot 1 month before the first measurement started. Since the area occupied by piled fronds or applied with fertilizer in oil palm plantations was relatively small, none of these randomly placed chamber bases (range of distance to the tree base was 1.8-5 m) happened to be located in such an area. During sampling, the chamber bases were covered with polyethylene hoods $(0.27 \mathrm{~m}$ total chamber height and $12 \mathrm{~L}$ total volume $)$ equipped with a Luer-lock sampling port and a vent for pressure equilibrium. Four gas samples (30 mL each) were removed at 1,11, 21 and $31 \mathrm{~min}$ after chamber closure using a plastic syringe connected to the Luer-lock port. Immediately after sampling, gas samples were stored with overpressure in pre-evacuated $12 \mathrm{~mL}$ Labco Exetainers ${ }^{\circledR}$ (Labco Limited, Lampeter, UK) with rubber septa that were only used once. Our group has tested these exetainers for an extended period of sample storage (e.g., up to 6 months) and air transport by storing and transporting standard gases of known concentrations in overpressure, and these exetainers were proven to be leak proof. Gas samples in exetainers were transported to Germany by air every 3-4 months and were analyzed upon arrival using a gas chromatograph (GC 6000 Vega Series 2, Carlo Erba Instruments, Milan, Italy, with an ASPEC autosampler, Gilson SAS, Villiers, Le Bel, France), equipped with a flame ionization detector and an electron capture detector. Three standard gases were used for calibration with concentrations from 350 to $5000 \mathrm{ppm}$ for $\mathrm{CO}_{2}$ and 1000 to 5000 ppb for $\mathrm{CH}_{4}$ (Deuste Steininger $\mathrm{GmbH}$, Mühlhausen, Germany). The software Probe66 version 1.3 (Messwert $\mathrm{GmbH}$, Göttingen, Germany) was used to determine $\mathrm{CH}_{4}$ and $\mathrm{CO}_{2}$ sample 
concentrations by comparing integrated peak areas with those of the standard gases. Fluxes were calculated from the concentration change over the duration of chamber closure and adjusted with actual air temperature and pressure measured at the time of sampling. The linearity of increase in $\mathrm{CO}_{2}$ concentrations with the duration of chamber closure $\left(R^{2} \geq 0.98\right)$ was checked for each chamber measurement, and in a few cases where concentration curved at the last sampling time, we excluded the last data point and calculated the fluxes based on the linear increase in concentrations during the first three samplings. The majority of the measurements showed a linear change in $\mathrm{CH}_{4}$ concentrations with the duration of chamber closure. There were a few measurements when changes in $\mathrm{CH}_{4}$ concentrations with time of chamber closure were small, mostly when net $\mathrm{CH}_{4}$ uptake was low; in such cases, the calculated $\mathrm{CH}_{4}$ flux using linear regression was not significantly different from zero. These fluxes were, however, retained in the statistical analyses to avoid bias by excluding low $\mathrm{CH}_{4}$ fluxes or by assuming that these fluxes were zero. Assuming constant flux rates per day, annual soil $\mathrm{CO}_{2}$ and $\mathrm{CH}_{4}$ fluxes from the monthly sampling and total fluxes during a fertilization event were calculated by adopting the trapezoidal rule on time intervals between measured flux rates, similar to the method we employed in our earlier studies (e.g., Koehler et al., 2009; Veldkamp et al., 2013).

\section{Auxiliary measurements}

Soil temperature, moisture and mineral $\mathrm{N}$ content were measured with each trace gas measurement. Soil temperature was determined in the top $0.05 \mathrm{~m}$ depth using a GMH 1170 digital thermometer (Greisinger electronic $\mathrm{GmbH}$, Regenstauf, Germany). Soil samples for mineral $\mathrm{N}$ content were also taken from the top $0.05 \mathrm{~m}$ at approximately $1 \mathrm{~m}$ distance from each chamber with four soil samples per plot. These four soil samples were pooled to represent each replicate plot on each day of measurement, and roots, leaves and twigs were manually removed. For the fertilization experiment, soil samples taken near each chamber location ( $a, b$ and $c)$ were processed separately. Since even short storage of disturbed soil samples can affect mineral $\mathrm{N}$ concentrations (Arnold et al., 2008), extraction was done in the field immediately following soil sampling. A soil sample was added to a prepared $250 \mathrm{~mL}$ plastic bottle containing $150 \mathrm{~mL}$ of

$0.5 \mathrm{~mol} \mathrm{~L}^{-1} \mathrm{~K}_{2} \mathrm{SO}_{4}$ (approximately $1: 3$ ratio of fresh soil to extractant volume) and transported to the field station. At the field station, samples were shaken for $1 \mathrm{~h}$, filtered through prewashed 
(with $0.5 \mathrm{~mol} \mathrm{~L}^{-1} \mathrm{~K}_{2} \mathrm{SO}_{4}$ ) filter papers (Whatman, GE Healthcare Life Sciences, $4 \mu \mathrm{m}$ nominal pore size), and the filtrate was immediately stored in a freezer. The remaining field-moist soil samples were stored in plastic bags and gravimetric moisture content was determined at the field station, for which 50-100 g of fresh soil was dried at $105^{\circ} \mathrm{C}$ for at least 1 day. The gravimetric moisture content was used to calculate the dry mass of the soil extracted for mineral N. Frozen extracts were transported by air to Germany to ensure that they stayed frozen throughout the transport until analysis. At our laboratory at the University of Göttingen, Germany, $\mathrm{NH}_{4}{ }^{+}$and $\mathrm{NO}_{3}{ }^{-}$concentrations in the extracts were analyzed using continuous flow injection colorimetry (SEAL Analytical AA3, SEAL Analytical GmbH, Norderstedt, Germany). $\mathrm{NH}_{4}{ }^{+}$was determined by salicylate and dicloroisocyanuric acid reaction (Autoanalyzer Method G-102-93), and $\mathrm{NO}_{3}{ }^{-}$ was determined by the cadmium reduction method with an $\mathrm{NH}_{4} \mathrm{Cl}$ buffer (Autoanalyzer Method G-254-02). Soil water content was expressed as water-filled pore space (WFPS), calculated using

a particle density of $2.65 \mathrm{~g} \mathrm{~cm}^{-3}$ for mineral soil and the measured bulk densities at our study sites (Table A2.1).

\section{Statistical analysis}

All statistical analyses of the monthly measurements of soil $\mathrm{CO}_{2}$ and $\mathrm{CH}_{4}$ fluxes were conducted using the means of the four chambers (or subplots) that represent each replicate plot on a given sampling day. Data were checked for normal distribution (using Shapiro-Wilk tests), and if necessary, a logarithmic (for $\mathrm{CO}_{2}, \mathrm{CH}_{4}$, and mineral $\mathrm{N}$ ) or square root (for WFPS) transformation was used. For our first objective, we conducted comparisons of the reference land-use types between the two landscapes in order to test the first hypothesis. Then we carried out comparisons among land-use types within each landscape to test our second hypotheses. Linear mixed-effect models (LMEs) were applied (Crawley, 2007) with either landscape (i.e., comparing landscapes for each reference land use) or land use (i.e., comparing land-use types within each landscape) as the fixed effect and replicate plots and sampling days as the random effects. For the fertilization experiment, we tested differences in soil $\mathrm{CO}_{2}$ and $\mathrm{CH}_{4}$ fluxes between chamber locations within each oil palm plantation plot, using LMEs with chamber location as the fixed effect and palm trees and sampling days as the random effects. We extended the LME model to include either (1) a variance function that allows different variances of the 
fixed effect and/or (2) a first-order temporal autoregressive process, which assumes that correlation between measurements decreases with increasing time difference if this improved the relative goodness of the model fit based on the Akaike information criterion. Fixed effect was considered significant based on the analysis of variance at $P \leq 0.05$, and differences between landscapes or land-use types (or chamber locations for the fertilization experiment) were assessed using Fisher's least significant difference (LSD) test $(P \leq 0.05)$. For our second objective, we assess how soil factors influence the seasonal variations in soil $\mathrm{CO}_{2}$ and $\mathrm{CH}_{4}$ fluxes, using Pearson's correlation tests with soil temperature, WFPS, $\mathrm{NO}_{3}{ }^{-}, \mathrm{NH}_{4}{ }^{+}$and total mineral N. This assessment of seasonal controls of trace gas fluxes was conducted for each land-use type within each landscape using the means of the four replicate plots (as spatial representation) on each of the 12 monthly measurements in order to focus the analysis on temporal variation. Lastly, we assessed the influence of soil physical and biochemical characteristics (Table A2.1) on the spatial variations in soil annual $\mathrm{CO}_{2}$ and $\mathrm{CH}_{4}$ fluxes first on the reference land-use types across landscapes (16 plots) and second across land-use types within each landscape (16 plots), using Spearman's rank correlation test. The first was to assess the spatial controls of trace gas fluxes from the reference land-use types, and the second was to evaluate which soil factors drive the spatial variation in trace gas fluxes across land-use types. We used the annual fluxes as temporal representation in order to focus this analysis on the spatial variation. For all correlation tests, statistical significance was taken at $P \leq 0.05$, except in a few cases for which a marginal significance at $P \leq 0.09$ was considered because our experimental design encompassed the inherent spatial variability in the studied landscapes. All statistical analyses were conducted using R 3.0.2 (R Development Core Team, 2013).

\subsection{Results}

\section{Reference land-use types (forest and jungle rubber): comparison between landscapes}

WFPS in the jungle rubber was higher in the clay than loam Acrisol soils $(P<0.01)$, but, in the

forest, WFPS did not differ between landscapes $(P=0.56$; Fig. 2.1a, b). In both landscapes, we detected lower WFPS during the drier period (mean WFPS ranged from 38 to $80 \%$ between mid-June and October) compared to the wetter period (mean WFPS ranged from 50 to $96 \%$; 
$P<0.01$; Fig. 2.1a, b). Soil temperatures in the forest were lower in the clay than loam Acrisol soils $(P=0.02$; Fig. $2.1 \mathrm{c}, \mathrm{d})$, which was probably due to the difference in the time of the day when measurements were conducted. Soil temperatures in the jungle rubber did not differ between landscapes $(P=0.17)$.
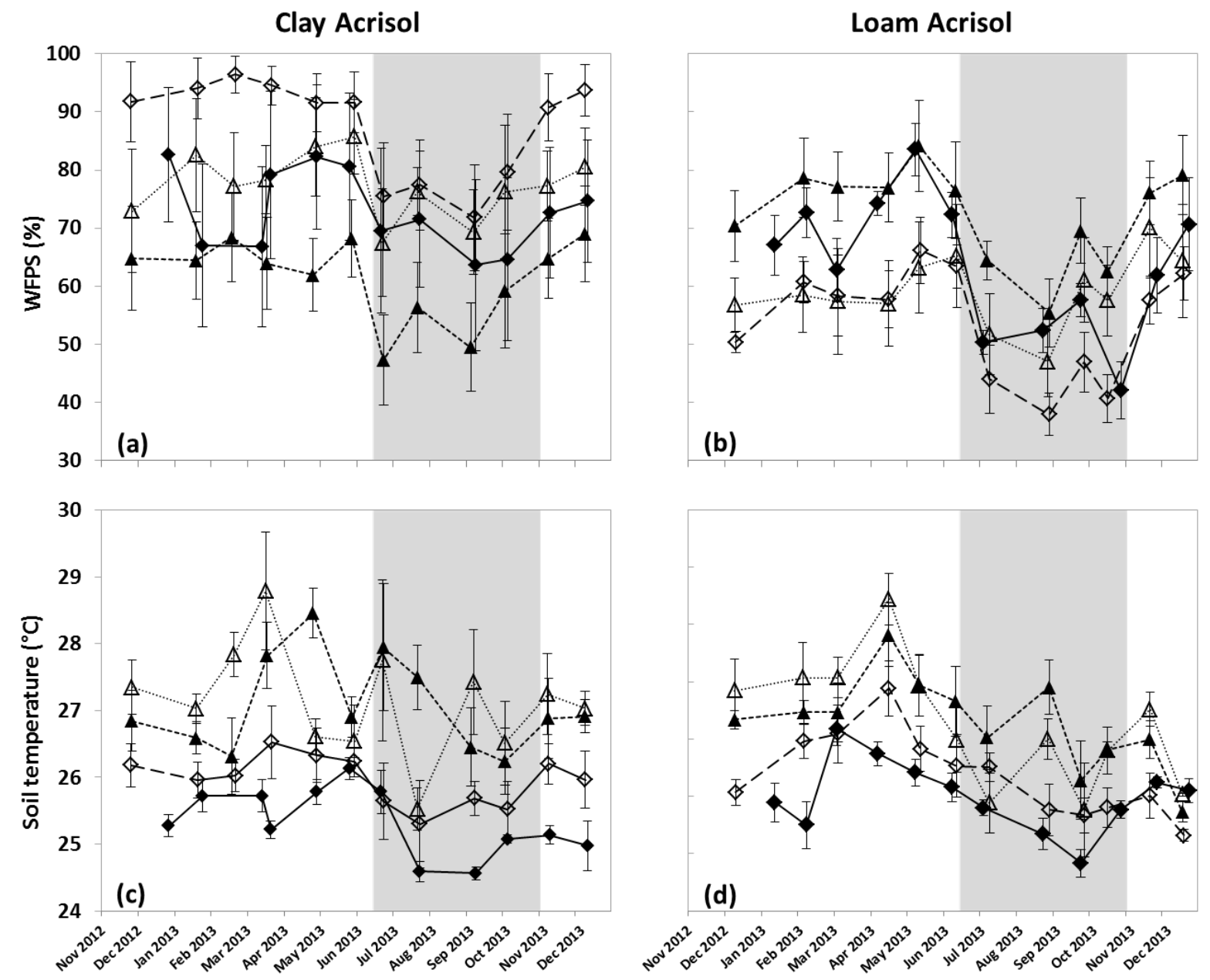

Figure 2.1. Mean $( \pm$ SE, $n=4)$ soil water-filled pore space (WFPS) and soil temperature in the top $0.05 \mathrm{~m}$ depth under forest $(\bullet)$, jungle rubber $(\diamond)$, rubber $(\boldsymbol{\Delta})$ and oil palm $(\Delta)$ in the clay Acrisol soil (a and $\mathbf{c})$ and the loam Acrisol soil (b and d) in Jambi, Sumatra, Indonesia, measured monthly from December 2012 to December 2013. Grey shadings mark the dry season.

In both landscapes, $\mathrm{NH}_{4}{ }^{+}$was the dominant form of mineral $\mathrm{N}$ (Table 2.1). Soil $\mathrm{NH}_{4}{ }^{+}$contents in the jungle rubber were higher in the clay than in loam Acrisol soils $(P=0.02)$, but in the forest 
soil $\mathrm{NH}_{4}{ }^{+}$contents did not differ between landscapes $\left(P=0.90\right.$; Table 2.1). Soil $\mathrm{NO}_{3}{ }^{-}$contents in the forest were higher in the clay than in loam Acrisol soils $(P<0.01)$, whereas soil $\mathrm{NO}_{3}{ }^{-}$ contents in the jungle rubber were higher in the loam than in clay Acrisol soils $(P=0.02$; Table 2.1). Total mineral $\mathrm{N}$ contents in both reference land-use types did not differ between landscapes $(P=0.11-0.19 ;$ Table 2.1).

Table 2.1. Mean $( \pm \mathrm{SE}, n=4)$ soil-extractable mineral nitrogen in the top $0.05 \mathrm{~m}$ depth for different land-use types within each soil landscape in Jambi, Sumatra, Indonesia, measured monthly from December 2012 to December 2013. Means followed by different lowercase letters indicate significant differences among land-use types within a soil landscape and different capital letters indicate significant differences between soil landscapes within a land-use type (linear mixed-effect models with Fisher's least significant difference (LSD) test at $P \leq 0.05$ ).

\begin{tabular}{llll}
\hline $\begin{array}{l}\text { Land-use type } \\
\text { clay Acrisol soil }\end{array}$ & $\begin{array}{l}\mathrm{NH}_{4}{ }^{+} \\
\left(\mathrm{mg} \mathrm{N} \mathrm{kg}^{-1}\right)\end{array}$ & $\begin{array}{l}\mathrm{NO}_{3}{ }^{-} \\
\left(\mathrm{mg} \mathrm{N} \mathrm{kg}^{-1}\right)\end{array}$ & $\begin{array}{l}\text { mineral N } \\
\left(\mathrm{mg} \mathrm{N} \mathrm{kg}^{-1}\right)\end{array}$ \\
\hline Forest & $6.99 \pm 1.03^{\mathrm{a}, \mathrm{A}}$ & $2.15 \pm 0.36^{\mathrm{a}, \mathrm{A}}$ & $9.14 \pm 1.34^{\mathrm{a}, \mathrm{A}}$ \\
Jungle rubber & $7.33 \pm 0.21^{\mathrm{a}, \mathrm{A}}$ & $0.23 \pm 0.06^{\mathrm{b}, \mathrm{B}}$ & $7.56 \pm 0.26^{\mathrm{b}, \mathrm{A}}$ \\
Rubber & $4.25 \pm 0.23^{\mathrm{b}, \mathrm{A}}$ & $0.05 \pm 0.01^{\mathrm{b}, \mathrm{B}}$ & $4.30 \pm 0.23^{\mathrm{c}, \mathrm{A}}$ \\
Oil palm & $5.80 \pm 0.64^{\mathrm{a}, \mathrm{A}}$ & $0.81 \pm 0.49^{\mathrm{b}, \mathrm{A}}$ & $6.60 \pm 0.42^{\mathrm{b}, \mathrm{A}}$ \\
\hline loam Acrisol soil & & & \\
\hline Forest & $5.94 \pm 0.40^{\mathrm{a}, \mathrm{A}}$ & $0.61 \pm 0.15^{\mathrm{ab}, \mathrm{B}}$ & $6.55 \pm 0.28^{\mathrm{a}, \mathrm{A}}$ \\
Jungle rubber & $5.64 \pm 0.28^{\mathrm{a}, \mathrm{B}}$ & $1.25 \pm 0.63^{\mathrm{a}, \mathrm{A}}$ & $6.89 \pm 0.59^{\mathrm{a}, \mathrm{A}}$ \\
Rubber & $4.14 \pm 0.57^{\mathrm{b}, \mathrm{A}}$ & $0.12 \pm 0.02^{\mathrm{b}, \mathrm{A}}$ & $4.26 \pm 0.58^{\mathrm{b}, \mathrm{A}}$ \\
Oil palm & $4.20 \pm 1.10^{\mathrm{b}, \mathrm{B}}$ & $0.60 \pm 0.36^{\mathrm{ab}, \mathrm{B}}$ & $4.81 \pm 1.44^{\mathrm{b}, \mathrm{B}}$ \\
\hline
\end{tabular}

We detected no differences in soil $\mathrm{CO}_{2}$ fluxes between landscapes for the reference land-use types $\left(P=0.63-0.69\right.$; Table 2.2; Fig. 2.2a, b). Similarly, soil $\mathrm{CH}_{4}$ fluxes from both reference land-use types were also comparable between the two landscapes $(P=0.26-0.27$; Table 2.2; Fig. 2.2c, d). However, in the loam Acrisol soil, two of the four forest sites displayed net $\mathrm{CH}_{4}$ emissions in $26 \%$ of the measurements, which resulted in its largest variation among plots (as indicated by its largest standard error around the mean; Table 2.2). 

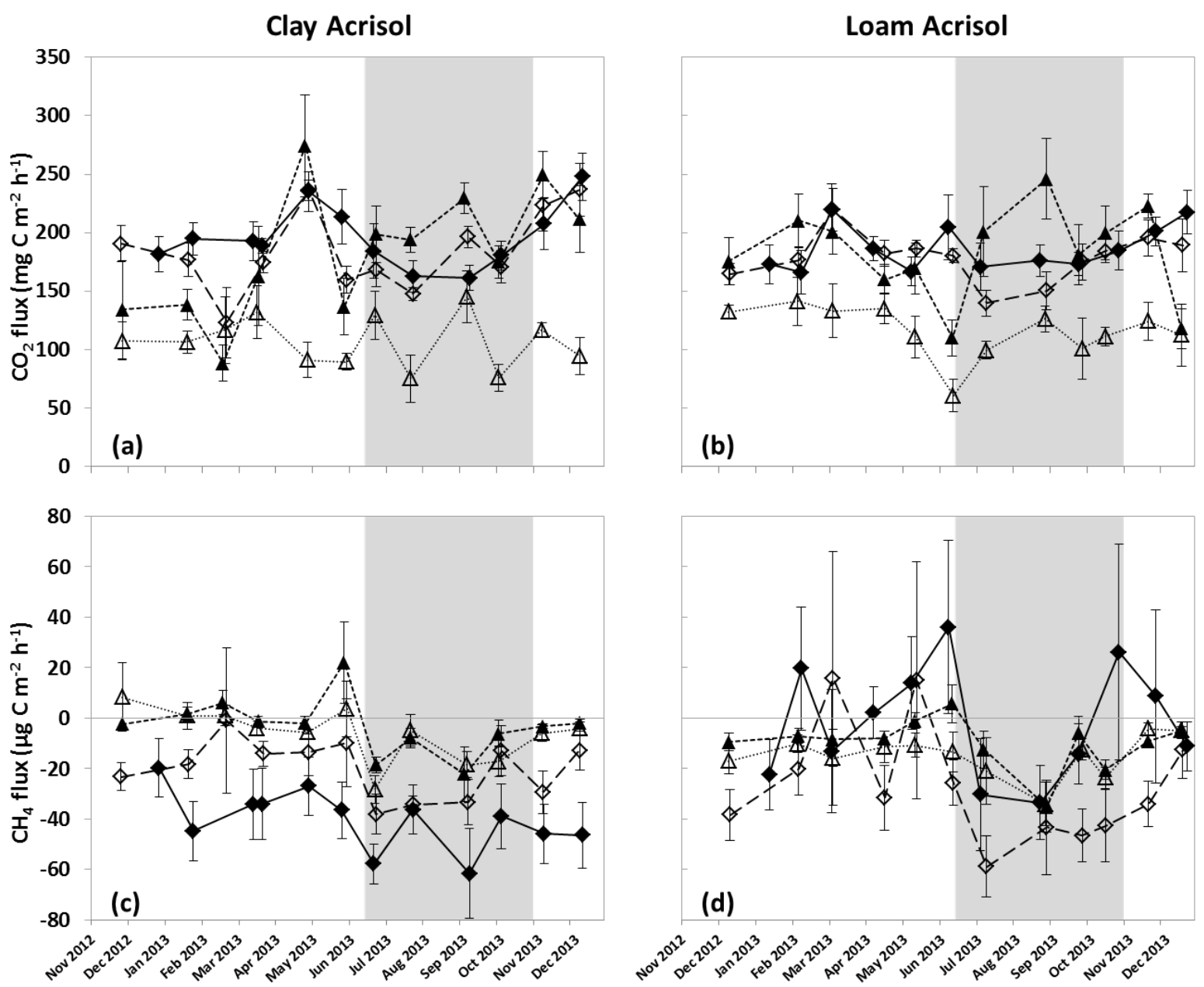

Figure 2.2. Mean $( \pm \mathrm{SE}, n=4)$ soil $\mathrm{CO}_{2}$ fluxes and soil $\mathrm{CH}_{4}$ fluxes from forest $(\diamond)$, jungle rubber $(\diamond)$,

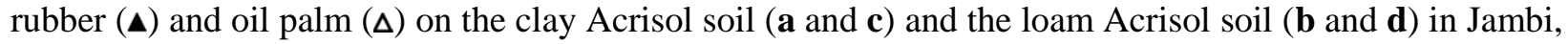
Sumatra, Indonesia, measured monthly from December 2012 to December 2013. Grey shadings mark the dry season. 
Table 2.2. Mean $( \pm \mathrm{SE}, n=4)$ soil $\mathrm{CO}_{2}$ and $\mathrm{CH}_{4}$ fluxes and annual soil $\mathrm{CO}_{2}$ and $\mathrm{CH}_{4}$ fluxes from different land-use types within each soil landscape in Jambi, Sumatra, Indonesia, measured monthly from December 2012 to December 2013. Means followed by different lowercase letters indicate significant differences among land-use types within a soil landscape and different capital letters indicate significant differences between soil landscapes within a land-use type (linear mixed-effect models with Fisher's LSD test at $P \leq 0.05$ ). Annual soil $\mathrm{CO}_{2}$ and $\mathrm{CH}_{4}$ fluxes were not statistically tested for differences between landscapes or land-use types since these annual values are trapezoidal extrapolations. For the loam Acrisol soil, $\mathrm{CH}_{4}$ fluxes in parenthesis included only the two forest sites that had a dominantly net $\mathrm{CH}_{4}$ uptake, and comparison among land-use types was conducted between jungle rubber, rubber and oil palm, which all showed net $\mathrm{CH}_{4}$ uptake.

\begin{tabular}{|c|c|c|c|c|}
\hline Land-use type & $\begin{array}{l}\mathrm{CO}_{2} \text { fluxes } \\
\left(\mathrm{mg} \mathrm{C} \mathrm{m}^{-2} \mathrm{~h}^{-1}\right)\end{array}$ & $\begin{array}{l}\text { Annual } \mathrm{CO}_{2} \text { fluxes } \\
\left(\mathrm{Mg} \mathrm{C} \mathrm{ha}^{-1} \text { year }^{-1}\right)\end{array}$ & $\begin{array}{l}\mathrm{CH}_{4} \text { fluxes } \\
\left(\mu \mathrm{g} \mathrm{m}^{-2} \mathrm{~h}^{-1}\right)\end{array}$ & $\begin{array}{l}\text { Annual } \mathrm{CH}_{4} \text { fluxes } \\
\left(\mathrm{kg} \mathrm{C} \mathrm{ha}^{-1} \text { year }^{-1}\right)\end{array}$ \\
\hline \multicolumn{5}{|c|}{ clay Acrisol soil } \\
\hline Forest & $195.93 \pm 13.51^{\mathrm{a}, \mathrm{A}}$ & $16.93 \pm 1.19$ & $-40.30 \pm 10.25^{\mathrm{c}, \mathrm{A}}$ & $-3.63 \pm 0.89$ \\
\hline Jungle rubber & $185.25 \pm 9.40^{\mathrm{a}, \mathrm{A}}$ & $16.11 \pm 0.72$ & $-20.79 \pm 7.24^{\mathrm{b}, \mathrm{A}}$ & $-1.85 \pm 0.59$ \\
\hline Rubber & $182.77 \pm 16.22^{\mathrm{a}, \mathrm{A}}$ & $16.09 \pm 1.40$ & $-3.00 \pm 1.26^{\mathrm{a}, \mathrm{A}}$ & $-0.29 \pm 0.12$ \\
\hline Oil palm & $107.24 \pm 7.23^{\mathrm{b}, \mathrm{A}}$ & $9.22 \pm 0.61$ & $-6.37 \pm 3.06^{\mathrm{a}, \mathrm{A}}$ & $-0.52 \pm 0.26$ \\
\hline \multicolumn{5}{|c|}{ loam Acrisol soil } \\
\hline Forest & $186.64 \pm 13.72^{\mathrm{a}, \mathrm{A}}$ & $16.21 \pm 1.17$ & $\begin{array}{l}-1.56 \pm 17.07^{\mathrm{A}} \\
(-29.45 \pm 11.92)\end{array}$ & $-0.18 \pm 1.55$ \\
\hline Jungle rubber & $178.69 \pm 11.17^{\mathrm{a}, \mathrm{A}}$ & $15.55 \pm 0.94$ & $-26.92 \pm 3.85^{\mathrm{b}, \mathrm{A}}$ & $-2.42 \pm 0.34$ \\
\hline Rubber & $182.86 \pm 14.47^{\mathrm{a}, \mathrm{A}}$ & $16.52 \pm 1.32$ & $-9.73 \pm 3.79^{\mathrm{a}, \mathrm{A}}$ & $-0.93 \pm 0.35$ \\
\hline Oil palm & $115.74 \pm 10.99^{\mathrm{b}, \mathrm{A}}$ & $10.29 \pm 0.88$ & $-14.94 \pm 3.14^{\mathrm{a}, \mathrm{A}}$ & $-1.38 \pm 0.31$ \\
\hline
\end{tabular}

Converted land-use types (rubber and oil palm plantations): comparisons to the reference land-use types within each landscape

While in both landscapes WFPS did not differ among land-use types $(P=0.12-0.26$; Fig. 2.1a, b), soil temperatures were slightly higher in the plantations $\left(27.2 \pm 0.1{ }^{\circ} \mathrm{C}\right)$ compared to the reference land-use types $\left(25.9 \pm 0.1^{\circ} \mathrm{C}\right)$ in each landscape (both $P<0.01$; Fig. $2.1 \mathrm{c}, \mathrm{d}$ ). Soil $\mathrm{NH}_{4}{ }^{+}$contents in rubber were lower than in all other land-use types in the clay Acrisol soil $(P=0.05)$, and soil $\mathrm{NH}_{4}{ }^{+}$contents in both rubber and oil palm were also lower than in the reference land-use types in the loam Acrisol soil $(P=0.03$; Table 2.1). In the clay Acrisol soil, $\mathrm{NO}_{3}{ }^{-}$contents in rubber and oil palm were lower than in forest $(P<0.01)$, and in the loam Acrisol soil $\mathrm{NO}_{3}{ }^{-}$contents in rubber were lowest, whereas these were intermediary in oil palm $(P<0.01$; Table 2.1). The latter was related to fertilizer application by the owner of one of the oil palm plots just a month prior to our measurement. Total mineral $\mathrm{N}$ showed similar differences 
among land-use types in each landscape to those for soil $\mathrm{NH}_{4}{ }^{+}$and $\mathrm{NO}_{3}{ }^{-}$contents (both $P<0.01$; Table 2.1).

Soil $\mathrm{CO}_{2}$ fluxes from oil palm were $45 \%$ lower in the clay Acrisol soil and $38 \%$ lower in the loam Acrisol soil compared to the forest (both $P<0.01$; Table 2.2; Fig. 2.2a, b). From the fertilization experiment, soil $\mathrm{CO}_{2}$ fluxes within $1 \mathrm{~m}$ of the oil palm base (chamber locations a and $b$ ) were on average $2.3 \pm 0.2$ times higher than those $4-4.5 \mathrm{~m}$ from the tree base (chamber location c) in both landscapes (all $P<0.01$; Table A2.3). However, this area within $1 \mathrm{~m}$ distance to the tree base is only $3 \mathrm{~m}^{2}$ per tree or $4 \%$ on a hectare basis. Even if we were to include these elevated soil $\mathrm{CO}_{2}$ fluxes into annual estimates using area-weighted contributions, the high fluxes within $1 \mathrm{~m}$ distance to the tree base would account for less than the standard errors (7-9\%) of the mean annual fluxes.

Soil $\mathrm{CH}_{4}$ uptake in the plantations was $84 \%$ (oil palm) and $93 \%$ (rubber) lower compared to the forest and $69 \%$ (oil palm) and $86 \%$ (rubber) lower compared to the jungle rubber in the clay Acrisol soil $(P<0.01$; Table 2.2; Fig. 2.2c, d). Also in the loam Acrisol soil, $\mathrm{CH}_{4}$ uptake in the plantations was lower (reduction of $64 \%$ for rubber and $44 \%$ for oil palm) compared to jungle rubber $\left(P=0.02\right.$; Table 2.2; Fig. 2.2c, d). However, $\mathrm{CH}_{4}$ uptake in the forest on loam Acrisol soils deviated from the differences detected in the clay Acrisol soils because of the two forest sites that displayed net $\mathrm{CH}_{4}$ emissions (see above; Table 2.2; Fig. 2.2d). From the fertilization experiment, soil $\mathrm{CH}_{4}$ uptake from the area of fertilizer application (chamber location b) was $2.6 \pm 0.2$ times lower than the unfertilized chamber locations a and c (respectively $0.3 \mathrm{~m}$ and 4-4.5 $\mathrm{m}$ from the oil palm base) $(P \leq 0.01-0.05$; Table A2.3), with the exception of plot 3 in the clay Acrisol soil ( $P=0.45$; Table A2.3). In most cases, $\mathrm{CH}_{4}$ uptake in chamber location b was reduced immediately following fertilizer application and was restored to prefertilization values after about 6 weeks (Fig. A2.1). Even if we included these reduced soil $\mathrm{CH}_{4}$ fluxes into annual estimates using area-weighted contributions, the low area coverage $(\sim 1.3 \%$ of 1 ha) and time duration (12\% of 1 year) would render a negligible effect. 


\section{Seasonal controls of $\mathrm{CO}_{2}$ and $\mathrm{CH}_{4}$ fluxes from each land-use type}

In the clay Acrisol soil, $\mathrm{CH}_{4}$ fluxes were positively correlated with WFPS (Table 2.3) in each of the four land-use types, signifying the higher $\mathrm{CH}_{4}$ uptake in the dry than in the wet season ( $P \leq 0.01-0.03$; Fig. 2.2c). Soil $\mathrm{CH}_{4}$ fluxes correlated negatively with $\mathrm{NO}_{3}{ }^{-}$contents in forest and with soil $\mathrm{CO}_{2}$ fluxes in rubber (Table 2.3). Across all land-use types, soil $\mathrm{CH}_{4}$ uptake was negatively correlated with total mineral $\mathrm{N}$ content $(R=-0.47, P \leq 0.01, n=41$; Fig. $2.3 \mathrm{a})$ and $\mathrm{NO}_{3}{ }^{-}$content $(R=-0.73, P \leq 0.01, n=41)$. Some correlations in Table 2.3 were possibly spurious: in oil palm, soil $\mathrm{CO}_{2}$ fluxes were positively correlated with soil temperatures (Table 2.3) even if the temperate range was small $\left(25.5-28.8^{\circ} \mathrm{C}\right)$ such that this correlation was likely caused by the differences in sampling time during the day rather than by a seasonal temperature pattern. In jungle rubber, plotting soil $\mathrm{CO}_{2}$ fluxes against soil $\mathrm{NO}_{3}{ }^{-}$contents showed that their correlation (Table 2.3) was apparently caused by a group of many low $\mathrm{NO}_{3}{ }^{-}$contents against one high $\mathrm{NO}_{3}{ }^{-}$value and this correlation became insignificant when the one high value was removed. Also, in rubber, the marginal negative correlation between soil $\mathrm{CH}_{4}$ fluxes with $\mathrm{NO}_{3}{ }^{-}$contents was due to the correlation between WFPS and $\mathrm{NO}_{3}{ }^{-}$contents.

In the loam Acrisol soil, seasonal variations in soil $\mathrm{CO}_{2}$ fluxes were positively correlated with WFPS in jungle rubber and negatively correlated with WFPS in rubber (Table 2.3). Some correlations in Table 2.3 were also spurious, caused by differences in sampling time during the day rather than by a seasonal pattern: correlation between soil $\mathrm{CO}_{2}$ fluxes and soil temperature in forest and oil palm despite narrow temperate ranges $\left(24.8-27.2^{\circ} \mathrm{C}\right.$ in forest and $25.8-29.4{ }^{\circ} \mathrm{C}$ in oil palm). The negative correlation between soil $\mathrm{CO}_{2}$ fluxes and $\mathrm{NO}_{3}{ }^{-}$contents in jungle rubber was driven by the negative correlation between WFPS and $\mathrm{NO}_{3}{ }^{-}$(Table 2.3). As was observed in the clay Acrisol soil, seasonal variation in soil $\mathrm{CH}_{4}$ fluxes from the loam Acrisol soil was positively correlated with WFPS in each of the three land-use types (Table 2.3) with the exception of the forest which was caused by one extreme $\mathrm{CH}_{4}$ emission from a single chamber (656.47 $\mu \mathrm{g} \mathrm{C} \mathrm{m}^{-2} \mathrm{~h}^{-1}$ ). When this one value was excluded, a positive correlation between soil $\mathrm{CH}_{4}$ fluxes and WFPS was also detected for forest $(R=0.60, P \leq 0.01, n=12)$. Soil $\mathrm{CH}_{4}$ fluxes also correlated positively with soil $\mathrm{CO}_{2}$ fluxes in jungle rubber, whereas this correlation was negative in rubber (Table 2.3). In the jungle rubber, soil $\mathrm{CH}_{4}$ fluxes correlated negatively with soil $\mathrm{NO}_{3}{ }^{-}$contents (Table 2.3). Across land-use types, we also observed negative correlations of 
Table 2.3. Pearson correlation coefficients $(n=12)$ between soil $\mathrm{CO}_{2}$ flux $\left(\mathrm{mg} \mathrm{C} \mathrm{m}^{-2} \mathrm{~h}^{-1}\right)$, soil $\mathrm{CH}_{4}$ flux $\left(\mu \mathrm{g} \mathrm{C} \mathrm{m}^{-2} \mathrm{~h}^{-1}\right)$, soil temperature $\left({ }^{\circ} \mathrm{C}\right.$, top $0.05 \mathrm{~m}$ depth), water-filled pore space (WFPS) $(\%$, top $0.05 \mathrm{~m}$ depth) and extractable mineral nitrogen ( $\mathrm{mg} \mathrm{N} \mathrm{kg}^{-1}$, top $0.05 \mathrm{~m}$ depth), using the monthly-measurement means of the four replicate plots per land-use type between December 2012 and December 2013.

\begin{tabular}{|c|c|c|c|c|c|c|c|}
\hline Land-use type & Variable & Soil $\mathrm{CH}_{4}$ flux & Soil temp. & WFPS & $\mathrm{NH}_{4}{ }^{+}$ & $\mathrm{NO}_{3}^{-}$ & mineral $\mathrm{N}$ \\
\hline \multicolumn{8}{|c|}{ clay Acrisol soil } \\
\hline \multirow[t]{4}{*}{ Forest } & Soil $\mathrm{CO}_{2}$ flux & 0.19 & 0.42 & 0.49 & -0.17 & 0.37 & -0.01 \\
\hline & Soil $\mathrm{CH}_{4}$ flux & & 0.25 & $0.68^{\mathrm{b}}$ & 0.18 & $-0.59^{b}$ & -0.09 \\
\hline & Soil temperature & & & 0.34 & $0.63^{\mathrm{b}}$ & -0.32 & $0.54^{\mathrm{a}}$ \\
\hline & WFPS & & & & 0.25 & -0.18 & 0.18 \\
\hline \multirow[t]{4}{*}{ Jungle rubber } & Soil $\mathrm{CO}_{2}$ flux & -0.03 & 0.38 & 0.21 & -0.39 & $0.61^{b}$ & 0.27 \\
\hline & Soil $\mathrm{CH}_{4}$ flux & & 0.49 & $0.74^{\mathrm{c}}$ & 0.33 & -0.19 & 0.34 \\
\hline & Soil temperature & & & $0.78^{c}$ & 0.34 & 0.19 & 0.39 \\
\hline & WFPS & & & & 0.25 & 0.07 & 0.28 \\
\hline \multirow[t]{4}{*}{ Rubber } & Soil $\mathrm{CO}_{2}$ flux & $-0.51^{\mathrm{a}}$ & 0.49 & -0.39 & 0.05 & 0.14 & 0.06 \\
\hline & Soil $\mathrm{CH}_{4}$ flux & & -0.14 & $0.84^{\mathrm{c}}$ & -0.06 & $-0.52^{\mathrm{a}}$ & -0.10 \\
\hline & Soil temperature & & & -0.24 & 0.30 & 0.16 & 0.31 \\
\hline & WFPS & & & & -0.06 & $-0.53^{\mathrm{a}}$ & -0.10 \\
\hline \multirow[t]{4}{*}{ Oil palm } & Soil $\mathrm{CO}_{2}$ flux & -0.29 & $0.82^{c}$ & -0.37 & 0.31 & 0.24 & 0.41 \\
\hline & Soil $\mathrm{CH}_{4}$ flux & & -0.09 & $0.69^{c}$ & 0.19 & 0.13 & 0.25 \\
\hline & Soil temperature & & & -0.19 & 0.32 & 0.32 & $0.52^{\mathrm{a}}$ \\
\hline & WFPS & & & & 0.16 & 0.08 & 0.16 \\
\hline \multicolumn{8}{|c|}{ loam Acrisol soil } \\
\hline \multirow[t]{4}{*}{ Forest } & Soil $\mathrm{CO}_{2}$ flux & 0.12 & $0.58^{b}$ & 0.05 & -0.12 & 0.23 & -0.01 \\
\hline & Soil $\mathrm{CH}_{4}$ flux & & 0.19 & 0.32 & 0.09 & -0.24 & -0.24 \\
\hline & Soil temperature & & & 0.42 & 0.41 & -0.03 & 0.37 \\
\hline & WFPS & & & & 0.40 & -0.33 & 0.23 \\
\hline \multirow[t]{4}{*}{ Jungle rubber } & Soil $\mathrm{CO}_{2}$ flux & $0.74^{\mathrm{c}}$ & 0.21 & $0.59^{b}$ & -0.05 & $-0.60^{b}$ & -0.41 \\
\hline & Soil $\mathrm{CH}_{4}$ flux & & 0.35 & $0.74^{\mathrm{c}}$ & 0.35 & $-0.58^{b}$ & 0.11 \\
\hline & Soil temperature & & & 0.42 & 0.47 & -0.22 & 0.38 \\
\hline & WFPS & & & & 0.32 & $-0.67^{b}$ & 0.05 \\
\hline \multirow[t]{4}{*}{ Rubber } & Soil $\mathrm{CO}_{2}$ flux & $-0.74^{\mathrm{c}}$ & 0.16 & $-0.54^{\mathrm{a}}$ & 0.06 & -0.07 & 0.05 \\
\hline & Soil $\mathrm{CH}_{4}$ flux & & -0.07 & $0.84^{\mathrm{c}}$ & 0.33 & -0.11 & 0.32 \\
\hline & Soil temperature & & & 0.07 & $0.57^{\mathrm{b}}$ & -0.42 & $0.54^{\mathrm{a}}$ \\
\hline & WFPS & & & & 0.23 & -0.24 & 0.20 \\
\hline \multirow[t]{4}{*}{ Oil palm } & Soil $\mathrm{CO}_{2}$ flux & -0.05 & $0.57^{\mathrm{a}}$ & -0.29 & 0.25 & 0.36 & -0.05 \\
\hline & Soil $\mathrm{CH}_{4}$ flux & & 0.16 & $0.86^{\mathrm{c}}$ & 0.06 & 0.17 & 0.10 \\
\hline & Soil temperature & & & 0.08 & 0.13 & -0.19 & 0.16 \\
\hline & WFPS & & & & -0.08 & -0.05 & -0.07 \\
\hline
\end{tabular}

${ }^{\mathrm{a}} P \leq 0.09,{ }^{\mathrm{b}} P \leq 0.05,{ }^{\mathrm{c}} P \leq 0.01$ 

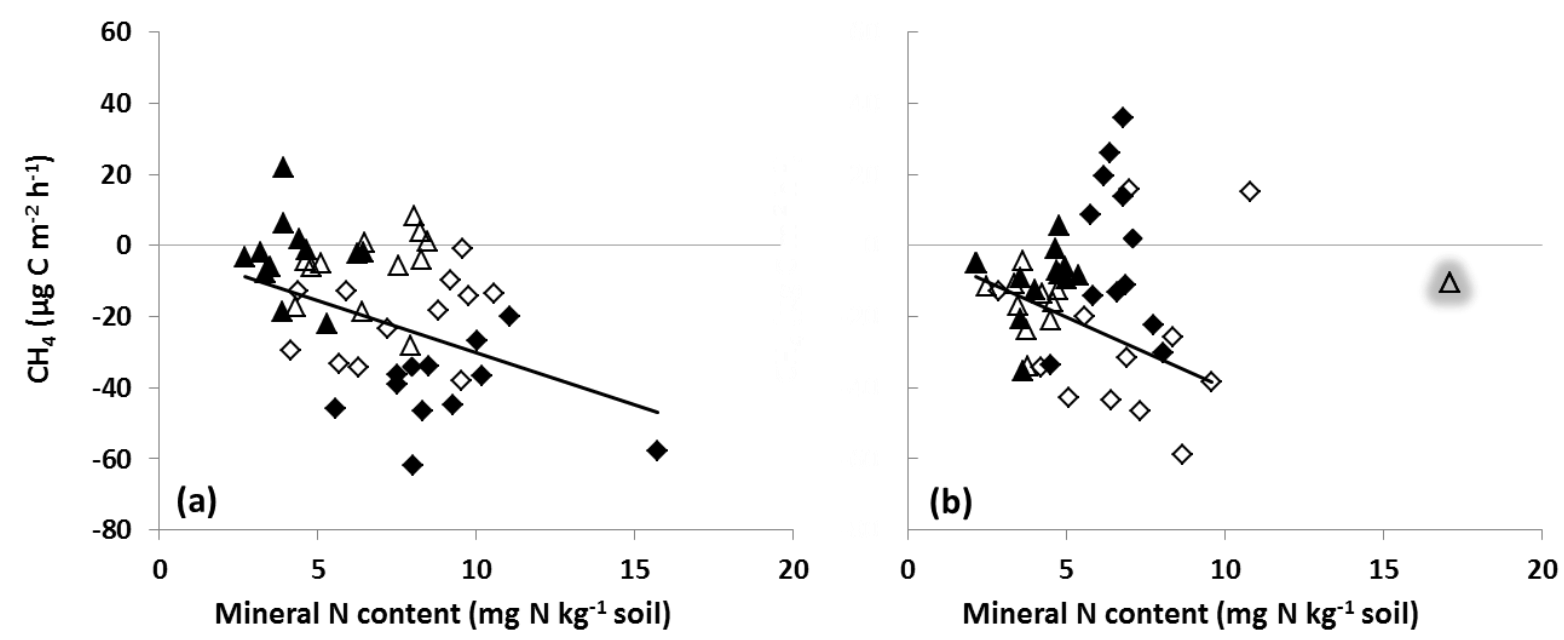

Figure 2.3. Relationship between soil $\mathrm{CH}_{4}$ uptake and soil mineral $\mathrm{N}$ content, using the monthlymeasurement means of four replicate plots per land-use type between December 2012 and December 2013: forest $(\diamond)$, jungle rubber $(\diamond)$, rubber $(\boldsymbol{\Delta})$ and oil palm $(\Delta)$ on the clay Acrisol soil (Pearson correlation: $R=-0.47, P=0.01, n=41$ ) (a) and the loam Acrisol soil (Pearson correlation: $R=-0.52, P<$ $0.01, n=38$ ) (b). Correlations exclude net $\mathrm{CH}_{4}$ emissions (fluxes above 0 ) in both landscapes and an outlier plot of oil palm on the loam Acrisol soil (shaded grey).

soil $\mathrm{CH}_{4}$ uptake with total mineral $\mathrm{N}$ content $\left(R=-0.52, P \leq 0.01, n=38\right.$; Fig. 2.3b) and $\mathrm{NO}_{3}{ }^{-}$ content $(R=-0.75, P \leq 0.01, n=38)$.

\section{Spatial controls of annual $\mathrm{CO}_{2}$ and $\mathrm{CH}_{4}$ fluxes across land-use types within each landscape}

For these correlation analyses, we used all soil physical and biochemical characteristics which are reported in Table A2.1. Apart from the correlations reported here, there were no other significant correlations with any of the tested soil physical and biochemical characteristics. First, analyzing both reference land-use types (forest and jungle rubber) across landscapes, the only significant correlation between annual soil $\mathrm{CO}_{2}$ emissions and soil parameters was with sand content (Spearman's $\rho=-0.51, P=0.08, n=16$ ). However, analyzing for each landscape separately, annual soil $\mathrm{CO}_{2}$ fluxes from the reference land-use types in the loam Acrisol soil correlated with Bray-extractable soil P $(\rho=-0.74, P=0.04, n=8)$. Furthermore, annual soil $\mathrm{CH}_{4}$ fluxes from both reference land-use types across landscapes were correlated with net $\mathrm{N}$ mineralization rates $(\rho=-0.75, P<0.01, n=16)$ and, for each landscape separately, with 
exchangeable Al $(\rho=0.74, P=0.04, n=8$ in the clay Acrisol soil, and $\rho=0.69, P=0.06, n=8$ in the loam Acrisol soil).

Second, analyzing across four land-use types within each landscape, annual soil $\mathrm{CO}_{2}$ fluxes correlated only with soil ${ }^{15} \mathrm{~N}$ natural abundance signatures in the clay Acrisol soil ( $\rho=-0.49, P=0.05 ; n=16)$. In the loam Acrisol soil, annual soil $\mathrm{CO}_{2}$ fluxes correlated with soil organic C $(\rho=0.49, P=0.06, n=16)$, base saturation $(\rho=-0.53, P=0.04, n=16)$, Bray-extractable $\mathrm{P}(\rho=-0.71, P<0.01, n=16)$ and soil ${ }^{15} \mathrm{~N}$ natural abundance signatures $(\rho=-0.60, P=0.02, n=16)$. Annual soil $\mathrm{CH}_{4}$ fluxes across all land-use types in the clay Acrisol soil correlated with net $\mathrm{N}$ mineralization rates $(\rho=-0.52, P=0.04, n=16)$, whereas in the loam Acrisol soil this correlation only showed up after the exclusion of one plot in rubber that had an unusually high net $\mathrm{N}$ mineralization $(\rho=-0.51, P=0.07, n=15)$. Net $\mathrm{N}$ mineralization significantly decreased in rubber that had no fertilization and was intermediate in oil palm that had fertilization, particularly in the clay Acrisol soil (Table A2.1).

\subsection{Discussion}

\section{$\mathrm{CO}_{2}$ and $\mathrm{CH}_{4}$ fluxes from the reference land-use types}

Mean soil $\mathrm{CO}_{2}$ fluxes from our forest sites (Table 2.2) were within the range of reported fluxes (123-228 mg C m $\mathrm{m} \mathrm{h}^{-1}$ ) from tropical rainforests in Asia (Adachi et al., 2005; Ohashi et al., 2008) and Latin America (Davidson et al., 2000; Keller et al., 2005; Koehler et al., 2009; Schwendenmann et al., 2003; Sotta et al., 2006). Compared to measurements conducted in Indonesia, our lowland forests had higher soil $\mathrm{CO}_{2}$ fluxes than a montane forest in Sulawesi at $1000 \mathrm{~m}$ elevation with similar spatially replicated and temporally intensive measurements

(127 $\mathrm{mg} \mathrm{C} \mathrm{m}^{-2} \mathrm{~h}^{-1}$; van Straaten et al., 2011); fluxes were also higher than in the seven partially logged forest sites in Jambi, where measurements were only made once (162 $\mathrm{mg} \mathrm{C} \mathrm{m}^{-2} \mathrm{~h}^{-1}$; Ishizuka et al., 2005). While the difference with this last study may be caused by their one-off sampling, the only other study that measured $\mathrm{CO}_{2}$ fluxes from the same region (which conducted nine measurements spread over 1 year at three plots) reported values that were as low as 33 to $50 \%$ of our measured soil $\mathrm{CO}_{2}$ fluxes (63-94 $\mathrm{mg} \mathrm{C} \mathrm{m}^{-2} \mathrm{~h}^{-1}$; Ishizuka et al., 2002). Such values 
are hard to reconcile with our measurements and those of others in tropical lowland forests, including the measurements by Ishizuka et al. (2005).

Seasonal variation in soil $\mathrm{CO}_{2}$ fluxes from the reference land-use types was driven by changes in soil water content, as suggested by the positive correlation with WFPS in jungle rubber on the loam Acrisol soil (Table 2.3). Other studies conducted in tropical rainforests have shown that seasonal changes in soil $\mathrm{CO}_{2}$ fluxes are often caused by changes in soil water content (e.g., Koehler et al., 2009; Sotta et al., 2007; van Straaten et al., 2011), sometimes in combination with a reduction in solar irradiation caused by clouds during the wet season (Schwendenmann et al., 2003). In tropical forest soils, the relationship of soil $\mathrm{CO}_{2}$ flux with soil water content is curvilinear, with the highest fluxes typically at field capacity ( $p F \sim 2$ or WFPS between 50 and 55 \%; Koehler et al., 2009; Sotta et al., 2007; van Straaten et al., 2011), which explains why WFPS did not show correlation in forests in both landscapes where WFPS (mostly $\geq 60-80 \%$; Fig. 2.1a, b) fluctuated at the top curve of this curvilinear relationship.

In contrast to our first hypothesis, soil texture was not the proximal factor controlling annual soil $\mathrm{CO}_{2}$ fluxes, but instead sand content indirectly affected soil fertility (e.g., Bray-extractable $\mathrm{P}$ ), which, in turn, influenced soil $\mathrm{CO}_{2}$ fluxes. In the reference land-use types, the negative correlation of annual soil $\mathrm{CO}_{2}$ fluxes with the sand contents contrasted with results in the Amazon Basin where sandy Ferralsol soil had higher soil $\mathrm{CO}_{2}$ fluxes than the clay Ferralsol soil (Sotta et al., 2006). In the study by Sotta et al. (2006), annual $\mathrm{CO}_{2}$ emissions were negatively correlated with total soil P content. In our loam Acrisol soil, which had lower soil fertility (i.e., lower Bray-extractable P and base saturation and higher Al saturation) than the clay Acrisol soil (Table A2.1; Allen et al., 2015), there may be strong competition for P such that trees have to allocate more $\mathrm{C}$ to their root or root-mycorrhizal system to obtain this nutrient. At the same study sites, reference land-use types on loam Acrisol soil showed a lower P concentration in the fine roots in the top $0.2 \mathrm{~m}$ of soil than reference land-use types on clay Acrisol soil (Sahner et al., 2015). This strategy of high belowground C investment was reflected in the negative correlation of annual soil $\mathrm{CO}_{2}$ fluxes from the reference land-use types with Bray-extractable $\mathrm{P}$ contents in the loam Acrisol soil.

Mean soil $\mathrm{CH}_{4}$ fluxes from our forest sites (Table 2.2) fall within the range for tropical lowland forests reported by other studies (-6.3 to $-55.9 \mu \mathrm{g} \mathrm{CH}_{4}-\mathrm{C} \mathrm{m}^{-2} \mathrm{~h}^{-1}$; summarized by 
Veldkamp et al., 2013); however, our measured $\mathrm{CH}_{4}$ uptake rates were at the upper end (towards more negative values) of these reported rates and were also higher than the $\mathrm{CH}_{4}$ uptake rates reported for old-growth forests in Jambi, Indonesia (-21.3 to $+4.2 \mu \mathrm{g} \mathrm{CH}_{4}-\mathrm{C} \mathrm{m}^{-2} \mathrm{~h}^{-1}$; Ishizuka et al., 2002).

Seasonal variation in soil $\mathrm{CH}_{4}$ fluxes was strongly controlled by soil water content with higher uptake in the dry season (Fig. 2.1a, b), as shown by the strong positive correlations with WFPS in all land-use types in both landscapes (Table 2.3). Such seasonal changes reflect diffusional limitation on the supply of $\mathrm{CH}_{4}$ to methanotrophs at high WFPS (Keller and Reiners, 1994) and the possible occurrence of anaerobic decomposition, producing $\mathrm{CH}_{4}$, which may partially offset $\mathrm{CH}_{4}$ consumption (Keller and Reiners, 1994; Verchot et al., 2000). Since we measured occasional net $\mathrm{CH}_{4}$ emissions from some reference land-use types (Fig. 2.2d), we cannot exclude this anaerobic $\mathrm{CH}_{4}$ production. High microbial and root activity consume oxygen in the soil, which may contribute to the creation of anaerobic microsites where $\mathrm{CH}_{4}$ can be produced. This may have occurred in the jungle rubber on the loam Acrisol soil, where we detected a positive correlation of soil $\mathrm{CO}_{2}$ fluxes with soil $\mathrm{CH}_{4}$ fluxes (Table 2.3). Positive correlations of soil $\mathrm{CO}_{2}$ fluxes and $\mathrm{CH}_{4}$ fluxes have been reported also for tropical forests (Verchot et al., 2000). In addition to WFPS, soil mineral $\mathrm{N}$ dynamics also influenced the seasonal variation in soil $\mathrm{CH}_{4}$ fluxes. The negative correlations of soil $\mathrm{CH}_{4}$ fluxes with soil $\mathrm{NO}_{3}{ }^{-}$ contents in the forest on the clay Acrisol soil and in the jungle rubber on the loam Acrisol soil (Table 2.3) imply that some of the observed seasonal variability may have been caused by temporal $\mathrm{N}$ limitation of $\mathrm{CH}_{4}$ oxidation (Bodelier and Laanbroek, 2004; Veldkamp et al. 2013).

We found strong indications that $\mathrm{CH}_{4}$ uptake in this converted tropical lowland was both $\mathrm{N}$-limited and affected by high, potentially toxic, exchangeable Al concentrations in the soil. We interpreted negative correlations of annual soil $\mathrm{CH}_{4}$ fluxes from the reference land-use types with net $\mathrm{N}$ mineralization rates (see Sect. 2.3) across landscapes as evidence for $\mathrm{N}$-limited $\mathrm{CH}_{4}$ uptake. Indications of $\mathrm{N}$-limited $\mathrm{CH}_{4}$ uptake have been reported for tropical forests in Panama (Veldkamp et al., 2013) and Ecuador (Wolf et al., 2012), but this is the first time that it was observed on a landscape scale in the tropics. Furthermore, the positive correlations of annual soil $\mathrm{CH}_{4}$ fluxes from the reference land-use types with exchangeable $\mathrm{Al}$ within each landscape reflected the lower $\mathrm{CH}_{4}$ uptake measured at sites with more exchangeable $\mathrm{Al}$ in the soil. Soil $\mathrm{Al}$ 
saturation in our reference land-use types was high (mean values ranged from 61 to $80 \%$; Table A2.1). High $\mathrm{Al}_{3}{ }^{+}$concentrations in the soil solution and higher exchangeable $\mathrm{Al}$ in the soil are known to be toxic for plants, the root growth of which may be inhibited (Ma et al., 2001). Dissolved $\mathrm{Al}_{3}{ }^{+}$can also be toxic for soil microorganisms, and it has been shown that high dissolved $\mathrm{Al}$ concentrations in the soil inhibited $\mathrm{CH}_{4}$ uptake in a temperate forest soil in Japan (Tamai et al., 2003). We are not aware of any study reporting such a relationship for tropical ecosystems, which is not surprising since in most trace gas studies exchangeable $\mathrm{Al}$ in the soil is either not measured or does not reach such high levels as at our sites.

In summary, seasonal variation in soil $\mathrm{CO}_{2}$ fluxes from the reference land-use types were related to soil water content (i.e., jungle rubber in loam Acrisol soil), while the spatial control of annual soil $\mathrm{CO}_{2}$ fluxes across landscapes was related to soil fertility: low Bray-extractable $\mathrm{P}$ concentrations coincided with high annual soil $\mathrm{CO}_{2}$ fluxes from the loam Acrisol soil, which had lower soil fertility than the clay Acrisol soil. Seasonal variation in $\mathrm{CH}_{4}$ fluxes from the reference land-use types were mainly explained by soil water content, although we found indications that temporal $\mathrm{N}$ limitation may also have played a role. Spatial controls of annual soil $\mathrm{CH}_{4}$ fluxes across landscapes were also related to soil fertility, as shown by their negative correlation with soil $\mathrm{N}$ availability, suggesting $\mathrm{N}$ limitation on $\mathrm{CH}_{4}$ uptake, and their positive correlation with exchangeable Al, suggesting Al toxicity towards methanotrophs, which has not yet been reported for tropical ecosystems. These results are in contrast to our first hypothesis - soil texture was not the proximal factor controlling soil $\mathrm{CO}_{2}$ and $\mathrm{CH}_{4}$ fluxes but only did so indirectly through its influence on soil fertility, which, in turn, controlled the spatial variations in these trace gases across our studied landscapes.

\section{Effects of land-use change on $\mathrm{CO}_{2}$ and $\mathrm{CH}_{4}$ fluxes}

Mean soil $\mathrm{CO}_{2}$ fluxes from our rubber plantations (Table 2.2) were on the same order of magnitude as those reported for seven rubber plantations in Jambi (Indonesia) where fluxes were measured once (171 $\mathrm{mg} \mathrm{C} \mathrm{m}^{-2} \mathrm{~h}^{-1}$; Ishizuka et al., 2005), while soil $\mathrm{CO}_{2}$ fluxes from a rubber plantation in a sandy clay loam Nitisol soil in Malaysia with one measurement were

lower (123 mg C m $\mathrm{m}^{-1}$; Adachi et al., 2005). Some other studies reported soil $\mathrm{CO}_{2}$ fluxes that 
are much lower than our measured fluxes: at a rubber plantation on a heavily weathered silty clay soil in China (35 $\mathrm{mg} \mathrm{C} \mathrm{m}^{-2} \mathrm{~h}^{-1}$; Werner et al., 2006) and a rubber plantation in Jambi (Indonesia) with nine measurements (75 $\mathrm{mg} \mathrm{C} \mathrm{m}^{-2} \mathrm{~h}^{-1}$; Ishizuka et al., 2002). Since this last study also reported $33-50 \%$ lower soil $\mathrm{CO}_{2}$ fluxes from forests (see previous section) as well as $50 \%$ lower soil $\mathrm{CO}_{2}$ fluxes from oil palm $\left(51 \mathrm{mg} \mathrm{C} \mathrm{m}^{-2} \mathrm{~h}^{-1}\right.$; Ishizuka et al., 2002) than our measured fluxes from the same region (Table 2.2), we suspect some methodological issues in this study. Mean soil $\mathrm{CO}_{2}$ fluxes from our oil palm sites were comparable with other reported fluxes from five oil palm plantations in Jambi (Indonesia) where fluxes were measured once (98 $\mathrm{mg} \mathrm{C} \mathrm{m}^{-2} \mathrm{~h}^{-1}$; Ishizuka et al., 2005). Lastly, soil $\mathrm{CO}_{2}$ fluxes from an oil palm plantation that were more than double our measured fluxes were reported from a one-time measurement in a sandy clay loam Nitisol soil in Malaysia (222 $\mathrm{mg} \mathrm{C} \mathrm{m}^{-2} \mathrm{~h}^{-1}$; Adachi et al., 2005).

Seasonal variation in soil $\mathrm{CO}_{2}$ fluxes from oil palm was not as pronounced as that in fluxes from rubber (Fig. 2.2a, b). In rubber plantations in loam Acrisol soil, where WFPS were all above $55 \%$ (Fig. 2.1b), the seasonal variation in soil $\mathrm{CO}_{2}$ fluxes reflected the curvilinear relationship of soil $\mathrm{CO}_{2}$ fluxes with WFPS, whereby soil $\mathrm{CO}_{2}$ fluxes typically decline at WFPS larger than about $55 \%$ (e.g., Koehler et al., 2009; Sotta et al., 2007), hence the negative correlation with WFPS (Table 2.3).

The spatial variation in annual soil $\mathrm{CO}_{2}$ fluxes across land-use types reflected the changes in soil organic-matter quality and quantity with changes in land use, as indicated by the negative correlations with soil ${ }^{15} \mathrm{~N}$ natural abundance signatures (see Sect. 2.3) and the positive correlation with soil organic $\mathrm{C}$ content. Soil ${ }^{15} \mathrm{~N}$ signatures in our studied oil palm plantations were significantly higher than in the reference land-use types (i.e., loam Acrisol soil; Table A2.1; Allen et al., 2015), which we interpreted as an indication of the degree of decomposition of soil organic matter. The more decomposed the soil organic matter, the higher the soil ${ }^{15} \mathrm{~N}$ signature, as illustrated by increasing soil ${ }^{15} \mathrm{~N}$ signatures with increasing depth of tropical forest soils (Baldos et al., 2015; Sotta et al., 2008). The more decomposed soil organic matter in the oil palm plantations was probably caused by reduced litter input and lower fine- and coarse-root production compared to the forests (measured at the same sites by Kotowska et al., 2015). The low litter input and root production influenced not only the degree of decomposition of the soil organic matter but also led to strong reductions in soil organic $\mathrm{C}$ stocks of oil palm and rubber 
plantations (measured in the same study region by van Straaten et al., 2015). This may have contributed to the low $\mathrm{CO}_{2}$ emissions, since we also detected a positive correlation of soil $\mathrm{CO}_{2}$ emissions with soil organic C content. Similar findings were reported from the conversion of forest to tree plantations on Acrisol soil in subtropical southern China, where decreases in soil $\mathrm{CO}_{2}$ fluxes were also explained by decreases in annual litterfall and root biomass (Sheng et al., 2010). In addition to changes in soil organic-matter quality, spatial variation in annual soil $\mathrm{CO}_{2}$ fluxes across land-use types in the loam Acrisol soil was also controlled by changes in soil fertility with land-use change, as shown by the fluxes' negative correlations with base saturation and Bray-extractable P (see Sect. 2.3). Conversion of forest or jungle rubber to rubber and oil palm plantations was accompanied by the burning of slashed vegetation, whereby considerable amounts of bases and P could be released from the plant biomass to ashes (Klinge et al., 2004). Input of these nutrients to the soil from the ashes, combined with $\mathrm{P}$ fertilization and liming (particularly in the oil palm plantations), significantly increased soil $\mathrm{pH}$ in both rubber and oil palm as well as base saturation and Bray-extractable P in oil palm (Table A2.1; Allen et al., 2015). The negative correlations of annual soil $\mathrm{CO}_{2}$ fluxes with base saturation and Bray-extractable $\mathrm{P}$ across land-use types suggest that $\mathrm{C}$ allocation to its root-mycorrhizal system may have decreased with increased base cations and $\mathrm{P}$ availability, contributing to the observed decrease in soil $\mathrm{CO}_{2}$ fluxes from oil palm compared to the other land-use types (Table 2.2). In contrast, we could not support the speculation by Ishizuka et al. (2005) that low soil $\mathrm{CO}_{2}$ fluxes from oil palm plantations could be explained by higher soil bulk densities related to intensive management practices since soil bulk densities in these converted land-use types were comparable to the reference land-use types (Table A2.1; Allen et al., 2015).

Mean soil $\mathrm{CH}_{4}$ fluxes from rubber plantations (Table 2.2) were comparable with those reported for a rubber plantation in southwest China (-5.7 $\mu \mathrm{g} \mathrm{CH}_{4}-\mathrm{C} \mathrm{m}^{-2} \mathrm{~h}^{-1}$; Werner et al., 2006) and for seven rubber plantations in Jambi (Indonesia) measured only once $\left(-5.8 \mu \mathrm{g} \mathrm{CH}_{4}-\mathrm{C} \mathrm{m}^{-2}\right.$ $\mathrm{h}^{-1}$; Ishizuka et al., 2005). From the oil palm plantations, mean soil $\mathrm{CH}_{4}$ fluxes (Table 2.2) were comparable with those reported for five oil palm plantations in Jambi (Indonesia), where fluxes were measured only once (-20.1 $\mu \mathrm{g} \mathrm{CH}_{4}-\mathrm{C} \mathrm{m}^{-2} \mathrm{~h}^{-1}$; Ishizuka et al., 2005), but larger (or higher $\mathrm{CH}_{4}$ uptake rate) than the values reported for an oil palm plantation in Jambi with one measurement (-4.2 $\mu \mathrm{g}$ CH4-C m-2 h-1; Ishizuka et al., 2002). 
As was the case for the reference land-use types, seasonal variation in soil $\mathrm{CH}_{4}$ fluxes from the converted land-use types was also controlled by WFPS (Table 2.3), and the possible mechanisms were the same (see previous section). Moreover, strong negative correlations of soil $\mathrm{CH}_{4}$ uptake with total mineral $\mathrm{N}$ (Fig. 2.3) and $\mathrm{NO}_{3}{ }^{-}$contents across all land-use types (see Sect. 2.3), with total mineral $\mathrm{N}$ being lowest in the converted land-use types (Table 2.1), also suggest temporal N limitation on methanotrophic activity (Veldkamp et al., 2013) that may have contributed to the decrease in $\mathrm{CH}_{4}$ uptake in the converted land-use types (Fig. 2.2c, d; Table 2.2).

The negative correlations of annual soil $\mathrm{CH}_{4}$ fluxes with net $\mathrm{N}$ mineralization rates across land-use types further suggest $\mathrm{N}$ limitation on $\mathrm{CH}_{4}$ uptake, as indicated by the lowest $\mathrm{CH}_{4}$ uptake in the converted land-use types (Table 2.2) that had the lowest (i.e., rubber with no $\mathrm{N}$ fertilization) to intermediate (i.e., oil palm with $\mathrm{N}$ fertilization) net $\mathrm{N}$ mineralization rates. The results from the fertilization experiment in the oil palm sites that showed inhibition of $\mathrm{CH}_{4}$ uptake in the fertilized spot (chamber location b; Table A2.3) within 6 weeks following fertilizer application (Fig. A2.1) were probably caused by salt effect, as has been observed in a fertilization experiment in tropical pastures (Veldkamp et al., 2001). However, this $\mathrm{CH}_{4}$ inhibition following fertilizer application did not influence our annual flux estimates because of the negligible area coverage of the fertilized spots $(\sim 1.3 \%$ of 1 ha) and its short-term effect (12\% of 1 year).

In summary, soil $\mathrm{CO}_{2}$ fluxes decreased only in oil palm and not in rubber, which partly supports our second hypothesis. These converted land-use types showed a decrease in soil $\mathrm{CH}_{4}$ uptake, which supports our second hypothesis. Seasonality of soil $\mathrm{CO}_{2}$ and $\mathrm{CH}_{4}$ fluxes in the converted land-use types appeared to be controlled by the same factors as in the reference land-use types. The strong decrease in soil $\mathrm{CO}_{2}$ fluxes from the oil palm was probably caused by a combination of strongly decomposed soil organic matter and low soil carbon stocks (caused by the low input of litterfall and low fine-root production) and possibly by low $\mathrm{C}$ allocation to the root or the root-mycorrhizal system (due to the improved base cations and $\mathrm{P}$ availability from liming and $\mathrm{P}$ fertilization). Reduction in annual $\mathrm{CH}_{4}$ uptake in the converted land-use types was primarily caused by the decrease in soil $\mathrm{N}$ availability in these converted land-use types. 


\subsection{Consequences of land-use change for soil trace gas fluxes}

Our study shows that land-use change had a profound effect on the soil-atmosphere fluxes of the trace gases $\mathrm{CO}_{2}$ and $\mathrm{CH}_{4}$, with reduced soil $\mathrm{CO}_{2}$ fluxes from oil palm plantations and reduced soil $\mathrm{CH}_{4}$ uptake in both rubber and oil palm plantations. The reduced soil $\mathrm{CO}_{2}$ fluxes in the oil palm should not be interpreted as reduced net ecosystem emissions because we did not measure the net $\mathrm{CO}_{2}$ uptake by the vegetation and the changes in soil and vegetation carbon stocks. Rather the strong decrease in soil $\mathrm{CO}_{2}$ fluxes from oil palm is a reflection of the present belowground carbon dynamics in this land-use type. Due to decreases in litterfall and fine-root production (Kotowska et al., 2015) as well as frond management practice (stacking fronds in interrows) that reduced fresh litter input in the whole area, soil organic C stocks in these oil palm plantations decreased over time (van Straaten et al., 2015), reflecting the reductions in soil $\mathrm{CO}_{2}$ emissions.

Our estimate of the decrease in $\mathrm{CH}_{4}$ uptake resulting from conversion of forest or jungle rubber to rubber and oil palm in these landscapes was about $2 \mathrm{~kg} \mathrm{CH}_{4}-\mathrm{C} \mathrm{ha}^{-1} \mathrm{yr}^{-1}$ (based on the average of the values in Table 2.2). If we multiply this with $0.52 \mathrm{Mha}$, the increase in areal coverage of oil palm and rubber plantations in Jambi from 1996 to 2011 (BPS, 2012), this suggests that the capacity of the province of Jambi to remove this potent greenhouse gas from the atmosphere has decreased by about $1040 \mathrm{Mg} \mathrm{CH}_{4}-\mathrm{C} \mathrm{yr}^{-1}$ as a result of this land-use conversion. This calculation does not take into account land-use changes that occurred in the peatlands. Finally, we detected important soil fertility controls on trace gas exchange in this converted tropical landscape on highly weathered Acrisol soils, including the controls of base cation and $\mathrm{P}$ availability on annual soil $\mathrm{CO}_{2}$ fluxes and $\mathrm{N}$ availability and $\mathrm{Al}$ toxicity on annual soil $\mathrm{CH}_{4}$ fluxes. Such controls on the landscape scale have not yet been reported, and thus we stress the importance of conducting landscape-scale studies as field studies on a few small plots or laboratory-based studies may not be able to detect such important controls.

Acknowledgements. We thank the village leaders, local plot owners, PT REKI, PT Perkebunan Nusantara VI, and Bukit Duabelas National Park for granting us access to and use of their properties. This study was financed by the Deutsche Forschungsgemeinschaft (DFG) as part of 
the project A05 in the framework of the German-Indonesian Collaborative Research Center 990: Ecological and Socioeconomic Function of Tropical Lowland Rainforest Transformation Systems. We are especially grateful to our Indonesian assistants, Edward Januarlin Siahaan, Nelson Apriadi Silalahi, Ardi, Fahrurrozy and Edi, as well as all the rangers of the protected forest areas. We also acknowledge the other members of project A05 (Allen et al., 2015; Kurniawan et al., unpublished data) for the soil physical and biochemical data (Table A2.1); projects B04 (Kotowska et al., 2015), B06 (Rembold et al., unpublished data) and B07 (Sahner et al., 2015) for the litterfall and root production, root nutrient concentrations and vegetation characteristics (Table A2.2); and project $\mathrm{C} 07$ (Euler et al., unpublished data) for information on land-use history. We also thank Norman Loftfield, Oliver van Straaten, Andrea Bauer, Kerstin Langs and Martina Knaust (Georg August University Göttingen, Germany) for their assistance with laboratory analyses. This study was conducted using the research permits (210/SIP/FRP/SM/VI/2012 and 45/EXT/SIP/FRP/SM/V/2013) issued by the Ministry of Research and Technology of Indonesia (RISTEK) and the collection permits (2703/IPH.1/KS.02/XI/2012 and S.13/KKH-2/2013) recommended by the Indonesian Institute of Sciences (LIPI) and issued by the Ministry of Forestry of Indonesia (PHKA). 


\section{Appendix}

\section{Soil sampling and analysis}

Soil samples were taken from 10 subplots per plot that were randomly selected and at least $5 \mathrm{~m}$ distance from the plot's border. Soil characteristics for each replicate plot were the average of the 10 subplots. Soil sampling was conducted between June 2013 and December 2013. Soil samples were taken at various depth intervals down to $2 \mathrm{~m}$, and we report here the values from the top depth interval $(0-0.1 \mathrm{~m})$, except for soil texture, which we report for the entire $2 \mathrm{~m}$. Soil texture was analyzed using the wet sieving and pipette methods. Soil bulk density was measured using the core method. Soil $\mathrm{pH}\left(\mathrm{H}_{2} \mathrm{O}\right)$ was analyzed in a $1: 4$ soil-to-water ratio. Soil organic $\mathrm{C}$ and total $\mathrm{N}$ concentrations were analyzed from air-dried, sieved $(2 \mathrm{~mm})$ and ground samples using a $\mathrm{CN}$ analyzer (Vario EL Cube, Elementar Analysis Systems GmbH, Hanau, Germany). Air-dried and sieved soils were used to determine effective cation exchange capacity (ECEC) by percolating with unbuffered $1 \mathrm{~mol} \mathrm{~L}^{-1} \mathrm{NH}_{4} \mathrm{Cl}$, and cations ( $\mathrm{Ca}, \mathrm{Mg}, \mathrm{K}, \mathrm{Na}, \mathrm{Al}, \mathrm{Fe}$, and $\mathrm{Mn}$ ) were measured in percolate using an inductively coupled plasma-atomic emission spectrometer (iCAP 6300 Duo VIEW ICP Spectrometer, Thermo Fischer Scientific GmbH, Dreieich, Germany). Base and aluminum saturation were calculated as the percentage of exchangeable base cations and aluminum of the ECEC. Extractable P was determined using the Bray 2 method, which is typically used for acidic tropical soils. For soil ${ }^{15} \mathrm{~N}$ natural abundance signatures, ground soil samples were analyzed using isotope ratio mass spectrometry (IRMS; Delta Plus, Finnigan MAT, Bremen, Germany). The net $\mathrm{N}$ mineralization rate was measured in two subplots per plot that were at least $10 \mathrm{~m}$ from the plot's border, using the buried-bag method on intact soil cores incubated in situ for 7 days. This was conducted between January 2013 and May 2013 during the rainy season. The field extraction of the soil with $0.5 \mathrm{M} \mathrm{K}_{2} \mathrm{SO}_{4}$, analysis of $\mathrm{NH}_{4}{ }^{+}$and $\mathrm{NO}_{3}{ }^{-}$ concentrations, and calculation of rate are used are the same as described in our earlier work (Arnold et al., 2008). The net $\mathrm{N}$ mineralization rate for each plot was the average of two subplots. 
Table A2.1. Mean $( \pm$ SE, $n=4)$ soil physical and biochemical characteristics in the top $0.10 \mathrm{~m}$ depth (except for the clay content, $0-2 \mathrm{~m}$ depth with $n=3$ ) for different land-use types within each soil landscape in Jambi, Sumatra, Indonesia. Means followed by different lowercase letters indicate significant differences among land-use types within each soil landscape and different capital letters indicate significant differences between soil landscapes within a land-use type (linear mixed-effect models with Fisher's LSD test at $P \leq 0.05$ and marginally significant at * $P \leq$ 0.09). Soil characteristics were measured by Allen et al. (2015). Soil sampling and analysis are described in the Appendix.

\begin{tabular}{|c|c|c|c|c|}
\hline \multirow[t]{2}{*}{ Soil characteristics } & \multicolumn{4}{|c|}{ Land use } \\
\hline & Forest & Jungle rubber & Rubber & Oil palm \\
\hline \multicolumn{5}{|l|}{ clay Acrisol soil } \\
\hline Clay $(0-0.5 \mathrm{~m})(\%)$ & $31.4 \pm 5.4^{\mathrm{a}}$ & $47.2 \pm 12.40^{\mathrm{a}}$ & $42.4 \pm 3.1^{\mathrm{a}}$ & $59.7 \pm 5.2^{\mathrm{a}, \mathrm{A}}$ \\
\hline Clay $(0.5-1.0 \mathrm{~m})(\%)$ & $34.9 \pm 9.0^{b^{*}}$ & $51.4 \pm 12.6^{\mathrm{ab}^{*}}$ & $36.8 \pm 8.00^{b^{*}}$ & $69.7 \pm 4.8^{\mathrm{a}^{*} \mathrm{~A}}$ \\
\hline Clay $(1.0-1.5 \mathrm{~m})(\%)$ & $39.0 \pm 13.0^{\mathrm{a}}$ & $62.8 \pm 12.6^{\mathrm{a}}$ & $40.8 \pm 10.3^{\mathrm{a}}$ & $62.8 \pm 3.6^{\mathrm{a}, \mathrm{A}}$ \\
\hline Clay $(1.5-2.0 \mathrm{~m})(\%)$ & $41.3 \pm 11.2^{\mathrm{a}}$ & $46.6 \pm 16.2^{\mathrm{a}}$ & $36.5 \pm 10.8^{\mathrm{a}}$ & $63.3 \pm 6.1^{\mathrm{a}, \mathrm{A}}$ \\
\hline Sand $(0-0.10 \mathrm{~m})(\%)$ & $36 \pm 11^{\mathrm{a}}$ & $27 \pm 20^{\mathrm{a}}$ & $35 \pm 7^{\mathrm{a}}$ & $11 \pm 2^{\mathrm{a}, \mathrm{B}^{*}}$ \\
\hline Bulk density $\left(\mathrm{g} \mathrm{cm}^{-3}\right)$ & $1.0 \pm 0.1^{\mathrm{a}}$ & $0.8 \pm 0.1^{\mathrm{a}}$ & $0.9 \pm 0.1^{\mathrm{a}}$ & $0.9 \pm 0.1^{\mathrm{a}, \mathrm{B}}$ \\
\hline $\mathrm{pH}\left(1: 4 \mathrm{H}_{2} \mathrm{O}\right)$ & $4.2 \pm 0.4^{\mathrm{b}}$ & $4.5 \pm 0.0^{\mathrm{a}, \mathrm{A}}$ & $4.5 \pm 0.1^{\mathrm{a}}$ & $4.4 \pm 0.1^{\mathrm{a}}$ \\
\hline Soil organic $\mathrm{C}\left(\mathrm{kg} \mathrm{C} \mathrm{m}^{-2}\right)$ & $3.3 \pm 0.5^{\mathrm{a}}$ & $4.3 \pm 0.4^{\mathrm{a}, \mathrm{A}}$ & $2.8 \pm 0.4^{\mathrm{a}}$ & $3.5 \pm 0.2^{\mathrm{a}, \mathrm{A}}$ \\
\hline Total $\mathrm{N}\left(\mathrm{g} \mathrm{N} \mathrm{m}^{-2}\right)$ & $263.4 \pm 67.1^{\mathrm{a}}$ & $331.4 \pm 34.1^{\mathrm{a}, \mathrm{A}}$ & $198.4 \pm 32.5^{\mathrm{a}}$ & $260.2 \pm 22.6^{\mathrm{a}, \mathrm{A}}$ \\
\hline $\mathrm{C}: \mathrm{N}$ ratio & $13.1 \pm 1.3^{\mathrm{a}}$ & $13.0 \pm 0.3^{\mathrm{a}}$ & $14.3 \pm 0.6^{\mathrm{a}, \mathrm{A}}$ & $13.5 \pm 0.2^{\mathrm{a}}$ \\
\hline Effective cation exchange capacity $\left(\mathrm{cmol}_{\mathrm{c}} \mathrm{kg}^{-1}\right)$ & $9.4 \pm 4.1^{\mathrm{a}}$ & $12.4 \pm 2.6^{\mathrm{a}, \mathrm{A}}$ & $7.1 \pm 2.2^{\mathrm{a}}$ & $7.8 \pm 0.8^{\mathrm{a}, \mathrm{A}}$ \\
\hline Base saturation $(\%)$ & $23 \pm 6^{\mathrm{a}, \mathrm{A}}$ & $23 \pm 6^{\mathrm{a}}$ & $20 \pm 3^{\mathrm{a}}$ & $38 \pm 7^{\mathrm{a}}$ \\
\hline Aluminum saturation $(\%)$ & $61 \pm 3^{\mathrm{ab}, \mathrm{B}}$ & $71 \pm 6^{\mathrm{a}}$ & $73 \pm 4^{\mathrm{a}}$ & $53 \pm 7^{b}$ \\
\hline Bray-extractable phosphorus $\left(\mathrm{g} \mathrm{P} \mathrm{m}^{-2}\right)$ & $1.4 \pm 0.1^{\mathrm{ab}, \mathrm{A}}$ & $0.8 \pm 0.1^{\mathrm{bc}}$ & $0.4 \pm 0.0^{\mathrm{c}}$ & $4.7 \pm 1.5^{\mathrm{a}, \mathrm{A}^{*}}$ \\
\hline${ }^{15} \mathrm{~N}$ natural abundance $(\%)$ & $4.5 \pm 0.0^{\mathrm{a}}$ & $4.0 \pm 0.3^{\mathrm{a}}$ & $4.6 \pm 0.4^{\mathrm{a}}$ & $5.2 \pm 0.4^{\mathrm{a}}$ \\
\hline Net $\mathrm{N}$ mineralization $\left(\mathrm{mg} \mathrm{N} \mathrm{kg}^{-1} \mathrm{~d}^{-1}\right)$ & $1.2 \pm 0.3^{\mathrm{a}}$ & $0.5 \pm 0.0^{b}$ & $0.5 \pm 0.2^{b}$ & $0.9 \pm 0.2^{\mathrm{ab}}$ \\
\hline \multicolumn{5}{|l|}{ loam Acrisol soil } \\
\hline Clay $(0-0.5 \mathrm{~m})(\%)$ & $26.0 \pm 2.6^{\mathrm{a}}$ & $30.6 \pm 4.6^{\mathrm{a}}$ & $37.3 \pm 10.3^{\mathrm{a}}$ & $33.4 \pm 2.2^{\mathrm{a}, \mathrm{B}}$ \\
\hline Clay $(0.5-1.0 \mathrm{~m})(\%)$ & $28.7 \pm 4.8^{\mathrm{a}}$ & $38.8 \pm 9.0^{\mathrm{a}}$ & $45.1 \pm 11.3^{\mathrm{a}}$ & $41.0 \pm 3.1^{\mathrm{a}, \mathrm{B}}$ \\
\hline Clay $(1.0-1.5 \mathrm{~m})(\%)$ & $33.3 \pm 7.56^{\mathrm{a}}$ & $42.4 \pm 9.9^{\mathrm{a}}$ & $46.1 \pm 9.9^{\mathrm{a}}$ & $43.3 \pm 2.8^{\mathrm{a}, \mathrm{B}}$ \\
\hline
\end{tabular}




\begin{tabular}{lllll} 
Clay $(1.5-2.0 \mathrm{~m})(\%)$ & $37.3 \pm 8.7^{\mathrm{a}}$ & $44.5 \pm 10.0^{\mathrm{a}}$ & $43.4 \pm 6.5^{\mathrm{a}}$ & $47.6 \pm 4.5^{\mathrm{a}, \mathrm{B}}$ \\
Sand $(0-0.10 \mathrm{~m})(\%)$ & $39 \pm 8^{\mathrm{a}}$ & $42 \pm 19^{\mathrm{a}}$ & $26 \pm 13^{\mathrm{a}}$ & $43 \pm 14^{\mathrm{a}, \mathrm{A}^{*}}$ \\
Bulk density $\left(\mathrm{g} \mathrm{cm}^{-3}\right)$ & $1.0 \pm 0.0^{\mathrm{ab}}$ & $0.9 \pm 0.0^{\mathrm{b}}$ & $1.1 \pm 0.1^{\mathrm{a}}$ & $1.1 \pm 0.1^{\mathrm{a}, \mathrm{A}}$ \\
$\mathrm{pH}\left(1: 4 \mathrm{H}_{2} \mathrm{O}\right)$ & $4.3 \pm 0.0^{\mathrm{b}^{*}}$ & $4.3 \pm 0.0^{\mathrm{b}^{*}, \mathrm{~B}}$ & $4.5 \pm 0.1^{\mathrm{a} *}$ & $4.5 \pm 0.1^{\mathrm{a}^{*}}$ \\
Soil organic C $\left(\mathrm{kg} \mathrm{C} \mathrm{m}^{-2}\right)$ & $2.6 \pm 0.2^{\mathrm{a}}$ & $2.7 \pm 0.3^{\mathrm{a}, \mathrm{B}}$ & $2.0 \pm 0.3^{\mathrm{a}}$ & $1.8 \pm 0.2^{\mathrm{a}, \mathrm{B}}$ \\
Total N $\left(\mathrm{g} \mathrm{m}^{-2}\right)$ & $182.9 \pm 10.8^{\mathrm{a}}$ & $186.19 \pm 11.0^{\mathrm{a}, \mathrm{B}}$ & $172.6 \pm 23.8^{\mathrm{a}}$ & $145.0 \pm 13.5^{\mathrm{a}, \mathrm{B}}$ \\
C:N ratio & $14.3 \pm 0.2^{\mathrm{a}}$ & $13.7 \pm 0.8^{\mathrm{a}}$ & $11.7 \pm 0.7^{\mathrm{b}, \mathrm{B}}$ & $12.5 \pm 0.5^{\mathrm{ab}}$ \\
Effective cation exchange capacity $\left(\mathrm{cmol}_{\mathrm{c}} \mathrm{kg}^{-1}\right)$ & $4.5 \pm 0.5^{\mathrm{a}}$ & $4.1 \pm 0.8^{\mathrm{a}, \mathrm{B}}$ & $4.6 \pm 0.5^{\mathrm{a}}$ & $4.0 \pm 0.8^{\mathrm{a}, \mathrm{B}}$ \\
Base saturation $(\%)$ & $11 \pm 1^{\mathrm{b}^{*}, \mathrm{~B}}$ & $16 \pm 2^{\mathrm{ab}}$ & $21 \pm 8^{\mathrm{ab}}$ & $28 \pm 5^{\mathrm{b}^{*}}$ \\
Aluminum saturation $(\%)$ & $80 \pm 1^{\mathrm{a}, \mathrm{A}}$ & $78 \pm 2^{\mathrm{a}}$ & $73 \pm 8^{\mathrm{a}}$ & $67 \pm 5^{\mathrm{a}}$ \\
Bray-extractable phosphorus $\left(\mathrm{g} \mathrm{P} \mathrm{m}^{-2}\right)$ & $0.5 \pm 0.1^{\mathrm{a}, \mathrm{B}}$ & $0.7 \pm 0.1^{\mathrm{a}}$ & $0.5 \pm 0.1^{\mathrm{a}}$ & $0.8 \pm 0.1^{\mathrm{a}, \mathrm{B}^{*}}$ \\
${ }^{15} \mathrm{~N}$ natural abundance $(\%)$ & $4.3 \pm 0.2^{\mathrm{b}}$ & $4.5 \pm 0.1^{\mathrm{b}}$ & $5.0 \pm 0.4^{\mathrm{ab}}$ & $5.4 \pm 0.3^{\mathrm{a}}$ \\
Net N mineralization $\left(\mathrm{mg} \mathrm{N} \mathrm{kg}^{-1} \mathrm{~d}^{-1}\right)$ & $0.8 \pm 0.2^{\mathrm{a}}$ & $0.7 \pm 0.1^{\mathrm{a}}$ & $0.7 \pm 0.3^{\mathrm{a}}$ & $0.5 \pm 0.2^{\mathrm{a}}$ \\
\hline
\end{tabular}


Table A2.2. Plantation age and mean $( \pm \mathrm{SE}, n=4)$ tree density, tree height, basal area, diameter at breast height $(\mathrm{DBH})$ of trees with $\geq 0.10 \mathrm{~m}$ DBH and the most common tree species for different land-use types within each soil landscape in Jambi, Sumatra, Indonesia.

\begin{tabular}{|c|c|c|c|c|c|c|}
\hline Land-use type & $\begin{array}{l}\text { Age range } \\
\text { (years) }\end{array}$ & $\begin{array}{l}\text { Tree } \\
\text { density } \\
\left(\mathrm{n} \mathrm{ha}^{-1}\right)^{\mathrm{a}}\end{array}$ & $\begin{array}{l}\text { Tree height } \\
(\mathrm{m})^{\mathrm{a}}\end{array}$ & $\begin{array}{l}\text { Basal area } \\
\left(\mathrm{m}^{2} \mathrm{ha}^{-1}\right)^{\mathrm{a}}\end{array}$ & $\begin{array}{l}\mathrm{DBH} \\
(\mathrm{cm})^{\mathrm{a}}\end{array}$ & Most common tree species ${ }^{b}$ \\
\hline \multicolumn{7}{|c|}{ clay Acrisol soil } \\
\hline Forest & $\begin{array}{l}\text { not determined } \\
\text { (ND) }\end{array}$ & $471 \pm 31$ & $17.0 \pm 0.5$ & $29.4 \pm 1.7$ & $23.0 \pm 0.4$ & $\begin{array}{l}\text { Archidendron sp., Baccaurea } \\
\text { spp., Ochanostachys sp. }\end{array}$ \\
\hline Jungle rubber & ND & $685 \pm 72$ & $15.2 \pm 0.3$ & $21.1 \pm 1.4$ & $17.3 \pm 0.6$ & $\begin{array}{l}\text { Artocarpus spp., Endospermum } \\
\text { sp., Hevea sp., Macaranga spp. }\end{array}$ \\
\hline Rubber & $7-16$ & $497 \pm 15$ & $13.4 \pm 0.1$ & $10.0 \pm 1.4$ & $15.2 \pm 0.7$ & Hevea brasiliensis \\
\hline Oil palm & $9-13$ & $134 \pm 6$ & $4.0 \pm 0.3$ & not applicable (NA) & NA & Elaeis guineensis \\
\hline \multicolumn{7}{|c|}{ loam Acrisol soil } \\
\hline Forest & ND & $658 \pm 26$ & $20.0 \pm 0.6$ & $30.7 \pm 1.0$ & $21.0 \pm 0.5$ & $\begin{array}{l}\text { Aporosa spp., Burseraceae } \\
\text { spp., Dipterocarpaceae spp., } \\
\text { Fabaceae spp., Gironniera } \\
\text { spp., Myrtaceae spp., } \\
\text { Plaquium spp., Porterandia } \\
\text { sp., Shorea spp. }\end{array}$ \\
\hline Jungle rubber & ND & $525 \pm 60$ & $14.0 \pm 0.2$ & $16.6 \pm 0.4$ & $16.8 \pm 0.5$ & $\begin{array}{l}\text { Alstonia spp., Artocarpus spp., } \\
\text { Fabaceae sp., Hevea sp., } \\
\text { Macaranga spp., Porterandia } \\
\text { sp., Sloetia sp. }\end{array}$ \\
\hline Rubber & $14-17$ & $440 \pm 81$ & $13.4 \pm 0.5$ & $12.2 \pm 1.6$ & $17.8 \pm 1.2$ & Hevea brasiliensis \\
\hline Oil palm & $12-16$ & $140 \pm 4$ & $4.9 \pm 0.6$ & NA & NA & Elaeis guineensis \\
\hline
\end{tabular}

${ }^{\mathrm{a}}$ Kotowska et al. (2015). ${ }^{\mathrm{b}}$ Rembold et al. (unpublished data), based on trees found in five subplots ( $5 \mathrm{~m} \times 5 \mathrm{~m}$ ) of each replicate plot (50 m x $50 \mathrm{~m}$ ) which had $\geq 20$ individuals, except in the case of Fabaceae spp. which had $\leq 20$ individuals. 
Table A2.3. Mean ( $\pm \mathrm{SE}, n=3$ oil palm trees) soil $\mathrm{CO}_{2}$ and $\mathrm{CH}_{4}$ fluxes from three different chamber locations during a fertilization in three oil palm plantations within each soil landscape, measured 6 to 11 times during 3-8.5 weeks following fertilization. Means followed by different letters indicate significant differences among chamber locations within each oil palm plantation site (linear mixed-effect models with Fisher's LSD test at $P \leq 0.05$ ). Chamber locations a, b and c were placed at $0.3,0.8$, and 4-4.5 m, respectively, from each of the three trees at each oil palm plantation site. Smallholders fertilized the area around the base of each tree about $0.8-1 \mathrm{~m}$ from the tree base, and thus chamber location $\mathrm{b}$ was on this fertilized area and chamber location c serves as the reference chamber not receiving any fertilizer. The same fertilization rate and form as applied by the smallholders were used in these studied oil palm plantations, described in Sect. 2.2 " $\mathrm{CO}_{2}$ and $\mathrm{CH}_{4}$ flux measurement".

\begin{tabular}{|c|c|c|c|}
\hline Oil palm plantation site & $\begin{array}{l}\text { Chamber } \\
\text { location }\end{array}$ & $\begin{array}{l}\mathrm{CO}_{2} \text { fluxes } \\
\left(\mathrm{mg} \mathrm{C} \mathrm{m}^{-2} \mathrm{~h}^{-1}\right)\end{array}$ & $\begin{array}{l}\mathrm{CH}_{4} \text { fluxes } \\
\left(\mu \mathrm{g} \mathrm{C} \mathrm{m}^{-2} \mathrm{~h}^{-1}\right)\end{array}$ \\
\hline \multicolumn{4}{|l|}{ clay Acrisol soil } \\
\hline \multirow[t]{3}{*}{1} & $\mathrm{a}$ & $272.83 \pm 36.68^{a}$ & $-23.66 \pm 2.56^{b}$ \\
\hline & $\mathrm{b}$ & $218.25 \pm 25.91^{b}$ & $-12.61 \pm 5.12^{\mathrm{a}}$ \\
\hline & $\mathrm{c}$ & $103.56 \pm 11.72^{c}$ & $-16.66 \pm 8.68^{a b}$ \\
\hline \multirow[t]{3}{*}{2} & $\mathrm{a}$ & $226.16 \pm 38.17^{\mathrm{a}}$ & $-28.44 \pm 1.48^{b}$ \\
\hline & $\mathrm{b}$ & $246.39 \pm 42.80^{\mathrm{a}}$ & $-6.64 \pm 2.07^{\mathrm{a}}$ \\
\hline & c & $86.04 \pm 7.83^{b}$ & $-10.60 \pm 5.29^{a}$ \\
\hline \multirow[t]{3}{*}{3} & $\mathrm{a}$ & $222.56 \pm 72.49^{b}$ & $-8.13 \pm 4.77^{\mathrm{a}}$ \\
\hline & $\mathrm{b}$ & $311.63 \pm 89.87^{\mathrm{a}}$ & $-10.38 \pm 3.61^{\mathrm{a}}$ \\
\hline & $\mathrm{c}$ & $105.49 \pm 12.06^{\mathrm{c}}$ & $-14.49 \pm 2.03^{\mathrm{a}}$ \\
\hline \multicolumn{4}{|l|}{ loam Acrisol soil } \\
\hline \multirow[t]{3}{*}{1} & $\mathrm{a}$ & $334.67 \pm 32.12^{a}$ & $-14.00 \pm 3.31^{b}$ \\
\hline & $\mathrm{b}$ & $378.47 \pm 50.97^{\mathrm{a}}$ & $-4.12 \pm 2.24^{\mathrm{a}}$ \\
\hline & $\mathrm{c}$ & $160.35 \pm 20.48^{b}$ & $-18.53 \pm 1.32^{b}$ \\
\hline \multirow[t]{3}{*}{2} & a & $271.35 \pm 17.31^{\mathrm{a}}$ & $-13.18 \pm 1.22^{\mathrm{a}}$ \\
\hline & $\mathrm{b}$ & $233.27 \pm 18.98^{b}$ & $-8.63 \pm 0.52^{\mathrm{a}}$ \\
\hline & $\mathrm{c}$ & $127.66 \pm 17.13^{\mathrm{c}}$ & $-19.47 \pm 5.08^{b}$ \\
\hline \multirow[t]{3}{*}{3} & $\mathrm{a}$ & $240.81 \pm 23.12^{\mathrm{a}}$ & $-28.13 \pm 3.40^{b}$ \\
\hline & $\mathrm{b}$ & $243.92 \pm 24.23^{\mathrm{a}}$ & $-10.34 \pm 2.70^{\mathrm{a}}$ \\
\hline & $\mathrm{c}$ & $136.55 \pm 19.08^{b}$ & $-29.41 \pm 2.39^{b}$ \\
\hline
\end{tabular}




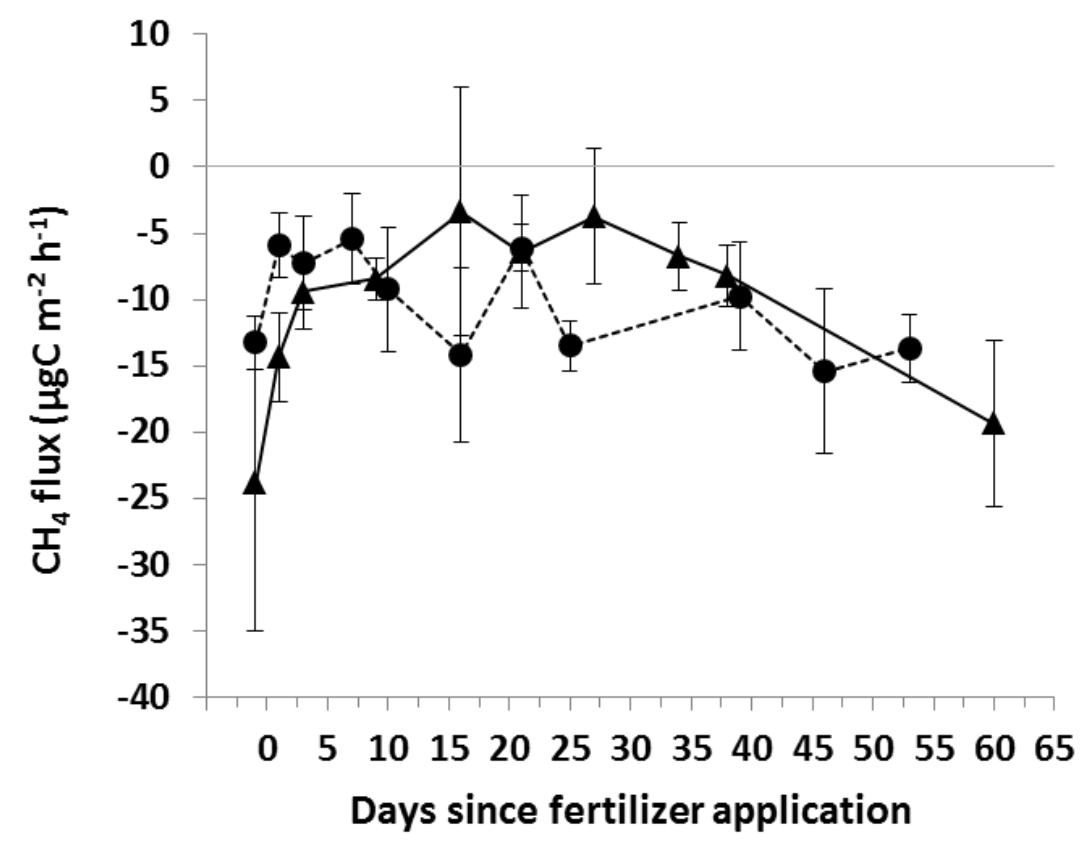

Figure A2.1. Mean $\left( \pm\right.$ SE, $n=3$ oil palm trees) soil $\mathrm{CH}_{4}$ fluxes during a fertilization at one oil palm plantation site in the clay Acrisol soil $(\mathbf{\Lambda})$ and loam Acrisol soil $(\bullet)$. Smallholders fertilized the area around the base of each tree at about $0.8-1 \mathrm{~m}$ from the tree base, and fluxes were measured on this fertilized location (chamber location b) at the same rate and form that smallholders applied in these oil palm plantations (described in Sect. 2.2 " $\mathrm{CO}_{2}$ and $\mathrm{CH}_{4}$ flux measurement"). 


\section{References}

Adachi, M., Bekku, Y. S., Konuma, A., Kadir, W. R., Okuda, T., and Koizumi, H.: Required sample size for estimating soil respiration rates in large areas of two tropical forests and of two types of plantation in Malaysia, Forest Ecol. Manag., 210, 455-459, 2005.

Allen, K., Corre, M. D., Tjoa, A., and Veldkamp, E.: Soil nitrogen-cycling responses to conversion of lowland forests to oil palm and rubber plantations in Sumatra, Indonesia, PLoS ONE, 10, e0133325, 2015.

Arnold, J., Corre, M. D., and Veldkamp, E.: Cold storage and laboratory incubation of intact soil cores do not reflect in-situ nitrogen cycling rates of tropical forest soils, Soil Biol. Biochem., 40, 2480-2483, 2008.

Baldos, A. P., Corre, M. D., and Veldkamp, E.: Response of N cycling to nutrient inputs in forest soils across a 1000-3000m elevation gradient in the Ecuadorian Andes, Ecology, 96, 749-761, 2015.

Bodelier, P. L. E. and Laanbroek, H. J.: Nitrogen as a regulatory factor of methane oxidation in soils and sediments, FEMS Microbiol. Ecol., 47, 265-277, 2004.

BPS (Badan Pusat Statistik): Statistical office of Jambi Province, available at: http://jambi.bps.go.id/index.php?option=com_content\&view=article\&id=164:jambidalamangka-2011\&catid=5:publikasi-buku\&Itemid=30 (last access: 8 January 2014), 2012.

Carlson, K. M., Curran, L. M., Asner, G. P., Pittman, A. M., Trigg, S. N., and Adeney, J. M.: Carbon emissions from forest conversion by Kalimantan oil palm plantations, Nature Climate Change, 3, 283-287, 2013.

Clay, J.: World agriculture and the environment: a commodity-by-commodity guide to impacts and practices, Island Press, Washington, DC, USA, 2013.

Crawley, M. J.: The R Book, John Wiley \& Sons Ltd, Chichester, UK, 2007. 
Danielsen, F., Beukema, H., Burgess, N. D., Parish, F., Bruehl, C. A., Donald, P. F., Murdiyarso, D., Phalan, B., Reijnders, L., and Struebig, M.: Biofuel plantations on forested lands: double jeopardy for biodiversity and climate, Conserv. Biol., 23, 348-358, 2009.

Davidson, E. A., Verchot, L. V., Cattanio, J. H., Ackerman, I. L., and Carvalho, J. E. M.: Effects of soil water content on soil respiration in forests and cattle pastures of eastern Amazonia, Biogeochemistry, 48, 53-69, 2000.

Dechert, G., Veldkamp, E., and Anas, I.: Is soil degradation unrelated to deforestation?, Examining soil parameters of land use systems in upland Central Sulawesi, Indonesia, Plant Soil, 265, 197-209, 2004.

FAO, IIASA, ISRIC, ISS-CAS, and JRC: Harmonized World Soil Database (version 1.1), FAO, Rome, Italy \& IIASA, Laxenburg, Austria, 2009.

Food and Agricultural Organization: FAOSTAT database, available at: http://faostat.fao.org/site/339/default.aspx (last access: 5 November 2014), 2014.

Gouyon, A., de Foresta, H., and Levang, P.: Does “jungle rubber” deserve its name?, an analysis of rubber agroforestry systems in southeast Sumatra, Agroforest. Syst., 22, 181-206, 1993.

Hedin, L. O., Brookshire, E. N. J., Menge, D. N. L., and Barron, A. R.: The nitrogen paradox in tropical forest ecosystems, Annu. Rev. Ecol. Evol. S., 40, 613-635, 2009.

Indonesian Ministry of Agriculture: Statistical yearbook of crops for 2009-2013, Directorate General of Estate Crops, Jakarta, Indonesia, 2014.

IPCC: Climate Change 2007: The physical science basis, contribution of working group I to the fourth assessment report of the intergovernmental panel on climate change, Cambridge University Press, Cambridge, UK, New York, USA, 2007.

Ishizuka, S., Tsuruta, H., and Murdiyarso, D.: An intensive field study on $\mathrm{CO}_{2}, \mathrm{CH}_{4}$, and $\mathrm{N}_{2} \mathrm{O}$ emissions from soils at four land-use types in Sumatra, Indonesia, Global Biogeochem. Cy., 16, 22-1-22-11, 2002. 
Ishizuka, S., Iswandi, A., Nakajima, Y., Yonemura, S., Sudo, S., Tsuruta, H., and Murdiyarso, D.: The variation of greenhouse gas emissions from soils of various land-use/cover types in Jambi province, Indonesia, Nutr. Cycl. Agroecosys., 71, 17-32, 2005.

Keller, M. and Reiners, W. A.: Soil-atmosphere exchange of nitrous oxide, nitric oxide and methane under secondary succession of pasture to forest in the Atlantic lowlands of Costa Rica, Global Biogeochem. Cy., 8, 399-409, 1994.

Keller, M., Veldkamp, E., Weitz, A. M., and Reiners, W. A.: Effect of pasture age on soil trace gas emissions from a deforested area of Costa Rica, Nature, 365, 244-246, 1993.

Keller, M., Varner, R., Dias, J. D., Silva, H., Crill, P., and de Oliveira, R. C.: Soil-atmosphere exchange of nitrous oxide, nitric oxide, methane, and carbon dioxide in logged and undisturbed forest in the Tapajos National Forest, Brazil, Earth Interact., 9, 1-28, 2005.

Klinge, R., Martins, A. R. A., Mackensen, J., and Folster, H.: Element loss on rain forest conversion in East Amazonia: comparison of balances of stores and fluxes, Biogeochemistry, 69, 63-82, 2004.

Koehler, B., Corre, M. D., Veldkamp, E., and Sueta, J. P.: Chronic nitrogen addition causes a reduction in soil carbon dioxide efflux during the high stem-growth period in a tropical montane forest but no response from a tropical lowland forest on a decadal time scale, Biogeosciences, 6 , 2973-2983, 2009.

Koh, L. P. and Ghazoul, J.: Spatially explicit scenario analysis for reconciling agricultural expansion, forest protection, and carbon conservation in Indonesia, P. Natl. Acad. Sci. USA, 107, 11140-11144, 2010.

Kotowska, M. M., Leuschner, C., Triadiati, T., Meriem, S., and Hertel, D.: Quantifying above and belowground biomass carbon loss with forest conversion in tropical lowlands of Sumatra (Indonesia), Glob. Change Biol., 21, 3620-3634, 2015.

Laumonier, Y., Uryu, Y., Stüwe, M., Budiman, A., Setiabudi, B., and Hadian, O.: Eco-floristic sectors and deforestation threats in Sumatra: identifying new conservation area network priorities for ecosystem-based land use planning, Biodivers. Conserv., 19, 1153-1174, 2010. 
Ma, J. F., Ryan, P. R., and Delhaize, E.: Aluminium tolerance in plants and the complexing role of organic acids, Trends Plant Sci., 6, 273-278, 2001.

Margono, B. A., Turubanova, S., Zhuravleva, I., Potapov, P., Tyukavina, A., Baccini, A., Goetz, S., and Hansen, M. C.: Mapping and monitoring deforestation and forest degradation in Sumatra (Indonesia) using Landsat time series data sets from 1990 to 2010, Environ. Res. Lett., 7, 034010, 2012.

Melling, L., Hatano, R., and Goh, K. J.: Methane fluxes from three ecosystems in tropical peatland of Sarawak, Malaysia, Soil Biol. Biochem., 37, 1445-1453, 2005a.

Melling, L., Hatano, R., and Goh, K. J.: Soil $\mathrm{CO}_{2}$ flux from three ecosystems in tropical peatland of Sarawak, Malaysia, Tellus B, 57, 1-11, 2005b.

Ohashi, M., Kumagai, T. O., Kume, T., Gyokusen, K., Saitoh, T. M., and Suzuki, M.: Characteristics of soil $\mathrm{CO}_{2}$ efflux variability in an a seasonal tropical rainforest in Borneo Island, Biogeochemistry, 90, 275-289, 2008.

R Development Core Team: R: A language and environment for statistical computing, $\mathrm{R}$ Foundation for Statistical Computing, Vienna, Austria., 2015.

Raich, J. W. and Schlesinger, W. H.: The global carbon dioxide flux in soil respiration and its relationship to vegetation and climate, Tellus B, 44, 81-99, 1992.

Sahner, J., Budi, S. W., Barus, H., Edi, N., Meyer, M., Corre, M. D., and Polle, A.: Degradation of root community traits as indicator for transformation of tropical lowland rain forests into oil palm and rubber plantations, PLoS ONE, 10, e0138077, 2015.

Salimon, C., Davidson, E., Victoria, R., and Melo, A.: $\mathrm{CO}_{2}$ flux from soil in pastures and forests in southwestern Amazonia, Glob. Change Biol., 10, 833-843, 2004.

Schwendenmann, L., Veldkamp, E., Brenes, T., O’Brien, J. J., and Mackensen, J.: Spatial and temporal variation in soil $\mathrm{CO}_{2}$ efflux in an old-growth neotropical rain forest, La Selva, Costa Rica, Biogeochemistry, 64, 111-128, 2003. 
Seiler, W., Conrad, R., and Scharffe, D.: Field studies of methane emission from termite nests into the atmosphere and measurements of methane uptake by tropical soils, J. Atmos. Chem., 1, 171-186, 1984.

Sheng, H., Yang, Y., Yang, Z., Chen, G., Xie, J., Guo, J., and Zou, S.: The dynamic response of soil respiration to land-use changes in subtropical China, Glob. Change Biol., 16, 1107-1121, 2010.

Sotta, E. D., Veldkamp, E., Guimarães, B. R., Paixão, R. K., Ruivo, M. L. P., and Almeida, S. S.: Landscape and climatic controls on spatial and temporal variation in soil $\mathrm{CO}_{2}$ efflux in an Eastern Amazonian Rainforest, Caxiuanã, Brazil, Forest Ecol. Manag., 237, 57-64, 2006.

Sotta, E. D., Veldkamp, E., Schwendenmann, L., Guimarães, B. R., Paixão, R. K., Ruivo, M. D. L. P., Lola da Costa, A. C., and Meir, P.: Effects of an induced drought on soil carbon dioxide $\left(\mathrm{CO}_{2}\right)$ efflux and soil $\mathrm{CO}_{2}$ production in an Eastern Amazonian rainforest, Brazil, Glob. Change Biol., 13, 2218-2229, 2007.

Sotta, E. D., Corre, M. D., and Veldkamp, E.: Differing N status and N retention processes of soils under old-growth lowland forest in Eastern Amazonia, Caxiuanã, Brazil, Soil Biol. Biochem., 40, 740-750, 2008.

Tamai, N., Takenaka, C., Ishizuka, S., and Tezuka, T.: Methane flux and regulatory variables in soils of three equal-aged Japanese cypress (Chamaecyparis obtusa) forests in central Japan, Soil Biol. Biochem., 35, 633-641, 2003.

van Straaten, O., Veldkamp, E., and Corre, M. D.: Simulated drought reduces soil $\mathrm{CO}_{2}$ efflux and production in a tropical forest in Sulawesi, Indonesia, Ecosphere, 2, 119, 2011.

van Straaten, O., Corre, M. D., Wolf, K., Tchienkoua, M., Cuellar, E., Matthews, R. B., and Veldkamp, E.: Conversion of lowland tropical forests to tree cash crop plantations loses up to one-half of stored soil organic carbon, P. Natl. Acad. Sci. USA, 112, 9956-9960, 2015.

Veldkamp, E., Weitz, A. M., and Keller, M.: Management effects on methane fluxes in humid tropical pasture soils, Soil Biol. Biochem., 33, 1493-1499, 2001. 
Veldkamp, E., Purbopuspito, J., Corre, M. D., Brumme, R., and Murdiyarso, D.: Land use change effects on trace gas fluxes in the forest margins of Central Sulawesi, Indonesia, J. Geophys. Res.-Biogeo., 113, G02003, 2008.

Veldkamp, E., Koehler, B., and Corre, M. D.: Indications of nitrogen-limited methane uptake in tropical forest soils, Biogeosciences, 10, 5367-5379, 2013.

Verchot, L. V., Davidson, E. A., Cattanio, J. H., and Ackerman, I. L.: Land-use change and biogeochemical controls of methane fluxes in soils of eastern Amazonia, Ecosystems, 3, 41-56, 2000 .

Werner, C., Zheng, X., Tang, J., Xie, B., Liu, C., Kiese, R., and Butterbach-Bahl, K.: $\mathrm{N}_{2} \mathrm{O}, \mathrm{CH}_{4}$ and $\mathrm{CO}_{2}$ emissions from seasonal tropical rainforests and a rubber plantation in Southwest China, Plant Soil, 289, 335-353, 2006.

Wolf, K., Flessa, H., and Veldkamp, E.: Atmospheric methane uptake by tropical montane forest soils and the contribution of organic layers, Biogeochemistry, 111, 469-483, 2012. 


\title{
Chapter 3
}

\section{Soil nitrogen oxide fluxes from lowland forests converted to smallholder rubber and oil palm plantations in Sumatra, Indonesia}

\author{
Evelyn Hassler, Marife D. Corre, Syahrul Kurniawan, Edzo Veldkamp
}

Under review in Biogeosciences; doi: 10.5194/bg-2016-357

\begin{abstract}
Oil palm and rubber plantations cover large areas of former rainforest in Sumatra, Indonesia, supplying the global demand for these crops. Although forest conversion is known to influence soil nitrous oxide $\left(\mathrm{N}_{2} \mathrm{O}\right)$ and nitric oxide $(\mathrm{NO})$ fluxes, measurements from oil palm and rubber plantations are scarce (for $\mathrm{N}_{2} \mathrm{O}$ ) or nonexistent (for $\mathrm{NO}$ ). Our study aimed to (1) quantify changes in soil-atmosphere fluxes of N-oxides with forest conversion to rubber and oil palm plantations, and (2) determine their controlling factors. In Jambi, Sumatra, we selected two landscapes that mainly differed in texture but both on heavily weathered soils: loam and clay Acrisol soils. Within each landscape, we investigated lowland forest, rubber trees interspersed in secondary forest (termed as jungle rubber), both as reference land uses, and smallholder rubber and oil palm plantations, as converted land uses. Each land use had four replicate plots within each landscape. Soil $\mathrm{N}_{2} \mathrm{O}$ fluxes were measured monthly from December 2012 to December 2013, and soil NO fluxes were measured four times between March and September 2013. In the loam Acrisol landscape, we also conducted weekly to bi-weekly soil $\mathrm{N}_{2} \mathrm{O}$ flux measurements from July 2014 to July 2015 in a large-scale oil palm plantation with four replicate plots for comparison with smallholder oil palm plantations. Land-use conversion to smallholder plantations had no effect on soil $\mathrm{N}$-oxide fluxes ( $P=0.58$ to 0.76 ) due to the generally low soil $\mathrm{N}$ availability in the reference land uses that further decreased with land-use conversion. Over one-year measurements, the temporal patterns of soil $\mathrm{N}$-oxide fluxes were influenced by soil mineral $\mathrm{N}$ and water contents. Across landscapes, annual soil $\mathrm{N}_{2} \mathrm{O}$ emissions were controlled by gross nitrification and sand content, which also suggest the influence of soil $\mathrm{N}$ and water availability. Soil $\mathrm{N}_{2} \mathrm{O}$ fluxes ( $\mu \mathrm{g} \mathrm{N} \mathrm{m}^{-2} \mathrm{~h}^{-1}$ ) were: $7 \pm 2$ to $14 \pm 7$ (reference land uses), $6 \pm 3$ to $9 \pm 2$ (rubber), $12 \pm 3$ to $12 \pm 6$ (smallholder oil palm), and $42 \pm 24$ (large-scale oil palm). Soil NO fluxes ( $\mu \mathrm{g} \mathrm{N} \mathrm{m}^{-2} \mathrm{~h}^{-1}$ ) were: $-0.6 \pm 0.7$ to $5.7 \pm 5.8$ (reference land uses), $-1.2 \pm 0.5$ to -1.0
\end{abstract}


\pm 0.2 (rubber) and $-0.2 \pm 1.2$ to $0.7 \pm 0.7$ (smallholder oil palm). The low $\mathrm{N}$ fertilizer application in smallholder oil palm plantations (commonly 48 to $88 \mathrm{~kg} \mathrm{~N} \mathrm{ha}^{-1} \mathrm{yr}^{-1}$ ) resulted in N-oxide losses of only $0.2-0.7 \%$ of the applied N. To improve estimate of soil N-oxide fluxes from oil palm plantations in this region, studies should focus on large-scale plantations (which usually have two to four times higher $\mathrm{N}$ fertilization rates than smallholders) with frequent measurements following fertilizer application.

\subsection{Introduction}

Expansion of industrial forestry and agriculture has caused rapid deforestation in Sumatra, Indonesia, resulting in a total primary forest loss of $36 \%$ between 1990 and 2010 (Margono et al., 2012). Nowadays, most accessible lowland rainforests have been converted (Laumonier et al., 2010) into economically important crops, such as oil palm (Elaeis guineensis) and rubber (Hevea brasiliensis), with an area of 9.2 million hectare (Mha) (BPS, 2016a). Indonesia is currently the principal oil palm producer and second largest rubber producer worldwide (FAO, 2016), and Sumatra is the most important contributor to the Indonesian production (BPS, 2016b).

Despite the extent of land-use change in Sumatra, it is still uncertain how forest conversion will affect soil emissions of climate-relevant $\mathrm{N}$-oxide gases, nitrous oxide $\left(\mathrm{N}_{2} \mathrm{O}\right)$ and nitric oxide (NO). Only a few studies so far have reported soil $\mathrm{N}_{2} \mathrm{O}$ fluxes from forest conversion to these rapidly increasing and economically important land uses, oil palm and rubber, on lowland mineral soils in Southeast Asia (Aini et al., 2015; Ishizuka et al., 2002, 2005; Yashiro et al., 2008) and no study exists on soil NO fluxes.

Tropical forest soils are major sources of $\mathrm{N}_{2} \mathrm{O}$ and $\mathrm{NO}$, emitting $1.3 \mathrm{Tg} \mathrm{N}_{2} \mathrm{O}-\mathrm{N} \mathrm{yr}^{-1}$ (Werner et al., 2007) and 1.3 Tg NO-N yr ${ }^{-1}$ (Davidson and Kingerlee, 1997) to the atmosphere, whereby considerable amounts of NO are expected to get redirected in forest systems since NO is easily oxidized to $\mathrm{NO}_{2}$ which, in turn, is absorbed by leaves (Jacob and Bakwin, 1991; Sparks et al., 2001). $\mathrm{N}_{2} \mathrm{O}$ is a potent greenhouse gas (IPCC, 2013) and is projected to be the single most important ozone-depleting substance throughout the $21^{\text {st }}$ century (Ravishankara et al., 2009). NO plays an important role in the formation of tropospheric ozone, which in itself is an important greenhouse gas (Lammel and Graß1, 1995). $\mathrm{N}_{2} \mathrm{O}$ and $\mathrm{NO}$ are produced in soil by the microbial 
processes of nitrification and denitrification. The conceptual model of "hole-in-the-pipe" (HIP), which had been validated by studies in the tropics (Davidson et al., 2000), suggests that production and consumption of these gases in soils are influenced by two levels of control: first, the amount of soil available $\mathrm{N}$, and second, the soil water content. HIP suggests that the higher the soil $\mathrm{N}$ availability, the higher are the soil $\mathrm{N}$-oxide fluxes, and that well-aerated soil conditions (low moisture contents) favor for nitrification with $\mathrm{NO}$ as the main gaseous product while with increasing water content denitrification with increasing proportion of $\mathrm{N}_{2} \mathrm{O}$ prevails (Davidson et al., 2000). Although there are other factors affecting soil $\mathrm{N}_{2} \mathrm{O}$ and $\mathrm{NO}$ fluxes through their influence on nitrification and denitrification (e.g., soil $\mathrm{pH}$, temperature, bioavailable carbon; Firestone and Davidson, 1989; Heinen, 2006; Skiba and Smith, 2000), landscape-scale investigations in tropical areas show the dominant role of soil $\mathrm{N}$ availability and water content (Corre et al., 2014; Koehler et al., 2009; Müller et al., 2015).

Conversion of tropical forests to agricultural land uses generally alters soil $\mathrm{N}$-oxide fluxes through their effects on soil $\mathrm{N}$ availability and aeration as a consequence of management practices (e.g., fertilization, harvest, cultivation), which can add and export nutrients as well as compact or loosen the soil (Keller and Reiners, 1994; Veldkamp et al., 2008). In particular, the application of $\mathrm{N}$-containing fertilizers can increase $\mathrm{N}$-oxide emissions (Matson et al., 1996; Veldkamp et al., 1998) whereas agricultural land uses without fertilizer application lead to long-term reductions of soil N-oxide fluxes or to comparably low-level fluxes as those from previous forests (Ishizuka et al., 2005; Keller and Reiners, 1994; Verchot et al., 1999). In tropical regions, it has been shown that soil $\mathrm{NO}$ and $\mathrm{N}_{2} \mathrm{O}$ emissions can be very high following fertilizer application, constituting $6.4-8.6 \%$ of applied $\mathrm{N}$ fertilizer especially at high fertilizer application rates (Veldkamp and Keller, 1997; Veldkamp et al., 1998).

For lowland forests on highly weathered soils in Sumatra, Indonesia, where our present study was conducted, it has been shown that soil $\mathrm{N}$ availability (with gross rates of ammonium $\left(\mathrm{NH}_{4}{ }^{+}\right)$transformations as indices) is higher in the clay than loam Acrisol soils (Allen et al., 2015), suggesting that soil texture controls soil fertility which in turn affects plant productivity, soil water holding capacity, decomposition and ultimately soil-N cycling (Allen et al., 2015). Conversion of lowland forest and jungle rubber to oil palm and rubber on these Acrisol soils showed intermediate soil $\mathrm{N}$ availability in oil palm plantations, due to abatement of soil fertility 
decline by low to moderate applications of fertilizers and lime, whereas the unfertilized rubber plantations displayed the lowest soil $\mathrm{N}$ availability and fertility in general (Allen et al., 2015).

Our present study focuses on soil $\mathrm{N}_{2} \mathrm{O}$ and $\mathrm{NO}$ fluxes from a region in Jambi, Sumatra where increased deforestation for rubber and oil palm production has occurred in the last two decades. We covered four different land uses within two landscapes on highly weathered soils that mainly differed in soil texture (clay and loam Acrisols): forest, rubber trees interspersed in secondary forest (hereafter called jungle rubber) as the reference land uses, and smallholder rubber and oil palm plantations as the converted land uses. Based on the above mentioned findings on soil $\mathrm{N}$ availability, we hypothesized that (1) soil $\mathrm{N}_{2} \mathrm{O}$ and $\mathrm{NO}$ fluxes from the reference land uses will be higher in the clay than the loam Acrisol landscape, and that (2) forest and jungle rubber will have the highest soil $\mathrm{N}_{2} \mathrm{O}$ and $\mathrm{NO}$ fluxes, followed by the fertilized oil palm plantations (fertilized at low to moderate rates), and with the lowest fluxes from the unfertilized rubber plantations. Our study aimed to (1) quantify changes in soil-atmosphere fluxes of $\mathrm{N}$-oxides with forest conversion to smallholder oil palm and rubber plantations, (2) determine the temporal controls of soil N-oxide fluxes measured within one year, and (3) assess landscape-scale controlling factors of annual soil $\mathrm{N}_{2} \mathrm{O}$ fluxes from converted lowland landscapes in Sumatra, Indonesia. We also investigated the effect of fertilizer application intensity in oil palm plantations on soil $\mathrm{N}_{2} \mathrm{O}$ fluxes by comparing smallholder plantations with low to moderate $\mathrm{N}$ fertilizer input to a large-scale oil palm plantation with high $\mathrm{N}$ fertilizer input. Our study contributes to the much needed information on soil $\mathrm{N}$-oxide fluxes from these economically and globally relevant tropical land uses.

\subsection{Material and methods}

\section{Study area, experimental design and management practices}

The study region is situated in Jambi Province, Sumatra, Indonesia $\left(2^{\circ} 0,57^{\prime \prime} \mathrm{S}, 103^{\circ} 15^{\prime} 33^{\prime \prime} \mathrm{E}\right.$, and elevation of $73 \pm 3 \mathrm{~m}$ above sea level), where conversion of forest to rubber and oil palm plantations is widespread. The area has a mean annual temperature of $26.7 \pm 0.1{ }^{\circ} \mathrm{C}$ and a mean annual precipitation of $2235 \pm 385 \mathrm{~mm}$ (1991-2011; data from a climatological station at the Jambi Sultan Thaha Airport). During our study year (2013), annual rainfall in the study region 
was 3418-3475 mm (data from climatological stations at the Harapan Forest Reserve, Sarolangun and Lubuk Kepayang, approximately 10-20 km from our sites), which were higher than the long term average. Total dissolved $\mathrm{N}$ deposition via rainfall was between $12.9 \pm 0.1$ and $16.4 \pm 2.6 \mathrm{~kg} \mathrm{~N} \mathrm{ha}^{-1} \mathrm{yr}^{-1}$, measured at two locations in the study region during 2013 (Kurniawan, 2016).

We delineated the study region in two landscapes, which have the same highly weathered soil group but mainly differed in soil texture: clay and loam Acrisol soils. The clay Acrisol soil had larger $\mathrm{pH}(4.5 \pm 0.0)$, base saturation $(23 \pm 6 \%)$ and Bray-extractable $\mathrm{P}\left(1.4 \pm 0.1 \mathrm{~g} \mathrm{P} \mathrm{m}^{-2}\right)$ and lower Al saturation $(61 \pm 3 \%)$ in the top $10 \mathrm{~cm}$ depth compared to the loam Acrisol soil $\left(4.3 \pm 0.0 \mathrm{pH}, 11 \pm 1 \%\right.$ base saturation, $0.5 \pm 0.1 \mathrm{~g} \mathrm{P} \mathrm{m}^{-2}$ and $80 \pm 1 \%$ Al saturation) (all $P \leq 0.05$; Allen et al., 2015). Within each landscape, we investigated four land-use types: lowland forest, jungle rubber, both as the reference land uses, and smallholder monoculture plantations of rubber and oil palm, as the converted land uses. Each land use within each landscape had four sites as replicates, and we laid out a $50 \mathrm{~m} \times 50 \mathrm{~m}$ plot in each replicate site; in total we had 32 plots. Within each plot, a $10 \times 10$ grid was established and we randomly selected four subplots $(5 \mathrm{~m} \times 5 \mathrm{~m}$ each) per plot, each with one permanently installed chamber base for measurements of soil N-oxide fluxes. All measurements (see next section) were conducted in 2013. A more detailed description of the study sites and plot design was reported earlier by Allen et al. (2015) and Hassler et al. (2015).

In the loam Acrisol landscape, we conducted additional measurements in a large-scale oil palm plantation (called PTPN VI) from 2014 to 2015 in order to compare with the smallholder oil palm plantations within the same landscape. In the PTPN VI site, we selected four replicates at a distance of $50 \mathrm{~m}$ apart. At each replicate, we installed three permanent chamber bases at $0.8 \mathrm{~m}, 2.8 \mathrm{~m}$ and $4.8 \mathrm{~m}$ from the tree base, in order to characterize possible spatial variation caused by management practices within each replicate.

Based on our interviews with the smallholders, the monoculture plantations were established after clearing and burning of either forest or jungle rubber and hence these land uses served as the reference land uses with which the converted plantations were compared. Additionally, the comparability of initial soil conditions between the reference and converted land uses was tested based on a land use-independent soil characteristic, i.e., clay content at 0.5- 
$2 \mathrm{~m}$ depth, which did not statistically differ among land uses within each landscape (Allen et al., 2015; Hassler et al., 2015). Thus, changes in soil N-oxide fluxes can be attributed to land-use change with its associated management practices. The plantations' ages ranged between 7 and 17 years, and tree density, tree height, basal area and tree species abundance were higher in the reference land uses than the monoculture plantations (all reported by Allen et al., 2015; Hassler et al., 2015; Kotowska et al., 2015).

Management practices in the plantations included manual harvest, weeding and fertilizer application. Harvesting of palm fruits was done every 2 weeks and collection of latex was done weekly. In the large-scale oil palm plantation PTPN VI, palm fruits were harvested weekly. Weeding in smallholder rubber and oil palm plantations was done both manually and with herbicides $\left(2-5\right.$ L Gramaxone ${ }^{\circledR}$ or Roundup ${ }^{\circledR} \mathrm{ha}^{-1} \mathrm{yr}^{-1}$ ) one to two times per year, and senesced oil palm fronds were regularly cut and piled on the inter-rows (Hassler et al., 2015). In PTPN VI, weeding was done with herbicides (1-1.5 L Glisat $\left.{ }^{\circ} \mathrm{ha}^{-1} \mathrm{yr}^{-1}\right)$ four times per year, combined with some manual hoeing, and senesced fronds were cut and partly piled on the inter-rows and partly taken out from the plot to use as fodder for cattle. Fertilizer application in the smallholder oil palm plantations was done one to two times per year and rates typically varied depending on cash capital of the smallholders. In 2013, fertilization rates ranged between $48-88 \mathrm{~kg} \mathrm{~N}^{-1} \mathrm{yr}^{-1}$ (except two smallholders who applied $138 \mathrm{~kg} \mathrm{~N} \mathrm{ha}^{-1} \mathrm{yr}^{-1}$ ), 21-38 $\mathrm{kg} \mathrm{P} \mathrm{ha}^{-1} \mathrm{yr}^{-1}$ and 40-157 $\mathrm{kg} \mathrm{K}$ $\mathrm{ha}^{-1} \mathrm{yr}^{-1}$, with the lower range in the clay Acrisol and the upper range in the loam Acrisol. The fertilizer sources were NPK complete, urea and $\mathrm{KCl}$. One of the smallholders in the loam Acrisol landscape applied $200 \mathrm{~kg}$ dolomite $\mathrm{ha}^{-1} \mathrm{yr}^{-1}$. Fertilizers were applied around each palm tree at about 0.8-1 $\mathrm{m}$ from the stem base (Hassler et al., 2015). Rubber plantations were not fertilized. In the large-scale oil palm plantation PTPN VI, fertilizer application rates were typically higher than those in smallholder plantations; fertilizers were applied once in 2014 at the rates of

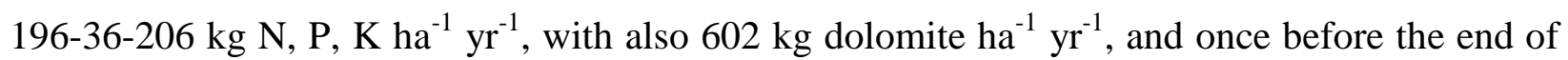
our measurements in July 2015 at the rates of 96-23-96 kg N, P, K ha ${ }^{-1} \mathrm{yr}^{-1}$. The fertilizer forms were NPK complete, urea, triple superphosphate and $\mathrm{KCl}$. Application was done partly manually by applying the fertilizers at $1 \mathrm{~m}$ distance around each palm tree, and partly mechanically by broadcasting the fertilizer within 1-3 m distance from the palm rows. In 2015, fertilizers were mainly mechanically broadcasted within these inter-rows. 


\section{Soil N-oxide fluxes and supporting soil factors}

In 32 plots, soil $\mathrm{N}_{2} \mathrm{O}$ fluxes were measured monthly from December 2012 to December 2013, whereas soil NO fluxes were measured four times between March and September 2013, except in two forest sites and one jungle rubber site in the clay Acrisol landscape, where we were unable to measure soil NO fluxes due to difficulty in accessing these sites that did not allow us to stabilize the NO detector during transport in the field (i.e., using motorcycle on very rugged trails). Soil $\mathrm{NO}$ fluxes were not measured as frequently as $\mathrm{N}_{2} \mathrm{O}$ fluxes and we decided to stop in September 2013 because NO fluxes were always very low at all sites. In the large-scale oil palm plantation PTPN VI within the loam Acrisol landscape, soil $\mathrm{N}_{2} \mathrm{O}$ fluxes were measured more frequently (in congruent with its high fertilizer application rate): weekly to biweekly from July 2014 to July 2015, with the exception of September 2014 when we measured only once.

With our sampling strategy, where we used randomly installed chamber bases (with the distances to the tree base between 1.8 and $5 \mathrm{~m}$ ) in combination with monthly measurements, we may have missed the $\mathrm{N}$ fertilizer-induced pulse of soil $\mathrm{N}$-oxide emissions in the smallholder oil palm plantations. Therefore, we conducted more intensive measurements of soil $\mathrm{N}_{2} \mathrm{O}$ fluxes during 3 to 8.5 weeks (with 6 to 11 samplings) following fertilizer application at three of the smallholder oil palm plantations within each landscape. These measurements served to characterize the short-term, $\mathrm{N}$ fertilizer-induced contribution (e.g., Koehler et al., 2009) to total $\mathrm{N}_{2} \mathrm{O}$ fluxes. Soil $\mathrm{NO}$ fluxes were also measured during 6 to 8.5 weeks (with 9 to 10 samplings) following fertilizer application at one of the smallholder oil palm plantations within each landscape. In the clay Acrisol landscape, measurements in the three smallholder oil palm plantations were conducted during October-December 2013, February-March 2014, and February-April 2014; in the loam Acrisol, measurements were carried out during OctoberDecember 2013, January-March 2014, and March-April 2014. We applied the same fertilizer forms, rates and methods as used by the smallholders. Three oil palm trees were selected in each of the six sites. In the clay Acrisol landscape, each tree was applied with $2 \mathrm{~kg}$ complete NPK fertilizer (equivalent to $0.32 \mathrm{~kg} \mathrm{~N}$ tree $^{-1}$ ), whereas in the loam Acrisol, each tree was applied with $2 \mathrm{~kg}$ of combined complete NPK, ammonium sulfate and $\mathrm{KCl}$ fertilizers (equivalent to $0.26 \mathrm{~kg} \mathrm{~N}$

tree $\left.^{-1}\right)$. The fertilizer was applied within $0.8-1 \mathrm{~m}$ distance from the tree base. We installed three permanent chamber bases at various distances from the tree base: $0.3 \mathrm{~m}$ from the tree base 
(chamber location a), $0.8 \mathrm{~m}$ from the tree base that was on the fertilized area (chamber location b), and 4-4.5 $\mathrm{m}$ from the tree base that was in the middle of the inter-rows and served as the reference chamber without fertilizer application (chamber location c).

Soil $\mathrm{N}_{2} \mathrm{O}$ fluxes were measured using the same methods employed in our earlier studies (e.g., Corre et al., 2014; Koehler et al., 2009). During gas sampling, the permanently installed chamber bases were covered with static vented, polyethylene hoods (chamber area of $0.05 \mathrm{~m}^{2}$ and total volume of $12 \mathrm{~L}$ ), and four gas samples (30 mL each) were taken at 1, 11, 21 and $31 \mathrm{~min}$ after chamber closure by connecting a syringe with a Luer-lock connection to the chamber sampling port. Gas samples were immediately injected into pre-evacuated $12 \mathrm{~mL}$ Labco Exetainers sealed with rubber septa (Labco Limited, Lampeter, UK), maintaining an overpressure; these exetainers have been tested by our group to be leak proof during extended period of storage (e.g., up to 6 months) (Hassler et al., 2015). Within 3-4 months the gas samples were transported by airfreight to Germany and were analyzed upon arrival using a gas chromatograph with an electron capture detector (GC 6000 Vega Series 2, Carlo Erba Instruments, Milan, Italy). For the measurements from March-July 2015 in the large-scale oil palm plantation PTPN VI, the gas samples were analyzed with another gas chromatograph (SRI 8610C, SRI Instruments Europe GmbH, Bad Honnef, Germany), which had been previously cross-calibrated using the same standards. For calibration, three standard gases were used with concentrations of 360, 1000 and $1600 \mathrm{ppb} \mathrm{N}_{2} \mathrm{O}$ (Deuste Steininger GmbH, Mühlhausen, Germany).

Soil NO fluxes were measured (described in detail in our earlier works, e.g., Corre et al., 2014; Koehler et al., 2009) using the same chamber bases described above. During measurements, the chamber bases were covered with dynamic vented, polyethylene hoods (total volume of $12 \mathrm{~L}$ ), and NO concentrations were measured in situ during 5-7 min following chamber closure using a Scintrex LMA-3 chemiluminescence detector (Scintrex, Ontario, Canada), in which $\mathrm{NO}$ is oxidized to $\mathrm{NO}_{2}$ by a $\mathrm{CrO}_{3}$ catalyst after which it reacts with a luminol solution. Calibration of the NO detector was carried out at each site prior to and after measurements using a two-point calibration of a standard gas with $3000 \mathrm{ppb}$ NO (Deuste Steininger GmbH, Mühlhausen, Germany) which was diluted using dried ambient air. NO 
measurements were recorded every 5 seconds using a data logger (CR510, Campbell Scientific, Logan, USA).

Soil $\mathrm{N}_{2} \mathrm{O}$ and $\mathrm{NO}$ fluxes were calculated from the linear increase of concentration over time adjusted for air temperature and atmospheric pressure, measured at each site and sampling day. Annual soil $\mathrm{N}_{2} \mathrm{O}$ fluxes from the weekly or monthly sampling at each site were estimated using the trapezoidal rule on day intervals between measured flux rates, assuming constant flux rates per day (e.g., Hassler et al., 2015). Annual NO fluxes were not calculated, since we only conducted four measurement periods for each plot as explained above. To calculate the $\mathrm{N}$ fertilizer-induced pulse of soil N-oxide fluxes, we also used the trapezoidal rule on day intervals between measured flux rates to estimate the total flux during the entire period following fertilizer application, covering pre-fertilizer level, the peak, and the return to background levels of soil $\mathrm{N}$-oxide fluxes. We calculated the percentage of combined soil $\mathrm{NO}$ and $\mathrm{N}_{2} \mathrm{O}$ emissions from the applied $\mathrm{N}$-fertilizer rate at each site as follows: \% NO-N $+\mathrm{N}_{2} \mathrm{O}-\mathrm{N}$ of $\mathrm{N}$ applied $\mathrm{yr}^{-1}=\mathrm{NO}-\mathrm{N}+$ $\mathrm{N}_{2} \mathrm{O}-\mathrm{N}$ fluxes from the fertilized chamber locations a and $\mathrm{b}\left(\mu \mathrm{g} \mathrm{N} \mathrm{m} \mathrm{N}^{-2}\right.$ for the entire period of

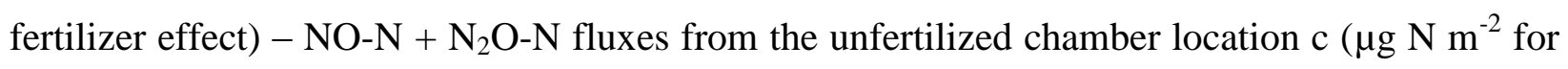
the same period) $*$ frequency of fertilization $\mathrm{yr}^{-1} *$ fertilized area $\left(\mathrm{m}^{2} \mathrm{ha}^{-1}\right) \div \mathrm{N}$ fertilization rate $\left(\mathrm{kg} \mathrm{N} \mathrm{ha}^{-1} \mathrm{yr}^{-1} * 10^{9} \mu \mathrm{g} / \mathrm{kg}\right) * 100$. In this calculation, we included fluxes from chamber location a in order to include any incidental fertilizer application to this area (possibly from previous applications by the smallholders and possible redistribution of applied nutrients within the soil) since $\mathrm{N}$-oxide fluxes from chamber location a were often higher than those from unfertilized chamber location c (see Sect. 3.3).

Soil factors known to control soil N-oxide fluxes (i.e., temperature, water-filled pore space (WFPS), and extractable $\mathrm{NH}_{4}{ }^{+}$and nitrate $\left(\mathrm{NO}_{3}{ }^{-}\right)$were measured for the top $0.05 \mathrm{~m}$ depth during each soil N-oxide flux measurement at all 32 sites. Soil temperature was measured close to each chamber base using a digital thermometer. Soil samples were taken at $1 \mathrm{~m}$ distance from the four chambers, pooled, mixed thoroughly, and subsampled for immediate extraction of mineral $\mathrm{N}$ in the field, using prepared extraction bottles containing $150 \mathrm{~mL} 0.5 \mathrm{M} \mathrm{K}_{2} \mathrm{SO}_{4}$. Upon arrival at the field station, extraction bottles were shaken for $1 \mathrm{~h}$, filtered and extracts were frozen immediately. The remaining soil sample was used to determine the gravimetric moisture content (by oven-drying for at least 1 day at $105{ }^{\circ} \mathrm{C}$ ), whereby WFPS was calculated using a 
particle density of $2.65 \mathrm{~g} \mathrm{~cm}^{-3}$ for mineral soil and the measured soil bulk density at our study sites (Allen et al., 2015). During the measurements following the fertilizer applications, soil was sampled close to each of the chamber locations a, b and c (described above) and was processed separately for mineral $\mathrm{N}$ extraction and WFPS determination. Frozen extracts were transported by airfreight to Germany and analyzed for $\mathrm{NH}_{4}{ }^{+}$and $\mathrm{NO}_{3}{ }^{-}$concentrations using continuous flow injection colorimetry (SEAL Analytical AA3, SEAL Analytical GmbH, Norderstedt, Germany), as described in detail by Hassler et al. (2015).

\section{Statistical analysis}

We first tested each parameter for normal distribution (Shapiro-Wilk's test) and equality of variance (Levene's test), and a logarithmic transformation was applied when necessary. For analysis of differences in N-oxide fluxes among land uses or between soil landscapes, we used the means of the four chambers representing each replicate plot on a sampling day. Linear mixed-effect (LME) models (Crawley, 2007) were used to assess differences between landscapes for the reference land uses (i.e., clay vs. loam Acrisol; first hypothesis) or differences among land uses within each landscape (i.e., land-use change effect; second hypothesis). In the LME models, either landscape or land use was considered as fixed effect whereas replicate plots and sampling days were considered as random effects. For comparison of soil $\mathrm{N}_{2} \mathrm{O}$ fluxes between the large-scale (PTPN VI) and smallholder oil palm plantations in the loam Acrisol landscape, we also used the means of the three chambers per replicate in the PTPN VI site on each sampling day as there were no significant differences between the chamber locations (based on LME models with chamber location as fixed effect and replicates as well as sampling days as random effects; $P=0.70$ ). We then used the LME model with plantation types (i.e., large scale vs. smallholder) as a fixed effect and replicates and sampling days as random effects. For analysis of fertilization effects (i.e., as represented by the chamber locations a, b and c) on soil N-oxide fluxes from smallholder oil palm plantations, this was conducted for each site with oil palm trees as replicates. In the LME model for this experiment, chamber location was the fixed effect whereas replicate palm trees and sampling days were the random effects. To assess differences in $\mathrm{N}$-oxide fluxes between landscapes following fertilization for chamber locations a and $\mathrm{b}$, we also used LME models with landscape as fixed effect and with replicate plots (for $\mathrm{N}_{2} \mathrm{O}$ ) or replicate 
palm trees (for NO) and sampling days as random effects. In all LME models, we included (1) a variance function that allows different variances of the fixed effect, and/or (2) a first-order temporal autoregressive function to account for decreasing correlation between sampling days with increasing time difference, if these functions improved the relative goodness of the model fit based on the Akaike information criterion. Significant differences were based on the analysis of variance with Fisher's least significant difference test for multiple comparisons. We set the statistical significance at $P \leq 0.05$ and, only for a few specified parameters, we also considered marginal significance at $P \leq 0.09$ because our experimental design encompassed the inherently high spatial variability in our study area (e.g., Hassler et al., 2015).

To assess the temporal relationships between soil N-oxide fluxes and soil factors (temperature, WFPS, $\mathrm{NO}_{3}{ }^{-}$and $\mathrm{NH}_{4}{ }^{+}$), we used the means of the replicate plots per land use on each of the 12 monthly measurements and conducted Pearson's correlation test separately for the reference land uses (forest and jungle rubber, $n=48\left(\mathrm{~N}_{2} \mathrm{O}\right), n=16(\mathrm{NO})$ ) and the converted land uses (rubber and oil palm, $n=48,\left(\mathrm{~N}_{2} \mathrm{O}\right), n=16(\mathrm{NO})$ ) across landscapes for the whole year. Similarly, for soil $\mathrm{N}_{2} \mathrm{O}$ and NO fluxes following fertilizer application from smallholder oil palm plantations, we used the means of the three replicate trees per chamber location on each sampling day and conducted Pearson's correlation test for each site across the entire measurement period of fertilization effects $(n=6-11)$. To assess the spatial controls of soil biochemical characteristics (Appendix Table A3.1) on annual soil $\mathrm{N}_{2} \mathrm{O}$ fluxes, we used the annual flux of each replicate plot and conducted Spearman's rank correlation test separately for the reference land uses and converted land uses across landscapes $(n=16)$ and within each landscape $(n=8)$. We did not assess the spatial control of soil biochemical characteristics on annual soil NO fluxes since we did not calculate annual flux from the four measurement periods (as explained in the previous section). Correlations were considered statistically significant at $P \leq 0.05$ and marginally significant at $P \leq 0.09$. All statistical analyses were conducted using $\mathrm{R} 3.2 .2$ (R Development Core Team, 2015). 


\subsection{Results}

\section{Soil N-oxide fluxes}

In the reference land uses, $\mathrm{N}_{2} \mathrm{O}$ was the dominant $\mathrm{N}$-oxide emitted from soils; in the clay Acrisol landscape there was a net $\mathrm{NO}$ consumption in the soil of the jungle rubber (Table 3.1). Soil $\mathrm{N}_{2} \mathrm{O}$ and NO fluxes from reference land uses were comparable between the two landscapes $(P=0.54$ 0.74; Table 3.1; Fig. 3.1a, b). These fluxes also exemplified high inherent spatial and temporal variations as indicated by their large standard errors.

Table 3.1. Mean ( $\pm \mathrm{SE}, n=4$ sites) soil $\mathrm{N}_{2} \mathrm{O}$ and $\mathrm{NO}$ fluxes and annual soil $\mathrm{N}_{2} \mathrm{O}$ fluxes from different land uses within each landscape in Jambi, Sumatra, Indonesia, measured monthly from December 2012 to December 2013. Means followed by different lowercase letters indicate significant differences among land uses within each landscape and different capital letters indicate significant differences between landscapes within each land use (linear mixed-effect models with Fisher's LSD test at $P \leq 0.09$ ). For soil NO fluxes in the clay Acrisol, forest was excluded in the comparison among land uses because its monthly measurements was only carried out in two sites due to road inaccessibility with the NOmeasuring instrument in the other two sites. Annual soil $\mathrm{N}_{2} \mathrm{O}$ fluxes were not statistically tested for differences between landscapes or land uses since these annual values are trapezoidal extrapolations. For smallholder oil palm plantations, values in italics are the fertilizer-induced annual soil $\mathrm{N}_{2} \mathrm{O}$ fluxes (see Sect. 3.2). In the loam Acrisol landscape, soil $\mathrm{N}_{2} \mathrm{O}$ fluxes were additionally measured in a large-scale oil palm plantation (mean \pm SE, $n=4$ replicates) from July 2014 to July 2015; these fluxes did not differ from those of smallholder plantations in the same landscape (linear mixed-effect models with Fisher's LSD test at $P=0.15$ ) due to large spatial variation (indicated by large $\mathrm{SE}$ ).

\begin{tabular}{llll}
\hline Land-use type & $\begin{array}{l}\mathrm{N}_{2} \mathrm{O} \text { fluxes } \\
\left(\mu \mathrm{g} \mathrm{m}^{-2} \mathrm{~h}^{-1}\right)\end{array}$ & $\begin{array}{l}\text { NO fluxes } \\
\left(\mu \mathrm{g} \mathrm{N} \mathrm{m}^{-2} \mathrm{~h}^{-1}\right)\end{array}$ & $\begin{array}{l}\text { Annual N} \mathrm{O} \text { fluxes } \\
\left(\mathrm{kg} \mathrm{N} \mathrm{ha}^{-1} \text { year }^{-1}\right)\end{array}$ \\
\hline clay Acrisol landscape & & & \\
\hline Forest & $12.76 \pm 5.57^{\mathrm{a}, \mathrm{A}}$ & $(1.70 \pm 0.32)$ & $1.03 \pm 0.41$ \\
Jungle rubber & $6.73 \pm 1.50^{\mathrm{a}, \mathrm{A}}$ & $-0.56 \pm 0.69^{\mathrm{a}, \mathrm{A}}$ & $0.62 \pm 0.14$ \\
Rubber & $5.56 \pm 2.47^{\mathrm{a}, \mathrm{A}}$ & $-1.00 \pm 0.15^{\mathrm{a}, \mathrm{A}}$ & $0.46 \pm 0.21$ \\
$\begin{array}{l}\text { Oil palm } \\
\text { (smallholder plantation) }\end{array}$ & $11.47 \pm 2.88^{\mathrm{a}, \mathrm{A}}$ & $-0.20 \pm 1.23^{\mathrm{a}, \mathrm{A}}$ & $1.01 \pm 0.25$ \\
\hline loam Acrisol landscape & & & $0.21 \pm 0.04$ \\
\hline Forest & $9.77 \pm 1.46^{\mathrm{a}, \mathrm{A}}$ & $1.87 \pm 1.27^{\mathrm{ab}}$ & $0.88 \pm 0.15$ \\
Jungle rubber & $14.01 \pm 6.69^{\mathrm{a}, \mathrm{A}}$ & $5.68 \pm 5.77^{\mathrm{a}, \mathrm{A}}$ & $1.19 \pm 0.57$ \\
Rubber & $8.61 \pm 2.04^{\mathrm{a}, \mathrm{A}}$ & $-1.16 \pm 0.49^{\mathrm{b}, \mathrm{A}}$ & $0.69 \pm 0.17$ \\
Oil palm (smallholder plantation) & $12.16 \pm 6.08^{\mathrm{a}, \mathrm{A}}$ & $0.73 \pm 0.67^{\mathrm{ab}, \mathrm{A}}$ & $1.13 \pm 0.53$ \\
& & & $0.07 \pm 0.02$ \\
Oil palm (large-scale plantation) & $42.34 \pm 24.22^{\mathrm{a}, \mathrm{A}}$ & - & $3.26 \pm 1.73$ \\
\hline
\end{tabular}



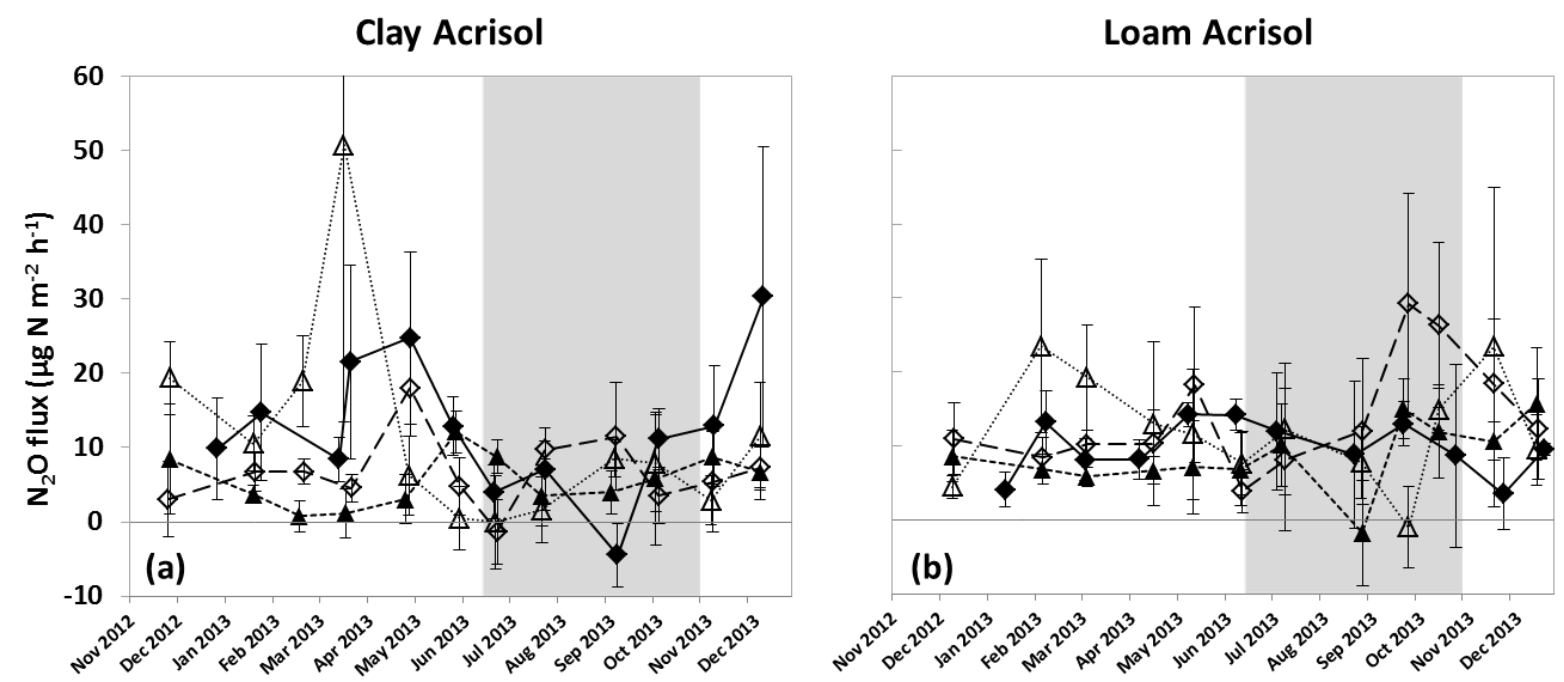

Figure 3.1. Mean $\left( \pm \mathrm{SE}, n=4\right.$ sites) soil $\mathrm{N}_{2} \mathrm{O}$ fluxes from forest $(\bullet)$, jungle rubber $(\diamond)$, rubber $(\boldsymbol{\Delta})$ and oil palm $(\Delta)$, located within the clay (a) and loam Acrisol (b) landscapes in Jambi, Sumatra, Indonesia. Measurements were carried out monthly from December 2012 to December 2013; grey shadings mark the dry season.

In the converted land uses, soil $\mathrm{N}_{2} \mathrm{O}$ fluxes were similar to the fluxes of reference land uses $(P=0.58-0.76$; Table 3.1; Fig. 3.1a, b) within each landscape. However, in the loam Acrisol landscape, the large-scale oil palm plantation PTPN VI had on average 3.5 times higher soil $\mathrm{N}_{2} \mathrm{O}$ fluxes than those from the smallholder plantations (Table 3.1), although this trend was not statistically different $(P=0.15)$ because of the large variation among replicate plots (as indicated by the large standard error) in this large-scale plantation. Soil NO fluxes, were not different either among land uses in the clay Acrisol landscape $(P=0.73$; Table 3.1). However, in the loam Acrisol landscape, soil NO fluxes were marginally lower $(P=0.07)$ in rubber plantations (with net NO consumption in the soil) than in jungle rubber (with net NO emission), whereas they were intermediary in forests and oil palm plantations (Table 3.1). 


\section{Fertilization effects on soil $\mathbf{N}$-oxide fluxes from smallholder oil palm plantations}

In comparison to the unfertilized area (chamber location $\mathrm{c}$ at $4-4.5 \mathrm{~m}$ from the tree base) soil $\mathrm{N}_{2} \mathrm{O}$ fluxes were on average 442 times (clay Acrisol) and 22 times (loam Acrisol) higher within the small fertilized areas around the oil palms (chamber location $\mathrm{b}$ at $0.8-1 \mathrm{~m}$ from the tree base) during the 3 to 8.5 weeks following fertilizer applications (all $P<0.01-0.03$; Table 3.2; Fig. $3.2 \mathrm{c}, \mathrm{d})$. In chamber location a, soil $\mathrm{N}_{2} \mathrm{O}$ emissions were also 25 times higher compared to the reference chamber location $\mathrm{c}$ in the clay Acrisol landscape (all $P<0.01$; Table 3.2; Fig. 3.2a).

Table 3.2. Mean ( $\pm \mathrm{SE}, n=3$ oil palm trees) soil $\mathrm{N}_{2} \mathrm{O}$ and $\mathrm{NO}$ fluxes from three chamber locations during a fertilization in three (for $\mathrm{N}_{2} \mathrm{O}$ ) or one (for $\mathrm{NO}$ ) smallholder oil palm plantation within each landscape, measured 6 to 11 times during 3-8.5 weeks following fertilization. Means followed by different letters indicate significant differences among chamber locations within each site (linear mixed-effect models with Fisher's LSD test at $P \leq 0.05$ ). Chamber locations a, b and c were placed at 0.3 $\mathrm{m}, 0.8 \mathrm{~m}$, and 4-4.5 m, respectively, from each of the three trees in each oil palm plantation site. Smallholders fertilized around the base of each tree at about $0.8-1 \mathrm{~m}$ from the tree base, and thus chamber location $\mathrm{b}$ was on this fertilized area and chamber location $\mathrm{c}$ served as the reference chamber not receiving any fertilizer. The same fertilization rate and form were used as the smallholders applied in these plantations (see Sect. 3.2).

\begin{tabular}{|c|c|c|c|}
\hline Oil palm site & Chamber location & $\begin{array}{l}\mathrm{N}_{2} \mathrm{O} \text { fluxes } \\
\left(\mu \mathrm{g} \mathrm{N} \mathrm{m}^{-2} \mathrm{~h}^{-1}\right)\end{array}$ & $\begin{array}{l}\text { NO fluxes } \\
\left(\mu \mathrm{g} \mathrm{N} \mathrm{m}^{-2} \mathrm{~h}^{-1}\right)\end{array}$ \\
\hline \multicolumn{4}{|c|}{ clay Acrisol landscape } \\
\hline \multirow[t]{3}{*}{1} & $\mathrm{a}$ & $156.66 \pm 86.76^{b}$ & - \\
\hline & $\mathrm{b}$ & $910.11 \pm 410.00^{\mathrm{a}}$ & - \\
\hline & $\mathrm{c}$ & $6.93 \pm 3.30^{c}$ & - \\
\hline \multirow[t]{3}{*}{2} & $\mathrm{a}$ & $130.62 \pm 34.62^{b}$ & - \\
\hline & $\mathrm{b}$ & $692.74 \pm 144.10^{\mathrm{a}}$ & - \\
\hline & $\mathrm{c}$ & $9.87 \pm 3.01^{\mathrm{c}}$ & - \\
\hline \multirow[t]{3}{*}{3} & a & $45.49 \pm 3.73^{\mathrm{b}}$ & $4.74 \pm 1.74^{\mathrm{b}}$ \\
\hline & $\mathrm{b}$ & $1280.95 \pm 486.67^{\mathrm{a}}$ & $535.29 \pm 194.46^{\mathrm{a}}$ \\
\hline & $\mathrm{c}$ & $1.14 \pm 1.64^{\mathrm{c}}$ & $1.50 \pm 1.46^{\mathrm{b}}$ \\
\hline \multicolumn{4}{|c|}{ loam Acrisol landscape } \\
\hline \multirow[t]{3}{*}{1} & $\mathrm{a}$ & $33.46 \pm 9.76^{b}$ & - \\
\hline & $\mathrm{b}$ & $133.36 \pm 34.90^{\mathrm{a}}$ & - \\
\hline & $\mathrm{c}$ & $11.82 \pm 6.08^{\mathrm{b}}$ & - \\
\hline \multirow[t]{3}{*}{2} & $\mathrm{a}$ & $129.74 \pm 46.19^{\mathrm{a}}$ & $46.17 \pm 19.63^{b}$ \\
\hline & $\mathrm{b}$ & $205.31 \pm 24.17^{\mathrm{a}}$ & $157.12 \pm 35.67^{\mathrm{a}}$ \\
\hline & $\mathrm{c}$ & $7.89 \pm 4.78^{\mathrm{b}}$ & $0.66 \pm 0.30^{\mathrm{b}}$ \\
\hline \multirow[t]{3}{*}{3} & a & $5.17 \pm 1.04^{\mathrm{b}}$ & - \\
\hline & $\mathrm{b}$ & $104.53 \pm 81.90^{\mathrm{a}}$ & - \\
\hline & $\mathrm{c}$ & $3.68 \pm 1.74^{\mathrm{b}}$ & - \\
\hline
\end{tabular}



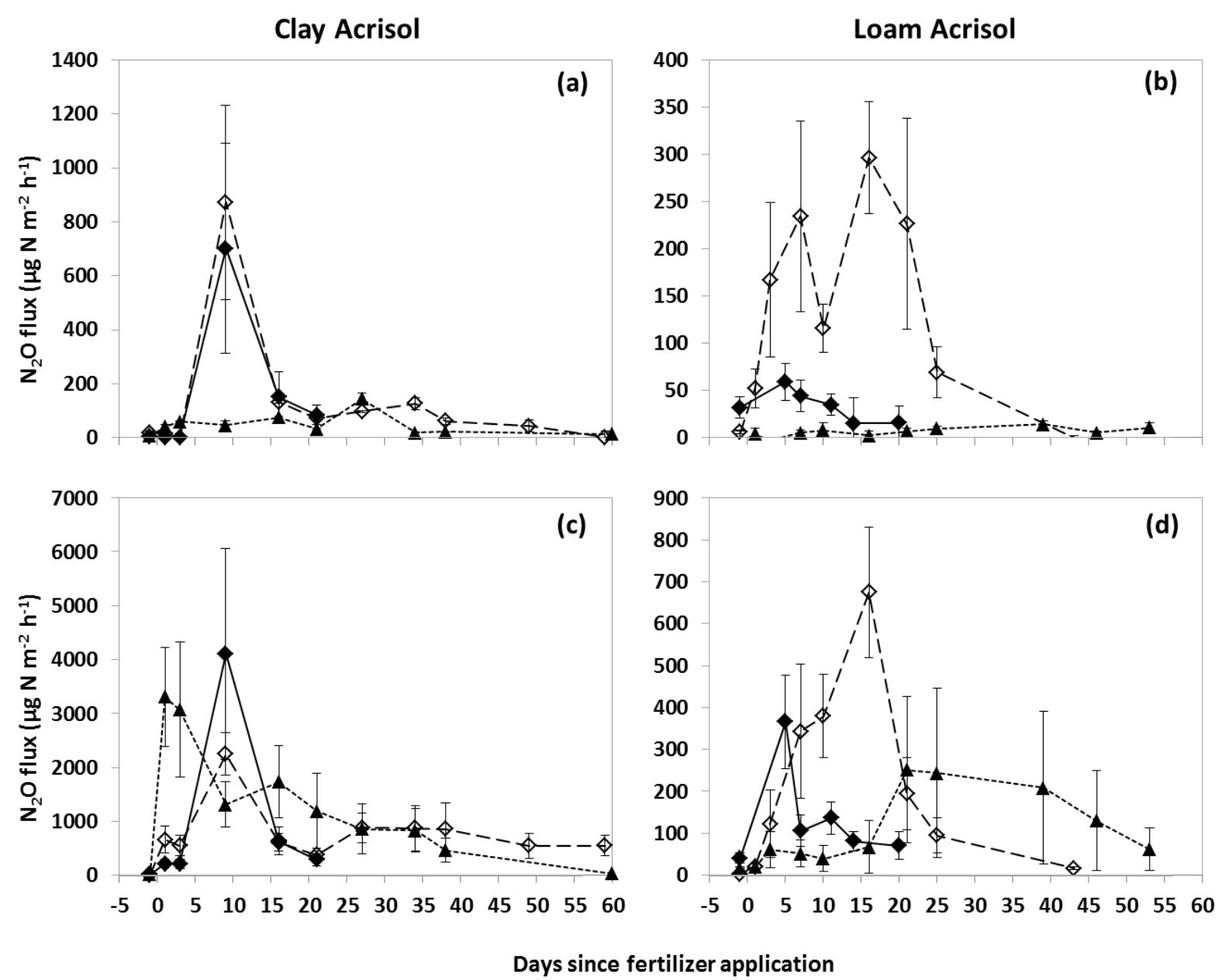

Figure 3.2. Mean $\left( \pm \mathrm{SE}, n=3\right.$ oil palm trees) soil $\mathrm{N}_{2} \mathrm{O}$ fluxes during a fertilization in smallholder oil palm plantations $1(\bullet), 2(\diamond)$ and $3(\mathbf{\Delta})$ in the clay (a and c) and loam Acrisol (b and d) landscapes. Smallholders fertilized around the base of each tree at about $0.8-1 \mathrm{~m}$ from the tree base. Fluxes were measured at $0.3 \mathrm{~m}$ from the tree base (a and $\mathbf{b})$ and at $0.8 \mathrm{~m}$ on the fertilized location (c and $\mathbf{d})$ with the same rate and form that smallholders used (see Sect. 3.2).

In the loam Acrisol landscape, we only detected such an effect in site 2 which displayed 16 times higher soil $\mathrm{N}_{2} \mathrm{O}$ emissions in chamber location a compared to the reference chamber location $\mathrm{c}$ $(P=0.03$; Table 3.2; Fig. 3.2b).

In the clay Acrisol landscape, soil $\mathrm{N}_{2} \mathrm{O}$ emissions in chamber location $\mathrm{b}$ increased immediately after fertilizer application, reached a peak within 9 days following fertilizer application and stayed elevated for at most 2 months (Fig. 3.2c). In the loam Acrisol landscape, $\mathrm{N}_{2} \mathrm{O}$ fluxes in chamber location $\mathrm{b}$ increased within the first 5 days, reached maximum fluxes 
within 5-21 days and remained elevated for at most 6.5 weeks (Fig. 3.2d). Soil $\mathrm{N}_{2} \mathrm{O}$ fluxes in chamber location a displayed a similar but less pronounced pattern as those of chamber location b in both landscapes (Fig. 3.2a, b).

Considering the area coverage ( $4 \%$ of the area in a hectare) and time span of fertilizerinduced $\mathrm{N}_{2} \mathrm{O}$ emissions, their average contributions were $21 \%$ to the annual fluxes in the clay Acrisol landscape (with its usual fertilizer application of once a year), and only $6 \%$ to the annual fluxes in the loam Acrisol landscape (with its common fertilizer application of twice a year) (Table 3.1).

Compared to the unfertilized area (chamber location c), soil NO fluxes from the fertilized area (chamber location b) had on average 357 times (clay Acrisol) and 238 times (loam Acrisol) higher fluxes (both $P<0.01$ ) during 6 to 8.5 weeks of measurements following fertilizer application (Table 3.2; Fig. 3.3c, d). No differences in soil NO fluxes were detected between chamber locations a and c $(P=0.10-0.12$; Table 3.2; Fig. 3.3a, b). Soil NO fluxes in chamber location b peaked after 10 days in the loam Acrisol and after 3 weeks in the clay Acrisol landscape (Fig. 3.3c, d), and returned to the background fluxes after 6-8.5 weeks with a drastic drop after 3-5 weeks (Fig. 3.3c, d). In chamber location a, soil NO fluxes increased quickly and decreased to the background fluxes within at most 16 days following fertilizer application (Fig. 3.3a, b). As was the case for the monthly sampling, soil $\mathrm{N}_{2} \mathrm{O}$ fluxes from chamber locations $\mathrm{a}$ and $\mathrm{b}$ were larger than soil NO fluxes for both landscapes, (Table 3.2; Fig. 3.2a-d and 3.3a-d). Comparing between landscapes, soil $\mathrm{N}_{2} \mathrm{O}$ fluxes from chamber location $\mathrm{b}$ were higher in the clay than loam Acrisol soils ( $P=0.09$; Table 3.2; Fig. 3.2c, d) but were comparable for chamber location a $(P=0.41$; Table 3.2 ; Fig. 3.2a, b) and for soil NO fluxes of both chamber locations $(P=0.45-0.78$; Table 3.2; Fig. 3.3a-d).

Fertilizer-induced soil NO fluxes in the loam Acrisol landscape were $0.07 \pm 0.02$ $\mathrm{kg}$ NO-N ha ${ }^{-1} \mathrm{yr}^{-1}$, which was roughly the same as our extrapolated annual value of $0.06 \pm 0.06$ $\mathrm{kg} \mathrm{NO}-\mathrm{N} \mathrm{ha}^{-1} \mathrm{yr}^{-1}$ from the four measurement periods (Table 3.1). In the clay Acrisol landscape, fertilizer-induced soil NO fluxes were $0.12 \pm 0.04 \mathrm{~kg} \mathrm{NO}-\mathrm{N} \mathrm{ha}{ }^{-1} \mathrm{yr}^{-1}$, which was a net emission compared to our extrapolated annual value with a net sink of $-0.02 \pm 0.11 \mathrm{~kg}$ NO-N ha ${ }^{-1} \mathrm{yr}^{-1}$, based on the four measurement periods (Table 3.1). The percentages of combined soil $\mathrm{N}_{2} \mathrm{O}$ and 
NO fluxes to the applied $\mathrm{N}$ fertilizer rate were on average $0.73 \% \mathrm{yr}^{-1}$ in the clay Acrisol landscape and $0.20 \% \mathrm{yr}^{-1}$ in the loam Acrisol landscape.
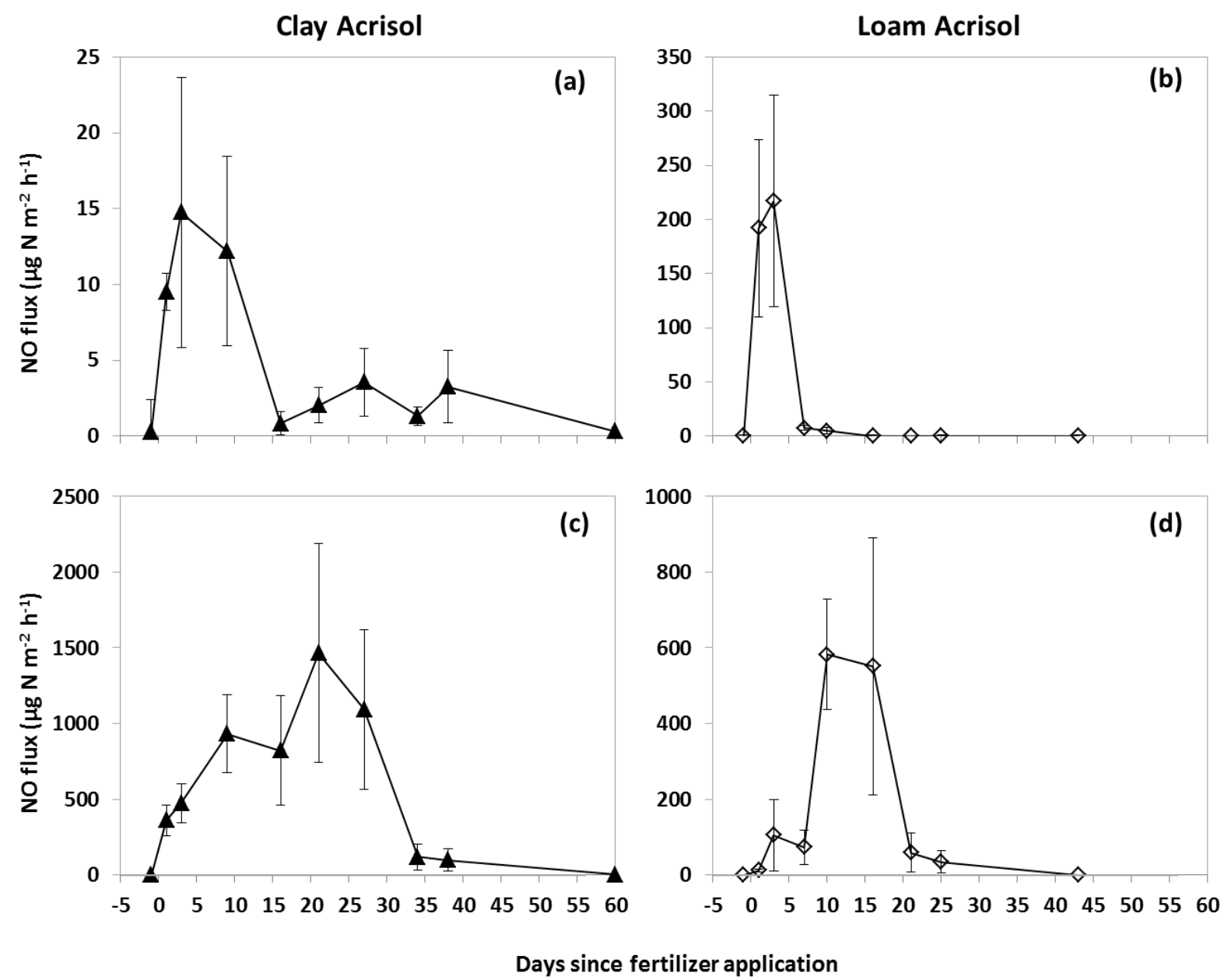

Figure 3.3. Mean ( \pm SE, $n=3$ oil palm trees) soil NO fluxes during a fertilization in a smallholder oil palm plantation in the clay (a and c) and loam Acrisol (b and d) landscapes. Smallholders fertilized around the base of each tree at about $0.8-1 \mathrm{~m}$ from the tree base. Fluxes were measured at $0.3 \mathrm{~m}$ from the tree base (a and $\mathbf{b}$ ) and at $0.8 \mathrm{~m}$ on the fertilized location (c and $\mathbf{d}$ ) with the same rate and form that smallholders used (see Sect. 3.2). 


\section{Temporal controls of soil $N$-oxide fluxes}

In the reference land uses, soil $\mathrm{N}_{2} \mathrm{O}$ and $\mathrm{NO}$ fluxes were both positively correlated with soil $\mathrm{NO}_{3}{ }^{-}$ contents, while soil NO fluxes were also negatively correlated with WFPS and soil $\mathrm{NH}_{4}{ }^{+}$ contents (Table 3.3). In the converted land uses, soil $\mathrm{N}_{2} \mathrm{O}$ fluxes were positively correlated with soil $\mathrm{NO}_{3}{ }^{-}$contents and temperature (Table 3.3). This latter correlation was influenced by one sampling period with high $\mathrm{N}_{2} \mathrm{O}$ (fertilizer-induced) emissions; when this period was excluded in the analysis, we did not detect a significant correlation with soil temperature. There were no significant correlations observed between soil NO fluxes and soil factors in the converted land uses due to the very low NO emissions and even net NO uptake.

Table 3.3. Pearson correlation coefficients between soil $\mathrm{N}_{2} \mathrm{O}$ flux $\left(n=48 ; \mu \mathrm{g} \mathrm{m}^{-2} \mathrm{~h}^{-1}\right)$, soil NO flux $(n=$ $16 ; \mu \mathrm{g} \mathrm{N} \mathrm{m} \mathrm{h}^{-1}$ ), water-filled pore space (WFPS; \%, top $0.05 \mathrm{~m}$ depth), soil temperature $\left({ }^{\circ} \mathrm{C}\right.$, top $0.05 \mathrm{~m}$ depth) and extractable mineral $\mathrm{N}$ (mg N kg converted land uses. Correlation was conducted using the means of the four replicate plots per land use on each monthly measurement from December 2012 to December 2013 (soil $\mathrm{N}_{2} \mathrm{O}$ fluxes) and March 2013 to September 2013 (soil NO fluxes).

\begin{tabular}{llllll}
\hline Land-use type & Variable & WFPS & $\begin{array}{l}\text { Soil } \\
\text { temp. }\end{array}$ & $\mathrm{NH}_{4}{ }^{+}$ & $\mathrm{NO}_{3}{ }^{-}$ \\
\hline $\begin{array}{l}\text { Reference land uses } \\
\text { (forest and jungle rubber) }\end{array}$ & Soil $\mathrm{N}_{2} \mathrm{O}$ flux & -0.21 & -0.09 & -0.23 & $0.38^{\mathrm{c}}$ \\
& Soil NO flux & $-0.74^{\mathrm{c}}$ & -0.15 & $-0.48^{\mathrm{a}}$ & $0.69^{\mathrm{c}}$ \\
$\begin{array}{l}\text { Converted land uses } \\
\text { (rubber and oil palm) }\end{array}$ & Soil $\mathrm{N}_{2} \mathrm{O}$ flux & 0.11 & $0.30^{\mathrm{b}}$ & 0.23 & $0.37^{\mathrm{c}}$ \\
& Soil NO flux & -0.05 & 0.09 & -0.05 & 0.23 \\
\hline${ }^{\mathrm{a}} P \leq 0.09,{ }^{\mathrm{b}} P \leq 0.05,{ }^{\mathrm{c}} P \leq 0.01$. & & & & &
\end{tabular}

From the fertilizer application experiment in the smallholder oil palm plantations, the location directly receiving fertilizer (chamber location b) showed positive correlations of soil $\mathrm{N}_{2} \mathrm{O}$ fluxes with soil $\mathrm{NH}_{4}{ }^{+}$and/or $\mathrm{NO}_{3}{ }^{-}$contents in three of the six sites (Table 3.4). Here, also soil $\mathrm{NO}$ fluxes correlated positively with soil $\mathrm{NO}_{3}{ }^{-}$contents in the loam Acrisol but not in the clay Acrisol (Table 3.4). In chamber location a, positive correlations of soil $\mathrm{N}_{2} \mathrm{O}$ fluxes with soil $\mathrm{NH}_{4}{ }^{+}$and/or $\mathrm{NO}_{3}{ }^{-}$contents were observed in four of the six sites (Table 3.4). The correlations of soil $\mathrm{N}_{2} \mathrm{O}$ fluxes with mineral $\mathrm{N}$ for chamber location a in site 2 of the clay Acrisol landscape were caused by one measurement period with very high flux, and exclusion of this observation 
Table 3.4. Pearson correlation coefficients $(n=6-11$ measurements following fertilization) between N-oxide fluxes ( $\mu \mathrm{g} \mathrm{N} \mathrm{m}^{-2} \mathrm{~h}^{-1}$ ), water-filled pore space (WFPS; \%, top $0.05 \mathrm{~m}$ depth) and extractable mineral $\mathrm{N}$ ( $\mathrm{mg} \mathrm{N} \mathrm{kg}^{-1}$, top $0.05 \mathrm{~m}$ depth), measured at different chamber locations (a, b and c were at 0.3 $\mathrm{m}, 0.8 \mathrm{~m}$ (fertilized area) and 4-4.5 m, respectively, from each of the three trees in each smallholder oil palm plantation). Correlation was conducted using the means of the three replicate trees per chamber location.

\begin{tabular}{|c|c|c|c|c|c|}
\hline $\begin{array}{l}\text { Oil palm plantation } \\
\text { site }\end{array}$ & Chamber location & Variable & WFPS & $\mathrm{NH}_{4}^{+}$ & $\mathrm{NO}_{3}^{-}$ \\
\hline \multicolumn{6}{|c|}{ clay Acrisol landscape } \\
\hline \multirow{3}{*}{$\begin{array}{l}1 \\
(n=6 \\
\text { measurements })\end{array}$} & $\mathrm{a}$ & \multirow[t]{3}{*}{ Soil $\mathrm{N}_{2} \mathrm{O}$ flux } & 0.55 & $0.88^{b}$ & 0.46 \\
\hline & $b$ & & 0.57 & -0.22 & -0.31 \\
\hline & $\mathrm{c}$ & & 0.37 & -0.64 & -0.44 \\
\hline \multirow{3}{*}{$\begin{array}{l}2 \\
(n=11 \\
\text { measurements })\end{array}$} & a & \multirow[t]{3}{*}{ Soil $\mathrm{N}_{2} \mathrm{O}$ flux } & 0.11 & $0.93^{c}$ & $0.95^{\mathrm{c}}$ \\
\hline & $\mathrm{b}$ & & 0.08 & 0.05 & -0.06 \\
\hline & $\mathrm{c}$ & & 0.09 & -0.44 & -0.45 \\
\hline \multirow{3}{*}{$\begin{array}{l}3 \\
(n=10 \\
\text { measurements })\end{array}$} & $\mathrm{a}$ & \multirow[t]{3}{*}{ Soil $\mathrm{N}_{2} \mathrm{O}$ flux } & -0.19 & 0.1 & 0.09 \\
\hline & $\mathrm{b}$ & & 0.05 & $0.86^{\mathrm{c}}$ & $0.85^{\mathrm{c}}$ \\
\hline & c & & -0.32 & 0.06 & -0.44 \\
\hline \multirow{3}{*}{$\begin{array}{l}3 \\
(n=10 \\
\text { measurements })\end{array}$} & $\mathrm{a}$ & \multirow[t]{3}{*}{ Soil NO flux } & -0.34 & 0.44 & 0.48 \\
\hline & $b$ & & $-0.61^{\mathrm{a}}$ & 0.10 & -0.04 \\
\hline & $\mathrm{c}$ & & $0.59^{\mathrm{a}}$ & -0.14 & -0.13 \\
\hline \multicolumn{6}{|c|}{ loam Acrisol landscape } \\
\hline \multirow{3}{*}{$\begin{array}{l}1 \\
(n=6 \\
\text { measurements })\end{array}$} & $\mathrm{a}$ & \multirow[t]{3}{*}{ Soil $\mathrm{N}_{2} \mathrm{O}$ flux } & $0.96^{c}$ & -0.18 & 0.03 \\
\hline & $\mathrm{b}$ & & $0.78^{\mathrm{a}}$ & 0.61 & -0.40 \\
\hline & $\mathrm{c}$ & & -0.06 & -0.29 & $<0.01$ \\
\hline \multirow{3}{*}{$\begin{array}{l}2 \\
(n=9 \\
\text { measurements) }\end{array}$} & a & \multirow[t]{3}{*}{ Soil $\mathrm{N}_{2} \mathrm{O}$ flux } & -0.55 & $0.71^{b}$ & -0.03 \\
\hline & $b$ & & 0.35 & -0.20 & $0.89^{c}$ \\
\hline & $\mathrm{c}$ & & 0.34 & $<0.01$ & -0.35 \\
\hline \multirow{3}{*}{$\begin{array}{l}3 \\
(n=11 \\
\text { measurements })\end{array}$} & a & \multirow[t]{3}{*}{ Soil $\mathrm{N}_{2} \mathrm{O}$ flux } & $-0.68^{b}$ & $0.67^{b}$ & $0.62^{b}$ \\
\hline & $b$ & & -0.27 & -0.20 & $0.57^{\mathrm{a}}$ \\
\hline & $\mathrm{c}$ & & 0.36 & 0.19 & 0.06 \\
\hline \multirow{3}{*}{$\begin{array}{l}2 \\
(n=9 \\
\text { measurements })\end{array}$} & $\mathrm{a}$ & \multirow[t]{3}{*}{ Soil NO flux } & -0.07 & 0.18 & -0.27 \\
\hline & $\mathrm{b}$ & & 0.07 & -0.11 & $0.96^{\mathrm{c}}$ \\
\hline & $\mathrm{c}$ & & -0.16 & 0.12 & -0.23 \\
\hline
\end{tabular}

${ }^{\mathrm{a}} P \leq 0.09,{ }^{\mathrm{b}} P \leq 0.05,{ }^{\mathrm{c}} P \leq 0.01$. 
resulted in a none significant correlation. For soil NO fluxes from chamber location a, we did not detect any significant correlation with soil factors (Table 3.4). A positive correlation of soil $\mathrm{N}_{2} \mathrm{O}$ fluxes with WFPS was observed for chamber locations $a$ and $b$ in site 1 of the loam Acrisol landscape, whereas this correlation was negative for chamber location a in site 3 of the same landscape (Table 3.4). We also detected a negative correlation between soil NO fluxes and WFPS for chamber location $b$ in site 3 of the clay Acrisol, whereas in the same site soil NO fluxes and WFPS were positively correlated for the unfertilized chamber location c (Table 3.4); however this latter correlation was caused by only one sampling time with a high flux and high WFPS.

\section{Spatial controls of annual soil $\mathrm{N}_{2} \mathrm{O}$ fluxes}

The soil physical and biochemical characteristics used for this correlation analysis are reported in Table A3.1. For the reference land uses, annual $\mathrm{N}_{2} \mathrm{O}$ fluxes were positively correlated with gross nitrification rates across landscapes (Spearman's $\rho=0.57, P=0.02, n=16$ ). Within each landscape, annual soil $\mathrm{N}_{2} \mathrm{O}$ fluxes correlated negatively with soil $\mathrm{C}: \mathrm{N}$ ratio $(\rho=-0.69, P=0.07$, $n=8)$ in the clay Acrisol, whereas in the loam Acrisol annual soil $\mathrm{N}_{2} \mathrm{O}$ fluxes correlated positively with microbial $\mathrm{C}(\rho=0.69, P=0.07, n=8)$. For the converted land uses, annual $\mathrm{N}_{2} \mathrm{O}$ fluxes correlated negatively with sand content across landscapes $(\rho=-0.57, P=0.06, n=12)$. There were no other correlations detected with any other soil biochemical parameters.

\subsection{Discussion}

\section{Soil $\mathrm{N}_{2} \mathrm{O}$ and $\mathrm{NO}$ fluxes from the reference land uses}

$\mathrm{N}_{2} \mathrm{O}$ fluxes from our forest soils (Table 3.1) fell at the lower end of those reported for humid tropical forests $\left(9.8-85.1 \mu \mathrm{g} \mathrm{N}_{2} \mathrm{O}-\mathrm{N} \mathrm{m}^{-2} \mathrm{~h}^{-1}\right.$; summarized by Castaldi et al., 2013). Compared to soil $\mathrm{N}_{2} \mathrm{O}$ fluxes measured in Indonesia, our values were comparable to those from montane forests on Cambisol soil (at $1190 \mathrm{~m}$ elevation in Sulawesi) with similar temporal sampling scheme and spatial replication $\left(12.7 \mu \mathrm{g} \mathrm{N}_{2} \mathrm{O}-\mathrm{N} \mathrm{m}^{-2} \mathrm{~h}^{-1}\right.$; Purbopuspito et al., 2006) and to five lowland forest stands on Acrisol soil (at 0-180 m elevation in Jambi) measured once (11.6 $\mu \mathrm{g}$ 
$\mathrm{N}_{2} \mathrm{O}-\mathrm{N} \mathrm{m}^{-2} \mathrm{~h}^{-1}$; Ishizuka et al., 2005). However, soil $\mathrm{N}_{2} \mathrm{O}$ fluxes from our forests were lower than those reported from submontane and montane forests on Cambisol soil (at 450-1160 m elevation in Sulawesi) with six monthly measurements and comparable spatial replication $\left(25 \mu \mathrm{g} \mathrm{N} \mathrm{N}_{2} \mathrm{O}-\mathrm{N}\right.$ $\mathrm{m}^{-2} \mathrm{~h}^{-1}$; Veldkamp et al., 2008) and from a lowland forest on Ferralsol soil (at $100 \mathrm{~m}$ elevation in Jambi) with 13 monthly measurements $\left(19.8 \mu \mathrm{g} \mathrm{N} \mathrm{N}_{2} \mathrm{O}-\mathrm{N} \mathrm{m}^{-2} \mathrm{~h}^{-1}\right.$; Aini et al., 2015). In contrast, our values were higher than those reported for two lowland forests on Ferralsol soil (at approximately $100 \mathrm{~m}$ elevation in Jambi) with nine monthly measurements $\left(3.0 \mu \mathrm{g} \mathrm{N}_{2} \mathrm{O}-\mathrm{N} \mathrm{m}^{-2}\right.$ $\mathrm{h}^{-1}$; Ishizuka et al., 2002). Since the studies from the montane forests were conducted on less weathered soils and the studies from the same region by Ishizuka et al. (2002, 2005) and Aini et al. (2015) have less temporal or spatial replication, their values should be carefully related to our measured fluxes.

Soil NO fluxes from Southeast Asian lowland forests are not reported so far. Our measured NO fluxes from the forest soils (Table 3.1) tended to be lower than those reported for lowland forests in Latin America with soils ranging from less weathered Cambisols to highly weathered Acrisols and Ferralsols (3.2 $\mu \mathrm{g}$ NO-N m${ }^{-2} \mathrm{~h}^{-1}$, Corre et al., 2014; $10.3 \mathrm{NO}-\mathrm{N} \mathrm{m}^{-2} \mathrm{~h}^{-1}$, Davidson et al., 2004; 88.0-90.0 $\mu \mathrm{g}$ NO-N m${ }^{-2} \mathrm{~h}^{-1}$, Keller et al., 2005; $17.4 \mu \mathrm{g}$ NO-N m${ }^{-2} \mathrm{~h}^{-1}$, Verchot et al., 1999). There are only two studies that reported soil NO fluxes from montane forests on Cambisol soils in Sulawesi, Indonesia (Purbopuspito et al., 2006, Veldkamp et al., 2008). Our measured soil NO fluxes were comparable with the values reported for montane forests at $\geq 1800 \mathrm{~m}$ elevation (1.9-2.1 $\mu \mathrm{g}$ NO-N m${ }^{-2} \mathrm{~h}^{-1}$; Purbopuspito et al., 2006) but lower than those reported for (pre)montane forests at lower elevations $\left(5.5 \mu \mathrm{g} \mathrm{NO}-\mathrm{N} \mathrm{m}^{-2} \mathrm{~h}^{-1}\right.$ at $1190 \mathrm{~m}$, Purbopuspito et al., 2006; $12.0 \mu \mathrm{g}$ NO-N m${ }^{-2} \mathrm{~h}^{-1}$ at 450-1160 m, Veldkamp et al., 2008). Although it is known that tropical forest soils are the largest natural source of $\mathrm{N}_{2} \mathrm{O}$ and produce considerable amounts of NO, our measurements from these lowland forests in Jambi, Indonesia on highly weathered Acrisol soils showed generally low soil N-oxide fluxes.

In contrast to our first hypothesis, soil $\mathrm{N}$-oxide fluxes from the reference land uses were comparable between loam and clay Acrisol landscapes. This is possibly due to the generally low soil $\mathrm{N}$ availability in these sites, as indicated by their lower gross $\mathrm{N}$ mineralization rates (Allen et al., 2015) compared, for example, to the less weathered Cambisol and Nitisol soils in a lowland forest of Panama (Corre et al., 2010). Soil N-oxide fluxes are largely controlled, first, by the 
magnitude of soil $\mathrm{N}$ availability, as depicted in the HIP conceptual model (Davidson et al., 2000). This influence of soil $\mathrm{N}$ availability on $\mathrm{N}$-oxide fluxes was illustrated by the positive correlations of soil $\mathrm{N}$-oxide fluxes with soil $\mathrm{NO}_{3}{ }^{-}$contents (Table 3.3). Across landscapes, this first level of control was also corroborated by the positive correlations of annual soil $\mathrm{N}_{2} \mathrm{O}$ fluxes with gross nitrification rates, and within each landscape by the negative correlation with the soil $\mathrm{C}: \mathrm{N}$ ratio (clay Acrisol landscape) and by the positive correlation with microbial C (loam Acrisol landscape) (see Sect. 3.3). Our findings were consistent with those from other tropical soils, illustrating that soil $\mathrm{N}$-oxide fluxes across or within sites are controlled by soil $\mathrm{N}$ availability as expressed in various indexes such as soil $\mathrm{NO}_{3}{ }^{-}$contents (Keller and Reiners, 1994; Müller et al., 2015), nitrification rates (Davidson et al., 2000) and soil C:N ratio (Breuer et al., 2000).

Moreover, we attributed the low soil NO fluxes and the dominance of $\mathrm{N}_{2} \mathrm{O}$ (Table 3.1) in our sites to the second level of control of N-oxide fluxes - soil aeration status (HIP model; Davidson et al., 2000). The ratio of $\mathrm{N}_{2} \mathrm{O}$ to $\mathrm{NO}$ is expected to increase when WFPS exceeds $60 \%$ as low soil aeration favors $\mathrm{N}_{2} \mathrm{O}$ production by denitrification and nitrification processes (Davidson et al., 2000). WFPS in the reference land uses were $\geq 60 \%$ (Appendix Table A3.2, except in jungle rubber of the loam Acrisol with $54 \%$ WFPS). Hence, it was not surprising that our measured soil NO fluxes were close to zero or showed net consumption (Table 3.1); the high WFPS may have led to $\mathrm{NO}$ reduction to $\mathrm{N}_{2} \mathrm{O}$ (Conrad, 1996; Pilegaard, 2013). This was supported by the negative correlation between soil NO fluxes and WFPS (Table 3.3). Furthermore, increased concentrations of NO in the atmosphere due to biomass burning in this region (Field et al., 2009; Levine, 1999) may have resulted in a net NO consumption (not only in the reference land uses but also in the converted land uses; Table 3.1) since increased ambient NO concentration could enhanced soil NO uptake (Conrad, 1994). In summary, soil NO fluxes from the reference land uses were of minor importance compared to soil $\mathrm{N}_{2} \mathrm{O}$ fluxes. However, if droughts will occur more frequently or extremely in this region (Lestari et al., 2014), soil NO fluxes might become important. 


\section{Land-use change effects on soil $\mathrm{N}_{2} \mathrm{O}$ and $\mathrm{NO}$ fluxes}

Soil $\mathrm{N}_{2} \mathrm{O}$ fluxes from our rubber plantations (Table 3.1) were comparable to fluxes from a rubber plantation on Ferralsol soil (at approximately $110 \mathrm{~m}$ elevation in Peninsular Malaysia) with eight measurements during 1.5-year period (7.8 $\mu \mathrm{g} \mathrm{N}_{2} \mathrm{O}-\mathrm{N} \mathrm{m}^{-2} \mathrm{~h}^{-1}$; Yashiro et al., 2008) and slightly higher than fluxes reported from a rubber plantation on a lateritic soil (at $580 \mathrm{~m}$ elevation in Xishuangbanna, China) with only two months of sampling $\left(4.1 \mu \mathrm{g} \mathrm{N}_{2} \mathrm{O}-\mathrm{N} \mathrm{m}^{-2} \mathrm{~h}^{-1}\right.$; Werner et al., 2006). Studies from the same region (Jambi, Indonesia) report lower soil $\mathrm{N}_{2} \mathrm{O}$ fluxes from one rubber plantation on Ferralsol soil (at approximately $100 \mathrm{~m}$ elevation) with nine monthly measurements $\left(0.7 \mu \mathrm{g} \mathrm{N} \mathrm{N}_{2} \mathrm{O}-\mathrm{N} \mathrm{m}^{-2} \mathrm{~h}^{-1}\right.$; Ishizuka et al., 2002) as well as higher fluxes from five rubber plantations on Acrisol soils (at 70-280 m elevation) with only one-time measurement (20.6 $\mu \mathrm{g} \mathrm{N} \mathrm{N}_{2} \mathrm{O}-\mathrm{N} \mathrm{m}^{-2} \mathrm{~h}^{-1}$; Ishizuka et al., 2005) and from one rubber plantation on Ferralsol soil (at $100 \mathrm{~m}$ elevation) with 13 monthly measurements (11.6 $\mu \mathrm{g} \mathrm{N} \mathrm{N}_{2} \mathrm{O}-\mathrm{N} \mathrm{m}^{-2} \mathrm{~h}^{-1}$; Aini et al., 2015). Soil $\mathrm{N}_{2} \mathrm{O}$ fluxes from our oil palm sites were in the same order of magnitude as those reported from three oil palm plantations on Acrisol soils (at 70-110 m elevation) with only one-time sampling (15.1 $\mu \mathrm{g} \mathrm{N} \mathrm{N}_{2} \mathrm{O}-\mathrm{N} \mathrm{m}^{-2} \mathrm{~h}^{-1}$; Ishizuka et al., 2005) and from one oil palm plantation on Cambisol soil (at $70 \mathrm{~m}$ elevation) with 13 monthly measurements $\left(11.9 \mu \mathrm{g} \mathrm{N} \mathrm{N}_{2} \mathrm{O}-\mathrm{N} \mathrm{m}^{-2} \mathrm{~h}^{-1}\right.$; Aini et al., 2015), whereby both studies were also conducted in Jambi, Indonesia. However, soil $\mathrm{N}_{2} \mathrm{O}$ fluxes from our oil palm sites were higher compared to fluxes reported from one oil palm plantation on Ferralsol soil (at approximately $110 \mathrm{~m}$ elevation) in Peninsular Malaysia with eight measurements during 1.5-year period (-0.1 $\mu \mathrm{g} \mathrm{N}_{2} \mathrm{O}-\mathrm{N} \mathrm{m}^{-2} \mathrm{~h}^{-1}$; Yashiro et al., 2008). Soil NO fluxes have never been reported from rubber or oil palm plantations. Our present study provides the first soil $\mathrm{N}$-oxide flux measurements from these land uses with sufficient temporal coverage and spatial replications at the landscape scale.

In contrast to our second hypothesis, soil $\mathrm{N}$-oxide fluxes were comparable among land uses (except for soil NO fluxes between rubber and jungle rubber in the loam Acrisol landscape as discussed below), even with the observed decreases in soil mineral $\mathrm{N}$ levels among land uses (i.e., generally lower $\mathrm{NH}_{4}{ }^{+}$and $\mathrm{NO}_{3}{ }^{-}$levels in rubber plantations than in the reference land uses at both landscapes; Appendix Table A3.2). In the same study sites, Allen et al. (2015) found differences in other indices of soil $\mathrm{N}$ availability with land-use change, particularly in the clay 
Acrisol landscape: microbial $\mathrm{C}$ and $\mathrm{N}$, gross $\mathrm{N}$ mineralization and $\mathrm{NH}_{4}{ }^{+}$immobilization rates decrease with conversion of forest to rubber or oil palm plantations. N-oxide emissions generally account only a small fraction of soil available $\mathrm{N}$ (e.g., $\mathrm{N}_{2} \mathrm{O}+\mathrm{NO}$ emissions comprise $0.03 \%$ of gross $\mathrm{N}$ mineralization rates in a lowland forest on Cambisol and Nitisols soils in Panama; Corre et al., 2014). In our present study, the reference land uses on highly weathered Acrisol soils have low soil $\mathrm{N}$ availability and their conversion to these plantations further decreases the soil $\mathrm{N}$-cycling rates (Allen et al., 2015). Hence, we reason that we did not detect differences in N-oxide fluxes with land-use conversion to rubber and oil palm plantations because we started with low soil $\mathrm{N}$ availability and low $\mathrm{N}$-oxide emissions and any changes were probably too small to detect statistically. The temporal pattern of soil $\mathrm{N}_{2} \mathrm{O}$ fluxes in the converted land uses were also controlled by soil $\mathrm{NO}_{3}{ }^{-}$contents (Table 3.3), emphasizing the first level of control of soil $\mathrm{N}$ availability on soil $\mathrm{N}_{2} \mathrm{O}$ fluxes (HIP model; Davidson et al., 2000). Across landscapes, the correlations of annual soil $\mathrm{N}_{2} \mathrm{O}$ fluxes from these converted land uses with sand contents (see Sect. 3.3) also suggested the indirect influence of soil texture on water holding capacity, or conversely soil aeration status, which is the second level of control on soil $\mathrm{N}_{2} \mathrm{O}$ fluxes (HIP model). Consequently, in terms of N-oxide emissions, this footprint of smallholder oil palm and rubber plantations was similar to the original land uses. However, this picture might change with increasing usage of $\mathrm{N}$ fertilizer (see next section).

The lower soil NO fluxes in rubber compared to jungle rubber in the loam Acrisol (Table 3.1) partly supports our second hypothesis. These differences might be related to the low WFPS and the higher soil $\mathrm{NO}_{3}{ }^{-}$contents in jungle rubber (Appendix Table A3.2), which could favor the relatively high soil NO emissions; this was also supported by the opposing correlations of soil $\mathrm{NO}$ with $\mathrm{NO}_{3}{ }^{-}$and WFPS (Table 3.3). Additionally, the low soil NO fluxes from rubber plantations could be the result of the effect of monoterpenes, produced by rubber trees, which reduce nitrification in soil (Wang et al., 2007; White, 1991). This is supported by low gross nitrification rates (measured in the same plots by Allen et al., 2015), low soil $\mathrm{NO}_{3}{ }^{-}$contents (Appendix Table A3.2) and consequently low soil NO fluxes in rubber plantations (Table 3.1). 


\section{Soil management effects on soil $\mathrm{N}_{2} \mathrm{O}$ and $\mathrm{NO}$ fluxes from oil palm plantations}

$\mathrm{N}$ fertilizer application, a commonly employed soil management in oil palm plantations (e.g., Allen et al., 2015; Hassler et al., 2015), increases N-oxide emission for a relatively short period (e.g., Koehler et al. 2009). Our findings show that these fertilizer-induced N-oxide emissions were mainly limited to the small area around the palm base where fertilizer is commonly applied ( $4 \%$ of the area in a hectare) and that N-oxide emissions peaked within 3 weeks (Figs. 3.2 and 3.3). These $\mathrm{N}$-fertilizer induced $\mathrm{N}_{2} \mathrm{O}$ fluxes of $6-21 \%$ of the annual soil $\mathrm{N}_{2} \mathrm{O}$ fluxes were similar in magnitude as the standard errors of the annual fluxes (estimated from the monthly measurements; Table 3.1). Thus, inclusion of these $\mathrm{N}$-induced emissions in our annual estimates did not result in statistically significant effects of land-use change.

The percentages of soil $\mathrm{N}_{2} \mathrm{O}$ and $\mathrm{NO}$ fluxes to the applied $\mathrm{N}$ fertilizer rate were smaller than those reported from other agricultural land uses in humid tropical regions (6.4-8.6\%; Veldkamp and Keller, 1997; Veldkamp et al., 1998). Usually the percentage of soil N-oxide emissions to applied $\mathrm{N}$ fertilizer rate increases with increasing $\mathrm{N}$ fertilization rates (Hoben et al., 2011; Pennock and Corre, 2001). Since the fertilization rates in our studied smallholder oil palm plantations were lower compared to the fertilization rates in these other studies (with $\mathrm{N}$ fertilization rates ranging from $300-360 \mathrm{~kg} \mathrm{~N} \mathrm{ha}^{-1} \mathrm{yr}^{-1}$ ), our quantified $\mathrm{N}$-oxide loss from $\mathrm{N}$ fertilizer were also low. The higher soil $\mathrm{N}_{2} \mathrm{O}$ fluxes in the large-scale oil palm plantation PTPN VI, although not statistically different from the smallholder plantations (Table 3.1), could be attributed to its high $\mathrm{N}$ fertilization rate $\left(196 \mathrm{~kg} \mathrm{~N} \mathrm{ha}^{-1} \mathrm{yr}^{-1}\right)$. Summing the $\mathrm{N}$-induced $\mathrm{N}$-oxide fluxes and the annual soil N-oxide emissions based on the monthly measurements (Table 3.1), these values from the smallholder plantations were still lower than the annual flux from the large-scale plantation (Table 3.1). Based on our finding that soil $\mathrm{N}_{2} \mathrm{O}$ fluxes following fertilizer application (chamber location b) were higher in the clay than loam Acrisol landscapes (most likely due to higher WFPS in the clay $(61 \pm 8 \%)$ than loam Acrisol $(27 \pm 3 \%)$ during this measurement period), soil $\mathrm{N}$-oxide fluxes from large-scale plantations on clay soils could be even higher than what we measured here from a large-scale plantation on a loam soil. Our findings reinforced the need to quantify these climate-relevant $\mathrm{N}$-oxide gases in large-scale plantations, which constitute $\sim 50 \%$ of the land area under oil palm plantation in whole of Sumatra (BPS, 2014). 
Temporal patterns in soil N-oxide fluxes following fertilizer application were also controlled by soil $\mathrm{N}$ availability, as reflected by their positive correlations with soil $\mathrm{NH}_{4}{ }^{+}$and/or $\mathrm{NO}_{3}{ }^{-}$contents (Table 3.4). The pulse application of $\mathrm{N}$ fertilizer provide temporary surplus of mineral $\mathrm{N}$ that was lost via gaseous emission and leaching (Kurniawan, 2016), and with time following fertilizer application such effect diminished as the mineral $\mathrm{N}$ is incorporated into the soil N-cycling processes (Allen et al., 2015). The positive correlation between soil $\mathrm{N}_{2} \mathrm{O}$ fluxes and WFPS (i.e., chamber locations $\mathrm{a}$ and $\mathrm{b}$ in site 1 of the loam Acrisol; Table 3.4) and the negative correlation between soil NO fluxes and WFPS (i.e., chamber location $b$ in site 3 of the clay Acrisol landscape; Table 3.4) again attested that when the first level of control (soil $\mathrm{N}$ availability) was favorable (i.e., high soil mineral $\mathrm{N}$ contents in these fertilized chamber locations) the control of soil moisture on aeration status was enhanced, as such correlation was not seen in the unfertilized area (chamber location c) or in the monthly measured fluxes (Tables 3.3 and 3.4). These correlations indicated that following fertilizer application soil NO fluxes decreased whereas soil $\mathrm{N}_{2} \mathrm{O}$ fluxes increased with increases in WFPS. In site 3 of the loam Acrisol, the seemingly contradicting negative correlation of soil $\mathrm{N}_{2} \mathrm{O}$ fluxes with WFPS (Table 3.4) was only because there was a decreasing WFPS following fertilizer application with concurrently increasing soil mineral $\mathrm{N}$ contents - the latter dominantly driving the increases in soil $\mathrm{N}_{2} \mathrm{O}$ fluxes (i.e., positive correlations with $\mathrm{NH}_{4}{ }^{+}$and $\mathrm{NO}_{3}{ }^{-}$; Table 3.4). In summary, the short-term effect of fertilization also depicted the two levels of controls on soil N-oxide fluxes as exemplified in the HIP model.

\subsection{Conclusions}

Our study provides the first spatially replicated study with a full year of measurements of soil $\mathrm{N}_{2} \mathrm{O}$ fluxes and the first reported soil NO fluxes from this region of hotspot of land-use conversion for globally important tree cash crops. In contrast to our first hypothesis, soil texture, through its role on soil fertility, did not directly affect soil N-oxide fluxes (as shown by the comparable fluxes between landscapes with soil textural differences) but influenced the landscape-scale pattern of annual soil $\mathrm{N}_{2} \mathrm{O}$ fluxes in the converted land uses (i.e., negative correlation between annual $\mathrm{N}_{2} \mathrm{O}$ fluxes and sand content) most likely through its role on soil moisture availability. The generally low soil N-oxide fluxes from the reference land uses were 
due to the low soil $\mathrm{N}$ availability in these highly weathered Acrisol soils (Allen et al., 2015). Forest or jungle rubber conversion to rubber and oil palm by smallholders also did not show significant changes in soil N-oxide fluxes, except for the decrease in soil NO fluxes in rubber plantations and for the short-term pulse of soil $\mathrm{N}$-oxide fluxes following fertilizer application in oil palm plantations. These partly support our second hypothesis. Using a conservative estimate of $\mathrm{N}$-oxide $\left(\mathrm{N}_{2} \mathrm{O}+\mathrm{NO}\right.$ ) loss from the applied $\mathrm{N}$ fertilizer (average of $0.5 \%$ from the loam and clay Acrisol landscapes), and a conservative average $\mathrm{N}$ fertilization rate across smallholder and large-scale plantations of $100 \mathrm{~kg} \mathrm{~N} \mathrm{ha}^{-1} \mathrm{yr}^{-1}$, with the total land area of oil palm in Jambi Province of 721000 ha (BPS, 2014), we estimated an annual soil N-oxide emission from N fertilization of $360500 \mathrm{~kg} \mathrm{~N} \mathrm{yr}^{-1}$. The $\mathrm{N}$ fertilization rates in our smallholder oil palm plantations were only about one-fourth to one-half of what is commonly practiced in large-scale industrial plantations (e.g., 130-260 $\mathrm{kg} \mathrm{N} \mathrm{ha}^{-1} \mathrm{yr}^{-1}$ in Jambi, Indonesia; Pahan, 2010), and our measurements from a large-scale oil palm plantation PTPN VI showed high soil N-oxide fluxes. To improve estimate of soil N-oxide fluxes at regional level, future studies should focus on large-scale plantations (which constitute $38 \%$ of oil palm land area in Jambi Province; BPS, 2014) with frequent measurements during 2 months following fertilizer application, and particularly during wet season for $\mathrm{N}_{2} \mathrm{O}$ flux measurements and during dry season for NO flux measurements.

Acknowledgments. We thank the village leaders, local plot owners, PT REKI, PTPN VI, and Bukit Duabelas National Park for granting us access and use of their properties. This study was financed by the Deutsche Forschungsgemeinschaft (DFG) as part of the project A05 (SFB 990/2) in the framework of the German-Indonesian Collaborative Research Center 990: Ecological and Socioeconomic Function of Tropical Lowland Rainforest Transformation Systems. We are especially grateful to our Indonesian assistants, Edward Januarlin Siahaan, Nelson Apriadi Silalahi, Ardi, Fahrurrozy, Edi, Bayu Puja Kesuma, Basri, Darwis and Suriana as well as all the rangers of the protected forest areas. We also acknowledge project A03 for helping part of the gas sampling in PTPN VI, both A03 and the Indonesian Meteorological, Climatological and Geophysical Agency for climatic data, as well as the other members of project A05 (Allen et al., 2015) for the soil physical and biochemical data (Appendix Table A3.1), and also B04 
(Kotowska et al., 2015) and B06 (Rembold et al., unpublished data) for providing vegetation data. We thank Norman Loftfield, Oliver van Straaten, Andrea Bauer, Kerstin Langs and Martina Knaust (Georg-August University Göttingen, Germany) for their assistance with laboratory analyses. This study was conducted using the research permits (210/SIP/FRP/SM/VI/2012 and 45/EXT/SIP/FRP/SM/V/2013) from the Ministry of Research and Technology of Indonesia (RISTEK), and the collection permits (2703/IPH.1/KS.02/XI/2012 and S.13/KKH-2/2013) from the Indonesian Institute of Sciences (LIPI) and the Ministry of Forestry (PHKA). 


\section{Appendix}

Table A3.1. Mean $( \pm$ SE, $n=4$ sites) soil physical and biochemical characteristics in the top $0.10 \mathrm{~m}$ depth (except sand content with $n=3$ sites) from different land uses within each landscape in Jambi, Sumatra, Indonesia. Means followed by different lowercase letters indicate significant differences among land uses within each landscape and different capital letter indicate significant differences between landscapes within each land use (linear mixed-effect models with Fisher's LSD test at $P \leq 0.05$ and marginally significant at $* \leq 0.09$ ). These soil characteristics were reported by Allen et al. (2015), except for the sand content (Allen et al., unpublished data).

\begin{tabular}{|c|c|c|c|c|}
\hline \multirow[b]{2}{*}{ Soil characteristics } & \multicolumn{4}{|c|}{ Land-use type } \\
\hline & Forest & Jungle rubber & Rubber & Oil palm \\
\hline \multicolumn{5}{|l|}{ clay Acrisol landscape } \\
\hline Sand $(\%)$ & $36 \pm 11^{\mathrm{a}}$ & $27 \pm 20^{\mathrm{a}}$ & $35 \pm 7^{\mathrm{a}}$ & $11 \pm 2^{\mathrm{a}, \mathrm{B}^{*}}$ \\
\hline Soil C:N ratio & $13.1 \pm 1.3^{\mathrm{a}}$ & $13.0 \pm 0.3^{\mathrm{a}}$ & $14.3 \pm 0.6^{\mathrm{a}, \mathrm{A}}$ & $13.5 \pm 0.2^{\mathrm{a}}$ \\
\hline Microbial C $\left(\mathrm{mg} \mathrm{C} \mathrm{kg}^{-1}\right)$ & $1048 \pm 201^{\mathrm{a}^{*}, \mathrm{~A}}$ & $922 \pm 223^{\mathrm{ab}^{*}}$ & $561 \pm 61^{c^{*}}$ & $617 \pm 112^{\mathrm{bc} *}$ \\
\hline Gross nitrification $\left(\mathrm{mg} \mathrm{N} \mathrm{kg}^{-1}\right.$ day $\left.^{-1}\right)$ & $0.9 \pm 0.3^{\mathrm{a}}$ & $1.0 \pm 0.2^{\mathrm{a}}$ & $0.7 \pm 0.2^{\mathrm{a}}$ & $2.0 \pm 0.8^{\mathrm{a}}$ \\
\hline \multicolumn{5}{|l|}{ loam Acrisol landscape } \\
\hline Sand $(\%)$ & $39 \pm 8^{\mathrm{a}}$ & $42 \pm 19^{a}$ & $26 \pm 13^{\mathrm{a}}$ & $43 \pm 14^{\mathrm{a}, \mathrm{A}^{*}}$ \\
\hline Soil C:N ratio & $14.3 \pm 0.2^{\mathrm{a}}$ & $13.7 \pm 0.8^{\mathrm{a}}$ & $11.7 \pm 0.7^{\mathrm{b}, \mathrm{B}}$ & $12.5 \pm 0.5^{\mathrm{ab}}$ \\
\hline Microbial C $\left(\mathrm{mg} \mathrm{C} \mathrm{kg}^{-1}\right)$ & $514 \pm 48^{\mathrm{a}, \mathrm{B}}$ & $578 \pm 45^{\mathrm{a}}$ & $461 \pm 58^{\mathrm{a}}$ & $403 \pm 24^{\mathrm{a}}$ \\
\hline Gross nitrification $\left(\mathrm{mg} \mathrm{N} \mathrm{kg}^{-1}\right.$ day $\left.^{-1}\right)$ & $1.9 \pm 0.4^{\mathrm{a}}$ & $0.9 \pm 0.2^{\mathrm{a}}$ & $0.9 \pm 0.2^{\mathrm{a}}$ & $1.2 \pm 0.5^{\mathrm{a}}$ \\
\hline
\end{tabular}


Table A3.2. Mean ( \pm SE, $n=4$ sites) soil water-filled pore space (WFPS) and extractable mineral $\mathrm{N}$ in the top $0.05 \mathrm{~m}$ depth for different land uses within each landscape in Jambi, Sumatra, Indonesia, measured monthly from December 2012 to December 2013. Means followed by different lowercase letters indicate significant differences among land uses within each landscape and different capital letters indicate significant differences between landscapes within each land use (linear mixed-effect models with Fisher's least significant difference (LSD) test at $P \leq 0.05$ ). These soil characteristics were reported by Hassler et al. (2015).

\begin{tabular}{llll}
\hline Land-use type & $\begin{array}{l}\text { WFPS } \\
(\%)\end{array}$ & $\begin{array}{l}\mathrm{NH}_{4}^{+} \\
\left(\mathrm{mg} \mathrm{N} \mathrm{kg}^{-1}\right)\end{array}$ & $\begin{array}{l}\mathrm{NO}^{-} \\
\left(\mathrm{mg} \mathrm{N} \mathrm{kg}^{-1}\right)\end{array}$ \\
\hline clay Acrisol landscape & & & \\
\hline Forest & $72.97 \pm 12.31^{\mathrm{a}, \mathrm{A}}$ & $6.99 \pm 1.03^{\mathrm{a}, \mathrm{A}}$ & $2.15 \pm 0.36^{\mathrm{a}, \mathrm{A}}$ \\
Jungle rubber & $86.74 \pm 5.93^{\mathrm{a}, \mathrm{A}}$ & $7.33 \pm 0.21^{\mathrm{a}, \mathrm{A}}$ & $0.23 \pm 0.06^{\mathrm{b}, \mathrm{B}}$ \\
Rubber & $61.49 \pm 7.41^{\mathrm{a}, \mathrm{A}}$ & $4.25 \pm 0.23^{\mathrm{b}, \mathrm{A}}$ & $0.05 \pm 0.01^{\mathrm{b}, \mathrm{B}}$ \\
Oil Palm & $74.03 \pm 7.28^{\mathrm{a}, \mathrm{A}}$ & $5.80 \pm 0.64^{\mathrm{a}, \mathrm{A}}$ & $0.81 \pm 0.49^{\mathrm{b}, \mathrm{A}}$ \\
\hline loam Acrisol landscape & & & $0.61 \pm 0.15^{\mathrm{ab}, \mathrm{B}}$ \\
\hline Forest & $63.97 \pm 3.30^{\mathrm{a}, \mathrm{A}}$ & $5.94 \pm 0.40^{\mathrm{a}, \mathrm{A}}$ & $1.25 \pm 0.63^{\mathrm{a}, \mathrm{A}}$ \\
Jungle rubber & $53.86 \pm 3.70^{\mathrm{a}, \mathrm{B}}$ & $5.64 \pm 0.28^{\mathrm{a}, \mathrm{B}}$ & $0.12 \pm 0.02^{\mathrm{b}, \mathrm{A}}$ \\
Rubber & $72.58 \pm 5.73^{\mathrm{a}, \mathrm{A}}$ & $4.14 \pm 0.57^{\mathrm{b}, \mathrm{A}}$ & $0.60 \pm 0.36^{\mathrm{ab}, \mathrm{B}}$ \\
\hline
\end{tabular}




\section{References}

Aini, F. K., Hergoualc'h, K., Smith, J. U., and Verchot, L.: Nitrous oxide emissions along a gradient of tropical forest disturbance on mineral soils in Sumatra, Agr. Ecosyst. Environ., 214, 107-117, 2015.

Allen, K., Corre, M. D., Tjoa, A., and Veldkamp, E.: Soil nitrogen-cycling responses to conversion of lowland forests to oil palm and rubber plantations in Sumatra, Indonesia, PLoS ONE, 10, e0133325, 2015.

BPS (Badan Pusat Statistik): Indonesian oil palm statistics 2013, BPS, Jakarta, Indonesia, 2014.

BPS (Badan Pusat Statistik): Plantation area by province and crops, Indonesia, 2012-2014, available at: http://www.bps.go.id/linkTableDinamis/view/id/838 (last access: 7 April 2016), 2016a.

BPS (Badan Pusat Statistik): Production of plantation crops by province and crops, Indonesia, 2012-2014, available at: http://www.bps.go.id/linkTableDinamis/view/id/839 (last access: 27 June 2016), 2016b.

Breuer, L., Papen, H., and Butterbach-Bahl, K.: $\mathrm{N}_{2} \mathrm{O}$ emission from tropical forest soils of Australia, J. Geophys. Res., 105, 26353-26367, 2000.

Castaldi, S., Bertolini, T., Valente, A., Chiti, T., and Valentini, R.: Nitrous oxide emissions from soil of an African rain forest in Ghana, Biogeosciences, 10, 4179-4187, 2013.

Conrad, R.: Compensation concentration as critical variable for regulating the flux of trace gases between soil and atmosphere, Biogeochemistry, 27, 155-170, 1994.

Conrad, R.: Soil microorganisms as controllers of atmospheric trace gases $\left(\mathrm{H}_{2}, \mathrm{CO}, \mathrm{CH}_{4}, \mathrm{OCS}\right.$, $\mathrm{N}_{2} \mathrm{O}$, and NO), Microbiol. Rev., 60, 609-640, 1996.

Corre, M. D., Veldkamp, E., Arnold, J., and Wright, S. J.: Impact of elevated N input on soil N cycling and losses in old-growth lowland and montane forests in Panama, Ecology, 91, 17151729, 2010.

Corre, M. D., Sueta, J. P., and Veldkamp, E.: Nitrogen-oxide emissions from tropical forest soils 
exposed to elevated nitrogen input strongly interact with rainfall quantity and seasonality, Biogeochemistry, 118, 103-120, 2014.

Crawley, M. J.: The R Book, John Wiley \& Sons Ltd, Chichester, UK, 2007.

Davidson, E. A. and Kingerlee, W.: A global inventory of nitric oxide emissions from soils, Nutr. Cycl. Agroecosys., 48, 37-50, 1997.

Davidson, E. A., Keller, M., Erickson, H. E., Verchot, L. V., and Veldkamp, E.: Testing a conceptual model of soil emissions of nitrous and nitric oxides, Bioscience, 50, 667-680, 2000.

Davidson, E. A., Ishida, F. Y., and Nepstad, D. C.: Effects of an experimental drought on soil emissions of carbon dioxide, methane, nitrous oxide, and nitric oxide in a moist tropical forest, Glob. Change Biol., 10, 718-730, 2004.

FAO (Food and Agricultural Organization): FAOSTAT database, available at: http://faostat3.fao.org/browse/Q/QC/E (last access 22 March 2016), 2016.

Field, R. D., van der Werf, G. R., and Shen, S. S. P.: Human amplification of drought-induced biomass burning in Indonesia since 1960, Nat. Geosci., 2, 185-188, 2009.

Firestone, M. K. and Davidson, E. A.: Microbiological basis of $\mathrm{NO}$ and $\mathrm{N}_{2} \mathrm{O}$ production and consumption in soil, in: Exchange of trace gases between terrestrial ecosystems and the atmosphere, edited by: Andreae, M. O. and Schimel, D. S., John Wiley \& Sons Ltd, New York, USA, 7-21, 1989.

Hassler, E., Corre, M. D., Tjoa, A., Damris, M., Utami, S. R., and Veldkamp, E.: Soil fertility controls soil-atmosphere carbon dioxide and methane fluxes in a tropical landscape converted from lowland forest to rubber and oil palm plantations, Biogeosciences, 12, 5831-5852, 2015.

Heinen, M.: Simplified denitrification models: Overview and properties, Geoderma, 133, 444463, 2006.

Hoben, J. P., Gehl, R. J., Millar, N., Grace, P. R., and Robertson, G. P.: Nonlinear nitrous oxide $\left(\mathrm{N}_{2} \mathrm{O}\right)$ response to nitrogen fertilizer in on-farm corn crops of the US Midwest, Glob. Change Biol., 17, 1140-1152, 2011. 
IPCC: Climate Change 2013: The physical science basis, contribution of working group I to the fifth assessment report of the intergovernmental panel on climate change, Cambridge University Press, Cambridge, UK, New York, USA, 2013.

Ishizuka, S., Tsuruta, H., and Murdiyarso, D.: An intensive field study on $\mathrm{CO}_{2}, \mathrm{CH}_{4}$, and $\mathrm{N}_{2} \mathrm{O}$ emissions from soils at four land-use types in Sumatra, Indonesia, Global Biogeochem. Cy., 16, 22-1-22-11, 2002.

Ishizuka, S., Iswandi, A., Nakajima, Y., Yonemura, S., Sudo, S., Tsuruta, H., and Murdiyarso, D.: The variation of greenhouse gas emissions from soils of various land-use/cover types in Jambi province, Indonesia, Nutr. Cycl. Agroecosys., 71, 17-32, 2005.

Jacob, D. and Bakwin, P.: Cycling of NOx in tropical forest canopies, in: Microbial production and consumption of greenhouse gases: methane, nitrogen oxides and halomethanes, edited by: Rogers, J. E. and Whitman, W. B., American Society for Microbiology, Washington, DC, USA, 237-253, 1991.

Keller, M. and Reiners, W. A.: Soil-atmosphere exchange of nitrous oxide, nitric oxide, and methane under secondary succession of pasture to forest in the Atlantic lowlands of Costa Rica, Global Biogeochem. Cy., 8, 399-409, 1994.

Keller, M., Varner, R., Dias, J. D., Silva, H., Crill, P., de Oliveira, R. C., and Asner, G. P.: Soilatmosphere exchange of nitrous oxide, nitric oxide, methane, and carbon dioxide in logged and undisturbed forest in the Tapajos National Forest, Brazil, Earth Interact., 9, 1-28, 2005.

Koehler, B., Corre, M. D., Veldkamp, E., Wullaert, H., and Wright, S. J.: Immediate and longterm nitrogen oxide emissions from tropical forest soils exposed to elevated nitrogen input, Glob. Change Biol., 15, 2049-2066, 2009.

Kotowska, M. M., Leuschner, C., Triadiati, T., Meriem, S., and Hertel, D.: Quantifying above and belowground biomass carbon loss with forest conversion in tropical lowlands of Sumatra (Indonesia), Glob. Change Biol., 21, 3620-3634, 2015.

Kurniawan, S.: Conversion of lowland forests to rubber and oil palm plantations changes nutrient leaching and nutrient retention efficiency in highly weathered soils of Sumatra, Indonesia 
(Doctoral dissertation, Faculty of Forest Sciences and Forest Ecology, Georg-August University of Goettingen), available at: http://hdl.handle.net/11858/00-1735-0000-0028-8706-8 (last access: 25.05.2016), 2016.

Lammel, G. and Graß1, H.: Greenhouse effect of NOx., Environ. Sci. Pollut. R., 2, 40-45, 1995.

Laumonier, Y., Uryu, Y., Stüwe, M., Budiman, A., Setiabudi, B., and Hadian, O.: Eco-floristic sectors and deforestation threats in Sumatra: Identifying new conservation area network priorities for ecosystem-based land use planning, Biodivers. Conserv., 19, 1153-1174, 2010.

Lestari, R. K., Watanabe, M., Imada, Y., Shiogama, H., Field, R. D., Takemura, T. and, Kimoto, M.: Increasing potential of biomass burning over Sumatra, Indonesia induced by anthropogenic tropical warming, Environ. Res. Lett., 9, 104010, 2014.

Levine, J. S.: The 1997 fires in Kalimantan and Sumatra, Indonesia: Gaseous and particulate emissions, Geophys. Res. Lett., 26, 815-818, 1999.

Margono, B. A., Turubanova, S., Zhuravleva, I., Potapov, P., Tyukavina, A., Baccini, A., Goetz, S., and Hansen, M. C.: Mapping and monitoring deforestation and forest degradation in Sumatra (Indonesia) using Landsat time series data sets from 1990 to 2010, Environ. Res. Lett., 7, 034010, 2012.

Matson, P. A., Billow, C., Hall, S., and Zachariassen, J.: Fertilization practices and soil variations control nitrogen oxide emissions from tropical sugar cane, J. Geophys. Res.-Atmos., 101, 18533-18545, 1996.

Müller, A. K., Matson, A. L., Corre, M. D., and Veldkamp, E.: Soil $\mathrm{N}_{2} \mathrm{O}$ fluxes along an elevation gradient of tropical montane forests under experimental nitrogen and phosphorus addition, Front. Earth Sci., 3, 1-12, 2015.

Pahan, I.: Panduan lengkap kelapa sawit [translation: Complete guide to oil palm], Penebar Swadaya, Jakarta, Indonesia, 2010.

Pennock, D. J. and Corre, M. D.: Development and application of landform segmentation procedures, Soil Till. Res., 58, 151-162, 2001. 
Pilegaard, K.: Processes regulating nitric oxide emissions from soils, Philos. T. R. Soc. B, 368, $20130126,2013$.

Purbopuspito, J., Veldkamp, E., Brumme, R., and Murdiyarso, D.: Trace gas fluxes and nitrogen cycling along an elevation sequence of tropical montane forests in Central Sulawesi, Indonesia, Global Biogeochem. Cy., 20, 2006.

R Development Core Team: R: A language and environment for statistical computing, $\mathrm{R}$ Foundation for Statistical Computing, Vienna, Austria., 2015.

Ravishankara, A. R., Daniel, J. S., and Portmann, R. W.: Nitrous oxide $\left(\mathrm{N}_{2} \mathrm{O}\right)$ : the dominant ozone-depleting substance emitted in the 21st century, Science, 326, 123-125, 2009.

Skiba, U. and Smith, K. A.: The control of nitrous oxide emissions from agricultural and natural soils, Chemosphere - Glob. Chang. Sci., 2, 379-386, 2000.

Sparks, J. P., Monson, R. K., Sparks, K. L., and Lerdau, M.: Leaf uptake of nitrogen dioxide $\left(\mathrm{NO}_{2}\right)$ in a tropical wet forest: Implications for tropospheric chemistry, Oecologia, 127, 214-221, 2001.

Veldkamp, E. and Keller, M.: Nitrogen oxide emissions from a banana plantation in the humid tropics, J. Geophys. Res., 102, 15889-15898, 1997.

Veldkamp, E., Keller, M., and Nuñez, M.: Effects of pasture management on $\mathrm{N}_{2} \mathrm{O}$ and NO emissions from soils in the humid tropics of Costa Rica, Global Biogeochem. Cy., 12, 71-79, 1998.

Veldkamp, E., Purbopuspito, J., Corre, M. D., Brumme, R., and Murdiyarso, D.: Land use change effects on trace gas fluxes in the forest margins of Central Sulawesi, Indonesia, J. Geophys. Res., 113, G02003, 2008.

Verchot, L. V., Davidson, E. A., Cattânio, J. H., Ackerman, I. L., Erickson, H. E., and Keller, M.: Land use change and biogeochemical controls of nitrogen oxide emissions from soils in eastern Amazonia, Global Biogeochem. Cy., 13, 31-46, 1999.

Wang, Y. F., Owen, S. M., Li, Q. J., and Peñuelas, J.: Monoterpene emissions from rubber trees 
(Hevea brasiliensis) in a changing landscape and climate: chemical speciation and environmental control, Glob. Change Biol., 13, 2270-2282, 2007.

Werner, C., Zheng, X., Tang, J., Xie, B., Liu, C., Kiese, R., and Butterbach-Bahl, K.: $\mathrm{N}_{2} \mathrm{O}, \mathrm{CH}_{4}$ and $\mathrm{CO}_{2}$ emissions from seasonal tropical rainforests and a rubber plantation in Southwest China, Plant Soil, 289, 335-353, 2006.

Werner, C., Butterbach-Bahl, K., Haas, E., Hickler, T., and Kiese, R.: A global inventory of $\mathrm{N}_{2} \mathrm{O}$ emissions from tropical rainforest soils using a detailed biogeochemical model, Global Biogeochem. Cy., 21, 2007.

White, C. S.: The role of monoterpenes in soil nitrogen cycling processes in ponderosa pine results from laboratory bioassays and field studies, Biogeochemistry, 12, 43-68, 1991.

Yashiro, Y., Kadir, W. R., Adachi, M., Okuda, T., and Koizumi, H.: Emission of nitrous oxide from tropical forest and plantation soils in Peninsular Malaysia, Tropics, 17, 17-23, 2008. 


\title{
Chapter 4
}

\section{Canopy soil of oil palm plantations emits methane and nitrous oxide}

\section{Submitted to Soil Biology and Biochemistry}

\author{
Evelyn Hassler, Kara Allen, Syahrul Kurniawan, Edzo Veldkamp, Marife D. Corre
}

\begin{abstract}
Due to an increasing global demand in cheaper oils and biofuels, forest conversion to oil palm plantations is rapidly increasing in Indonesia. Oil palm canopy soil, or the soil lodged between the stems and leaf axils of oil palms, is one ecosystem compartment that has yet to be investigated as to its importance on the soil greenhouse gas budget. Our objectives were (1) to quantify nitrous oxide $\left(\mathrm{N}_{2} \mathrm{O}\right)$ and methane $\left(\mathrm{CH}_{4}\right)$ fluxes from oil palm canopy soil, and (2) to determine the factors controlling these fluxes. Our study was conducted in Jambi Province, Indonesia, where we selected eight smallholder oil palm plantations (9-16 years old) and established one $50 \mathrm{~m}$ x $50 \mathrm{~m}$ plot within each plantation. Each plot was represented by five oil palms, and each oil palm stem was delineated into three 1-m sections (low, middle, and top) in order to represent possible gradients of canopy soil conditions that influence $\mathrm{N}_{2} \mathrm{O}$ and $\mathrm{CH}_{4}$ fluxes. Measurements were conducted from February 2013 to May 2014 alternating among the eight plots. Trace gas fluxes were measured by collecting canopy soil from each stem section and incubating it in-situ in an air-tight glass jar. Canopy soils from all oil palm stem sections emitted $\mathrm{N}_{2} \mathrm{O}$ and $\mathrm{CH}_{4}$. The top stem section had higher $\mathrm{N}_{2} \mathrm{O}$ and $\mathrm{CH}_{4}$ emissions than the lower sections, and this pattern was paralleled by nitrogen availability and water content, which strongly influenced these fluxes. Canopy soil greenhouse gas emissions per unit dry mass of canopy soil were considerable, but on a hectare basis these emissions were small due to the low amount of canopy soil per hectare $\left(170 \mathrm{~kg} \mathrm{ha}^{-1}\right)$. Annual canopy soil $\mathrm{N}_{2} \mathrm{O}$ and $\mathrm{CH}_{4}$ emissions were $10.7 \pm 3.3 \mathrm{~g} \mathrm{~N}_{2} \mathrm{O}-\mathrm{N} \mathrm{ha}^{-1} \mathrm{yr}^{-1}$ and $1.9 \pm 0.5 \mathrm{~g} \mathrm{CH}_{4}-\mathrm{C} \mathrm{ha}^{-1} \mathrm{yr}^{-1}$, respectively, which contributed only $1 \%$ of the total soil (canopy soil + ground soil) $\mathrm{N}_{2} \mathrm{O}$ fluxes and $0.2 \%$ of the ground soil net $\mathrm{CH}_{4}$ consumption. Our estimate of oil palm canopy soil emissions in Jambi Province were 7.7 $\mathrm{Mg} \mathrm{N}_{2} \mathrm{O}-\mathrm{N} \mathrm{yr}^{-1}$ and $1.3 \mathrm{Mg} \mathrm{CH}_{4}-\mathrm{C} \mathrm{yr}^{-1}$. Considering the increasing areal coverage of oil palm plantations in Southeast Asia, these fluxes could potentially have substantial contribution to soil greenhouse gas budget.
\end{abstract}




\subsection{Introduction}

Oil palm (Elaeis guineensis) is a rapidly expanding land use across Southeast Asia, especially in Indonesia, with a majority of expansion occurring during the last two decades (Carlson et al., 2013). From 2000-2010, the area under oil palm in Indonesia increased by four million hectares (ha; FAO, 2016). Subsequently, deforestation rates across Indonesia and especially in Sumatra have also remained high, with an approximately $17 \%$ decrease in forest cover in Sumatra between 2000-2012 (Margono et al., 2014). In Jambi Province, Sumatra, Indonesia, during the period 1990-2011 the land under oil palm increased by $150 \%$, most likely due to the increasing global demand for cheap oils and biofuels, as well as the overall higher economic gains and lower labor costs of cultivating oil palm (Clough et al., 2016).

Though oil palm can be economically profitable, the conversion of forest to monoculture oil palm plantations by smallholders in Jambi Province, Indonesia has shown high ecological costs. There are decreases in soil nitrogen $(\mathrm{N})$-cycling rates and microbial biomass particularly in soils with high initial fertility (Allen et al., 2015) along with increases in nutrient leaching losses (Kurniawan, 2016). Likewise there are significant decreases in below- and aboveground organic carbon (C) stocks (Kotowska et al., 2015; van Straaten et al., 2015) and decreases in soil carbon dioxide $\left(\mathrm{CO}_{2}\right)$ emissions as a result of strongly decomposed soil organic matter and reduced soil C stocks (Hassler et al., 2015). Lower soil $\mathrm{N}$ availability, which limits methanotrophic activity, also led to decreases in methane $\left(\mathrm{CH}_{4}\right)$ uptake from the atmosphere in oil palm plantations (Hassler et al., 2015). Moreover, from the same smallholder oil palm plantations in Jambi, where our present study was conducted, $\mathrm{N}$ fertilization on small localized areas around the base of oil palms resulted in pulse increases of soil nitric oxide $(\mathrm{NO})$ and nitrous oxide $\left(\mathrm{N}_{2} \mathrm{O}\right)$ emissions for about two months following fertilization (Hassler et al., 2016).

Aside from the changes in sources and sinks of trace gases in the soil from conversion of forest to oil palm plantations, the oil palm canopy could also be a substantial source and/or sink of climate-relevant trace gases. Higher fluxes of volatile organic compounds and $\mathrm{NO}_{\mathrm{x}}$ over oil palm canopies compared to rainforest have been reported (Fowler et al., 2011; Hewitt et al., 2009; MacKenzie et al., 2011). From our earlier works in tropical forests, we have identified that tank bromeliads are an important source of $\mathrm{CH}_{4}$ from the forest canopy. Bromeliad tanks gather organic debris and water on their leaf axils, forming a 'wetland' environment conducive to $\mathrm{CH}_{4}$ 
production (Martinson et al., 2010). The morphology of the oil palm stem may harbor hidden 'wetlands' beneath the canopy surface, which could act as sources and/or sinks of trace gases. Oil palm canopy soil is one compartment of the oil palm canopy that has yet to be investigated for its contribution to trace gas fluxes. In oil palms, canopy soil is the organic material lodged between the leaf bases and stem (Fig. 4.1) and is comprised mainly of decomposed organic matter and decomposing leaf bases and epiphytic material. In addition, the leaves at the stem apex of the palm are arranged in sets of spirals. This arrangement allows the intercepted rain by the leaf bases to be high from the top of the stem and decreases as the water is channeled down to the bottom of the stem. Thus, canopy soils at the top of the stem are often wetter than those below.

Canopy soils in tropical forests have been characterized earlier as non-living organic matter intercepted and gathered on branches and are usually comprised predominantly of decomposed epiphytes (Clark et al., 1998), but also of dust, decomposed bark, leaf litter, microorganisms, and invertebrates (Freiberg and Freiberg, 2000; Nadkarni et al., 2002). Canopy soils play an important role in the cycling of nutrients in these ecosystems. In Ecuadorean montane forests, they have been shown to contribute substantially to total soil (canopy soil + ground soil) gross rates of mineral $\mathrm{N}$ production and asymbiotic $\mathrm{N}_{2}$ fixation (Matson et al., 2014, 2015). In Costa Rican lowland forest, canopy soils have higher net $\mathrm{N}$ mineralization, microbial biomass, extractable ammonium $\left(\mathrm{NH}_{4}{ }^{+}\right)$and water contents compared to the forest floor (Cardelús et al., 2009; Wanek et al., 2002).

From the ground soils of tropical ecosystems, it is known that important factors controlling soil $\mathrm{CH}_{4}$ and $\mathrm{N}_{2} \mathrm{O}$ fluxes are soil moisture and $\mathrm{N}$ availability (Davidson et al., 2000; Hassler et al., 2015). For $\mathrm{N}_{2} \mathrm{O}$, which is produced via nitrification and denitrification in soil, the "hole-in-the-pipe" (HIP) model depicts the relationships with $\mathrm{N}$ availability and soil moisture as follows: ground soil $\mathrm{N}_{2} \mathrm{O}$ fluxes are primarily controlled by $\mathrm{N}$ availability (first level of control), and as long as soil $\mathrm{N}$ availability is sufficient soil water content additionally regulates the fluxes (second level of control). Methane production in ground soils is a bi-product of anaerobic decomposition by methanogenic archaea whereas $\mathrm{CH}_{4}$ consumption is a result of $\mathrm{CH}_{4}$ oxidation by methanotrophic bacteria, and hence one of the most important controllers of soil $\mathrm{CH}_{4}$ fluxes is water content (Hassler et al., 2015; Veldkamp et al., 2013). In anaerobic conditions (e.g., high 
soil water content), $\mathrm{CH}_{4}$ production is favored whereas gas diffusivity from the atmosphere into the soil limits $\mathrm{CH}_{4}$ oxidation (Keller and Reiners, 1994; Le Mer and Roger, 2001; Veldkamp et al., 2013). Consequently, since $\mathrm{N}$-cycling rates and water-holding capacity of organic materials composing canopy soils are large (Matson et al., 2014), it is likely that methanogenesis and denitrification are favored. To our knowledge, only one study so far has quantified greenhouse gas fluxes from canopy soils, and this was conducted in tropical montane forests of Ecuador (Matson et al., in press). Although $\mathrm{CH}_{4}$ and $\mathrm{N}_{2} \mathrm{O}$ fluxes from canopy soils of such $\mathrm{N}$-poor montane forests in Ecuador appeared to be very low, these could be different in fertilized and warmer lowland ecosystems. Thus, it is important to quantify these previously unknown fluxes of $\mathrm{CH}_{4}$ and $\mathrm{N}_{2} \mathrm{O}$ from canopy soils of oil palm plantations, especially because the rapid expansion of oil palm plantations may be accompanied with increased canopy soil environments.

Our objectives were to (1) to quantify $\mathrm{N}_{2} \mathrm{O}$ and $\mathrm{CH}_{4}$ fluxes from oil palm canopy soil, and (2) determine their controlling factors. We hypothesized that canopy soil from the uppermost stem section (which will be wetter than the lowermost stem section) will have higher $\mathrm{N}_{2} \mathrm{O}$ and $\mathrm{CH}_{4}$ fluxes than the lowermost stem section, and that mineral $\mathrm{N}$ and moisture content will strongly influence these greenhouse gas fluxes from oil palm canopy soil. Our results provide the first knowledge of greenhouse gas fluxes from oil palm canopy soil, and aid in determining the full extent of greenhouse gas fluxes from this rapidly expanding agricultural cash crop system.

\subsection{Material and methods}

\section{Study area and experimental design}

The study took place in smallholder oil palm plantations located in the lowlands of Jambi Province, Sumatra, Indonesia ( $2^{\circ} 0$ ' 57” S, $103^{\circ} 15$ ' 33” E, 35-95 m above sea level). The mean annual temperature in Jambi is $26.7 \pm 1.0{ }^{\circ} \mathrm{C}$ and the mean annual precipitation is $2235 \pm$ 385 mm (1991-2011; data from a climate station at the Jambi Sultan Thaha airport). In 2013, total rainfall was $3447 \pm 29 \mathrm{~mm}$ (data from climate stations at the villages of Sarolangun and Lubuk Kepayang and from the Harapan Forest Reserve which were approximately 10-20 km from our study sites) and total dissolved $\mathrm{N}$ deposition through rainfall ranged from $12.9 \pm 0.1$ to $16.4 \pm 2.6 \mathrm{~kg} \mathrm{~N} \mathrm{ha}^{-1} \mathrm{yr}^{-1}$ (Kurniawan, 2016). 
Eight smallholder oil palm plantations were selected as replicate sites $(n=8)$, four of which were on clay Acrisol soil and the other four on loam Acrisol soil with about $60 \mathrm{~km}$ distance between each soil type. In each site, we established a plot of $50 \mathrm{~m}$ x $50 \mathrm{~m}$, and the minimum distance between plots within each soil type was $330 \mathrm{~m}$. All plots were on a flat, well-drained area of the landscape. Plantation age ranged from 9 to 16 years and palms were typically established in $9 \mathrm{~m} \times 9 \mathrm{~m}$ grids. Details of soil management practices in these smallholder plantations are described by Allen et al. (2015) and Hassler et al. (2015). In summary, oil palm plantations represented typical smallholder-managed land uses with varied fertilization rates between $48-88 \mathrm{~kg} \mathrm{~N}^{-1} \mathrm{yr}^{-1}$ (except two smallholders who applied $138 \mathrm{~kg} \mathrm{~N}$ $\mathrm{ha}^{-1} \mathrm{yr}^{-1}$ ), 21-38 $\mathrm{kg} \mathrm{P} \mathrm{ha}^{-1} \mathrm{yr}^{-1}$ and 40-157 $\mathrm{kg} \mathrm{K} \mathrm{ha}^{-1} \mathrm{yr}^{-1}$ with the lower range in the clay Acrisol and the upper range in the loam Acrisol. Occasional liming (one small holder applied $200 \mathrm{~kg}$ dolomite $\mathrm{ha}^{-1} \mathrm{yr}^{-1}$ ), and weeding (manually and using herbicides) were conducted, and all management techniques were applied depended on the land owners' availability of funds.

\section{Canopy soil sampling}

Measurements of greenhouse gas fluxes and their controlling factors from canopy soil were conducted from February 2013 to May 2014. Measurements were rotated among the eight plots with bi-weekly to monthly intervals, such that each plot was measured twice during the sampling period, except for one plot, which was measured three times. Thus, in total we conducted 17 measurement periods. Within each $50 \mathrm{~m}$ x $50 \mathrm{~m}$ plot, five palms were selected randomly to represent each plot. A different set of five palms per plot was selected during each measurement period because the canopy soils of selected palms were almost fully removed during every measurement. Sampled palms were 3-3.5 m high and were approximately $18 \mathrm{~m}$ apart within each plot. For canopy soil sampling, the palm stem was divided into three sections to represent possible gradients of mineral $\mathrm{N}$ and water content (as controlling factors of greenhouse gas fluxes) along the stem. The three 1-m stem height sections are: A - spanning from the bottom of the stem up to $1 \mathrm{~m}, \mathrm{~B}$ - centered between sections $\mathrm{A}$ and $\mathrm{C}$, and $\mathrm{C}$ - covering from the lowest palm fronds at the stem apex to $1 \mathrm{~m}$ below (Fig. 4.1). Canopy soil was collected from the leaf bases within these sections, using a long stainless steel spoon, and was mostly comprised of 
decomposed organic matter and decomposing leaf bases and epiphytic materials. Samples from each stem height section per palm were composited, and any undecomposed woody materials, living roots, invertebrates, and green leaves were removed, as these components are not defined as parts of canopy soil (e.g., Clark et al., 1998). Directly after the canopy soils were collected, a subsample of each composited canopy soil per stem section was used for measuring greenhouse gas fluxes using in-situ incubation (see next section) and subsequent determination of gravimetric moisture. Another subsample was used for determination of soil nitrate $\left(\mathrm{NO}_{3}{ }^{-}\right)$, $\mathrm{NH}_{4}{ }^{+}$, and extractable organic $\mathrm{C}$ contents (see section after next).

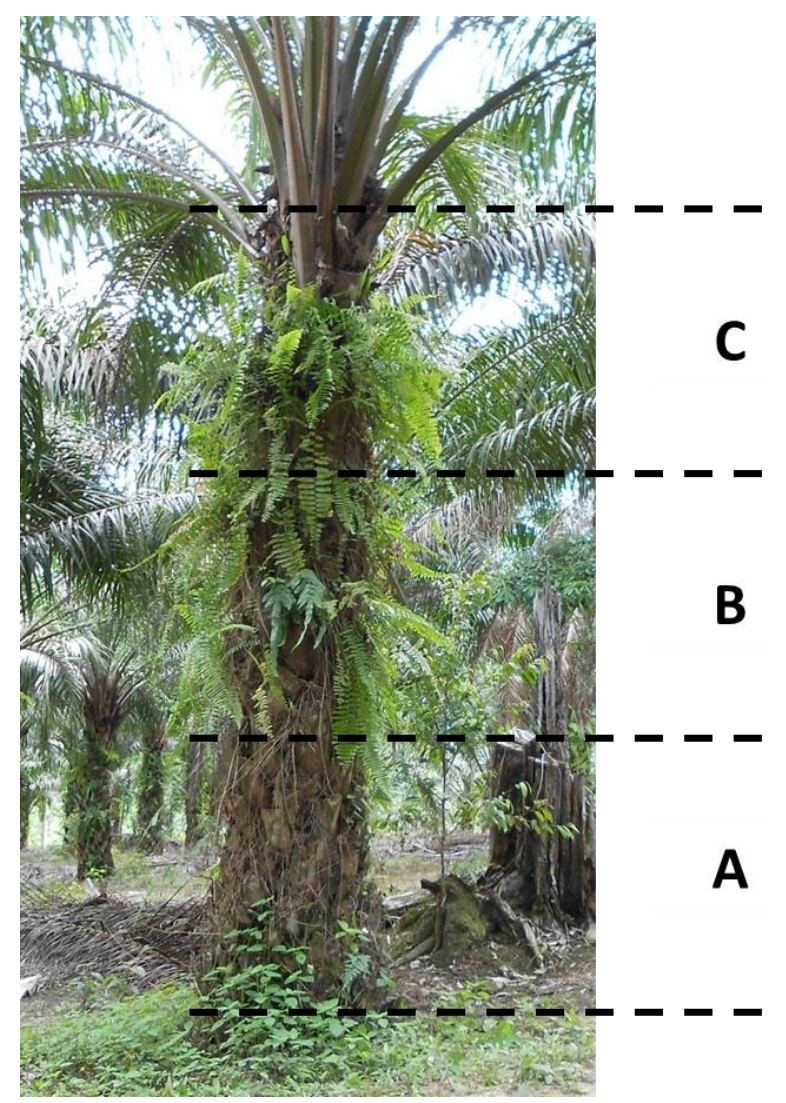

Figure 4.1. Sampling scheme of oil palm stem for measurements of $\mathrm{N}_{2} \mathrm{O}$ and $\mathrm{CH}_{4}$ fluxes from canopy soil (i.e., soil that is lodged between the leaf bases and stem) and for determination of the amount of canopy soil per stem. A - covers from the stem base to 1-m height; B - is a 1-m section between A and C; C covers from the lowest palm fronds at the stem apex down to $1 \mathrm{~m}$. 


\section{Canopy soil incubation and $\mathrm{N}_{2} \mathrm{O}$ and $\mathrm{CH}_{4}$ flux measurement}

Due to the novelty of this study, no one method for measuring greenhouse gas fluxes from oil palm canopy soil has yet been reported in the literature. Therefore, we employed an adaptation of the in-situ incubation method used by Matson et al. (in press). Upon sampling, the canopy soil was immediately placed in $1.1 \mathrm{~L}$ air-tight glass jars. Approximately one-third of a glass jar was filled with freshly sampled canopy soil. The glass jars were covered with aluminum lids fitted with a gas sampling port, after wrapping the rim with parafilm $\mathrm{M}^{\circledR}$ (Bemis Company Inc., Neenah, USA) to ensure sealing (tested previously by Keuter et al., 2014). Three $20 \mathrm{ml}$ gas samples were removed at 20,40, and 60 minutes after jar closure by inserting a syringe with a stainless steel needle into the septa. Gas samples were stored immediately into pre-evacuated $12 \mathrm{ml}$ Labco Exetainers ${ }^{\circledR}$ (Labco Limited, Lampeter, UK), keeping an overpressure. These exetainers have been previously tested by our group to be leak proof during extended periods of storage (e.g., up to 6 months) (Hassler et al., 2015). Within 3-4 months these gas samples were transported by airfreight to the Soil Science of Tropical and Subtropical Ecosystems laboratory (SSTSE) at Georg-August Universität in Göttingen, Germany and analyzed upon arrival, using a gas chromatograph (GC 6000 Vega Series 2, Carlo Erba Instruments, Milan, Italy with an ASPEC autosampler, Gilson SAS, Villiers, Le Bel, France) with a flame ionization detector and an electron capture detector. Three standard gases were used for calibration with concentrations of 360, 1000, and $1600 \mathrm{ppb} \mathrm{N}_{2} \mathrm{O}$ and 1000, 3000, and $5000 \mathrm{ppb} \mathrm{CH}_{4}$ (Deuste Steininger $\mathrm{GmbH}$,

Mühlhausen, Germany). Canopy soil greenhouse gas fluxes were calculated from the linear increase of $\mathrm{N}_{2} \mathrm{O}$ and $\mathrm{CH}_{4}$ over an 1-h incubation period, corrected with air temperature and pressure measured during the measurement period and expressed as per unit of dry canopy soil mass (see next section).

\section{Canopy soil moisture, extractable mineral $N$ and organic $C$, and mineral $N$ production}

Soil moisture, extractable mineral $\mathrm{N}$, and extractable organic $\mathrm{C}$ content were measured parallel to gas sampling. While soil moisture was determined for all 17 measurement periods in the eight sites, extractable mineral $\mathrm{N}$ and organic $\mathrm{C}$ determinations were limited to 13 measurement periods in seven sites. Upon arrival at the field laboratory, about $2 \mathrm{~h}$ following the in-situ 
greenhouse gas flux measurement, non-incubated subsamples of canopy soil were extracted for mineral $\mathrm{N}$ and organic $\mathrm{C}$ with $0.5 \mathrm{~mol} \mathrm{~L}^{-1} \mathrm{~K}_{2} \mathrm{SO}_{4}$. At the same time, the incubated canopy soil was dried at $105^{\circ} \mathrm{C}$ for at least two days to measure gravimetric moisture content. The canopy soils were extracted by shaking for one hour, filtered through pre-washed (with $0.5 \mathrm{~mol} \mathrm{~L}^{-1}$ $\mathrm{K}_{2} \mathrm{SO}_{4}$ ) filter papers ( $4 \mu \mathrm{m}$ nominal pore size), and extracts were frozen immediately. The frozen extracts were transported by airfreight to SSTSE for analysis of $\mathrm{NH}_{4}{ }^{+}$and $\mathrm{NO}_{3}{ }^{-}$, using continuous flow injection colorimetry (SEAL Analytical AA3, SEAL Analytical GmbH, Norderstedt, Germany). Ammonium was determined by salicylate and dicloro-isocyanuric acid reaction (Autoanalyzer Method G-102-93), and $\mathrm{NO}_{3}{ }^{-}$by cadmium reduction method with $\mathrm{NH}_{4} \mathrm{Cl}$ buffer (Autoanalyzer Method G-254-02). Organic C concentrations in the extracts were also analyzed using UV-enhanced persulfate oxidation in a Total Organic Carbon Analyzer (TOC-Vwp, Shimadzu Europa GmbH, Duisburg, Germany) with an infrared detector.

To determine gross rates of mineral $\mathrm{N}$ production of oil palm canopy soil (as an index of soil $\mathrm{N}$ availability; Matson et al., 2014), two palms were chosen in one smallholder oil palm plantation. Each palm was sampled at the three stem sections (i.e., A, B, C) and gross rates of mineral $\mathrm{N}$ production (i.e., gross $\mathrm{N}$ mineralization and gross nitrification) and microbial biomass $\mathrm{C}$ and $\mathrm{N}$ were measured using the ${ }^{15} \mathrm{~N}$ pool dilution technique (Davidson et al., 1991) and the chloroform fumigation-extraction method, respectively (Brookes et al., 1985; Davidson et al., 1989). We have described the details of these measurements in our earlier work on gross rates of soil-N cycling from the same study sites using intact cores from the ground soils (Allen et al., 2015), with the main difference that here we used a composited canopy soil. In short, a composite canopy soil sample was made from each stem section, separated into four subsamples (average dry mass of $6 \mathrm{~g}$ each) and placed into plastic bags. In the field, two of the canopy soil subsamples were injected with $5 \mathrm{~mL}$ of ${ }^{15} \mathrm{NH}_{4} \mathrm{SO}_{4}$ (95\% enriched) solution and the other two with $5 \mathrm{~mL}$ of $\mathrm{K}^{15} \mathrm{NO}_{3}$ (95\% enriched) solution. Both solutions contained $30 \mathrm{mg} \mathrm{N} \mathrm{L}^{-1}$. One of each pair of canopy soil subsamples (i.e., one ${ }^{15} \mathrm{NH}_{4} \mathrm{SO}_{4}$-injected and one $\mathrm{K}^{15} \mathrm{NO}_{3}$-injected) was extracted immediately using $0.5 \mathrm{~mol} \mathrm{~L}^{-1} \mathrm{~K}_{2} \mathrm{SO}_{4}$. The other pair of subsamples was incubated insitu for 24 hours and then extracted with $0.5 \mathrm{~mol} \mathrm{~L}^{-1} \mathrm{~K}_{2} \mathrm{SO}_{4}$. Extractions and mineral $\mathrm{N}$ analysis followed the same methods as described above. Microbial biomass $\mathrm{C}$ and $\mathrm{N}$ were determined from canopy soil subsamples (average dry mass of $5 \mathrm{~g}$ each) by chloroform fumigation for six days, and then extracted with $0.5 \mathrm{~mol} \mathrm{~L}^{-1} \mathrm{~K}_{2} \mathrm{SO}_{4}$, analyzed for organic $\mathrm{C}$ and $\mathrm{N}$, and calculated to 
microbial $\mathrm{C}$ and $\mathrm{N}$ using the background organic $\mathrm{C}$ and $\mathrm{N}$ from unfumigated subsamples, as described in our earlier work (Allen et al., 2015).

\section{Canopy soil biomass determination}

To our knowledge, there is no previous determination of canopy soil biomass in oil palm. Therefore, in order to scale-up our greenhouse gas flux measurements, we determined canopy soil biomass on three felled oil palms, which we were allowed for destructive sampling. Each palm was between 2-4.4 m high and was initially cut at approximately $0.4 \mathrm{~m}$ above the ground. After felling, the palm was further cut into 1-m sections according to our stem sections for canopy soil $\mathrm{N}_{2} \mathrm{O}$ and $\mathrm{CH}_{4}$ flux measurement. Leaf bases from each stem section were stripped, and canopy soil was collected and weighed. Canopy soil from the stump was also collected and added to the lowermost stem section (section A). A portion of the canopy soil per stem section was dried for two days at $105{ }^{\circ} \mathrm{C}$ to determine gravimetric moisture content. We then used this measured gravimetric moisture content to calculate the dry mass of canopy soil from the fresh mass per stem section. The average dry mass of canopy soil per stem section was taken from the measured three palms; any unmeasured canopy soil mass not within the three 1-m sections was estimated by extrapolations of dry soil mass from the measured sections A, B, and C. Using the plant density in our smallholder plantations ( 137 trees $^{-1}{ }^{-1}$; Kotowska et al., 2015), we calculated the total amount of canopy soil per stem section in a hectare. The mean (averaged across the measurement period for each site) greenhouse gas flux per dry soil mass for each stem section was multiplied with the total dry mass soil per hectare, and summed for the three stem sections to come up with the total greenhouse gas flux per hectare.

\section{Statistical analysis}

To answer our first objective, we compared the canopy soil greenhouse gas fluxes and their potential controlling factors among the three stem sections. The plots were our real replicates whereas the five randomly selected palms per plot were subsamples to represent each plot. Thus, comparisons among the three stem sections were conducted using the means of the five palms per plot per stem section. First, each parameter was tested for normal distribution (using Shapiro- 
Wilk's test) and equality of variance (using Levene's test), and parameters with non-normal distributions or unequal variances were either logarithmically (for $\mathrm{N}_{2} \mathrm{O}, \mathrm{NH}_{4}{ }^{+}$, and organic C) or square-root transformed (for $\mathrm{NO}_{3}{ }^{-}$). We used linear mixed effects (LME) models wherein stem section was considered a fixed effect and site and measurement day were random effects. The fixed effect was considered statistically significant at $P \leq 0.05$ based on the analysis of variance, and differences among stem sections were assessed using the Tukey HSD test at $P \leq 0.05$. For our second objective, we applied Pearson's correlation tests using the means of the five palms per plot per stem section to assess the relationships of canopy soil $\mathrm{N}_{2} \mathrm{O}$ and $\mathrm{CH}_{4}$ fluxes with moisture, mineral $\mathrm{N}$, and extractable organic $\mathrm{C}$ contents across stem sections and sampling days. Correlations were considered statistically significant at $P \leq 0.05$ and marginally significant at $P$ $\leq$ 0.09. All statistical analyses were conducted using R 3.2.2 (R Development Core Team, 2015).

\subsection{Results}

Canopy soils from all stem sections of the oil palms emitted $\mathrm{N}_{2} \mathrm{O}$ and $\mathrm{CH}_{4}$ (Table 4.1). The topmost stem section (C) displayed four times higher canopy soil $\mathrm{N}_{2} \mathrm{O}$ fluxes compared to the lower stem sections (A and B) $\left(P \leq 0.01\right.$; Table 4.1). Canopy soil $\mathrm{CH}_{4}$ fluxes were 2.5 times higher at stem section $\mathrm{C}$ compared to stem section $\mathrm{A}$ and were intermediary at the mid-stem section $\mathrm{B}(P=0.01$; Table 4.1). Moisture content was also highest at stem section $\mathrm{C}$ and decreased at the lower stem sections $(P \leq 0.01$; Table 4.1). Ammonium content was higher at

Table 4.1. Mean ( $\pm \mathrm{SE}$ ) canopy soil $\mathrm{N}_{2} \mathrm{O}$ and $\mathrm{CH}_{4}$ fluxes, canopy soil moisture content (all $\left.n=8\right)$, canopy soil-extractable mineral $\mathrm{N}$, and organic carbon (all $n=7$ ) from three stem sections (A-bottom, B-middle, C-top), measured in smallholder oil palm plantations in Jambi, Sumatra, Indonesia. Means followed by different letters indicate significant differences among stem sections (linear mixed effects model with Tukey HSD test at $P \leq 0.05$ ).

\begin{tabular}{lllllll}
\hline Height & $\begin{array}{l}\mathrm{N}_{2} \mathrm{O} \mathrm{fluxes} \\
\left(\mu \mathrm{g} \mathrm{kg} \mathrm{k}^{-1} \mathrm{~h}^{-1}\right)\end{array}$ & $\begin{array}{l}\mathrm{CH}_{4} \text { fluxes } \\
\left(\mu \mathrm{C} \mathrm{kg}^{-1} \mathrm{~h}^{-1}\right)\end{array}$ & $\begin{array}{l}\text { Moisture } \\
\text { content } \\
\left(\mathrm{g} \mathrm{H}_{2} \mathrm{O} \mathrm{g}^{-1}\right)\end{array}$ & $\begin{array}{l}\mathrm{NH}_{4}^{+} \\
\left(\mathrm{mg} \mathrm{N} \mathrm{kg}^{-1}\right)\end{array}$ & $\begin{array}{l}\mathrm{NO}_{3}^{-} \\
\left(\mathrm{mg} \mathrm{N} \mathrm{kg}^{-1}\right)\end{array}$ & $\begin{array}{l}\text { Extractable } \\
\text { organic C } \\
\left(\mathrm{g} \mathrm{C} \mathrm{kg}^{-1}\right)\end{array}$ \\
\hline $\mathrm{A}$ & $3.55 \pm 0.90^{\mathrm{b}}$ & $0.67 \pm 0.11^{\mathrm{b}}$ & $1.47 \pm 0.23^{\mathrm{c}}$ & $95.14 \pm 14.72^{\mathrm{ab}}$ & $55.27 \pm 11.02^{\mathrm{b}}$ & $1.45 \pm 0.15^{\mathrm{b}}$ \\
$\mathrm{B}$ & $3.93 \pm 1.17^{\mathrm{b}}$ & $1.44 \pm 0.50^{\mathrm{ab}}$ & $1.97 \pm 0.26^{\mathrm{b}}$ & $120.13 \pm 19.34^{\mathrm{a}}$ & $49.26 \pm 9.70^{\mathrm{b}}$ & $2.11 \pm 0.22^{\mathrm{a}}$ \\
$\mathrm{C}$ & $14.96 \pm 5.78^{\mathrm{a}}$ & $1.64 \pm 0.48^{\mathrm{a}}$ & $3.14 \pm 0.23^{\mathrm{a}}$ & $70.56 \pm 8.87^{\mathrm{b}}$ & $91.62 \pm 13.49^{\mathrm{a}}$ & $1.08 \pm 0.12^{\mathrm{c}}$ \\
\hline
\end{tabular}


stem section $\mathrm{B}$ compared to stem section $\mathrm{C}$ and was intermediary at stem section $\mathrm{A}$, and $\mathrm{NO}_{3}{ }^{-}$ content was highest at stem section C compared to the lower stem sections (A and B) (both $P \leq 0.01$; Table 4.1). Extractable organic $\mathrm{C}$ content was highest at stem section $\mathrm{B}$, followed by stem section $\mathrm{A}$, and lowest at stem section $\mathrm{C}(P \leq 0.01$; Table 4.1). Gross rates of mineral $\mathrm{N}$ production and microbial biomass in canopy soils were highest at stem section $\mathrm{C}$ (Table 4.2). Using the estimated amounts of dry mass of canopy soils per stem section $\left(52,65\right.$, and $52 \mathrm{~kg} \mathrm{ha}^{-1}$ at $\mathrm{A}, \mathrm{B}$, and $\mathrm{C}$ sections, respectively) and the canopy soil $\mathrm{N}_{2} \mathrm{O}$ and $\mathrm{CH}_{4}$ fluxes per stem section (Table 4.1), annual canopy soil fluxes were $10.7 \pm 3.3 \mathrm{~g} \mathrm{~N}_{2} \mathrm{O}-\mathrm{N} \mathrm{ha}^{-1} \mathrm{yr}^{-1}$ and $1.9 \pm 0.5 \mathrm{~g} \mathrm{CH}_{4}-\mathrm{C}$ $\mathrm{ha}^{-1} \mathrm{yr}^{-1}$.

Table 4.2. Gross rates of mineral $\mathrm{N}$ production and microbial biomass (mean of two palms) in canopy soil from three stem sections (A-bottom, B-middle, C-top) in a smallholder oil palm plantation in Jambi, Sumatra, Indonesia.

\begin{tabular}{lllll}
\hline Height & $\begin{array}{l}\text { Gross N mineralization } \\
\left(\mathrm{mg} \mathrm{N} \mathrm{kg}^{-1} \mathrm{day}^{-1}\right)\end{array}$ & $\begin{array}{l}\text { Gross nitrification } \\
\left(\mathrm{mg} \mathrm{N} \mathrm{kg}^{-1} \mathrm{day}^{-1}\right)\end{array}$ & $\begin{array}{l}\text { Microbial N } \\
\left(\mathrm{mg} \mathrm{N} \mathrm{kg}^{-1}\right)\end{array}$ & $\begin{array}{l}\text { Microbial C } \\
\left(\mathrm{g} \mathrm{C} \mathrm{kg}^{-1}\right)\end{array}$ \\
\hline A & 78.0 & 13.6 & 375.9 & 4.0 \\
B & 22.5 & 18.4 & 553.3 & 4.5 \\
C & 126.8 & 316.5 & 1178.2 & 8.7 \\
\hline
\end{tabular}

Considering all stem sections, plots, and sampling days, canopy soil $\mathrm{CH}_{4}$ fluxes correlated positively with moisture content $(R=0.24, P=0.09, n=50$; Fig. 4.2a) and canopy soil $\mathrm{N}_{2} \mathrm{O}$ fluxes correlated positively with moisture $(R=0.53, P \leq 0.01, n=50$; Fig. 4.2b) and $\mathrm{NO}_{3}{ }^{-}$contents $\left(R=0.30, P=0.07, n=38\right.$; Fig. 4.2d) and negatively with $\mathrm{NH}_{4}{ }^{+}$content ( $R=-0.31, P=0.06, n=38$; Fig. 4.2c). Other than these, there were no other significant correlations detected. 
a)

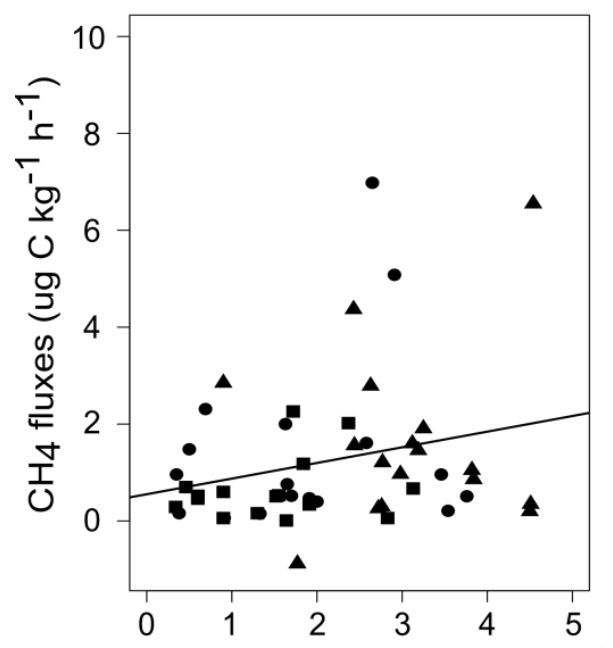

Moisture content ( $\mathrm{g} \mathrm{H}_{2} \mathrm{O} \mathrm{g} \mathrm{soil}^{-1}$ )

c)

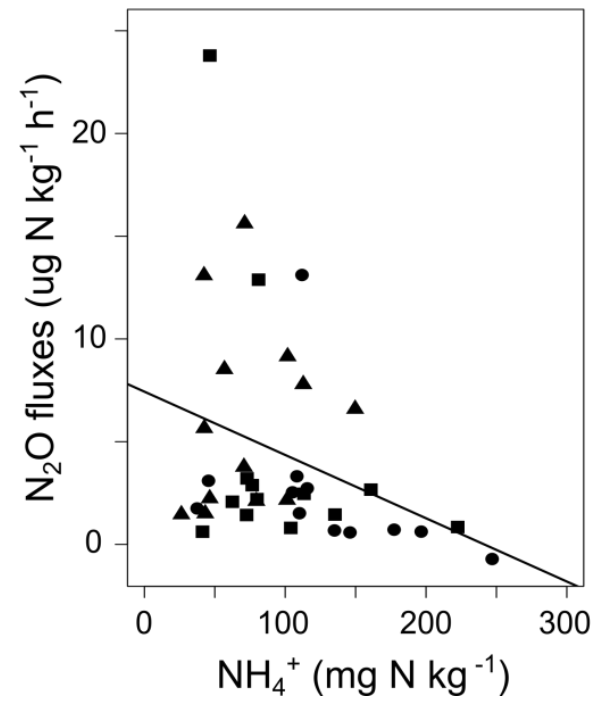

b)

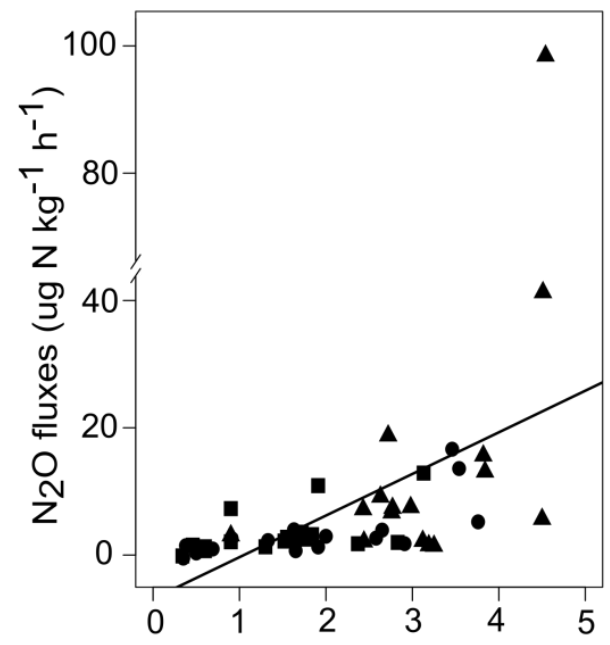

Moisture content ( $\mathrm{g} \mathrm{H}_{2} \mathrm{O} \mathrm{g} \mathrm{soil}^{-1}$ )

d)

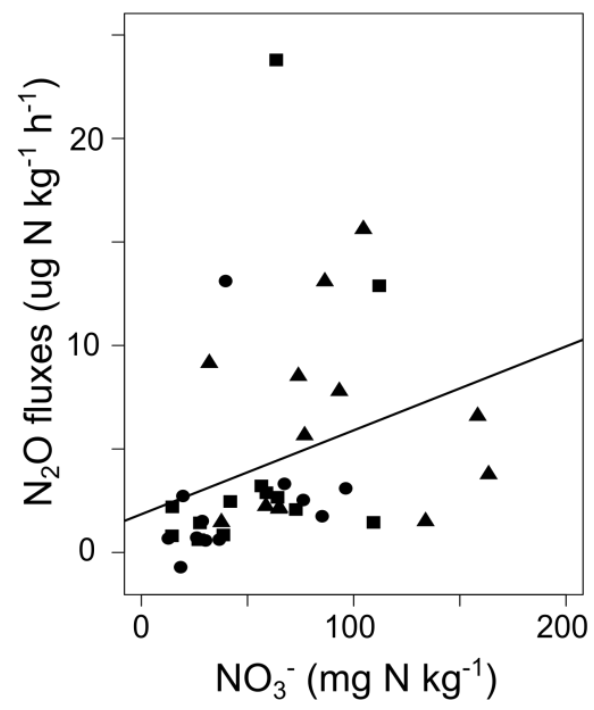

Figure 4.2. Relationships of canopy soil $\mathrm{CH}_{4}$ fluxes with moisture content $(R=0.24, P=0.09, n=50)$ (a), and canopy soil $\mathrm{N}_{2} \mathrm{O}$ fluxes with moisture $(R=0.53, P<0.01, n=50)(\mathbf{b}), \mathrm{NH}_{4}{ }^{+}(R=-0.31, P=0.06$, $n=38)$ (c) and $\mathrm{NO}_{3}{ }^{-}$contents $(R=0.30, P=0.07, n=38)(\mathbf{d})$ across three stem sections (A-bottom ( $\square$ ), B-

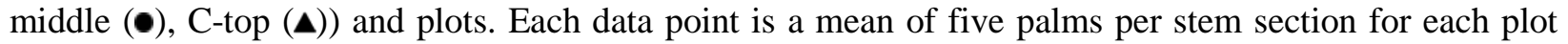
and measurement period.

\subsection{Discussion}

\section{Oil palm canopy soil $\mathrm{N}_{2} \mathrm{O}$ and $\mathrm{CH}_{4}$ fluxes}

From the few studies that exist on biogeochemical processes in canopy soils, it is evident that these components contribute to the overall nutrient cycling in forest ecosystems (Cardelús et al., 
2009; Matson et al., 2014, 2015; Nadkarni et al., 2004). However, greenhouse gas fluxes and N cycling in canopy soils of systems other than natural ecosystems, such as those in managed oil palm plantations, to our knowledge has never been documented in the literature. Thus, we can only compare our measurements with one study so far that has measured greenhouse gas fluxes from canopy soils of tropical montane forests in Ecuador (Matson et al., in press). Our measured oil palm canopy soil $\mathrm{N}_{2} \mathrm{O}$ and $\mathrm{CH}_{4}$ fluxes were higher than those measured from canopy soils in Ecuadorian montane forests $\left(-0.37-0.98 \mu \mathrm{g} \mathrm{N} 2 \mathrm{O}-\mathrm{N} \mathrm{kg}^{-1} \mathrm{~h}^{-1}\right.$ and $-1.32-0.38 \mu \mathrm{g} \mathrm{CH} \mathrm{CH} \mathrm{kg}^{-1} \mathrm{~h}^{-1}$; Matson et al., in press). However, our estimated canopy soil $\mathrm{N}_{2} \mathrm{O}$ and $\mathrm{CH}_{4}$ fluxes on a hectare basis (see Sect. 4.3) were small because the amount of canopy soil in our oil palm plantations was smaller compared to the estimated canopy soils in Ecuadorian montane forest (3877 kg ha ${ }^{-1}$; Werner et al., 2012) and Costa Rican lower montane forest (21 Mg ha ${ }^{-1}$; Nadkarni et al., 2004). Also, our measured net $\mathrm{CH}_{4}$ emissions from the oil palm canopy soils on a hectare basis were much lower than the net $\mathrm{CH}_{4}$ emission of $1 \mathrm{~kg} \mathrm{CH}_{4}-\mathrm{C} \mathrm{ha}^{-1} \mathrm{yr}^{-1}$ from tank bromeliads of Ecuadorian montane forests (Martinson et al., 2010).

Comparing our measurements to the ground soil greenhouse gas fluxes from the same smallholder oil palm plantations with $1.1 \pm 0.3 \mathrm{~kg} \mathrm{~N}_{2} \mathrm{O}-\mathrm{N} \mathrm{ha}^{-1} \mathrm{yr}^{-1}$ (Hassler et al., 2016) and $-1.0 \pm 0.3 \mathrm{~kg} \mathrm{CH}_{4}-\mathrm{C} \mathrm{ha}^{-1} \mathrm{yr}^{-1}$ (Hassler et al., 2015), canopy soil $\mathrm{N}_{2} \mathrm{O}$ fluxes contributed only $1 \%$ of the total soil (canopy soil + ground soil) $\mathrm{N}_{2} \mathrm{O}$ fluxes and canopy soil net $\mathrm{CH}_{4}$ emission was only $0.2 \%$ of the ground soil net $\mathrm{CH}_{4}$ consumption. We attributed the relatively low $\mathrm{CH}_{4}$ emissions from these oil palm canopy soils, despite their high moisture content, to their high $\mathrm{NO}_{3}{ }^{-}$content (Table 4.1). Nitrate has higher redox potential than other succeeding electron acceptors, and when denitrification is prevalent (which was possibly the case in our canopy soils as implied by the positive correlations of $\mathrm{N}_{2} \mathrm{O}$ fluxes with moisture and $\mathrm{NO}_{3}{ }^{-}$content) methanogenic activity is minimal (Bollag and Czlonkowski, 1973). Also, $\mathrm{NO}_{3}{ }^{-}$reducers are more competitive than methanogens for electron donors (Klüber and Conrad, 1998a), and denitrification intermediates (nitrite, $\mathrm{NO}, \mathrm{N}_{2} \mathrm{O}$ ) appear to inhibit methanogenesis (Klüber and Conrad, 1998b; Roy and Conrad, 1999). Taking into account both the ground and canopy soils, the latter's contribution to the total soil $\mathrm{N}_{2} \mathrm{O}$ flux on a hectare basis was negligible and the soil as a whole still served as a net sink for $\mathrm{CH}_{4}$. 


\section{Factors controlling oil palm canopy soil $\mathrm{N}_{2} \mathrm{O}$ and $\mathrm{CH}_{4}$ fluxes}

Variation in soil $\mathrm{N}$ availability along stem height led to differences in canopy soil $\mathrm{N}_{2} \mathrm{O}$ fluxes among stem sections, with the highest $\mathrm{N}$ availability and $\mathrm{N}_{2} \mathrm{O}$ fluxes at the top stem section. This control of $\mathrm{N}$ availability on $\mathrm{N}_{2} \mathrm{O}$ fluxes (depicted as the first level of control in the HIP model; Davidson et al., 2000) in canopy soils was indicated by the large gross rates of mineral $\mathrm{N}$ production, microbial biomass as well as $\mathrm{NO}_{3}{ }^{-}$content at the top stem section (Tables 4.1 and 4.2), and was supported by the positive correlation between canopy soil $\mathrm{N}_{2} \mathrm{O}$ fluxes and $\mathrm{NO}_{3}{ }^{-}$ content (Fig. 4.2d). The negative correlation between canopy soil $\mathrm{N}_{2} \mathrm{O}$ fluxes and $\mathrm{NH}_{4}{ }^{+}$content suggests a similar influence of $\mathrm{N}$ availability since $\mathrm{NH}_{4}{ }^{+}$and $\mathrm{NO}_{3}{ }^{-}$contents showed opposite patterns (Table 4.1, Fig. 4.2c, d). Our findings were also consistent with those from forest canopy soils in Ecuador, where $\mathrm{N}$ addition to the forest floor increased canopy soil $\mathrm{N}_{2} \mathrm{O}$ fluxes, suggesting the dependence of canopy soil $\mathrm{N}_{2} \mathrm{O}$ fluxes on $\mathrm{N}$ availability in an ecosystem (Matson et al., in press).

The variation in soil moisture content along stem height additionally explained the differences in canopy soil greenhouse gas fluxes among stem sections (Table 4.1). The highest $\mathrm{N}_{2} \mathrm{O}$ and $\mathrm{CH}_{4}$ fluxes were found at the top stem section, which also displayed the highest moisture content (Table 4.1). Leaf axils at the top of the stem were younger and less decomposed than leaf axils lower on the stem, and these top leaf axils were able to store canopy-trapped moisture from rainfall better than the more decomposed leaf axils at the lower parts of the stem. The positive correlations of oil palm canopy soil $\mathrm{N}_{2} \mathrm{O}$ and $\mathrm{CH}_{4}$ fluxes with water content (Fig. $4.2 \mathrm{a}, \mathrm{b}$ ) indicated the control of water content on soil $\mathrm{N}_{2} \mathrm{O}$ (depicted as the second level of control in the HIP model; Davidson et al., 2000) and $\mathrm{CH}_{4}$ fluxes (Martinson et al., 2010; Veldkamp et al., 2013). Our results demonstrate that the two important soil factors, $\mathrm{N}$ availability and water content, which are known to regulate ground soil greenhouse gas fluxes were also the main factors influencing greenhouse gas fluxes from oil palm canopy soils.

\subsection{Relevance of canopy soil $\mathrm{N}_{2} \mathrm{O}$ and $\mathrm{CH}_{4}$ fluxes}

Our study illustrates that oil palm canopy soil can be a source of $\mathrm{N}_{2} \mathrm{O}$ and $\mathrm{CH}_{4}$, and that fluxes differed with stem height because of differences in $\mathrm{N}$ availability and moisture content. The 
contribution of oil palm canopy soil greenhouse gas fluxes to total soil fluxes (canopy soil + ground soil) on a hectare basis were low, but considering the increasing areal coverage of oil palm plantations in Jambi Province, Indonesia (721000; BPS, 2014) our extrapolated estimate of canopy soil greenhouse gas emissions from oil palm in this province were $7.7 \mathrm{Mg} \mathrm{N}_{2} \mathrm{O}-\mathrm{N} \mathrm{yr}^{-1}$ and $1.3 \mathrm{Mg} \mathrm{CH}_{4}-\mathrm{C} \mathrm{yr}^{-1}$. In addition, the Indonesian government plans to double the land area under oil palm plantations by 2020 (Carlson et al., 2013), which could increase the contribution of oil palm canopy soils to greenhouse gas emissions. However, it is also important to note, that throughout the life-cycle of an oil palm plantation, the oil palm canopy soil environment would also evolve. The results we report here (from first generation plantations of 9-16 years old), reflect the years with probably high canopy soil accumulation, and hence possibly also high levels of greenhouse gas fluxes. On one hand, younger oil palm plantations have not had time to accumulate canopy soil. On the other hand, as an oil palm ages its leaf axils fall off (only 20\% of the fronds remain attached to the stem 25 years after planting; Henson et al., 2012) and thus the stem area for canopy soil accumulation could be reduced and so would greenhouse gas emissions. Oil palm plantations, particularly those from large-scale plantations (comprising $38 \%$ of oil palm land area in Jambi Province; BPS, 2014) are exposed to large fertilizer inputs (typically 130-260 kg N ha ${ }^{-1} \mathrm{yr}^{-1}$ in Jambi Province; Pahan, 2010) which could easily be 2-4 times higher than the rates in our studied smallholder plantations. It has been shown that nutrient addition may affect nutrient cycling and greenhouse gas emissions in forest canopy soils (Matson et al., 2014, 2015, in press). Therefore, to improve our estimate of oil palm canopy soil's contribution to greenhouse gas emissions, investigations should focus on chronosequence of oil palm plantations and gradients of agricultural management practices to cover differences in fertilization rates.

Acknowledgements. This study was funded by the Deutsche Forschungsgemeinschaft (DFG) as part of the project A05 (SFB 990/2) in the framework of the German-Indonesian Collaborative Research Center 990: Ecological and Socioeconomic Functions of Tropical Lowland Rainforest Transformation Systems. S. Kurniawan received a post-graduate scholarship from the Indonesian Directorate General of Higher Education. We thank the village leaders, local plot owners, and PT Humusindo for granting us access and use of their properties. We gratefully acknowledge our 
Indonesian assistants: Edward Januarlin Siahaan, Nelson Apriadi Silalahi, Ardi, Fahrurrozy Borland, Khairul Anwar, and Edi. We acknowledge project A03 and the Indonesian Meteorological, Climatological, and Geophysical Agency for climatic data and we thank Norman Loftfield, Andrea Bauer, Kerstin Langs, and Martina Knaust (Georg-August University Göttingen, Germany) for their assistance with laboratory analyses. This study was conducted using the research permits (210/SIP/FRP/SM/VI/2012 and 45/EXT/SIP/FRP/SM/V/2013) from the Ministry of Research and Technology of Indonesia (RISTEK), and the collection permits (2703/IPH.1/KS.02/XI/2012 and S.13/KKH-2/2013) from the Indonesian Institute of Sciences (LIPI) and the Ministry of Forestry (PHKA). 


\section{References}

Allen, K., Corre, M. D., Tjoa, A., and, Veldkamp, E.: Soil nitrogen-cycling responses to conversion of lowland forests to oil palm and rubber plantations in Sumatra, Indonesia, PLoS ONE, 10, e0133325, 2015.

Bollag, J. M. and Czlonkowski, S. T.: Inhibition of methane formation in soil by various nitrogen-containing compounds, Soil Biol. Biochem., 5, 673-678, 1973.

BPS (Badan Pusat Statistik): Indonesian oil palm statistics 2013, BPS, Jakarta, Indonesia, 2014.

Brookes, P. C., Landman, A., Pruden, G., and Jenkinson, D. S.: Chloroform fumigation and the release of soil nitrogen: a rapid direct extraction method to measure microbial biomass nitrogen in soil, Soil Biol. Biochem., 17, 837-842, 1985.

Cardelús, C. L., Mack, M. C., Woods, C., DeMarco, J., and Treseder, K. K.: The influence of tree species on canopy soil nutrient status in a tropical lowland wet forest in Costa Rica, Plant Soil, 318, 47-61, 2009.

Carlson, K. M., Curran, L. M., Asner, G. P., Pittman, A. M., Trigg, S. N., and Adeney, J. M.: Carbon emissions from forest conversion by Kalimantan oil palm plantations, Nature Climate Change, 3, 283-287, 2013.

Clark, K. L., Nadkarni, N. M., and Gholz, H. L.: Growth, net production, litter decomposition, and net nitrogen accumulation by epiphytic bryophytes in a tropical montane forest, Biotropica, 30, 12-23, 1998.

Clough, Y., Krishna, V. V., Corre, M. D., Darras, K., Denmead, L. H., Meijide, A., Moser, S., Musshoff, O., Steinebach, S., Veldkamp, E., Allen, K., et al.: Land-use choices follow profitability at the expense of ecological functions in Indonesian smallholder landscapes, Nat. Commun., 7, 13137, 2016.

Davidson, E. A., Eckert, R. W., Hart, S. C., and Firestone, M. K.: Direct extraction of microbial biomass nitrogen from forest and grassland soils of California, Soil Biol. Biochem., 21, 773-778, 1989. 
Davidson, E. A., Hart, S. C., Shanks, C. A., and Firestone, M. K.: Measuring gross nitrogen mineralization, immobilization, and nitrification by ${ }^{15} \mathrm{~N}$ isotopic pool dilution in intact soil cores, J. Soil Sci., 42, 335-349, 1991.

Davidson, E. A., Keller, M., Erickson, H. E., Verchot, L. V., and Veldkamp, E.: Testing a conceptual model of soil emissions of nitrous and nitric oxides, Bioscience, 50, 667-680, 2000.

FAO (Food and Agricultural Organization): FAOSTAT database, available at: http://faostat3.fao.org/compare/E (last access 16 October 2016), 2016.

Fowler, D., Nemitz, E., Misztal, P., Di Marco, C., Skiba, U., Ryder, J., Helfter, C., Cape, J. N., Owen, S., Dorsey, J., Gallagher, M. W., et al.: Effects of land use on surface-atmosphere exchanges of trace gases and energy in Borneo: comparing fluxes over oil palm plantations and a rainforest, Philos. T. Roy. Soc. B., 366, 3196-3209, 2011.

Freiberg, M. and Freiberg, E.: Epiphyte diversity and biomass in the canopy of lowland and montane forests in Ecuador, J. Trop. Ecol., 16, 673-688, 2000.

Hassler, E., Corre, M. D., Tjoa, A., Damris, M., Utami, S. R., and Veldkamp, E.: Soil fertility controls soil-atmosphere carbon dioxide and methane fluxes in a tropical landscape converted from lowland forest to rubber and oil palm plantations, Biogeosciences, 12, 5831-5852, 2015.

Hassler, E., Corre, M. D., Kurniawan, S., and Veldkamp, E.: Soil nitrogen oxide fluxes from lowland forests converted to smallholder rubber and oil palm plantations in Sumatra, Indonesia, Biogeosciences Discuss., in review, 2016.

Henson, I. E., Betitis, T., Tomda, Y., and Chase, L. D. C.: The estimation of frond base biomass (FBB) of oil palm, J. Oil Palm Res., 24, 1473-1479, 2012.

Hewitt, C. N., MacKenzie, A. R., Di Carlo, P., Di Marco, C. F., Dorsey, J. R., Evans, M., Fowler, D., Gallagher, M. W., Hopkins, J. R., Jones, C. E., Langford, B., et al.: Nitrogen management is essential to prevent tropical oil palm plantations from causing ground-level ozone pollution, P. Natl. Acad. Sci. USA, 106, 18447-18451, 2009.

Keller, M. and Reiners, W. A.: Soil-atmosphere exchange of nitrous oxide, nitric oxide, and methane under secondary succession of pasture to forest in the Atlantic lowlands of Costa Rica, 
Global Biogeochem. Cy., 8, 399-409, 1994.

Keuter, A., Veldkamp, E., and Corre, M. D.: Asymbiotic biological nitrogen fixation in a temperate grassland as affected by management practices, Soil Biol. Biochem., 70, 38-46, 2014.

Klüber, H. D. and Conrad, R.: Effects of nitrate, nitrite, $\mathrm{NO}$ and $\mathrm{N}_{2} \mathrm{O}$ on methanogenesis and other redox processes in anoxic rice field soil, FEMS Microbiol. Ecol., 25, 301-318, 1998a.

Klüber, H. D. and Conrad, R.: Inhibitory effects of nitrate, nitrite, $\mathrm{NO}$ and $\mathrm{N}_{2} \mathrm{O}$ on methanogenesis by Methanosarcina barkeri and Methanobacterium bryantii, FEMS Microbiol. Ecol., 25, 331-339, 1998b.

Kotowska, M. M., Leuschner, C., Triadiati, T., Meriem, S., and Hertel, D.: Quantifying above and belowground biomass carbon loss with forest conversion in tropical lowlands of Sumatra (Indonesia), Glob. Change Biol., 21, 3620-3634, 2015.

Kurniawan, S.: Conversion of lowland forests to rubber and oil palm plantations changes nutrient leaching and nutrient retention efficiency in highly weathered soils of Sumatra, Indonesia (Doctoral dissertation, Faculty of Forest Sciences and Forest Ecology, Georg-August University of Goettingen), available at: http://hdl.handle.net/11858/00-1735-0000-0028-8706-8 (last access: 25.05.2016), 2016.

Le Mer, J. and Roger, P.: Production, oxidation, emission and consumption of methane by soils: A review, Eur. J. Soil Biol., 37, 25-50, 2001.

MacKenzie, A. R., Langford, B., Pugh, T. A. M., Robinson, N., Misztal, P. K., Heard, D. E., Lee, J. D., Lewis, A. C., Jones, C. E., Hopkins, J. R., Phillips, G., et al.: The atmospheric chemistry of trace gases and particulate matter emitted by different land uses in Borneo, Philos. T. Roy. Soc. B., 366, 3177-3195, 2011.

Margono, B. A., Potapov, P. V., Turubanova, S., Stolle, F., and Hansen, M. C.: Primary forest cover loss in Indonesia over 2000-2012, Nat. Clim. Chang., 4, 730-735, 2014.

Martinson, G. O., Werner, F. A., Scherber, C., Conrad, R., Corre, M. D., Flessa, H., Wolf, K., Klose, M., Gradstein, S. R., and Veldkamp, E.: Methane emissions from tank bromeliads in neotropical forests, Nat. Geosci., 3, 766-769, 2010. 
Matson, A. L., Corre, M. D. and Veldkamp, E.: Nitrogen cycling in canopy soils of tropical montane forests responds rapidly to indirect N and P fertilization, Glob. Change Biol., 20, 38023813, 2014.

Matson, A. L., Corre, M. D., Burneo, J. I., and Veldkamp, E.: Free-living nitrogen fixation responds to elevated nutrient inputs in tropical montane forest floor and canopy soils of southern Ecuador, Biogeochemistry, 122, 281-294, 2015.

Matson, A. L., Corre, M. D., and Veldkamp, E.: Canopy soil greenhouse gas dynamics in response to indirect fertilization across an elevation gradient of tropical montane forests, Biotropica, in press.

Nadkarni, N. M., Schaefer, D., Matelson, T. J., and Solano, R.: Comparison of arboreal and terrestrial soil characteristics in a lower montane forest, Monteverde, Costa Rica, Pedobiologia, 46, 24-33, 2002.

Nadkarni, N. M., Schaefer, D., Matelson, T. J., and Solano, R.: Biomass and nutrient pools of canopy and terrestrial components in a primary and a secondary montane cloud forest, Costa Rica, Forest Ecol. Manag., 198, 223-236, 2004.

Pahan, I.: Panduan lengkap kelapa sawit [translation: Complete guide to oil palm], Penebar Swadaya, Jakarta, Indonesia, 2010.

R Development Core Team: R: A language and environment for statistical computing, $\mathrm{R}$ Foundation for Statistical Computing, Vienna, Austria., 2015.

Roy, R. and Conrad, R.: Effect of methanogenic precursors (acetate, hydrogen, propionate) on the suppression of methane production by nitrate in anoxic rice field soil, FEMS Microbiol. Ecol., 28, 49-61, 1999.

van Straaten, O., Corre, M. D., Wolf, K., Tchienkoua, M., Cuellar, E., Matthews, R. B., and Veldkamp, E.: Conversion of lowland tropical forests to tree cash crop plantations loses up to one-half of stored soil organic carbon, P. Natl. Acad. Sci. USA, 112, 9956-9960, 2015.

Veldkamp, E., Koehler, B., and Corre, M. D.: Indications of nitrogen-limited methane uptake in tropical forest soils, Biogeosciences, 10, 5367-5379, 2013. 
Wanek, W., Arndt, S. K., Huber, W., and Popp, M.: Nitrogen nutrition during ontogeny of hemiepiphytic Clusia species, Funct. Plant Biol., 29, 733-740, 2002.

Werner, F. A., Homeier, J., Oesker, M., and Boy, J.: Epiphytic biomass of a tropical montane forest varies with topography, J. Trop. Ecol., 28, 23-31, 2012. 


\section{Chapter 5}

\section{Synthesis}

\subsection{Key findings of this thesis}

Chapter 2: Soil fertility controls soil-atmosphere carbon dioxide and methane fluxes in a tropical landscape converted from lowland forest to rubber and oil palm plantations.

Forest conversion to smallholder oil palm plantations reduced soil carbon dioxide $\left(\mathrm{CO}_{2}\right)$ fluxes by $38-45 \%$ as a consequence of strongly decomposed soil organic matter and reduced soil carbon (C) stocks, caused by low input of litterfall and low root production. Additionally, liming and $\mathrm{P}$ fertilization might have led to a reduction in $\mathrm{C}$ allocation to roots, contributing to the observed decrease in soil $\mathrm{CO}_{2}$ fluxes. Methane $\left(\mathrm{CH}_{4}\right)$ uptake was reduced in smallholder rubber and oil palm plantations by 44-93\% compared to the reference land uses (forest and jungle rubber), which was related to decreases in nitrogen $(\mathrm{N})$ availability.

\section{Chapter 3: Soil nitrogen oxide fluxes from lowland forests converted to smallholder rubber and oil palm plantations in Sumatra, Indonesia.}

Forest conversion to smallholder rubber or oil palm plantations had no effect on soil nitrous oxide $\left(\mathrm{N}_{2} \mathrm{O}\right)$ and nitric oxide (NO) fluxes due to low initial soil $\mathrm{N}$ availability in the reference land uses and only small reductions in $\mathrm{N}$ availability with land-use change. Hence, changes in $\mathrm{N}$-oxide fluxes, which are primarily controlled by soil $\mathrm{N}$ availability, were too small to detect.

\section{Chapter 4: Canopy soil of oil palm plantations emits methane and nitrous oxide.}

Oil palm canopy soil was a source of $\mathrm{N}_{2} \mathrm{O}$ and $\mathrm{CH}_{4}$; moisture content as well as soil $\mathrm{N}$ availability controlled these greenhouse gas fluxes. Nevertheless, the contributions of oil palm canopy soil greenhouse gas fluxes to total soil fluxes (canopy soil + ground soil) were low due to the low mass of canopy soil per hectare and high amount of nitrate which might inhibit $\mathrm{CH}_{4}$ production. 


\subsection{Implications for the carbon budget}

Combining the data on soil $\mathrm{CO}_{2}$ fluxes from different land uses in Jambi Province, Sumatra, Indonesia, with ancillary data on soil organic C (SOC) stocks (van Straaten et al., 2015), above- and belowground tree biomass (AGB and BGB) and net primary production (NPP) (Kotowska et al., 2015) measured in the same study region, gives a more comprehensive picture of $\mathrm{C}$ dynamics with land-use change. In particular, this approach enables us to estimate decreases in total $\mathrm{C}$ stocks with conversion of lowland rainforest to rubber and oil palm plantations and to estimate the net biome exchange (NBE) for the three different land uses in the two landscapes (clay and loam Acrisol). Thereby the NBE denotes the net sequestration of $\mathrm{C}$ in an ecosystem on an annual basis (NPP minus heterotrophic soil respiration and harvest; Kirschbaum et al. 2001). Only the major fluxes of $\mathrm{CO}_{2}$ uptake by plants (commonly expressed as $\mathrm{NPP}$ ), $\mathrm{CO}_{2}$ release during soil respiration and harvest losses are considered in the following NBE estimation (Fig. 5.2a-c). Other minor $\mathrm{C}$ inputs and outputs into forests and tree plantations which we present in the present thesis, i.e., $\mathrm{CH}_{4}$ oxidation in soils and emissions of $\mathrm{CH}_{4}$ from oil palm canopy soils are negligible (Fig. 5.2a-c).

Focusing first on C stock losses, Kotowska et al. (2015) showed that the biggest changes in $\mathrm{C}$ stocks with conversion of rainforest into tree plantations were observed from the AGB and BGB (Fig. 5.2a-c). Conversion of forest to oil palm reduced the AGB and BGB by $85-87 \%$ (Fig. 5.2a, b), while the conversion into rubber caused reductions of 79-82\% (Fig. 5.2a, c) (Kotowska et al., 2015). In the top $3 \mathrm{~m}$ of soil, SOC stocks decreased by much a lower extent (van Straaten et al., 2015): by $7 \%$ in oil palm (Fig. 5.2a, b) and $4 \%$ in rubber (Fig. 5.2a, c) (van Straaten et al., 2015). However, the majority of soil losses occurred in the top $10 \mathrm{~cm}$, representing $39 \%$ (oil palm) and $22 \%$ (rubber) of the initial C from this top layer (van Straaten et al., 2015). In accordance with these results, soil $\mathrm{CO}_{2}$ fluxes in oil palm also decreased (Fig. 5.2a, b), illustrating that changes within both tree biomass and soil $\mathrm{C}$ stocks influenced soil $\mathrm{CO}_{2}$ fluxes (Hassler et al., 2015). Nevertheless we could not detect any changes in soil $\mathrm{CO}_{2}$ fluxes in rubber plantations (Fig. 5.2a, c) (Hassler et al., 2015), probably because leaf litterfall was still higher compared to zero input in oil palm (into the inter-rows, where we measured our soil $\mathrm{CO}_{2}$ fluxes). Taken together, the system lost a total of $169.3 \pm 21.2 \mathrm{Mg} \mathrm{C} \mathrm{ha}^{-1}$ in the clay Acrisol and 194.4 $\pm 15.0 \mathrm{Mg} \mathrm{C} \mathrm{ha}^{-1}$ in the loam Acrisol (reductions in AGB and BGB plus the 
reductions in SOC) with conversion of forest to oil palm plantations (Fig. 5.2a, b). Conversion of forest to rubber plantations caused a total loss of $153.0 \pm 24.2 \mathrm{Mg} \mathrm{C} \mathrm{ha}^{-1}$ in the clay Acrisol and 175.2 \pm 7.5 $\mathrm{Mg} \mathrm{C} \mathrm{ha}^{-1}$ in the loam Acrisol (Fig. 5.2a, c).

Using the NPP of oil palm and forest, and considering yield export and heterotrophic soil respiration losses (assuming a proportion of heterotrophic soil respiration of $30 \%$ for oil palm; Lamade et al., 1996 and $64 \%$ for forest; Fujii et al., 2009) $)^{1,2}$, the NBE of oil palm plantations is 2-4.5 times higher than the natural forest (significantly different only in the loam Acrisol; $P=$ 0.01-0.21) (Fig. 5.2a, b). This might seem surprising, since around 56-66\% of oil palm's NPP was attributed to fruits, which leave the system via harvest (Fig. 5.2b) (Kotowska et al., 2015). However, the relatively high $\mathrm{NBE}$ in oil palm can be explained by the lower annual soil $\mathrm{CO}_{2}$ emissions and lower estimation of heterotrophic soil respiration to total soil respiration in oil palm, influencing the NBE calculation (30\% in oil palm versus $64 \%$ in forest). Although the NBE of oil palm plantations is higher compared to forest, the conversion into oil palm has negative implications for climate change. The forest conversion itself results in a huge $\mathrm{C}$ loss, by reducing tree biomass as well as SOC stocks (see above). This loss is in magnitude 80-90 times higher compared to the difference in NBE between oil palm plantations and forests. Even by assuming a constant NBE over time in oil palm, C stock losses due to forest conversion cannot be compensated with time. Oil palm plantations get cut down latest 25 years after cultivation (Curley and Tinker, 2003) while they would need at least 50-70 years to sequester the lost C. Taking into account the NPP of rubber as well as harvest and heterotrophic respiration losses (assuming a proportion of heterotrophic soil respiration of $37 \%$ for rubber; Satakhun et al., 2013) $)^{3}$, rubber plantations are small annual $C$ sources in both landscapes (though not significantly different than forest; $P=0.10-0.36$ ) (Fig. 5.2a, c). Consequently conversion of forest to rubber plantation has a negative impact on climate change due to the losses in $\mathrm{C}$ stocks with conversion (see above) and due to the negative NBE.

\footnotetext{
${ }^{1}$ Study from Benin on Ferralsol soils, used as no study was found on lowland mineral soils from Indonesia reporting the proportion of heterotrophic soil respiration to total soil respiration in oil palm plantations

${ }^{2}$ Study from Indonesia on Acrisol soils, reporting the proportion of heterotrophic soil respiration to total soil respiration in lowland forests

${ }^{3}$ Study from Thailand on Ferralsol soils, used as no study was found on lowland mineral soils from Indonesia reporting the proportion of heterotrophic soil respiration to total soil respiration in rubber plantations
} 
For all three land uses, it should be mentioned that root exudates and $\mathrm{C}$ export to mycorrhizae are not measured in the study by Kotowska et al. (2015), therefore leading to an underestimation of the NPP (in temperate forest ecosystems they can account for 3-15\% of NPP; Girardin et al., 2010). Additionally, soil $\mathrm{CO}_{2}$ emissions from the frond-stacked areas in oil palm plantations are not considered in the study by Hassler et al. (2015) (soil $\mathrm{CO}_{2}$ emissions from fertilized areas were considered in the NBE estimation). Previous studies have shown that soil $\mathrm{CO}_{2}$ fluxes under those fronds can be approximately three-fold higher than in the inter-row areas (Goodrick et al., 2016). These aspects might mainly underestimate forest's NBE and slightly overestimating oil palm plantation's NBE.

In summary, the conversion of forest to rubber and oil palm plantations has a negative effect on $\mathrm{C}$ stocks and annual $\mathrm{C}$ budgets. $\mathrm{C}$ stocks are strongly reduced in both tree plantation systems and rubber plantations are small annual C sources. 
a) Lowland forest

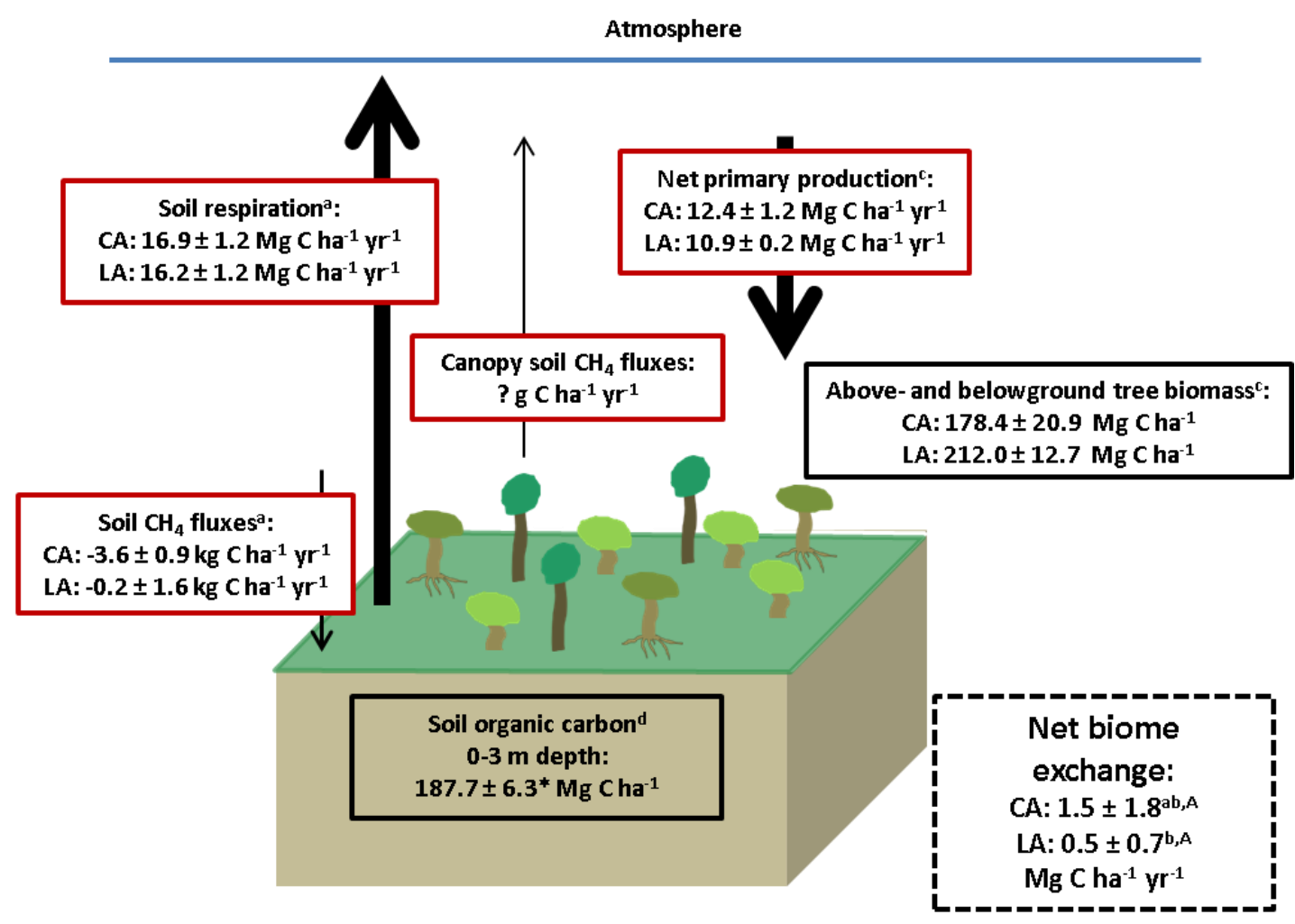

b) Oil palm plantation

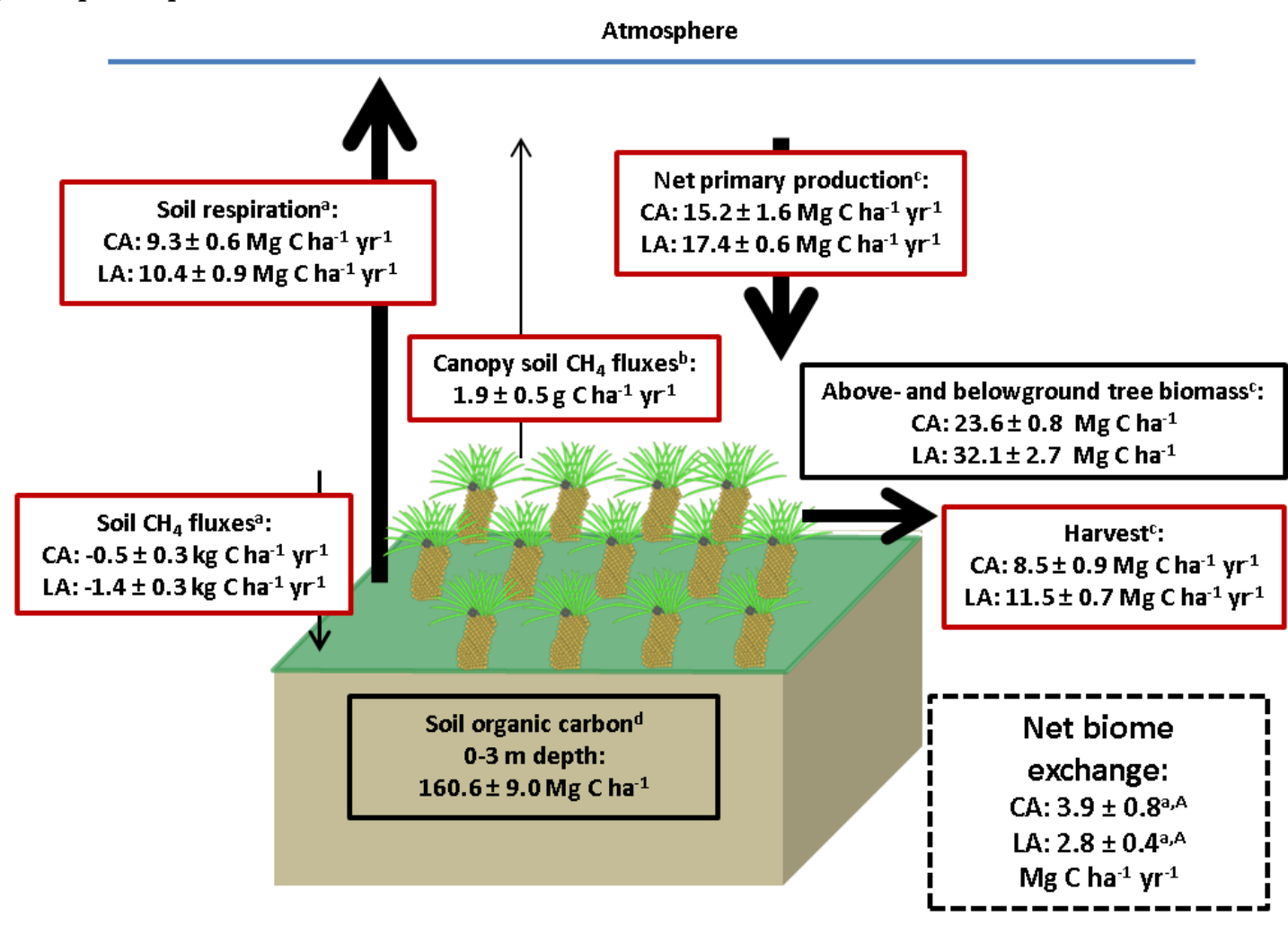




\section{c) Rubber plantation}

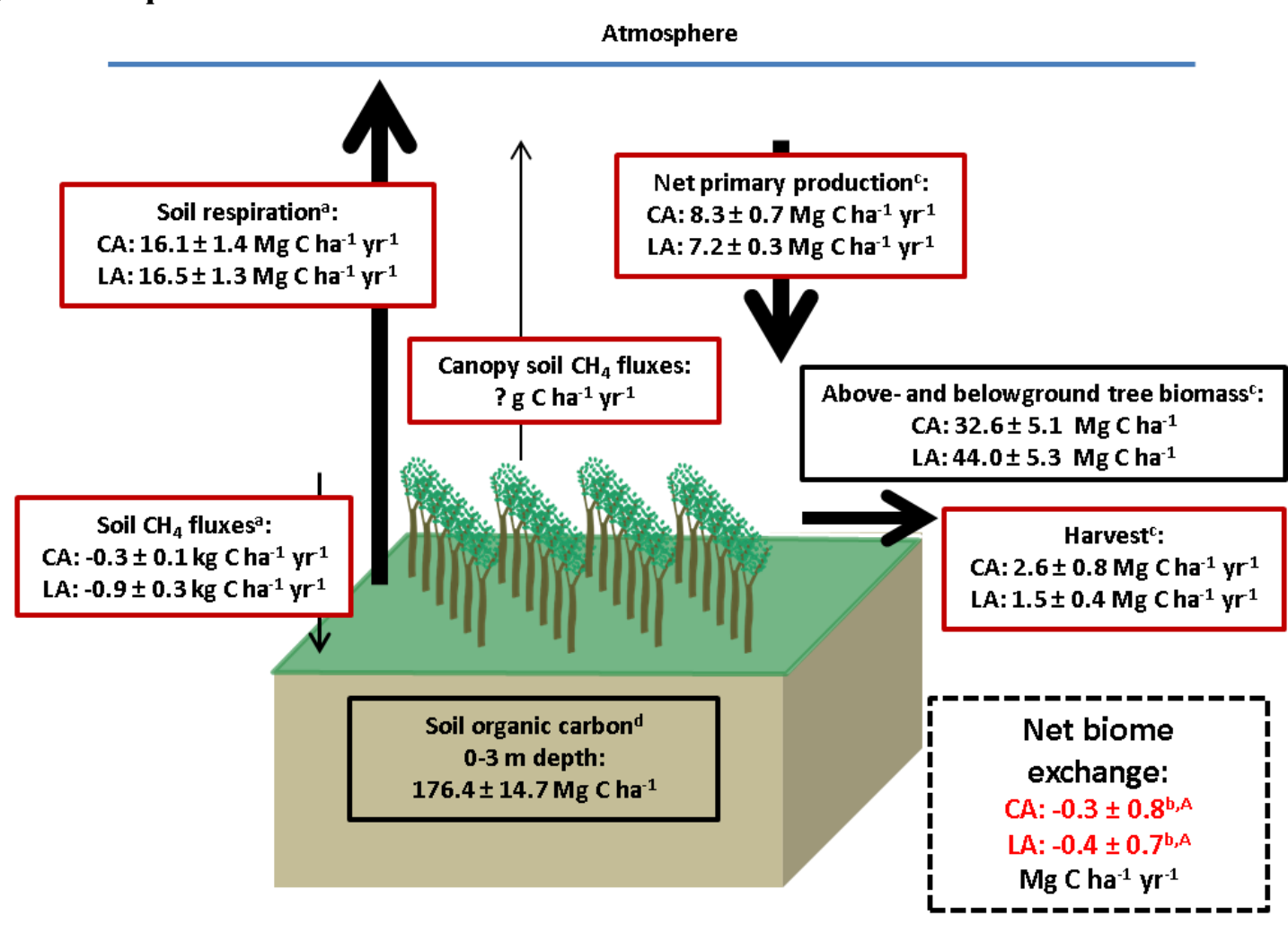

Figure 5.2. Net biome exchange, carbon $(C)$ inputs and outputs as well as $C$ stocks for forest (a), oil palm (b) and rubber (c) of the clay Acrisol (CA) and loam Acrisol (LA) landscape in Jambi, Indonesia. Minor fluxes are included if determined in the present thesis, whereby canopy soil $\mathrm{CH}_{4}$ fluxes have never been measured in tropical lowland forests or rubber plantations and are indicated with a question mark. Means (SE, $n=4$ ) followed by different lowercase letters indicate significant differences among land uses within each landscape and different capital letters indicate significant differences between landscapes within each land use (linear mixed-effect models with Fisher's LSD test at $P \leq 0.05$ ).

${ }^{\mathrm{a}}$ Hassler et al. (2015), ${ }^{\mathrm{b}}$ present thesis (see Chapter 4), ${ }^{\mathrm{c}}$ Kotowska et al. (2015), ${ }^{\mathrm{d}}$ van Straaten et al. (2015)

*Note that since the study by van Straaten et al. (2015) took place at a different study location in Jambi Province, those measurements of SOC stocks among land uses do not specifically apply to one of the two landscapes in this study. Also, van Straaten et al. (2015) considered only the soil depth with significant soil organic carbon (SOC) changes and therefor SOC losses in this figure differ to them mentioned in the text. 


\subsection{Implications for the nitrogen budget}

For this second part of my synthesis data on (canopy) soil $\mathrm{N}$-oxide fluxes are placed in a broader context and combined with data on soil N stocks (Allen et al., 2016), above- and belowground tree $\mathrm{N}^{4}$ (Kotowska et al., unpublished data; Pransiska et al., 2016), N leaching losses (Kurniawan, 2016), harvest N (Kotowska et al., 2016; Kotowska et al., unpublished data), bulk precipitation N (Kurniawan, 2016), and fertilizer N (Kurniawan, 2016). The specific aim is to determine total changes in $\mathrm{N}$ stocks with land use change, to illuminate the most important $\mathrm{N}$ inputs and outputs and to calculate an annual $\mathrm{N}$ budget for the three different land uses (Fig. 5.3a-c). However, since data availability in our study region is limited not all possible $\mathrm{N}$ inputs and outputs are included in the $\mathrm{N}$ budget calculation and hence an annual partial $\mathrm{N}$ budget is presented here.

Focusing first on changes in N stocks, Allen et al. (2016) showed that land-use change did not affect total soil $\mathrm{N}$ contents in the top 1-m depth (Fig. 5.3a-c), which was probably related to large variations among replicate plots (Allen et al., 2016). However, N stored in AGB and BGB were reduced by $80-85 \%$ in oil palm and by $70-80 \%$ in rubber (Fig. 5.3a-c ) (Kotowska et al., unpublished data; Pransiska et al., 2016). The changes in tree biomass $\mathrm{N}$ stocks were also measureable through reduced $\mathrm{N}$ return via leaf litterfall in rubber, but not in oil palm (Kotowska et al., 2016). However, these changes were not reflected in the measured $\mathrm{N}_{2} \mathrm{O}$ and $\mathrm{NO}$ fluxes among land uses (Fig. 5.3a-c) (Hassler et al., 2016). N-oxide losses were small and comparable among land uses in both landscapes which we relate to generally low $\mathrm{N}$ availability in these soils (Hassler et al., 2016). In addition to losses via $\mathrm{N}_{2} \mathrm{O}$ and $\mathrm{NO}$, a significant amount of $\mathrm{N}$ might have been lost in other gaseous forms. Probably $\mathrm{N}_{2}$ were released in these relatively moist environments (mean WFPS: 59-74\%, Hassler et al., 2015) and also losses of ammonia in fertilized oil palm plantations with application of urea are possible (Matthews, 1994). Oil palm canopy soil $\mathrm{N}_{2} \mathrm{O}$ losses were negligible in terms of $\mathrm{N}$ budget calculations, representing 100 times lower $\mathrm{N}_{2} \mathrm{O}$ fluxes compared to ground soil fluxes (Fig. 5.3b) (present thesis, see Chapter 4). Leaching losses were in comparison to gaseous losses $\left(\mathrm{N}_{2} \mathrm{O}\right.$ and $\left.\mathrm{NO}\right)$ 3-14 times larger within the land uses (Fig. 5.3a-c). In turn, $\mathrm{N}$ losses via harvest in the plantations were $2-7$ times larger

\footnotetext{
${ }^{4}$ Data are very rough estimations based on $\mathrm{N}$ concentrations in wood cores (Kotowska et al., unpublished data), and in coarse root biomass (Pransiska et al., 2016), extrapolated with above- and belowground tree biomass (Kotowska et al., 2015).
} 
than via leaching, representing the main $\mathrm{N}$ loss (Fig. 5.3b-c). Combining these results, the annual partial $\mathrm{N}$ budget for forest in both landscapes was positive (Fig. 5.3a), and negative for oil palm and rubber, except for oil palm in the loam Acrisol landscapes (Fig. 5.3b-c). Nevertheless, it was only significantly reduced in oil palm plantations of the clay Acrisol soil $(P<0.01-0.12)$ (Fig. 5.3a-c). The positive $\mathrm{N}$ budget in oil palm of the loam Acrisol was due to higher $\mathrm{N}$ fertilizer inputs (Fig. 5.3b). The negative budgets indicate that $\mathrm{N}$ inputs via precipitation and fertilization could not compensate the huge $\mathrm{N}$ losses via harvest. However, $\mathrm{N}$ inputs and outputs such as $\mathrm{N}$ fixation (Cleveland et al., 1999), erosion (Guillaume et al., 2015) or $\mathrm{N}_{2}$ emissions (Davidson et al., 2000) which are not included in this estimate might change the annual partial $\mathrm{N}$ budget.

In summary, these annual partial $\mathrm{N}$ budgets give an indication on $\mathrm{N}$ losses and gains in the three investigated land uses. They reflect that with forest conversion, tree plantations, although partly fertilized, lose more $\mathrm{N}$ than they gain (except for the oil palm plantation in the loam Acrisol with relatively high fertilization rates). Therefore, to keep yields in rubber and oil palm plantation constant, an adjusted fertilizer management is needed. 
a) Lowland forest

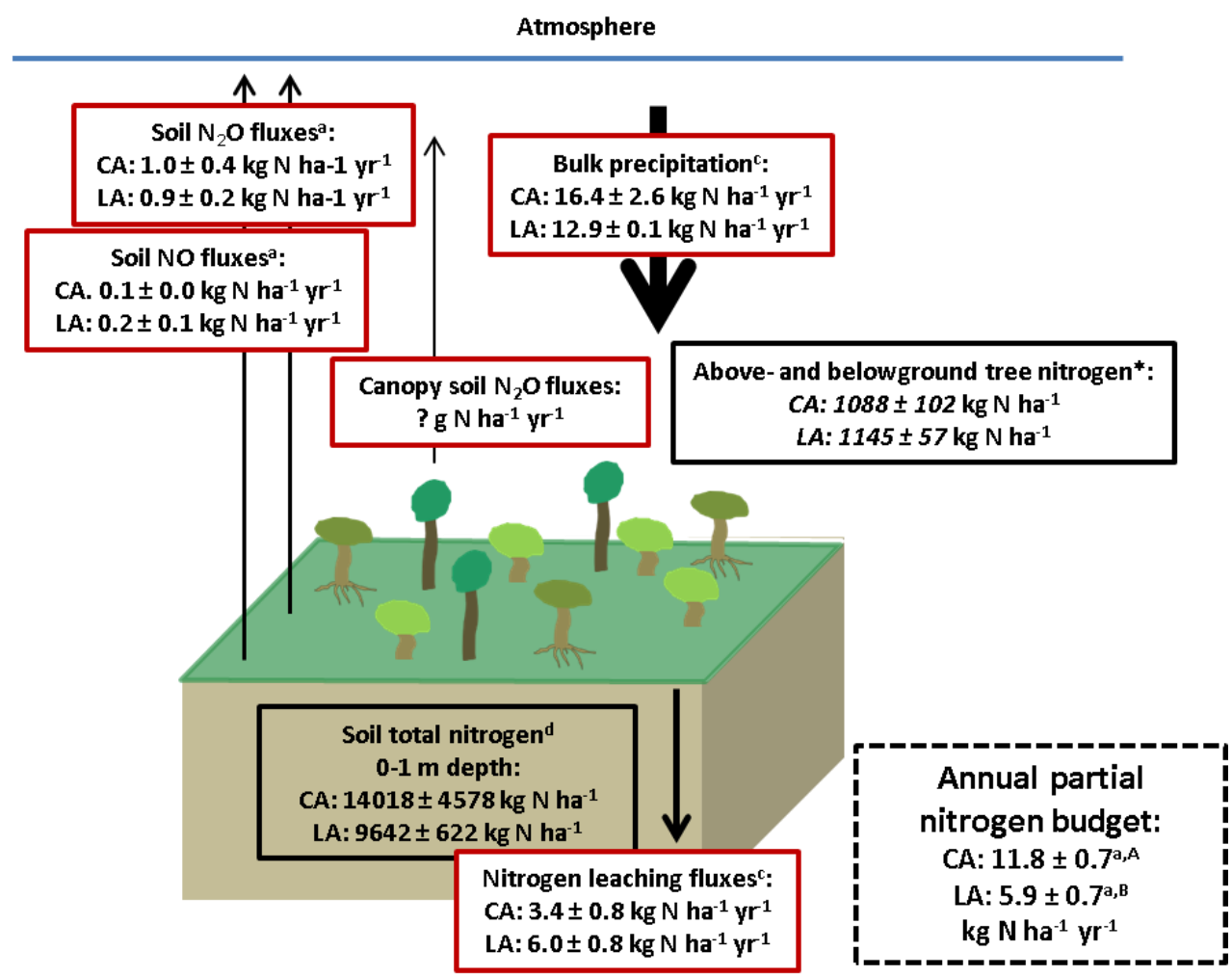

b) Oil palm plantation

Atmosphere

\section{$\uparrow \uparrow$}

Soil $\mathrm{N}_{2} \mathrm{O}$ fluxes

CA: $1.2 \pm 0.3 \mathrm{~kg} \mathrm{~N}$ ha-1 $\mathrm{yr}^{1}$

LA: $1.3 \pm 0.7$ kg N ha-1 $\mathrm{yr}^{1}$

Soil NO fluxes ${ }^{\mathrm{a}}$ :

CA. $0.1 \pm 0.1 \mathrm{~kg} \mathrm{~N} \mathrm{ha}^{-1} \mathrm{yr}^{1}$

LA: $0.2 \pm 0.1 \mathrm{~kg} \mathrm{~N} \mathrm{ha}^{-1} \mathrm{yr}^{1}$

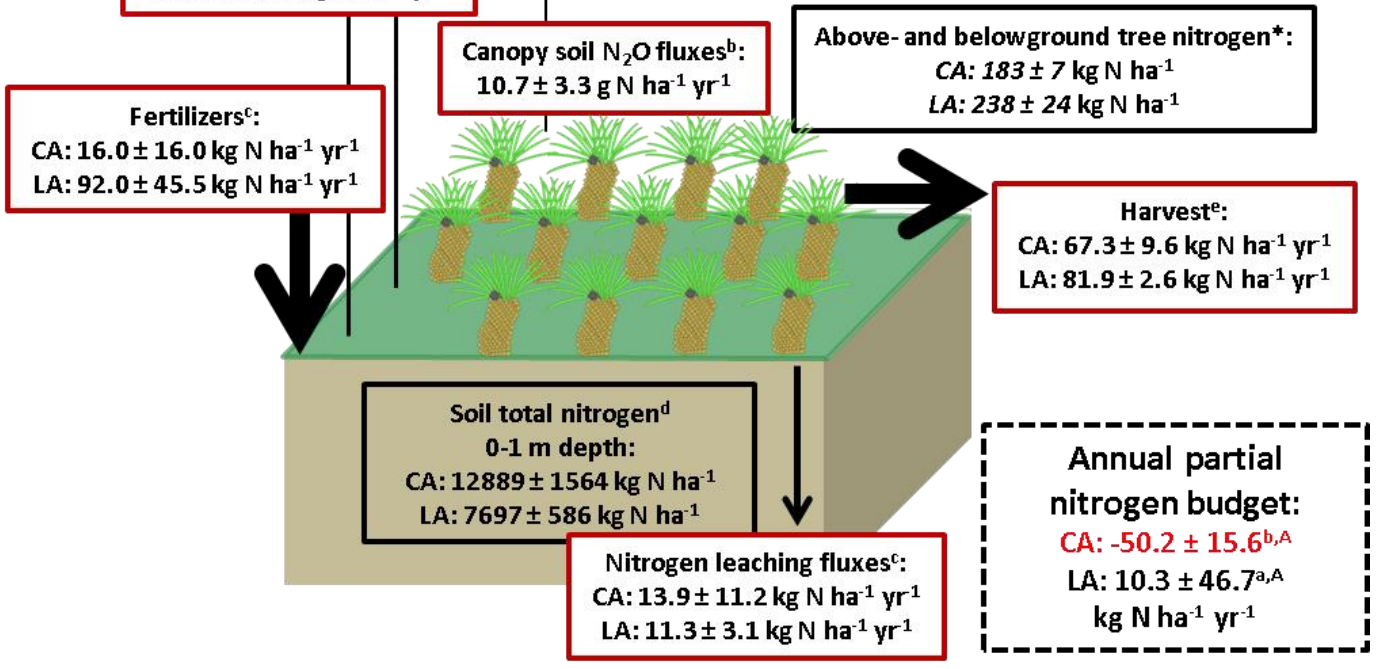




\section{c) Rubber plantation}

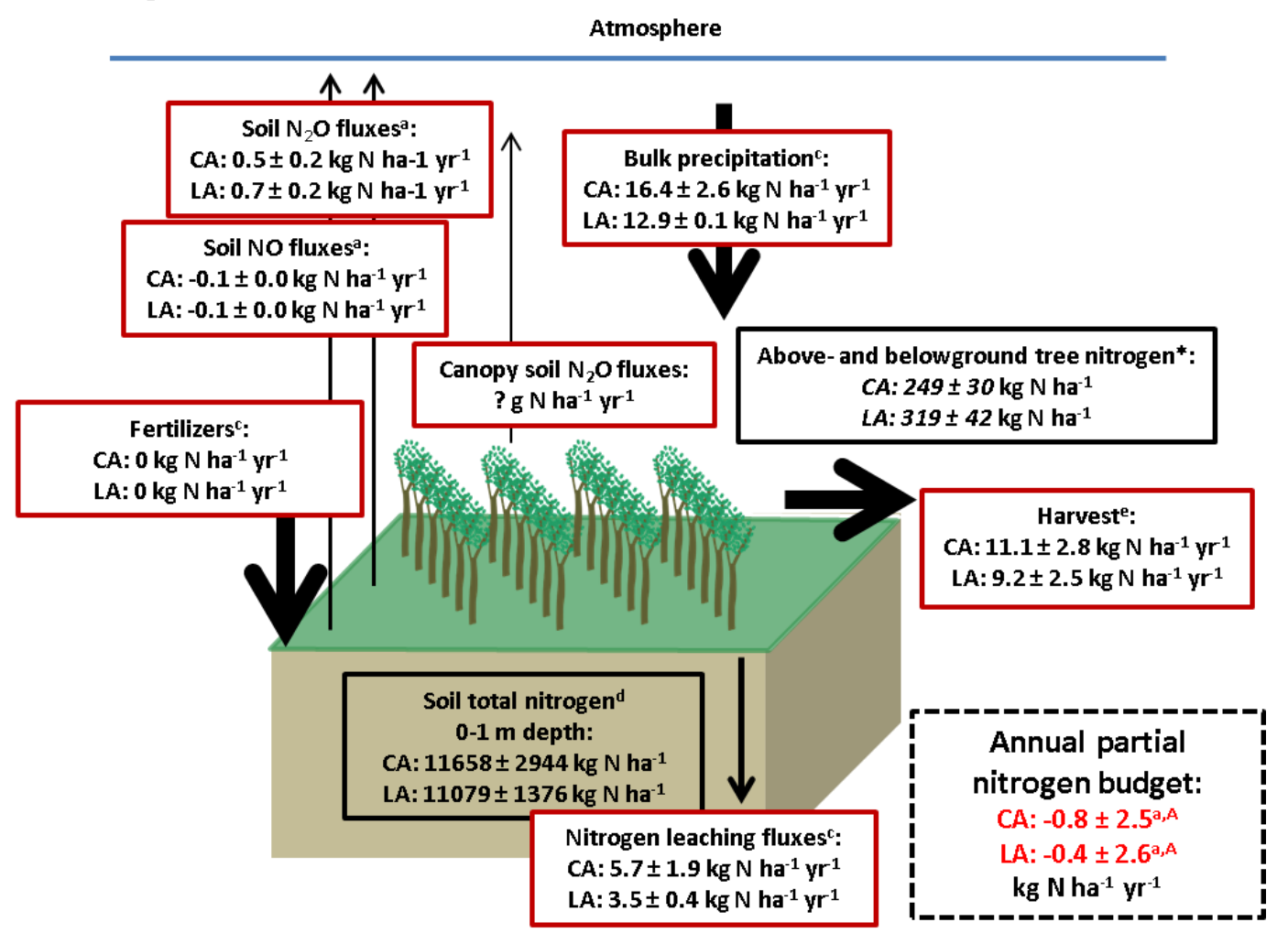

Figure 5.3. Annual partial nitrogen $(\mathrm{N})$ budget, $\mathrm{N}$ inputs and outputs as well as $\mathrm{N}$ stocks for forest (a), oil palm (b) and rubber (c) of the clay Acrisol (CA) and loam Acrisol (LA) landscape in Jambi, Indonesia. Canopy soil $\mathrm{N}_{2} \mathrm{O}$ fluxes have never been measured in tropical lowland forests or rubber plantations and are indicated with a question mark. Means (SE, $n=4$, except oil palm $n=3$ ) followed by different lowercase letters indicate significant differences among land uses within each landscape and different capital letters indicate significant differences between landscapes within each land use (linear mixedeffect models with Fisher's LSD test at $P \leq 0.05$ ).

${ }^{\mathrm{a}}$ Hassler et al. (2016), ${ }^{\mathrm{b}}$ present thesis (see Chapter 4), ${ }^{\mathrm{c}}$ Kurniawan (2016), ${ }^{\mathrm{d}}$ Allen et al. (2016), ${ }^{\mathrm{e}}$ Kotowska et al. (2016); Kotowska et al. (unpublished data).

*Data are only rough estimations based on $\mathrm{N}$ concentrations in wood cores (Kotowska et al., unpublished data), and in coarse root biomass (Pransiska et al., 2016), extrapolated with above- and belowground tree biomass (Kotowska et al., 2015). 


\section{References}

Allen, K., Corre, M. D., Kurniawan, S., Utami, S. R., and Veldkamp E.: Spatial variability surpasses land-use change effects on soil biochemical properties of converted lowland landscapes in Sumatra, Indonesia, Geoderma, 284, 42-50, 2016.

Cleveland, C. C., Townsend, A. R., Schimel, D. S., Fisher, H., Howarth, R. W., Hedin, L. O., Perakis, S. S., Latty, E. F., von Fischer, J. C., Elseroad, A., and Wasson, M. F.: Global patterns of terrestrial biological nitrogen $\left(\mathrm{N}_{2}\right)$ fixation in natural ecosystems, Global Biogeochem. Cy., 13, 623-645, 1999.

Curley,R. H. V. and Tinker, P. B.: The oil palm, Blackwell Science Ltd., Oxford, UK, Iowa, USA, Victoria, Australia, 2003.

Davidson, E. A., Keller, M., Erickson, H. E., Verchot, L. V., and Veldkamp, E.: Testing a conceptual model of soil emissions of nitrous and nitric oxides, Bioscience, 50, 667-680, 2000.

Fujii, K., Uemura, M., Hayakawa, C., Funakawa, S., Sukartiningsih, Kosaki, T., and Ohta, S.: Fluxes of dissolved organic carbon in two tropical forest ecosystems of East Kalimantan, Indonesia, Geoderma, 152, 127-136, 2009.

Girardin, C. A. J., Malhi, Y., Aragao, L. E. O. C., Mamani, M., Huaraca Huasco, W., Durand, L., Feeley, K. J., Rapp, J., Silva-Espejo, J. E., Silman, M., Salinas, N., and Whittaker, R. J.: Net primary productivity allocation and cycling of carbon along a tropical forest elevational transect in the Peruvian Andes, Glob. Change Biol., 16, 3176-3192, 2010.

Goodrick, I., Nelson, P. N., Nake, S., Webb, M. J., Bird, M. I. and, Huth, N.: Tree-scale spatial variability of soil carbon cycling in a mature oil palm plantation, Soil Research, 54, 397-406, 2016.

Guillaume, T., Damris, M. and Kuzyakov, Y.: Losses of soil carbon by converting tropical forest to plantations: Erosion and decomposition estimated by $\delta{ }^{13} \mathrm{C}$, Glob. Change Biol., 21, 35483560, 2015.

Hassler, E., Corre, M. D., Tjoa, A., Damris, M., Utami, S. R., and Veldkamp, E.: Soil fertility controls soil-atmosphere carbon dioxide and methane fluxes in a tropical landscape converted 
from lowland forest to rubber and oil palm plantations, Biogeosciences, 12, 5831-5852, 2015.

Hassler, E., Corre, M. D., Kurniawan, S., and Veldkamp, E.: Soil nitrogen oxide fluxes from lowland forests converted to smallholder rubber and oil palm plantations in Sumatra, Indonesia, Biogeosciences Discuss., in review, 2016.

Kirschbaum, M. U. F., Eamus, D., Gifford, R. M., Roxburgh, S. H., and Sands, P, J.: Definitions of some ecological terms commonly used in carbon accounting, NEE Workshop Proceedings, 1$5,2001$.

Kotowska, M. M., Leuschner, C., Triadiati, T., Meriem, S., and Hertel, D.: Quantifying above and belowground biomass carbon loss with forest conversion in tropical lowlands of Sumatra (Indonesia), Glob. Change Biol., 21, 3620-3634, 2015.

Kotowska, M. M., Leuschner, C., Triadiati, T., and Hertel, D.: Conversion of tropical lowland forest reduces nutrient return through litterfall, and alters nutrient use efficiency and seasonality of net primary production, Oecologia, 180, 601-618, 2016.

Kurniawan, S.: Conversion of lowland forests to rubber and oil palm plantations changes nutrient leaching and nutrient retention efficiency in highly weathered soils of Sumatra, Indonesia (Doctoral dissertation, Faculty of Forest Sciences and Forest Ecology, Georg-August University of Goettingen), available at: http://hdl.handle.net/11858/00-1735-0000-0028-8706-8 (last access: 25.05.2016), 2016.

Lamade, E., Djegui, N., and Leterme, P.: Estimation of carbon allocation to the roots from soil respiration measurements of oil palm, Plant Soil, 181, 329-339, 1996.

Matthews, E.: Nitrogenous fertilizers: global distribution of consumption and associated emissions of nitrous oxide and ammonia, Global Biogeochem. Cy., 8, 411-439, 1994.

Pransiska, Y., Triadiati, T., Tjitrosoedirjo, S., Hertel, D., and Kotowska, M. M.: Forest conversion impacts on the fine and coarse root system, and soil organic matter in tropical lowlands of Sumatera (Indonesia), Forest Ecol. Manag., 379, 288-298, 2016.

Satakhun, D., Gay, F., Chairungsee, N., Kasemsap, P., Chantuma, P., Thanisawanyangkura, S., Thaler, P., and Epron, D.: Soil $\mathrm{CO}_{2}$ efflux and soil carbon balance of a tropical rubber plantation, 
Ecol. Res., 28, 969-979, 2013.

van Straaten, O., Corre, M. D., Wolf, K., Tchienkoua, M., Cuellar, E., Matthews, R. B., and Veldkamp, E.: Conversion of lowland tropical forests to tree cash crop plantations loses up to one-half of stored soil organic carbon, P. Natl. Acad. Sci. USA, 112, 9956-9960, 2015. 


\section{Danksagung}

An erster Stelle gebührt mein Dank meinen Betreuern Professor Dr. Edzo Veldkamp und Dr. Marife D. Corre, die mich während meiner gesamten Promotionszeit unterstützt haben und bei denen ich gelernt habe, was wissenschaftliches Arbeiten und Schreiben überhaupt bedeutet.

Weiterhin danke ich der DFG, die meine Stelle im Rahmen des SFB 990: Ökologische und sozioökonomische Funktionen tropischer Tieflandregenwaldtransformationssysteme (Sumatra, Indonesien) finanziert und meine Promotion damit erst ermöglicht hat.

Für die Unterstützung in Indonesien danke ich meinen Counterparts Dr. Aiyen Tjoa, Dr. Sri Rahayu Utami sowie Dr. M. Damris, meinen Assistenten im Feld Eduard, Nelson, Edi, Ozy und Ardi und den Mitarbeitern im Jambi-Büro Mega, Rizky, Yuking und Ozy.

Ein großer Dank geht auch an alle KollegInnen in unserer Arbeitsgruppe, die nicht nur bei fachlichen Fragen ein offenes Ohr hatten, sondern immer auch aufmunternd und hilfsbereit waren und mit denen ich viel lachen konnte: Syahrul, Kara, Amanda, Oliver, Anke, Marcus, Leonie, Yuan, Angelica, Dirk, Andrea, Kerstin und Martina.

Meinen KollegInnen im SFB danke ich für die tolle gemeinsame Zeit in Indonesien und für ihren fachlichen Input: Martyna, Ana, Josi, Natalie, Katja, Barbara, Martin, Lisa, Anne, Mimi, Judith, Alex, Thomas, Nicole und Siria.

Bedanken möchte ich mich auch bei meinen Schwestern Eileen, Ellen und Jane, die einfach immer da waren, während aller Höhen und Tiefen, genauso wie meinem Vater für das inhaltliche Interesse an meiner Arbeit und meiner Mutter dafür, dass sie stolz darauf ist, dass ich promoviere.

Im Besonderen danke ich meinem Mann Markus, der zu jeder Phase meiner Dissertation an meiner Seite stand, mich oft in Indonesien besucht hat und mich auch auf den von Rattandornen und Sümpfen gepflasterten Wegen zu den Regenwaldplots begleitet hat. Der sich von Blutegeln hat piesacken lassen, aber auch das Haus in der Gotong Royong gehütet hat, wenn ich nicht da war und der mich aufgemuntert und umarmt hat sowie immer auch Interesse an meiner inhaltlichen Arbeit hatte. Auch meinem Sohn Bruno danke ich dafür, dass er mir während der Zeit des Schreibens mein Leben mit seinem Lachen versüßt hat.

$\mathrm{Zu}$ allerletzt danke ich auch meinen Freunden Silke und Anna, die zur gleichen Zeit wie ich ihre Dissertation schreiben und mich damit auf diesem Weg begleitet haben. 


\section{Curriculum Vitae}

Evelyn Hassler

Date of birth: May 18, 1984

Gender: Female

Nationality: German

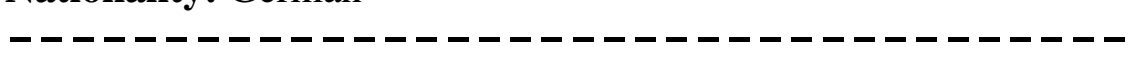

\section{Education}

since $03 / 2012$

$\mathrm{PhD}$ candidate within the Group of Soil Science of Tropical and

Subtropical Ecosystems at the University of Göttingen, Germany

$11 / 2010$

Diploma in Geography (Physical Geography) at the University of

Marburg, Germany

Minor subjects: Soil Science, Peace and Conflict Studies, Political Science

2009

Master Thesis within the Group of Plant Nutrition at the ETH-Zurich, Switzerland

Thesis: The influence of drying and rewetting processes of a Ferralsol on the phosphorus uptake of maize (Zea mays L.)

2003

Abitur, Kippenberg Grammar School, Bremen, Germany

\section{Publications}

Hassler, E., Corre, M. D., Tjoa, A., Damris, M., Utami, S. R., Veldkamp, E: Soil fertility controls soil-atmosphere carbon dioxide and methane fluxes in a tropical landscape converted from lowland forest to rubber and oil palm plantations, Biogeosciences, 12, 5831-5852, 2015.

Hassler, E., Corre, M. D., Kurniawan, S., and Veldkamp, E.: Soil nitrogen oxide fluxes from lowland forests converted to smallholder rubber and oil palm plantations in Sumatra, Indonesia, Biogeosciences Discuss., in review, 2016.

Hassler, E., Allen, K., Corre, M. D., Kurniawan, S., Veldkamp, E: Canopy soil of oil palm plantations emits methane and nitrous oxide, In prep. 


\section{Talks and poster presentations}

Hassler, E., Corre, M. D., Veldkamp, E.: Fertilizer-induced soil $\mathrm{N}_{2} \mathrm{O}$ and $\mathrm{NO}$ fluxes from smallholder oil palm plantations following deforestation in Sumatra, Indonesia, European Conference of Tropical Ecology, 23-26 February 2016, Göttingen, Germany, 2016. Oral presentation

Hassler, E., Corre, M. D., Tjoa, A., Damris, M., Utami, S. R., Veldkamp, E.: Soil fertility controls soil-atmosphere carbon dioxide and methane fluxes in a tropical landscape converted from lowland forest to rubber and oil palm plantations, GfÖ Annual Meeting 2015, Ecology for Sustainable Agriculture, 31 August-4 September 2015, Göttingen, Germany, 2015. Poster presentation

Preuß (Hassler), E., Corre, M. D., Veldkamp, E.: Soil carbon dioxide and methane fluxes from lowland forests converted to oil palm and rubber plantations in Sumatra, Indonesia, Biogeomon conference, $8^{\text {th }}$ International Symposium on Ecosystems Behavior, 13-17 July 2014, Bayreuth, Germany, 2014. Poster presentation 